Golovics József

\title{
A migráció gazdaságtana: egy intézményi közgazdaságtani megközelítés
}


Összehasonlító és Intézményi Gazdaságtan Tanszék

Témavezető:

Rosta Miklós PhD

2019

(C) Golovics József

MINDEN JOG FENNTARTVA 


\title{
BUDAPESTI CORVINUS EGYETEM
}

Nemzetközi Kapcsolatok

Multidiszciplináris Doktori Iskola

\section{A migráció gazdaságtana: egy intézményi közgazdaságtani megközelítés}

\author{
Doktori értekezés
}

\section{Golovics József}

Budapest, 2019 



\section{TARTALOM}

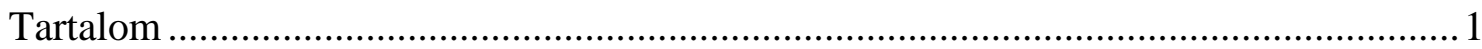

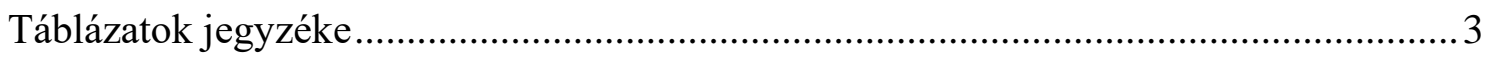

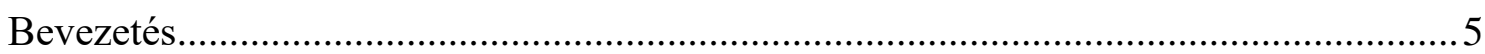

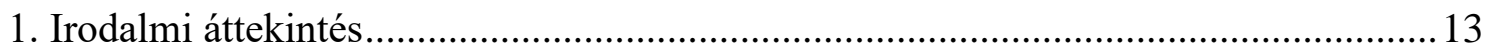

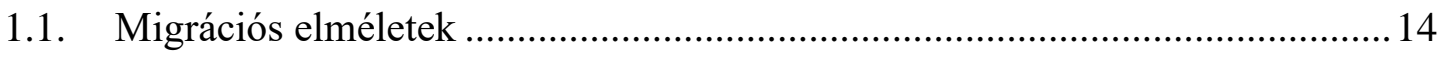

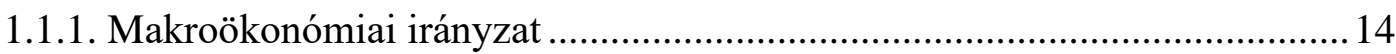

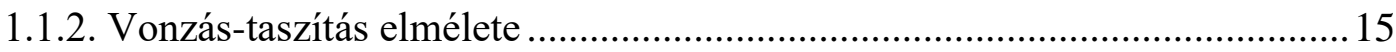

1.1.3. Mikroökonómiai humántőke elmélet ...................................................... 17

1.1.4. A mikroökonómiai modell továbblépési irányai.......................................22

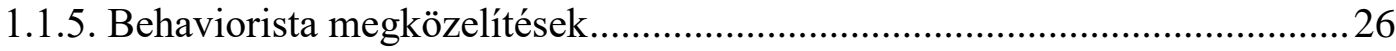

1.1.6. A migráció új közgazdaságtana ..................................................................2 29

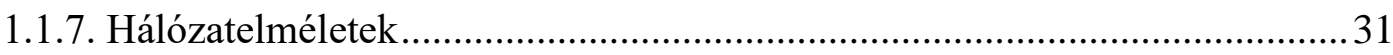

1.1.8. Intézményi jellegü megközelítések …..................................................... 33

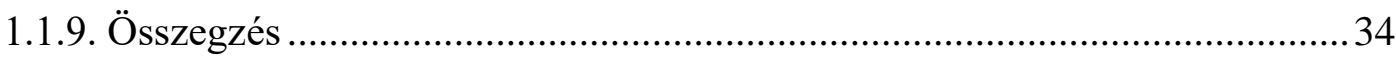

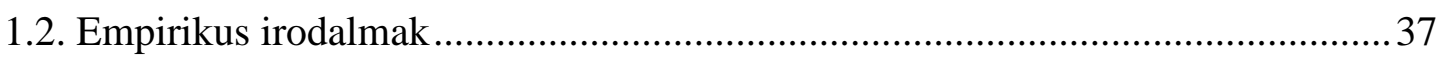

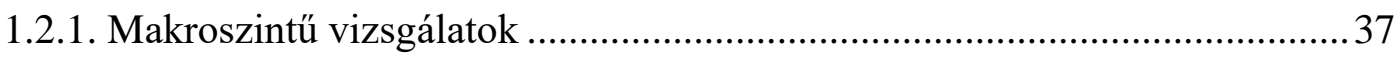

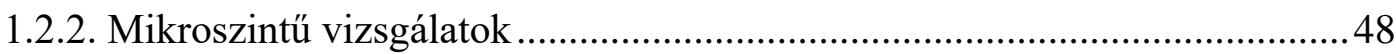

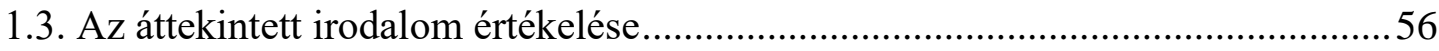

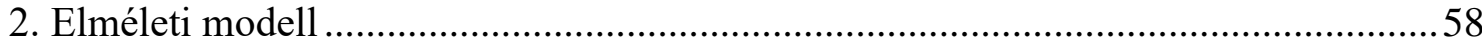

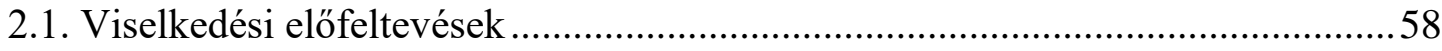

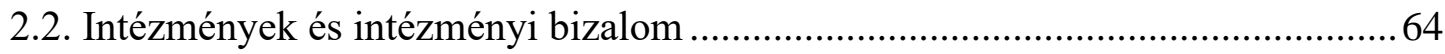

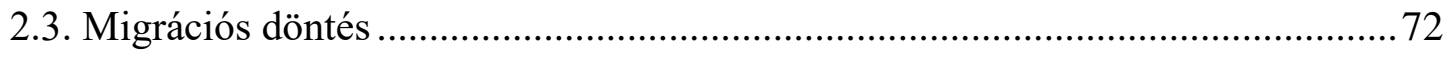

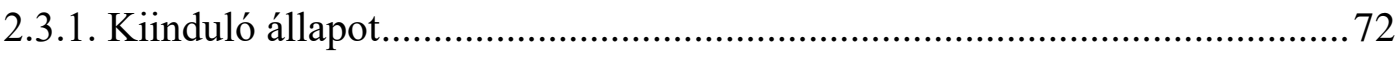

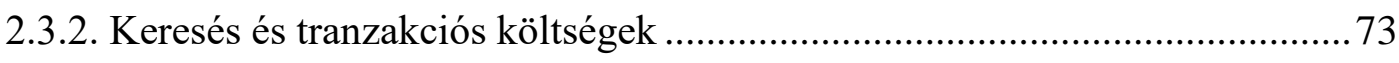

2.3.3. Döntési szempontok: standard tényezők ............................................... 80 
2.3.4. Döntési szempontok: specifikus beruházások............................................. 81

2.3.5. Döntési szempontok: lelki költségek, altruizmus, hüség ............................8 88

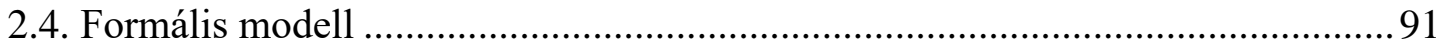

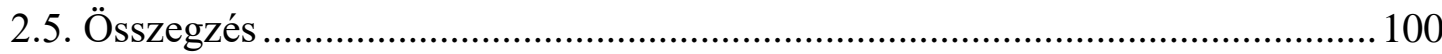

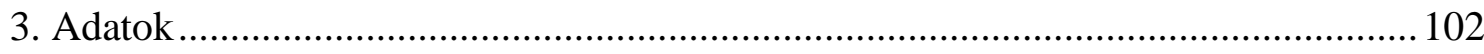

3.1. Adatokkal kapcsolatos dilemmák, kihívások ................................................. 102

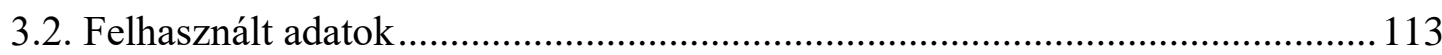

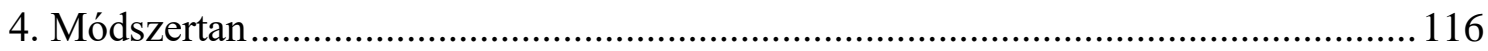

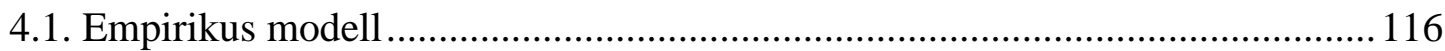

4.2. Konceptualizáció és operacionalizáció: első vizsgálat ...................................119

4.3. Konceptualizáció és operacionalizáció: második vizsgálat ............................. 125

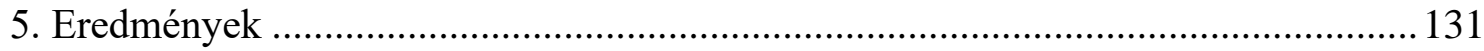

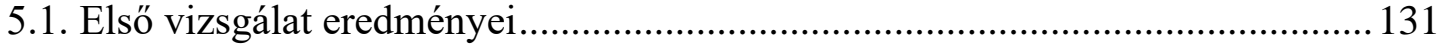

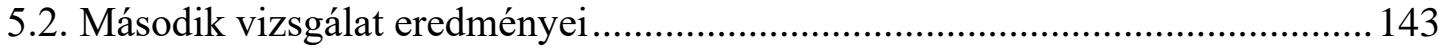

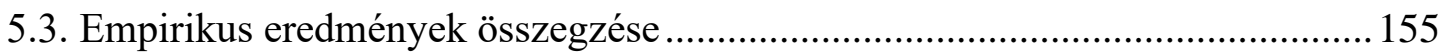

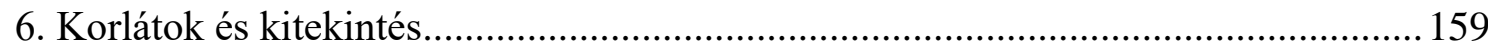

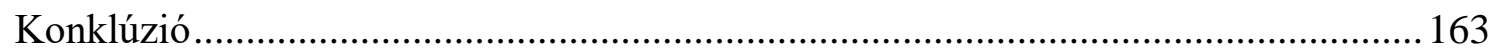

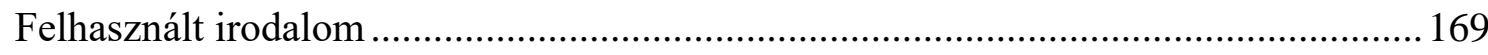

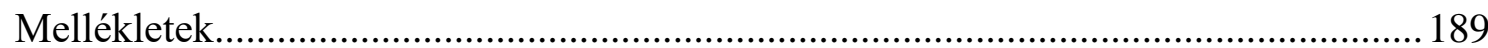

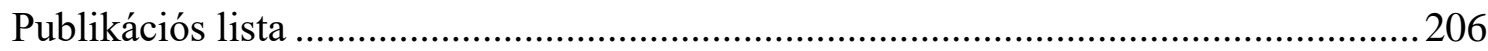




\section{TÁBLÁZATOK JEGYZÉKE}

1.1. táblázat: Migrációs elméletek: összefoglalás 36

1.2. táblázat: $A z$ 1.2.1. alfejezetben feldolgozott makroszintü irodalmak empirikus eredményeinek áttekintése. 46

1.3. táblázat: $A z$ 1.2.1. alfejezetben feldolgozott mikroszintü irodalmak empirikus eredményeinek áttekintése.

2.1. táblázat: Az elméleti modell predikciói a (13) kifejezés parciális deriváltjai alapján 100

4.1. táblázat: Az eredményváltozó képzéséhez felhasznált kérdések a 2008-as Eurobarometer felmérésböl

4.2. táblázat: Az eredményváltozó képzéséhez felhasznált kérdés a 2010-es Eurobarometer felmérésböl 126

5.1. táblázat: A migrációs hajlandóságot meghatározó tényezők az EU állampolgárai körében (2008).

5.2. táblázat: A migrációs hajlandóságot meghatározó tényezők az EU állampolgárai körében (2008). Az (II.1) specifikációjú logit modellek marginális hatásai a régi és az új tagállamok almintáján, illetve a tisztitott migrációs potenciál becslésében

5.3. táblázat: A migrációs hajlandóságot meghatározó tényezök az EU állampolgárai körében (2008). Az (II.1.1), (II.1.2) és (II.1.3) specifikációjú logit modellek marginális hatásai.

5.4. táblázat: A migrációs hajlandóságot meghatározó tényezők az EU állampolgárai körében (2010).

5.5. táblázat: A migrációs hajlandóságot meghatározó tényezök az EU állampolgárai körében (2010). A (IV) specifikációjú becslés speciális eseteinek (régi és új tagállamok mintája, tisztított migrációs potenciál), illetve a (IV.4) specifikációjú logit modell marginális hatásai.....

5.6. táblázat: A migrációs hajlandóságot meghatározó tényezők az EU állampolgárai körében (2010). A (IV) specifikációjú rendezett (ordered) logit modell együtthatói .... 154 


\section{Köszönetnyilvánítás}

Köszönöm édesanyámnak azt a közel harminc évnyi fáradozását, amely nélkül ez a disszertáció nem születhetett volna meg.

Köszönöm a gyermekeimnek, Lindának és Reginának, illetve feleségemnek, Andreának, hogy támogattak és oly sokat nélkülöztek a disszertáció megírása alatt.

Köszönöm a családom minden tagjának, akik valamilyen formában mind hozzájárultak ahhoz, hogy eljuthassak ide.

Köszönöm az Összehasonlító és Intézményi Közgazdaságtan Tanszék munkatársainak (Ádám Zoltánnak, Csaba Lászlónak, Deák Dánielnek, Gedeon Péternek, Győrffy Dórának, Hámori Balázsnak, Horváth Józsefnek, Katona Mártonnak, Medve-Bálint Gergőnek, Rosta Miklósnak, Szabó Katalinnak, Székely-Doby Andrásnak, Tóth Lászlónak, Veres Pálnak), hogy egy inspiráló munkaközösség része lehettem, amely hátteret biztosított jelen disszertáció megszületéséhez. Külön köszönet illeti Veres Pált, aki nélkül aligha váltam volna e közösség tagjává, s aki azóta is mellettem áll, továbbá témavezetőmet, Rosta Miklóst, aki folyamatosan támogatta szakmai előmenetelemet.

Kutatásom és a disszertáció megírása során sok támogatást, segítséget és javaslatot kaptam. Ezekért köszönetet mondok Benczes Istvánnak, Blahó Andrásnak, Hárs Ágnesnek, a Közösen a Jövő Munkahelyeiért Alapítványnak, Mike Károlynak, a Pallas Athéné Domus Scientiae Alapítványnak, Sik Endrének, Tétényi Andrásnak és Tőkés Lászlónak.

A disszertáció megírásához hátteret nyưjtó kutatás az Európai Unió, Magyarország és az Európai Szociális Alap társfinanszírozása által biztosított forrásból az EFOP-3.6.2-162017-00017 azonosítójú "Fenntartható, intelligens és befogadó regionális és városi modellek" címü projekt keretében jött létre. 


\section{BEVEZETÉS}

A nemzetközi migráció egy velünk élő jelenség: végigkísérte az emberiség történelmét, s jelenlegi tudásunk szerint a jövőben is a legfőbb globális kihívások között tarthatjuk majd számon (Bayer, 2019; Csaba, 2019; Szentes, 2019). Ebből fakadóan a vándorlások mozgatórugóinak és hatásainak megismerése, illetve megértése is joggal tart igényt a tudományos érdeklődésre.

A migráció globális, európai és nemzetállami szinten is komoly társadalmi, illetve gazdasági hatásokkal bír, s a következmények kapcsán az egyéni szint sem hagyható figyelmen kívül. Ezek között pozitív és negatív hatásokat egyaránt említhetünk. Mindenképpen az előbbiek között könyvelhető el, hogy az egyén lehetőségeinek spektruma bővül a migráció alternatívájával, hiszen egy jelentősen nagyobb munkaerőpiaci térben próbálhat meg boldogulni. Különösen igaz ez a migrációs közegként is egyedinek mondható Európai Unióban. A személyek szabad mozgása egyike az európai integráció alapértékeinek, ami az adminisztratív akadályok lebontása révén egy egységes munkaerőpiac létrehozását tüzte ki célul. Ez makroszinten is kedvező hatásokkal bírhat, hiszen a piac határokon átívelően, relatíve „súrlódásmentes térben” képes hatékonyan allokálni a munkaerőt. Ennek eredménye a befogadó országokban magasabb növekedési potenciálban, jobb munkaerőpiaci mutatókban, valamint a demográfiai összetétel javulásában mutatkozhatnak meg (Andor, 2014; Siposné Nándori, Dabasi-Halász, \& Illyés, 2017). A tagadhatatlan előnyök mellett azonban kihívások, veszélyek és negatív hatások is jelentkezhetnek, különösen akkor, ha az áramlások mértéke erős aszimmetriát mutat. A magasan képzett, s gyakran a kevésbé képzett munkaerő elvándorlása is komoly munkaerő-piaci kihívások elé állíthatja a kibocsájtó országokat: akár az alacsony foglalkoztatási mutatók mellett is (Fülöp, Csáfor, Nagy, \& Papanek, 2016) akut munkaerőhiány-problémák megjelenéséhez vezethet (Halász, 2018; Hárs \& Simon, 2017). Továbbá az értékes emberfők elvesztése révén romló demográfiai mutatókon túl (Hárs, 2016) fiskális veszteséget is jelent számukra (Golovics, 2015), ami nem csak az oktatás finanszírozása (Golovics, 2016a), de a nagy társadalmi elosztórendszerek jövőbeli fenntarthatósága szempontjából is aggályos lehet. Ezzel párhuzamosan a célországok számára a migráció olykor biztonsági kihívásként jelentkezhet (Tálas, 2019), s társadalmi feszültségek forrása is lehet (Bayer, 2019; Szentes, 2019). 
A hatások sokszínüsége a vándorlás okainak, mozgatórugóinak feltárását és megértését is kiemelten fontossá teszi. A migráció makroszintű neoklasszikus közgazdaságtani megközelítése a nagy átlagok szintjén jól magyarázza a vándorlások irányát és hozzávetőleges mértékét, azonban az egyes országok, s még inkább az egyén szintjén már nagyobb változatosság mutatkozik. Ennek magyarázatára a migrációkutatás más, alacsonyabb szintű elemzési egységeket használó irányzatai, így a mikroszintű neoklasszikus közgazdaságtani vagy más néven humántőke-alapú megközelítése, valamint a migráció új közgazdaságtana (Massey és mtsai., 1993) nyújthatnának segítséget. Ugyanakkor e téren is hiányosságokat találunk az irodalomban. Ebben a társadalomtudományok különböző ágai, így a szociológia (Carling \& Collins, 2018; Sik, 2001, szerk.), a pszichológia (Fawcett, 1985), vagy a kognitív- illetve viselkedéstudományok más határterületei (Carling \& Schewel, 2018; Collins, 2018) fontos adalékokkal tudtak volna szolgálni, hiszen plauzibilis leíró modelleket készítettek és impozáns eredményeket tártak fel az elvándorlást, illetve az elvándorlási kedvet alakító tényezőkről. Ezek azonban a közgazdasági elméletekbe nem, vagy csak részben - azaz nem a közgazdaságtudományi fogalomkészlet felhasználásával (Hagen-Zanker, 2008) épültek be. ${ }^{1}$

Az elméleti előrelépés szükségessége empirikus szempontból is igazolható. A migrációkutatás egyik legfontosabb „megoldandó” kérdése a helyben maradás rejtvénye. Ennek alapja, hogy a meglévő közgazdasági elméletek implikációi alapján a világ polgárainak jelentős része számára racionális döntés lenne a migráció - többségük azonban mégsem vándorol el (Borjas, 2014; Faini \& Venturini, 2010). Ez a jelenség arra világít rá, hogy több olyan, korábban figyelmen kívül hagyott vagy nem megfelelő módon hangsúlyozott tényezőnek kell lennie, amelyek érdemben befolyásolják az egyén migrációs hajlandóságot.

Jelen disszertáció az előbbi pontok mentén kíván előrelépést mutatni. Célunk egy olyan mikroszintü modell felépítése, amely közgazdasági magyarázatot ad arra, hogy mi befolyásolja az egyén migrációs hajlandóságát. E modell felvázolásakor építünk a migráció meglévő mikroszemléletü közgazdaságtanára, ám azt - felhasználva más tudományterületek empirikus eredményeit - kiegészítjük az új intézményi

\footnotetext{
1 Érdekesség, hogy a migrációkutatás egyik klasszikusának tekinthető Lee (1966) vonzás-taszítás elméletének bemutatásakor - amelyet az 1. fejezetben részletesen is ismertetünk - szintén hasonlóan indokolta tanulmánya relevanciáját: az írását megelőző évtizedekben ugyan több empirikus cikk született a migráció témájában, a demográfusokban azonban szerinte nem volt meg az igény, hogy eredményeiket általános elméletté formálják.
} 
közgazdaságtan és a viselkedés-gazdaságtan bizonyos vívmányaival. Álláspontunk szerint így realisztikusabb kép adható az egyén migrációs döntését alakító tényezőkről. Az intézményi- és viselkedési közgazdaságtani megközelítés ugyanis a neoklasszikus közgazdaság-tudományi irodalomhoz képest nem csak árnyalja a modell szereplőjét, hanem légüres tér helyett társadalmi kontextusba is ágyazza azt. Egy olyan közegbe, ahol a külső környezet mellett a társas kapcsolatok is számítanak és értékkel bírnak - ráadásul az intézményi szemléletmód mindezt a formális modellalkotással kombinálva teszi lehetővé. Ez persze nem jelenti azt, hogy modellünket a „kizárólagos” vagy az „univerzális” jelzőkkel kívánnánk illetni. Az elméletalkotás és modellezés velejárójaként természetesen maradnak olyan tényezők, amelyek magyarázata kívül esik elméletünk „hatókörén”. Modellünk ugyanakkor a tekintetben „inkluzívnak” mondható, hogy egységes közgazdasági elméleti keretbe foglal és szintetizál több olyan, a neoklasszikus közgazdaságtanon kívül eső ismeretet, amely korábban szeparáltan meglévő iskolák, illetve tudományterületek irodalmában volt fellelhető. Disszertációnk elméleti hozzájárulása így egy intézményi közgazdaságtani megalapozottságú migrációs modell lesz. Ez természetesen nem jelenti azt, hogy fókuszunkban kizárólag maguk az intézmények állnának - intézményi közgazdaságtani megközelítés alatt azt értjük, hogy azon fogalmakat, vívmányokat használjuk (korlátozott racionalitás, tranzakciós költségek, specifikus beruházások stb.), amelyek ezen irányzat eszköztárába tartoznak.

Mint azt már hangsúlyoztuk, a migráció sokrétü jelenség, célját és jellegét tekintve is különböző formákat ölthet, s ezen eltérő típusok különböző kérdéseket és elemzési problémákat vetnek fel a kutatók számára (Kiss, 2019; Szentes, 2019). Jelen disszertációban a migrációt az elvándorlás irányából közelítjük meg (szemben a bevándorlási oldallal), s annak okaira, mozgatórugóira fókuszálunk. Érdeklődésünk középpontjában az egyéni hajlandóságot, illetve döntést befolyásoló tényezők állnak, így a makroszintü áramlások mértékének, irányainak és mintázatainak vizsgálata kívül esik jelen disszertáció keretein. Történeti megközelítésre, elemzésre ugyancsak nem vállalkozunk. Migráció, elvándorlás vagy kivándorlás alatt jellemzően tartós letelepedési és/vagy munkavégzési célú, önkéntes, országhatáron átnyúló lakhelyváltoztatást értünk. E meghatározás alá a születési hely szerinti ország elhagyása mellett a visszatérő, vagy bizonyos ismételt migrációs aktusok is besorolhatók, s állításaink ezekre is érvényesek, jóllehet, specifikus jellegüket külön nem tárgyaljuk. ${ }^{2}$ A kényszerü migráció, a

\footnotetext{
${ }^{2}$ Bár bizonyos hatások egy szükebben definiált migrációtípuson élesebben kirajzolódhatnának, célunk itt egy általános modell építése.
} 
menedékesség, a tanulási célú mobilitás, az ingázó munkavállalás vagy rövid távú, illetve időszakos cirkuláris mobilitás ugyanakkor kívül esnek disszertációnk fókuszán.

Mindezek tükrében jelen disszertációban arra a kérdésre keressük a választ, hogy a migráció neoklasszikus közgazdaságtani megközelitésében számontartott faktorokon túl milyen intézményi közgazdaságtani tényezők és viselkedési motívumok befolyásolják az egyén kivándorlási hajlandóságát. Kutatási kérdésünkre a következő hipotéziseket adjuk:

- H1: Az országok intézményrendszereinek minősége befolyásolja az egyén kivándorlási hajlandóságát. A származási ország jó intézményrendszere marasztaló, míg a rossz intézményrendszer taszitó hatással bír a potenciális migránsokra.

Ma már szinte közhelynek számít a közgazdaság-tudomány főáramán belül is, hogy az intézmények számítanak. Noha ennek begyürüzésének jelei már látszanak a migrációs irodalomban, az egyén szempontjából értelmezett, átfogó, intézményi közgazdaságtani elmélet felvázolására mindezidáig még nem került sor.

- H2: A tranzakciós költségek mértéke, amellyel az egyén a keresés, illetve a migráció megvalósitása során szembesül, befolyásolja a kivándorlási hajlandóságát. A tranzakciós költségek mértéke és a kivándorlási hajlandóság között negatív irányú kapcsolatot áll fent.

Noha a neoklasszikus közgazdaságtani modellek rendre a tökéletes racionalitás talaján állnak, a racionalitási posztulátum empirikus igazolhatatlanságához nem fér kétség, ami a migrációs modellekben is indokolja a korlátozott racionalitás koncepciójának használatát. Ennek egyik legfontosabb következménye a tranzakciós költségek „megjelenése”. Bár a korábbi irodalmak rendre tárgyaltak a migráció befolyásoló tényezői között bizonyos tranzakciós költség-jellegü tényezőket, jelen disszertációban ennek egy egységes, az intézményi közgazdaságtan vívmányait használó elméleti keretet kívánunk adni.

- H3: A specifikus beruházások léte és mértéke befolyásolja az egyén kivándorlási hajlandóságát. A specifikus beruházások mértéke és a kivándorlási hajlandóság között negatív irányú kapcsolat áll fent.

A relációspecifikus beruházások mértéke döntő befolyással bír egy kapcsolat tartósságára nézve. A specifikus beruházások megléte szélsőségesen fogalmazva képes lehet „egymáshoz láncolni” az üzleti partnereket. 
Álláspontunk szerint hasonló jelenség a migrációt fontolgató egyén és a származási országa között is fennállhat.

- H4: Az egyén altruizmusából fakadó lelki költségek léte és mértéke befolyásolja a kivándorlási hajlandóságát. Az altruista kapcsolatok, illetve az ebböl fakadó lelki költségek mértéke és a kivándorlási hajlandóság között negatív irányú kapcsolat áll fent.

A racionalitási posztulátumon túl a neoklasszika másik alapvető viselkedési feltevését, az önérdekkövetést is sok kritika érte az elmúlt évtizedekben. Empirikus oldalról az altruizmus létéhez aligha férhet kérdés. Noha azt, hogy az emberek családjukhoz vagy éppen országukhoz való kötődés miatt hajlamosak elvetni a migráció lehetőségét, a társadalomtudományok különböző ágai már több nézőpontból felvázolták, álláspontunk szerint az altruista magatartásforma használata bizonyulhat alkalmasnak arra, hogy ezt egy közgazdasági modellbe is beépítsük.

Kutatásunkban deduktív logikát követünk: dolgozatunk elmélet-orientált, az itt megfogalmazott hipotéziseinknek disszertációnkban elméleti megalapozást adunk, majd empirikus vizsgálataink során teszteljük őket. Ennek első lépése az elméleti modell felépítése, amelyhez az intézményi és a viselkedési közgazdaságtan alapvető vívmányait használjuk fel. Így modellünk többek között a Simon-féle (1987) korlátozott racionalitás koncepcióján, s a North-féle (2010) intézményi elméleten nyugszik. Emellett nagyban építünk a pozitív tranzakciós költségek gondolatára is, amelyet Coase (1937) emelt be a közgazdasági gondolkodásba. Használjuk továbbá a specifikusság fogalmát, amely a Williamson (1985) nevével fémjelzett új intézményi közgazdaságtani irányzat központi eleme. Mindezt az altruizmusnak a Becker-féle (1976) értelmezésével egészítjük ki, amelyet összekötünk Hirschman (1995) hüség-koncepciójával. Mint látható, a H1, H2 és H3 hipotéziseinkben az intézményi közgazdaságtan legfontosabb fogalmait hoztuk összefüggésbe a migrációval. Ezek modellbeli megjelenése ráadásul mind a racionalitás korlátainak elismerésére vezethető vissza. Az altruizmus beemelése $(H 4)$ ugyancsak az elmélet emberképének módosítását jelenti. Így összességében azt mondhatjuk, hogy modellünk implikációinak a neoklasszikusoktól való eltérése alapvetően a viselkedési előfeltevések megváltoztatásával hozható összefüggésbe.

Elméleti modellünk ,jóságát” empirikus vizsgálatok során teszteljük. Az empirikus eredmények alapján azonban nem célunk becslést adni a mintában szereplő országok migrációs potenciáljára vagy várható kivándorlási trendjeire. Elméleti 
modellünk így analitikus - tehát nem történeti megközelítésü - modellnek, empirikus tesztelése pedig egy alkalmazásnak tekinthető.

Az empirikus tesztelést két vizsgálati körben, ökonometriai eszközökkel végezzük az Eurobarometer 2008-as „Eurobarometer 70.1 (Oct-Nov 2008)” és 2010-es „Eurobarometer 73.3 (Mar-Apr 2010)” felmérési adatainak felhasználásával. Vizsgálatunk arra irányul, hogy mely változók esetében figyelhető meg olyan szignifikáns hatás, amely növeli vagy csökkenti az egyén kivándorlási hajlandóságát. Mivel modellünk eredményváltozója, azaz a kivándorlási hajlandóság bináris változó, ezért a standard OLS technika helyett logisztikus regressziókat (logit modelleket) használunk a becsléshez. Az empirikus modelleket a robusztusság ellenőrzése érdekében többfajta specifikációban és (al)mintán becsüljük. Ezek illeszkedését és a különböző modelldiagnosztikai szempontokat a vonatkozó statisztikai mutatók, tesztek és vizsgálatok segítségével ellenőrizzük.

Noha hipotéziseink és felhasznált adataink egyaránt a migrációs hajlandóságra vonatkoznak, ezt megfelelö összefüggésben kezeljük a tényleges migrációval. Az, hogy valaki elképzelhetőnek tartja a külföldre vándorlást a közeljövőben, természetesen nem egyenlő a tényleges elvándorlással. Mint azonban azt részletesen tárgyaljuk, közöttük szoros összefüggés van, s erre építve a szakirodalom is bevett gyakorlatként tekint a hajlandósági adatok felhasználására a migráció szelekciós tényezőinek vizsgálatakor (Zaiceva \& Zimmermann, 2008a). A migrációs hajlandóság vagy szándék, amelyet a hazai szakirodalom többnyire migrációs potenciálként azonosít ${ }^{3}$ (Sik \& Szeitl, 2016a), megjelenése minden esetben megelőzi a kivándorlást, így mozgatórugói is hasonlóak. Jóllehet, ezek egy tökéletesen racionális egyénnél meg is egyeznének, a gyakorlatban nem így van. Az ember hajlamos alábecsülni a kivándorlás költségeit, felülbecsülni a hasznait, így bizonyos tényezők csak a tényleges döntés meghozatalkor mutatkoznak vagy mutatkoznának meg, ráadásul általában a jövőbeli valószínüségeket is tévesen ítéli meg. Így a tényleges migránsok száma minden esetben alacsonyabb, mint a migrációs hajlandóságot megfogalmazóké. Ennek megfelelően a migrációs potenciál mutatók is csak erős felső becslést adnak a várható kivándorlásra. Mindazonáltal szoros kapcsolatuk miatt a két dolog nem választható el egymástól, így jelen disszertációban is egymással összefüggésben - a közöttük lévő különbségek szem előtt tartásával - kezeljük őket.

\footnotetext{
3 A migrációs hajlandóság, szándék és potenciál kifejezéseket általában szinonimaként használjuk a disszertációban, a közöttük meghúzódó esetleges különbséget a 3.1. alfejezetben tárgyaljuk külön.
} 
Munkánk mindezek tükrében több ponton is hozzá kíván járulni mind a migrációs, mind a közgazdaság-tudományi irodalomhoz. Ennek első momentuma az irodalmi áttekintésünkhöz kapcsolódik. Míg a migrációkutatásban gyakorta jellemző, hogy a tanulmányok irodalmi összefoglalója egyszerüen Massey és mtsai (1993) áttekintésére épül, addig jelen disszertációban ezt az említett mü erényeit és vívmányait felhasználva, de azt meghaladva, saját megfontolásaink alapján attól némiképp eltérően, aktualizálva tesszük meg. Ezt egészítjük ki az empirikus munkák áttekintésével, amely széles irodalmi bázisa és rendszerezettsége nyomán ugyancsak fontos adalékként szolgálhat a migrációkutatás számára. Elméleti modellünk újszerüsége két szempontból azonosítható be. Egyrészt a közgazdasági megalapozottságú migrációs modellekben eddig nem használt tényezőket (intézmények, intézményi bizalom) vezetünk be az elméletbe, másrészt más megközelítésekben már tárgyalt szempontoknak adunk új értelmezést az új intézményi és a viselkedési közgazdaságtan fogalomtárának használatával (specifikus beruházások, tranzakciós költségek, altruizmus). Így egy olyan egységes közgazdaságtani keretbe helyezzük a migrációs döntést, amely képes a korábbi tudásanyag szintetizálására, illetve ki is bővíti azt. Mindez közgazdaság-tudományi oldalról is jelentőséggel bír. Új alkalmazási területet adunk az intézményi és a viselkedési közgazdaságtan számára, megmutatva, hogy azok vívmányai a migrációkutatás területén is sikerrel alkalmazhatók. Ennek során Győrffy (2012) intézményi bizalom-modelljének kiterjesztésére is vállalkozást teszünk. Empirikus vizsgálatunk során a területen szokásos módszertant alkalmazzuk, ugyanakkor adataink bemutatása során újszerü struktúrában prezentáljuk a migrációs adatokkal kapcsolatos dilemmákat és nehézségeket.

A disszertáció a továbbiakban hét fő szerkezeti egységre osztható. Jelen bevezetést követően a 1 . fejezetben áttekintjük témánk szakirodalmi hátterét. Ezt két lépésben tesszük meg: először a modellünk megalapozásához szükséges elméleti irodalmakat, majd az azok igazolását szolgáló empirikus irodalmakat dolgozzuk fel. A korábbi eredmények bemutatása mellett rámutatunk az irodalomban meglévő azon hiányosságokra, amelyek pótlására jelen disszertáció vállalkozik. Ezt követően a 2 . fejezetben elméleti modellünket vázoljuk, amelyben a neoklasszikus mikroszemléletü modell alapjaira a viselkedési és az intézményi közgazdaságtan vívmányainak felhasználásával építünk modellt. A 3. fejezetben elöször azt tárgyaljuk, hogy milyen kihívások merültek fel a modell empirikus teszteléséhez szükséges adatok kiválasztásakor, majd ezek tükrében kerül sor a felhasználásra kerülő adatok bemutatására. A 4. fejezetben empirikus vizsgálatunk módszertanát, valamint 
modelljeinek változóit vázoljuk fel. Az 5. fejezetben elemzésünk eredményeit diszkutáljuk, s rámutatunk a mögöttük meghúzódó oksági összefüggésekre. A 6. fejezet a kitekintések mellett a vizsgálat korlátait tartalmazza, végül a Konklúzióban a hipotézisvizsgálattal, a kutatás eredményeinek, valamint a tudományos hozzájárulások összegzésével zárjuk disszertációnkat. 


\section{IRODALMI ÁTTEKINTÉS}

A migráció és a migrációs hajlandóság - mint arra a bevezetésben már utaltunk szorosan összefügg, elméleti irodalma azonban előbbinek bővebb, utóbbi témájában pedig inkább az empirikus tanulmányok a jellemzők. Jelen fejezetben ezen irodalmakat összekapcsolva tekintjük át, fókuszálva a jelenségek okaira, mozgatórugóira, amelyek természetüknél fogva hasonlóak a migrációs szándék és a tényleges elvándorlás esetén is. A két téma irodalmát összefoglalóan migrációs irodalomnak nevezzük.

A migrációs irodalom okokat vizsgáló ága rendkívül sokszínü, még akkor is, ha föként a közgazdasági vonatkozású elméletekre fókuszálunk (további megközelítésekről lásd például Carling \& Collins, 2018). E téren alapvető referenciának számítanak Massey és mtsai. (1993; 1998) összegző munkái, de más alapos áttekintések is születtek az elmúlt évtizedekben (Bauer \& Zimmermann, 1995; Hagen-Zanker, 2008; Molho, 2013; Stahl, 1995). Ezekre részben támaszkodni fogunk, azonban disszertációnk gondolatvezetésének megfelelően új kategorizálást alkotunk a szakirodalom bemutatásakor. A továbbiakban két részre, egy elméleti és egy empirikus blokkra, bontva mutatjuk be az irodalmat. Erre azért van szükség, mert utóbbiak esetén a rendelkezésre álló adatok természetéből fakadóan nem az elméleti irodalmakkal egyező struktúrában különíthetők el a mikro-, illetve makroszintủ elemzések (gyakran a mikroszintủ elméletek implikációt is aggregált adatokon tesztelik). Ugyancsak hangsúlyozandó, hogy az áttekintéssel saját elméletünket kívánjuk elhelyezni a szakirodalomban, s viszonyítani azt a korábbi munkákhoz. Így kizárólag azon irodalmak ismertetésére szorítkozunk, amelyek valamilyen szempontból kapcsolódnak jelen kutatáshoz, s amelyek eredményeire építeni is fogunk.

Mindezek alapján irodalmi áttekintésünket a vonatkozó migrációs elméletek bemutatásával kezdjük. Noha disszertációnk elemzési egysége az egyén, s így mikroszintű megközelítést alkalmazunk, kitérünk a migráció neoklasszikus közgazdaságtani makroszemléletű megközelítésére, mivel annak megállapításai már előrevetítik az áramlások potenciális irányait, s csak ezek ismeretében célszerű a migránsok egyéni szelekciójáról beszélni. Ezt követően bemutatjuk a vonzás-taszítás elméletét, amely értelmezésünk szerint a mikro- és makroszintü megközelítések között helyezkedik el, hiszen mindkét szintről használ tényezőket a mozgások magyarázatára. Ezután részletesebben rátérünk a mikroökonómiai (humántőke) irányzatra, amely jelen disszertáció kiindulópontját is adja. Ezen irányzatnak a különböző továbbfejlesztett 
modelljeiről, valamint további behaviorista megközelítésekről is értekezünk. A migráció új közgazdaságtanának nevezett iskoláról saját szemléletmódunk beszélünk, rámutatva a köztük lévő hasonlóságokra és a különbségekre. Végül röviden ismertetünk néhány további, jelen kutatáshoz kapcsolódó - elsősorban szociológiai gyökerü - elméleti megközelítést.

Ezt az empirikus irodalmak bemutatása követi, amelyben - összhangban Bauer \& Zimmermann (1995) felosztásával - két irányzatot azonosítottunk: a főként makroszintű adatokat használó, az áramlásokat aggregált szinten vizsgáló ágat, valamint a (potenciális) migránsok szelekcióját, s a kivándorlást valószínűsítő tényezőket egyéni szintü adatokkal elemző ágat. ${ }^{4}$

\subsection{Migrációs elméletek}

\subsubsection{Makroökonómiai irányzat}

A nemzetközi migráció legalapvetőbb, neoklasszikus makrogazdasági elmélete egyensúlyi mechanizmusként tekint a vándorlásra (Hagen-Zanker, 2008). Eszerint a migráció mértékét és irányát - a belső migrációhoz hasonlóan ${ }^{5}$ (Harris \& Todaro, 1970) - a termelési tényezők, így a tőke és a munka keresleti, illetve kínálati viszonyai határozzák meg: a migránsok a tőkével gazdagon, ám munkaerővel relatíve kevésbé ellátott, s ezáltal magasabb bérszínvonalú területekre áramlanak. Hicks (1963) ennek megfelelően utóbbit, a bérkülönbségeket tekinti a migráció fó okának. Amint azt Lewis (1954) kiemeli, a folyamatot az indítja be, hogy a kapitalista gazdaságok tőkefelhalmozása gyorsabb a népesség növekedésénél, ami a bérek emelkedéséhez vezet, ez pedig bevonzza a külföldi munkaerőt. A tömeges migráció, valamint az ezzel párhuzamosan beinduló tőkeexport azonban idővel megteremti az egyensúlyt a termelési tényezők nemzetközi piacán. ${ }^{6}$ Ugyanez a másik oldalról megközelítve: a nagy népességnövekedés a munkanélküliség növekedéséhez vezet a fejlődő országokban, ami - a fejlődő és fejlett országok közötti jövedelmi olló szétnyílásával - migrációra ösztönözi

\footnotetext{
${ }^{4}$ Jelen fejezet szerkesztett változata megjelent: Golovics (2019a).

${ }^{5}$ A migrációs elméletek egy jelentős része nem tesz éles különbséget a nemzetközi és az államhatárokon belüli migráció magyarázatában, mivel az egyszerübb - föként az intézményi környezetet ignoráló absztrakt közgazdasági modellekben ez nem befolyásolja azok következtetéseit. Bauer \& Zimmermann (1995) megfogalmazásában a belső és a nemzetközi migráció lényegében csak az intézményi környezetükben különböznek egymástól, s mint azt Eriksson (1989) empirikusan is alátámasztotta, a két jelenség mozgatórugói nem különböznek érdemben akkor, ha a nemzetközi migráció jogi akadályait minimalizálják.

${ }^{6}$ Borjas (1989) nyomán megemlítendő, hogy a Heckser-Olin-Samuelson modell migráció nélkül is a termelési tényezők árának kiegyenlítődését prediktálja, így a munkaerő nemzetközi áramlásának e keretbe történő beemelése nem okoz érdemi változást a modell implikációiban.
} 
az előbbiekben élő munkaerőt. Célpontjaik pedig a magas jövedelmi szintü, alacsony munkanélküliségi rátával rendelkező államok lesznek.

Ez az irányzat tehát az egyes országok termelési tényezőkkel való ellátottságát tekinti a migráció fő mozgatórugóinak, s ezzel összefüggésben a jelenség vizsgálatakor a bérszínvonalra és a munkanélküliség elemzésére helyezi a hangsúlyt. Kiemelendő ugyanakkor, hogy ezen elméletek a múlt században, főként a fejlődő és a fejlett országok között végbemenő migrációs folyamatok magyarázatára születtek. Ebben a relációban pedig a modellek magyarázó változói rendre korrelálnak az országok általános fejlettségével, ami még tovább egyszerüsíti a leírtakat, azt sugallva, hogy a migránsok egyszerüen a fejletlenebb területekről a fejlettebbek felé vándorolnak. ${ }^{7}$ Ugyanakkor empirikus bizonyítékok az egyensúly megvalósulására - ideértve a bérek kiegyenlítődését - nem tapasztalhatók. Emellett a makroökonómiai elmélet egyáltalán nem foglalkozik a szelekció kérdésével: nem ad magyarázatot arra, hogy azonos makrogazdasági körülmények között bizonyos egyének miért döntenek a migráció mellett, amíg mások a helyben maradást választják.

\subsubsection{Vonzás-taszítás elmélete}

Az általános gazdasági helyzetet, valamint munkaerőpiaci viszonyokat leíró tényezők - így többek között a bérszínvonal - szerepét a több elemzési szinttel együttesen foglalkozó vonzás-taszítás (push-pull) elmélete is megerősíti. A teória előfutárának Ravenstein $(1885 ; 1889)$ tekinthető, aki a 19. század végén fogalmazta meg a „migráció törvényeit”, mely alatt saját szóhasználatával az általa megfigyelt empirikus „törvényszerüségeket” értette. Az elméletet a 20. században Lee (1966) elevenítette fel és formálta újjá, matematikai formalizálását Dorigo \& Tobler (1983) végezte el, Zimmermann (1994) a komparatív statika módszerével vizsgálta a munkaerőpiaci tényezők migrációra gyakorolt vonzó, illetve taszító hatását, Tobler (1995) pedig 20. századi adatokon tesztelte - vegyes eredményekkel - Ravenstein törvényeinek időtállóságát. Legfrissebb vívmányként Van Hear, Bakewell, \& Long (2018) „push-pull plus” elmélete említhető, amely cizellálja a különböző húzó és taszító tényezőket, kiemeli a közöttük lévő különbségeket, illetve csoportosítja őket.

\footnotetext{
${ }^{7}$ Az egyszerübb makromodellek természetesen kiegészíthetők további tényezőkkel. Tekintve azonban, hogy ezek tárgyalása kívül esik jelen disszertáció fókuszán, bemutatásuktól eltekintünk. A külkereskedelem és a migráció közötti összefüggésekről például jó áttekintést ad Fassmann \& Münz (1997), illetve Kutasi (2005), a további szempontokhoz pedig Bauer \& Zimmermann (1995) nyújt iránymutatást.
} 
Noha a vonzás és taszítás elmélete is elsősorban az áramlások irányának és mértékének magyarázatára fókuszál, már megjelenik benne a migrációs döntést meghozó egyén. Noha döntését többségében olyan külső makroszintű tényezők befolyásolják, amelyek jelenlegi lakhelyére, illetve a potenciális célterületre jellemzők, a személyes vonatkozású motívumok sem hanyagolhatók el. A származási országban meglévő negatív tényezők, úgynevezett taszító faktorok növelhetik az elvándorlás valószínüségét, míg a célországba pozitív, húzó faktorok csábíthatják a migrációt fontolgató egyéneket. Ezen tényezők területenként eltérő mintázatot mutatnak, s noha többségüket az emberek hasonlóan értékelik, a potenciális migránsok heterogenitása miatt bizonyos faktorok egyénenként különbözően hathatnak. Emellett az elmélet számol az elvándorlás kapcsán felmerülő akadályokkal, így a tényleges áramlások mindezek eredőjeként értelmezhetők az iskola szerint. A célterület húzó faktorai között olyan tényezök említhetők, mint a magasabb élet-, illetve bérszínvonal, az alacsonyabb munkanélküliség vagy a kormányzat kedvező közpolitikai programjai (utóbbiakat például az egyéni élethelyzet függvényében már különbözően értékelhetik az emberek), míg a taszító faktorok között ezek ellentétei vagy akár a politikai instabilitással, a demokrácia hiányával, illetve az éghajlattal kapcsolatos szempontok említhetök. Ezen makro-faktorok mellett azonban olyan egyéni tényezőkre vonatkozó megállapítások is megjelennek Ravenstein (1885) törvényei között, amelyekkel később a mikroszintü elméletek, valamint jelen disszertáció is foglalkozik. Ilyen például, hogy a vidékiek nagyvárosok lakóinál hajlamosabbak lehetnek az elvándorlásra, illetve a nők dominanciája a migránsok körében ${ }^{8}$. Disszertációnk szempontjából ugyancsak megjegyzendő momentum, hogy Dorigo \& Tobler (1983) a barátoktól és az ismerős környezettől való elszakadást a taszító faktorok erejét csökkentő tényezőként említik, azonban ennek részletes tárgyalására nem térnek ki.

Mindezek tükrében a vonzás-taszítás elmélete a makroökonómiai megközelítéshez képest árnyaltabb képet fest a migrációs folyamatokról. Továbbá magyarázatot ad arra is, hogy a globális szinten prediktált potenciális egyensúly - a faktorok egyénekre gyakorolt eltérő hatása és a munkaerő heterogenitása miatt - miért nem kell, hogy szükségszerüen a bérek teljes kiegyenlítődéséhez vezessen (Zimmermann, 1994).

E megközelítésmód így több mint egy évszázados viszonylatban ad keretet a migrációs folyamatok elemzéséhez, s az is kétségtelen, hogy az általános makrogazdasági

\footnotetext{
${ }^{8}$ Fontos megjegyezni, hogy ezek a kijelentés Ravensteinnél (1885) a 19. század végi belső migrációra vonatkoztak, így napjaink áramlásaira már nem feltétlenül igazak.
} 
tényezők alapjaiban határozzák meg ezek irányát. Mindazonáltal Portes \& Böröcz (1989) helyesen hívják fel a figyelmet arra, hogy noha az elmélet post factum valóban magyarázatot ad egyes mozgásokra, azzal kapcsolatban nincs mondanivalója, hogy más hasonló helyzetekben és viszonylatokban miért nem indul meg migráció. Ezt azzal állítják összefüggésbe, hogy a vonzás-taszítás kontextusában íródott munkákban a mikro és a makro elemzési szintek nem különülnek el megfelelő módon. Ezen felül pedig - mint azt empirikus példákkal is alátámasztják - arra sem képesek magyarázatot adni, hogy az egyes faktorok hatásának (például a bérkülönbségek) csökkenésekor az áramlások miért nem mérséklődnek az elmélet által prognosztizált módon.

További kritikaként fogalmazható meg, hogy a vonzás-taszítás hagyományos elmélete - illetve annak az alább bemutatandó mikroökonómiai megközelítés által még nem befolyásolt része - a kivándorlási döntés természetével csak absztrakt szinten foglalkozik. Noha Lee (1966) felsorolja, s egy folyamatábrán bemutatja a döntést befolyásoló tényezőket, illetve jelzi, hogy az sosem teljesen racionális (sőt egyeseknél az irracionális elemek többségben is vannak), annak szisztematikus közgazdasági jellegü leírására nem kerül sor. A matematikai formalizálás pedig Dorigo \& Tobler (1983) munkájában is csak a makroszintü áramlásokra vonatkozik. Mindezek plasztikusan összegezhetők Hagen-Zanker (2008) kritikájával, amely szerint a push-pull megközelítés valójában csak csoportosítja a migrációt befolyásoló tényezőket, ám az oksági viszonyok pontos leírásának hiányában aligha tekinthető valódi elméletnek. Mindez abban is megmutatkozik, hogy a taszítás és vonzás fogalmai a migrációs irodalom más iskoláiban, teljesen más kontextusban, mögöttes elméleti megalapozás nélkül is (lásd például Haug (2008) munkáját a később tárgyalandó migrációs hálózatokról) gyakorta megjelennek.

\subsubsection{Mikroökonómiai humántőke elmélet}

Mindezen hiányosságok szükségessé teszik, hogy - a módszertani individualizmus elvének megfelelően - a migráció mozgatórugóinak megértésekor az egyéni szintig nyúljunk le, az egyént tegyük meg elemzési egységül és az ő döntéséből, illetve döntését befolyásoló tényezőiből vezessük le a nemzetközi vándorlási folyamatokat. Ez a megközelítésmód egyben azt is lehetővé teszi, hogy az áramlások irányán és mértékén túl a migránsok szelekcióját is értelmezni tudjuk. A migrációelmélet mikroökonómiai irányzatához a Becker (1962), Mincer (1958), valamint Schultz (1983) neveihez köthető humántőke-elmélet adja a kiindulópontot. Ennek lényege, hogy az egyén a tudásával, emberi tőkéjével a többi termelési tényezőhöz hasonlóan próbál racionálisan gazdálkodni, így például az oktatás révén beruházást eszközöl abba, 
amelynek a munkaerő-piacon a legjobb megtérülését keresi majd - legyen szó hazai vagy éppen külföldi „hasznosításról”.

Ennek megfelelően a migráció mikroökonómiai elmélete - amelyről áttekintést ad DaVanzo (1981a) - egy beruházásként tekint az elvándorlásra, amelynek a jövőbeni megtérülés, azaz a jobb élet reményében költségei is vannak. Ezen gondolkodási keret alapjait Sjaastad (1962) fektettte le, munkaerőpiaci kontextusba helyezett tovább gondolását Bodenhöfer (1967) és Todaro (1969), további formalizálásait pedig többek között Hart (1975), illetve Todaro \& Maruszko (1987) végezték el. E megközelítés immáron nem az aggregált áramlásokra koncentrál, hanem egy individuális, önérdekvezérelt, haszonmaximalizáló döntésként kezeli a migrációt, amelyet az egyén racionálisan, a vonatkozó költségek és hasznok mérlegelésével hoz meg. E költséghaszon kalkuláció értelmében akkor választja a kivándorlást, ha az nettó hasznosságnövekedéssel jár számára.

A hasznok között Sjaastad (1962) pénzbeli és nem pénzbeli tényezőket egyaránt említ. Előbbiek eredőjét a munkajövedelemben, valamint a munkavállalás költségeiben és a fogyasztási javak árában elérhető megtakarítások kombinációja adhatja, utóbbiak közé pedig az új lakhely iránti preferenciából (például kedvezőbb klíma miatt), illetve a jobb fogyasztási lehetőségekből fakadó hasznosságnövekmények sorolhatók. Mindezen túl az irodalom a hasznok között említi még az esetleges béren kívüli többletjuttatásokat is. Továbbá - összhangban a Tiebout (1956) hipotézisében megfogalmazott adóközjószág csomagok iránti preferenciák elméletével - a kormányzat által nyújtott költségvetési támogatások és egyéb közszolgáltatások, valamint a közpénzügyi rendszer által az egyénre rótt terhek (például adók) egymáshoz viszonyított aránya is idesorolható (DaVanzo, 1981a). Utóbbiak összességét jelen disszertációban a nettó közszolgáltatási szint kifejezéssel illetjük. E hasznok - vagy legalábbis egy részük - nem csak a migrációs döntés meghozatalát követően, hanem az életpálya hátralevő részén is jelentkeznek, így a vonatkozó modellek gyakran az összes jövőbeli haszon diszkontált jelenértékével számolnak. Mivel a hasznok az egyén eredeti lakhelyén és a vándorlás célállomásán is jelen vannak valamilyen mértékben, így ezeket - illetve várható értéküket - a potenciális migráns preferenciái szerint összegezi, s területenként összehasonlítja őket.

A hasznok mellett a döntést a kivándorlás költségei befolyásolják még, amelyeket mobilitási költségeknek is szokás nevezni. Ezeket Sjaastad (1962) ugyancsak a 
pénzbeliség ismérve mentén csoportosítja. ${ }^{9}$ A pénzbeliek közé a vándorlás közvetlen költségeit, a nem pénzbeliekhez pedig az utazás vagy az új állás keresése miatt elszalasztott jövedelmet (lehetőség költséget), valamint a távozás, így a család vagy az ismerős környezet elhagyása nyomán jelentkező lelki költségeket sorolja. Ezt kiegészítve az irodalom további vívmányaival, a mobilitási költségek között olyan egyéb tényezőket tarthatunk számon, mint a külföldi megélhetés esetleges többletköltségeit, a hozzátartozókkal való kapcsolattartás költségeit vagy az új nyelv elsajátításának, valamint az új környezethez és kultúrához való alkalmazkodás terheit (Bauer \& Zimmermann, 1995; DaVanzo, 1981a; Massey és mtsai., 1993).

Fontos kiemelni, hogy a hivatkozott irodalmak rendre hangsúlyozzák a nem pénzbeli, a korábbi kapcsolatok feladásával járó lelki költségek szerepét, azonban természetük részletes tárgyalására, s müködési mechanizmusuk közgazdaságtani terminológiával történő leírására nem térnek ki. Sjaastad (1962) ezt azzal indokolja, hogy a lelki költségek mértéke nem kvantifikálható, ráadásul, ha az is lenne, akkor sem lehetne valódi költségként kezelni. Bodenhöfer (1967) ugyancsak így érvel. A lelki költségek ugyanis szerintük az elmaradó fogyasztói többlethez hasonlítanak, valós kiadást nem eredményeznek, s ezáltal érdemben nem befolyásolják a potenciális elvándorlók döntését. Jelen disszertációban azonban szembehelyezkedünk ezen állásponttal. Mivel a hivatkozott irodalmak mindegyike említi a lelki költségek szerepét, s az intuíció is azt sugallja, hogy érdemes foglalkozni velük, ezért a lelki költségeket a közgazdasági terminológiában is értelmezhető módon, valódi költségként illesztjük be modellünkbe, $\mathrm{s}$ jelentőségüket empirikus tesztnek is alávetjük.

A lelki költségek jelentősebb figyelmet csak Morgan \& Deaton (1975), illetve Deaton, Morgan, \& Anschel (1982) munkáiban kaptak, bár ők sem valódi erőforrás költségként kezelték őket. Utóbbiak a földrajzi régiók iránti hasznosságkülönbségek szignáljaként, tehát nem a családtagok hátra hagyásával járó veszteségként kezelték őket (empirikus felmérésük kérdései ugyanis a családdal közösen történő költözésre vonatkoztak). Azt azonban - jelen disszertációhoz hasonlóan - mindkét tanulmány

\footnotetext{
9 Megjegyzendő, hogy a fenti kategorizálás mellett Sjaastad (1962) beszél egyéni és társadalmi költségekről, valamint hasznokról is. Ezen kategorizálást azonban jelen disszertációban nem használjuk. Ennek elsődleges oka, hogy a közgazdaság-tudomány neoklasszikus premisszái alapján az önérdekkövető egyén döntésében csak a saját maga számára jelentkező költségeket és hasznokat veszi számításba. Azzal persze egyetértünk, hogy az elvándorlási döntésnek van másokra gyakorolt hatása, ezt pedig bizonyos esetekben a potenciális migráns is figyelembe veheti. Ezt az ellentmondást azonban nem a Sjaastad-féle felosztással, hanem az interdependens hasznossági függvények alkalmazásával kívánjuk feloldani, amelynek bemutatására a 2.3.5. alfejezetben kerül sor.
} 
szerzői hangsúlyozták, hogy ezen lelki költségeknek fontos ellensúly-szerepe lehet a hatalmas bérkülönbségekkel szemben. Mindazonáltal formális modellt nem építettek a gondolatra, elemzéseik inkább a lelki költségek nagyságát alakító tényezőkre fókuszáltak, empirikus vizsgálataikat pedig amerikai viszonylatban, belső migrációra vonatkozóan végezték el. Állításaik így jobbára a vidék-városi vándorlási folyamatokra, s az ezen helyek adta sajátosságok iránti preferenciákra vonatkoztathatók.

A fenti alapmodellben implicite az is benne foglaltatik, hogy az intézmények fontosak a migrációs döntés meghozatalában. Ennek megnyilvánulása - mint azt az empirikus irodalmakat taglaló fejezetben részletesen is bemutatjuk -, hogy a bevándorlási és munkaerőpiaci szabályozásból adódó terhek vagy a kulturális, illetve nyelvi különbségek kezeléséből adódó nehézségek számbavételre kerülnek a kivándorlás költségei vagy a maximalizálás korlátai között (lásd például Borjas, 1989). Ezeknek a döntésekre gyakorolt hatását azonban az irodalom rendre csak anyagiasított, az egyéni hasznossági függvénybe beépíthető formában vagy az empirikus elemzés egy egyszerü változójaként tárgyalja. E megközelítésekből hiányzik az intézmények és az aktorok viszonyát, kölcsönhatását leíró egységes elméleti háttér, amely a migrációs döntések természetének mélyebb megértéséhez segítene hozzá. Jelen disszertációban azonban e téren is előre kívánunk lépni: az intézményi közgazdaságtan vívmányainak felhasználásával bemutatjuk, hogy mi az intézmények funkciója az egyéni döntésekben, s levezetjük, hogy az intézményi működés milyen hatást gyakorol az elvándorlási döntésekre.

A neoklasszikus modellek tárgyalásakor kiemelendő az is, hogy a migrációs döntések kapcsán több szerző is használja a helyszín-specifikus tőke fogalmát. DaVanzo (1981a; 1981b) a migráció költségei között említi, Haug (2008) a később tárgyalandó migrációs hálózatokkal, egészen pontosan az egyén lakóhelyén meglévő társadalmi közeggel hozza összefüggésbe, Mulder \& Wagner (2012) pedig szintén a lakhely iránti kötelékekként tekint rájuk. Maga a fogalom, s jelentéstartalma nagymértékben rokonítható azzal a koncepcióval, amelyet jelen disszertációban a Williamson-féle specifikus beruházások fogalmának bevezetésével építünk fel, hiszen DaVanzo is megfogalmazza, hogy specifikusságából fakadóan ezen tőke értéke csökken a kivándorlással, Haug pedig affinitási hipotézisében írja le, hogy a helyben meglévő kapcsolatok egyfajta visszatartó beruházásként csökkentik a kivándorlás valószínűségét. Érdekesség továbbá, hogy az életkor szerepének tárgyalásakor Sjaastad (1962) a humántőke-elmélet alapmodelljében is a specifikus beruházások „müködésére” hajazó 
mechanizmust említ, noha értelemszerüen nem nevezi így a jelenséget. Mint írja, a fiatalabb személyek munkaerő-piacon hasznosítható tudása jobbára a formális oktatásból származó ismeretekből áll, s az adott szakmára jellemző sajátos, tapasztalattal szerzett tudás náluk csak kisebb mértékben jelenik meg. Ez pedig a humántőkéjüket külföldön is jobban hasznosíthatóvá teszi.

Mindazonáltal Haug (2008) a szociológiából gyökereztetve, a Granovetter-féle (1985) beágyazottság és a Coleman-féle (1988) társadalmi tőke elméletére alapozva használja a specifikusság fogalmát, s inkább a célországban meglévő helyszín-specifikus tőke szerepét hangsúlyozza. Mulder \& Wagner (2012) szintén említi a hálózatokat a helyszínspecifikus tőke egyik formájaként, emellett azonban inkább példák segítségével (pl. adott helyen töltött gyermekkor, ingatlantulajdonlás) vezeti be a fogalmat. DaVanzo (1981a; 1981b) ugyan - a szociológiai megközelítésekkel szemben - közgazdasági terminusként hivatkozik rá, de ezt nem a Williamson-féle fogalomrendszerben teszi, Sjaastad (1962) pedig egyáltalán nem használja a kifejezést. Következésképp, egyikük koncepciója és eredményei sem illeszthetők be automatikusan egy intézményi közgazdaságtani modellbe. Jelen disszertációban azonban a DaVanzo gondolatával rokonítható specifikusság fogalmát a Williamson (1985) munkásságára épülő paradigma nyomán dolgozzuk ki, s helyezzük egy egységes elméleti keretbe.

A humántőke-megközelítés magyarázóereje összességében tehát túlmutat a korábban bemutatott elméletekén. Ez ugyanis nem pusztán az áramlások irányát és mértékét magyarázza, hanem foglalkozik a szelekció kérdésével is, azzal, hogy a heterogén embertömegböl kik lesznek azok, akik a migráció mellett döntenek. Hasonlóan a makroelméletekhez, a bérkülönbségek és munkapiaci tényezők itt is döntő fontosságúnak számítanak, de a migráció mikröokoómiai megközelítése nem az átlagokra, az aggregált mennyiségekre helyezi a hangsúlyt. Az egyének számára elérhető bérek vagy munkalehetőségek ugyanis eltőrek: a saját humántőkéjük karakterisztikumaitól függenek. Így ez az elmélet az egyes országok munkaerőpiaci jellemzőinek figyelembevétele mellett választ ad arra a kérdésre is, hogy egy alacsony bérszínvonalú ország dolgozói közül kik lesznek hajlamosak az elvándorlásra: akik a humántőkéjüket könnyebben, nagyobb megtérüléssel és hosszabb időhorizonton tudják hasznosítani a célországban (így például a nyelvtudással rendelkező, magasan képzett fiatalok, akik a migráció adta előnyöket hosszabb időhorizonton élvezhetik). 


\subsubsection{A mikroökonómiai modell továbblépési irányai}

A fentiek tükrében a migráció módszertani individualizmus talaján álló mikroökonómiai elmélete komplex képet ad a vándorlási folyamatok okairól, befolyásoló tényezőiről, azonban több ponton még így is elnagyoltnak tekinthető. Ebből kifolyólag az alapmodellnek több módosított, továbbfejlesztett változata létezik. Ezek egyik szegmense egy adott résztémára fókuszál, a másik pedig - amelyet a későbbiekben mutatunk be részletesen - a kiinduló modell egyszerüsítő feltevéseinek feloldásával, megváltoztatásával kíván javítani az elmélet magyarázó erején, s közelebb hozni azt a valósághoz. Előbbiekre példa Todaro \& Maruszko (1987) illegális migrációval foglalkozó tanulmánya vagy Djajic \& Milbourne (1988) és Dustmann (2003) vendégmunkára, illetve ideiglenes migrációra fókuszáló modelljei, de ide sorolhatók Borjas $(1989,1991,2014)$ szelekciót tárgyaló írásai is.

Borjas (1989) az emberek országok közötti allokációját a szakmák közötti allokáció kérdéséhez hasonlította, s ennek megfelelően Roy (1951) szakmaválasztási modelljét használta fel a migránsok szelekciójának elemzéséhez. Ebben a modellben Borjas (2014) a képzettségek megtérülési rátájának országok közötti eltéréseire helyezi a hangsúlyt. Megfogalmazásában akkor beszélhetünk pozitív szelekcióról, amikor a küldő ország munkaerőpaica a fogadó országéhoz képest relatíve alacsonyabb többlettel díjazza a magasabb képzettségeket (azaz az oktatásban való részvétel megtérülési rátája relatíve kisebb). Erre példa lehet többek között a küldő országban müködő progresszív adórendszer. Ilyen esetben azok döntenek a migráció mellett, akik mind a küldő, mind a fogadó országban átlag feletti képzettséggel, s ennek megfelelően keresettel rendelkezn(én)ek. Ha a képzettségek és a mobilitás költségei között negatív elöjelü korreláció figyelhető meg, az ugyancsak az ilyen, pozitív szelekció valószínüségét növeli. Negatív szelekcióról az előbbiek ellenkezője esetén beszélhetnénk. A harmadik lehetőséget, amikor az elvándorlók a küldő országban átlag alatt, ám a célországban átlag felett keresnének, inverz kiválasztásnak (inverse sorting) nevezi. Ez ugyancsak a képzettségek megtérülési rátájával állhat összefüggésben, s így a származási országban úgynevezett alulértékelt szakmák képviselőit ösztönözheti elvándorlásra. Mindezek tükrében a modell megalapozottan érvel amellett, hogy a nemzetközi migráció megértésében nem az átlagbérekre, hanem a képzettségek megtérülési rátájára érdemes fordítani a figyelmet, s arra is bizonyítékkal szolgál, hogy a különböző körülmények különböző típusú (például képzettségü) emberek számára tehetik racionálissá az elvándorlást. Mindazonáltal a modell erős korlátozó tényezőjének mondható, hogy a 
származási és a célországbeli béreket exogén módon kezeli, holott nagyobb volumen esetén a vándorlásoknak nyilvánvaló hatása van rájuk. ${ }^{10}$

Ahogyan arra korábban utaltunk, a migrációkutatás egy másik szegmense a humántőke-elmélet bizonyos pontjainak felülvizsgálatával kívánta továbbfejleszteni az alapmodell magyarázó-erejét. A legfontosabb ilyen pont a modell emberképe, azaz az aktorra vonatkozó viselkedési elöfeltevések. Ezek közül is kiemelendő a szereplök informáltságának kérdése. Míg a kiinduló modellek rendszerint tökéletes racionalitást, s ezzel összhangban teljes informáltságot feltételeznek az egyénről, addig a későbbi tanulmányok gyakran lazítanak ezen a viselkedési előfeltevésen.

Ezek között elsőként a Katz \& Stark (1987) által felírt és Bauer \& Zimmermann (1995) által is feldolgozott, információs aszimmetriára épülő modell említendő, amely azonban nem a migráns, hanem a fogadó ország munkaadójának hiányos informáltságából fakadó következményeket vizsgálja. Tekintve, hogy ez a modell gyakorlatilag az Akerlof-féle (1970) tragacspiac külföldi munkavállalásra átfordított változata, következtetései is megegyeznek vele: mivel a munkaadók rövid távon nem tudják megfigyelni a migránsok termelékenységét, ezért mindenkinek csak egy átlagos bért hajlandók fizetni, ami azonban kizárólag a képzetlenebbek számára ad ösztönzést a migrációra. Kedvetőtlen helyzetükön a képzettebbek szignálozással tudnának javítani, ami azonban nem csak számukra költséges, de össztársadalmi szempontból is hatékonyságveszteséggel jár.

Kutatásunk szempontjából nagyobb relevanciával bírnak azok a modellek, amelyek a migrációs döntést fontolgató egyén kapcsán lazítanak a tökéletes informáltság feltevésén. Amint ugyanis Shaw (1974) megjegyzi és empirikus példával alá is támasztja, a potenciális migránsok jókora hányada nem tudja felmérni az elvándorlás költségeit és hasznait, ennek következtében pedig racionális költség-haszon kalkulációt sem tud végezni. Speare (1971) felmérése ugyancsak azt erősíti meg, hogy a migránsok döntő hányada gyakorlatilag minimális tudással rendlkezik a célterületi lehetőségekröl. Világos tehát, hogy a közgazdaságtudomány tökéletes racionalitási feltevése csorbul, hiszen a döntést hozók nincsenek tisztában az előttük álló opciók valamennyi aspektusával.

Valójában persze már a kockázatok modellbe építése is puhított a tökéletes racionalitás feltételezésén. Az, hogy a potenciális migráns az alternatívák várható hasznaival - például a bérnek a munkába állás valószínűségével diszkontált értékével -

\footnotetext{
10 A saját modelljével, s különösen annak formalizálásából adódó problémákkal kapcsolatos kritikákat
} Borjas (2014) foglalta össze. 
számolt, már ebbe az irányba tett elmozdulás volt. Ez pedig az egyén kockázatpreferenciáját emelte az elvándorlás fontos befolyásoló tényezői közé. Így ezen modellekben - amint arra DaVanzo (1981a) is utal - a kozkázathoz való hozzáállás a migránsok egyik szelekciós tényezőjévé vált. Mindazonáltal ez csak egy addicionális lépéssel bonyolította a modellezők előtt álló matematikai formulát, s a döntés természetének leírását nem közelítette a valósághoz. Az a feltételezés ugyanis, hogy az egyén pontosan ismeri az egyes jövőbeni kimenetek bekövetkezési valószínüségét, érdemben nem különbözik a mindentudás posztulátumától. Söt, ettől az a feltételezés sem különbözik érdemben - és nem is tünik realisztikusabbnak -, hogy a potenciális migráns valamilyen matematikai formulával leírható valószínűségeloszlást ismer, s annak centrális momentumaival képes pontos kalkulációt végezni.

A gyakorlatban az emberek nem csak a körülöttük lévő valóságról rendelkeznek hiányos információkkal, hanem a jövő lehetséges kimeneteit, és azok bekövetkezési valószínűségit sem ismerik pontosan. Döntésük során egyszerre szembesülnek tudatlansággal és - a kockázatok mellett vagy helyett - bizonytalansággal is. ${ }^{11}$

Ennek modellbe építését a migrációkutatás egyik irányzata a Stigler-féle (1989) keresési elmélet felhasználásával kívánta megoldani. Ebben a keretben a migrációhoz szükséges információ maga is egy, az egyén számára hasznos jószág, keresése azonban költséggel - direkt és lehetőségköltséggel egyaránt - jár. Így az információgyüjtés is egy optimalizációs problémává válik a migrációt fontolgató személy számára: addig érdemes folytatnia, míg a tevékenység határhaszna egyenlő nem lesz annak határköltségével. Ez a megközelítésmód jelenik meg többek között David (1974), Goodman (1981), illetve Poot (1996) munkáiban. Noha e modellek következtetései a kiinduló feltevések függvényében különbözhetnek, általánosságban elmondható, hogy az egyén információhoz való hozzáférése - amely meghatározza, hogy milyen költségek mellett tud keresni kulcsfontosságú tényezővé válik a migránsok szelekciója szempontjából. Utóbbi momentumra jelen disszertáció elméleti modelljében a tranzakciós költségek koncepciója segítségével fogunk reflektálni.

Mindazonáltal ezen irányzat gyengeségei is az irreális előfeltevésekkel hozhatók összefüggésben. Amint azt Molho (2013) kiemeli, ahhoz, hogy a potenciális migráns

\footnotetext{
11 Ezzel összefüggésben Goodman (1981) találóan két típusú hiányzó információról beszél: „megvásárolhatókról” és „meg nem vásárolhatókról”. Előbbiek közé a különböző célországokban elérhető adottságokat és lehetőségeket, utóbbiak közé pedig a bizonytalan jövő lehetséges kimeneteleit sorolja. A distinkció alapja értelemszerüen az, hogy a jövőről való információt az egyén még (idő)befektetés révén sem szerezheti meg biztosan.
} 
racionálisan döntsön a keresésre fordított idő optimális mértékéröl, előzetesen is ismernie kell - vagy legalábbis valami alapján felételeznie kell - annak legfontosabb jellemzőit, így a keresés költségét és várható hasznát vagy az elérhető bérek eloszlásának paramétereit. Ez azonban szintén távol áll az ember valóságban tapasztalt korlátozott racionalitásától. ${ }^{12}$ Emellett DaVanzo (1981a) arra hívja fel a figyelmet, hogy ezekben a modellekben az egyén kezdeti - azaz a keresés megkezdése előtti - információellátottsága ugyancsak kulcskérdés lehet: eldöntheti, hogy egyáltalán hozzálásson-e az inforációgyüjtéshez. Elöfordulhat ugyanis, hogy valakinek objektíve nézve racionális lenne - még a kereséssel is - elvándorolnia, de mivel a kezdeti tudása túlságosan szükös, ezért hozzá sem kezd az információgyűjtéshez, így a végeredmény szuboptimális lesz.

Az ismeretlen jövő kezelésének ugyancsak bevett módja a véletlen hasznossági (random utility) modellek használata, amelyekről Molho (1986) ad áttekintést, de találkozhatunk vele Borjas (1991) Huber \& Nowotny (2013), illetve Van Est (1981) munkáiban is. ${ }^{13}$ Ezek lényege, hogy az egyén által maximalizálandó hasznossági függvény két komponensre oszlik: egy objektív determinisztikus és egy véletlen részre. Ez utóbbi nem csak az empirikus becsléskor használt, meg nem figyelt, az emberek heterogenitását jelző egyedi jellemzőket sürítő „hibatagot” integrálja eleve a döntési függvényébe, hanem egyúttal az előttük álló ismeretlenségét is megtestesíti. Így ez az irányzat, szemben a neoklasszikus megközelítéssel, már nem állítja, hogy valamennyi potenciális migránsnak ugyanabba az irányba kell mozognia, ráadásul a hagyományos humántőke-elmélet eredményein is túllép azzal, hogy a látszólag homogén csoportok esetében sem prediktál hasonlókat, hanem teret enged az egyéni élethelyzetekben meglévő különbségek modellben való megjelenítésére. Ráadásul, mint Borjas (1989) kiemeli, a migrációs döntés szempontjából a véletlen tényezők országok közötti korrelációjának is fontos szerepe lehet. Mindazonáltal ahhoz, hogy a véletlen tényező kezelhető legyen az elméleti modellben, a random komponensre itt is statisztikai előfeltevéseket kell tennünk - ez azonban szintén inkább a kutató, semmint a potenciális migráns feladatának tekinthető.

\footnotetext{
12 Természetesen vannak modellek, amelyek lazítanak e feltevéseken. Maier (1985) tanulmányában például az egyén nem ismeri ugyan előre a bérek eloszlásának paramétereit, de a keresés során szerzett információk alapján lépésenként új becslést ad rá. Ez persze ugyancsak komoly kognitív képességeket kíván meg tőle. 13 A random hasznossági modellek véletlen-komponensének különböző jelentéstartalmairól, illetve ezeknek az empirikus munkákban történő megjelenéséről Huber - Nowotny (2013) ad áttekintést.
} 


\subsubsection{Behaviorista megközelítések}

A potenciális elvándorlók korlátozott informáltságának modellbe építésére a migrációs irodalom egy másik irányzata Simon $(1959 ; 1982)$ munkásságára alapozva az egyén kongitív korlátainak figyelembe vételével és a megelégedésre törekvés (satisficing) koncepciója segítségével tett kísérletet. ${ }^{14}$ Ezt a megközelítést használja Speare (1974), aki ezáltal túllép a neoklasszikus közgazdaságtani kereteken. Modelljében az egyént többféle kötelék kapcsolja a lakhelyéhez (például személyes ismeretségek, munkahely stb.), amelyek erősségét a kapcsolattal való elégedettség adja meg. Ezek összessége határozza meg az aktor általános elégedettségi szintjét, amely, ha kellően magas, akkor az egyénnek meg sem fordul a fejében az elvándorlás gondolata, még akkor sem, ha a maximalizálási paradigma alapján a status quo nem tekinthető optimálisnak. Ellenben, ha az elégedettség értéke egy bizonyos szint alá csökken, akkor számításba veszi a migráció lehetőségét. Amennyiben pedig elköteleződik a költözés mellett, akkor sem a teljes spektrum legjobb opcióját, tehát az „optimális célhelyet” kívánja megtalálni: keresési tevékenységét az első kielégítő alternatíva fellelése után befejezi. ${ }^{15}$ Mindez megfeleltethetö a simoni satisficing koncepciónak. Ezen keretek között az elégedetlenség szükséges, de nem elégséges feltétele annak, hogy valaki az elvándorlás mellett döntsön: kísérletet tehet ugyanis arra, hogy az elégedetlenségét a helyben maradás mellett korrekciókkal csökkentse (például fizetésemelést kérjen). E megközelítés magyarázattal szolgál arra, miért van a világban annyi ember, akinek bár a racionális költség-haszon kalkuláció alapján megérné a migráció, mégsem veszi azt fontolóra. A modell ráadásul a humántőke-elmélet bizonyos aspektusaira is egy új irányból ad magyarázatot. Speare szerint ugyanis az, ha valaki tudja, hogy máshol ugyanazért a munkáért többet keresnek, az elégedetlenségét növeli: tehát a bérkülönbségek is ezen a csatornán keresztül befolyásolják az elvándorlást. Az idősödés kapcsán pedig azt hangsúlyozza, hogy az örgedés nem önmagában teszi egyre immobilabbá az embereket, inkább az elégedettségük szempontrendszerét és annak küszöbértékét befolyásolja.

Speare (1974) modellje nem előzmény nélküli a migrációs irodalomban, s később sem merült feledésbe. Bár nem Simon alapján, de hasonló irányba indult el korábban

\footnotetext{
${ }^{14}$ Tekintve, hogy a Simon-féle korlátozott racionalitás koncepciójára jelen disszertációban is építünk, így annak részletes tárgyalására elméleti modellünk viselkedési elöfeltevései kapcsán a 2.1. alfejezetben kerül sor.

${ }^{15}$ A kielégítő alternatíva megtalálása után a tényleges értékelési folyamatot már Speare (1974) is egyfajta költség-haszon kalkulációként írja le. A modell ennek tükrében - jelen disszertációéhoz hasonlóan kétlépcsősnek tekinthető, melyben az első fok a maradók és a migránsok szétválasztására, a második pedig már a célterület-választásra fókuszál.
} 
Wolpert (1966) is, aki az egyén lakhelyén megélt stresszel hozta összefüggésbe a kivándorlási hajlandóság megfogalmazódását. Noha a migrációs döntés meghozatalakor az egyén ebben a modellben is az adott hely elérhető hasznosságát (place utility) veti össze az alternatíváéval, ám szerepel benne egy olyan környezeti stresszből fakadó küszöbérték, amely meghatározza, hogy az aktor egyáltalán elgondolkodik-e a költözésen. A stressznek e kritikus értéke lényegében megfeleltethető a fent tárgyalt elégedettségi küszöbnek, ugyanakkor Speare (1974) a stressz kifejezést annak negatív mentális konnotációja miatt utasította el. A Speare-féle modellt használja egy kisebb kiegészítéssel - az elégedetlenség és a költözési szándék interakcióinak használatával Bach \& Smith (1977), s ezt fejleszti tovább Landale \& Guest (1985) is. Utóbbiak szerint a szubjektív elégedettségi küszöbön túl olyan objektív korlátok is visszatarthatják az egyént az elvándorlástól, mint a pénz, az idő vagy a tudás hiánya, illetve ide sorolhatjuk akár az adott helyre vonatkozó elköteleződéseket, például az ingatlan tulajdonlását is. Noha ezen tényezők más hagyományos elméletekben is befolyásolják az egyén döntését, itt, a simoni hagyományoknak megfelelően nem csupán a maximalizációs probléma tényezőiként jelennek meg, hanem effektív korlátként, amelyek megléte esetén az egyén el sem gondolkodik az elvándorláson. Az elégedetlenség migrációs modellekbe történő további - jelen disszertáció fókuszához kevésbé kapcsolódó - beépítési kísérleteirő De Jong \& Fawcett (1981) ad áttekintést.

Bár behaviorista alapon érvelhetünk amellett, hogy a megelégedésre törekvést alkalmazó migrációs elméletek jobb leíró modellként szolgálnak az emberi viselkedés megértéséhez, ám kritika - többek között a maximalizációs paradigma oldaláról is ezekkel szemben is megfogalmazható. Molho (2013) szerint ugyanis a maximalizálás és a megelégedésre törekvés közötti dilemmáról szóló vita valójában csak szemantikai, s pusztán az információ kezelése tér el ezekben a modellekben. Hagen-Zanker (2008) szerint is lehet úgy tekinteni ezen modellekre, melyek pusztán a terminológiát cserélik fel egy újra. Előbbi azt írja, hogy a megelégedésre törekvő embert más megközelítésben egy olyan maximalizáló aktorként modellezhetnénk, aki erőteljes korlátokba ütközik az információ költségének és az elérhetőségének oldaláról. Az elégedettség és a stressz fogalmak használatával szemben is hasonló kritikákat fogalmaz meg: azok újdonságértéke valójában attól függ, hogyan definiáljuk őket. Gyakorlati oldalról pedig az mondható el Molho szerint, hogy a stressz és az elégedettség általában ugyanazon tényezők függvénye, amelyek a hasznosságot is közvetlenül befolyásolják. Hasonló jellegű kritikát Landale \& Guest (1985) megközelítésével szemben is 
megfogalmazhatunk. Ök praktikusan úgy kerülik el a migrációs döntés maximalizációs problémaként történő megfogalmazását, hogy nem építenek formalizált modellt, megelégedési koncepciójukat verbálisan írják le, és azt tesztelik empirikus eszközökkel. Mindazonáltal a modellcsalád értékelésekor Molho (2013) is elismeri, hogy a Simon-féle gondolatvilág átemelésével az érintett szerzők fontos problémára tapintottak rá, s hogy az egyén informáltságának kérdése nem kezelhető pusztán a neoklasszikus alapokon.

A simoni korlátozott racionalitás koncepciója ugyanakkor további pontokon is feszegeti a neoklasszikus döntéselmélet alapjait. Ezek egyike a nem bizonyos kimenetek modellbeli kezelésére vonatkozik. Amint ugyanis Lucas (1977) Knight (1921) alapján kiemeli, s ahogyan arra már mi is utaltunk korábban: a kockázat és a bizonytalanság nem azonos fogalmak. Előbbi esetén a döntéshozó ismerettel rendelkezik a jövőbeli kimenetelek valószínűségi eloszlásaira vonatkozóan, s ezekkel a valószínűségekkel racionális kalkulációt tud végezni. A kockázat tehát mérhető, számszerüsíthető. Bizonytalanság esetén azonban semmi ilyen jellegü információ nincs az aktor birtokában. ${ }^{16} \mathrm{Ez}$ a distinkció ugyanakkor nem jelent meg élesen a korai migrációs irodalomban: a formalizálhatóság kedvéért a modellek rendre csak a kockázatokkal számoltak. Még a humántőke-modellt kidolgozó Sjaastad (1962) is együtt használja e két fogalmat, s egyfajta diszkontáló tényezőnek tekinti őket. A kalkulációban használható diszkontrátának azonban a fentiek alapján csak a valószínűségi értékeket tartalmazó kockázatok felelnének meg.

Ennek alapján fogalmazódott meg az a simoni gondolat is, hogy kalkulatív valószínüségek hiányában az egyének optimalizáció helyett heurisztikák, hüvelykujjszabályok alapján cselekednek. Ez igaz lehet a migrációs információgyüjtés és -feldolgozás folyamatára, valamint a végső döntés meghozatalára is. Amint azt Rossi (1955 idézi: Goodman, 1981) az elvándorlás kapcsán kiemeli, az emberek a személyes ismerősöktől származó információkat tartják a legmegbízhatóbbnak, ezért elsősorban ezeket keresik. Gustavus \& Brown (1977) szerint pedig jellemzően azt a célhelyet választják, amelyről az információt személyes kapcsolat révén szerezték.

A behaviorista alapokról kifejlődő viselkedési közgazdaságtan vívmányai közül Czaika (2015) a kilátáselmélet segítségével modellezi a potenciális elvándorlók döntését. ${ }^{17}$ A Kahneman \& Tversky (1979) által kidolgozott elmélet szerint az egyén a

\footnotetext{
${ }^{16}$ A jövő kiszámíthatatlanságának fokozatairól további áttekintést ad Neszveda (2018).

17 A kilátáselmélet korábbi indirekt alkalmazásával Polgreen \& Simpson (2011) munkájában találkozhatunk. A szerzők a boldogság szerepét vizsgálták a migráció alakításában, s jutottak arra a
} 
hagyományos utilitarista megközelítéssel szemben nem az abszolút hasznosságát, hanem az abban bekövetkező változásokat értékeli. Czaika (2015) ennek a megközelítésnek a Köszegi \& Rabin-féle (2009) specifikációját használja fel, s azt feltételezi, hogy a potenciális elvándorlók a jövőre vonatkozó várakozásaikban bekövetkező változások alapján hozzák meg döntésüket. A status quot tehát a jövőre vonatkozó korábbi várakozás jeleníti meg, s a modell tartalmazza a nyereségekre és veszteségekre vonatkozó eltérő kockázatpreferenciát és a veszteségkerülést is. Emellett Czaika (2015) a viselkedési közgazdaságtan további vívmányait, így a status quo torzítást és a birtoklási hatást is annak magyarázataként említi, hogy miért maradnak helyben világszerte olyanok, akiknek a migráció egyébként racionális alternatíva lehetne. Utóbbi jelenségben az elsüllyedt költségeknek is szerepet tulajdonít, noha, azt jelen disszertációval ellentétben nem hozza összefüggésbe a specifikus beruházásokkal.

Ugyancsak a migránsok hiányos informáltságára alapozva használt egy másik viselkedésgazdaságtani vívmányt Epstein (2002; 2008), illetve Epstein \& Gang (2006). Ezen tanulmányok a csorda magatartás (herd behavior) koncepciójával (Banerjee, 1992) magyarázták, hogy a kivándorlók milyen minták alapján formálják migrációs terveiket, $\mathrm{s}$ választják ki célországukat. A horda magatartás elmélete azt implikálja, hogy mások viselkedése erősen befolyásolhatja az egyén elvándorlási szándékát, a potenciális migránsok pedig - feltételezvén, hogy elődeik tömegesen biztosan nem hozhattak rossz döntést - aszerint választanak célterületet, hogy polgártársaik előttük hova mentek nagy számban. $^{18}$

\subsubsection{A migráció új közgazdaságtana}

A nem biztos kimenetek kezelésének a problematikája adott inspirációt a migráció új közgazdaságtana (a továbbiakban: MÚK) kialakulásához is, amelynek fejlődése leginkább Stark munkásságához köthető (Stark, 1991; Stark \& Bloom, 1985; Stark \& Taylor, 1989, 1991). Ezen irányzat elemzési egysége már nem az egyén, helyette a családra tekint döntéshozó aktorként, amely a migráció lehetőségét egyfajta allokációs döntésként kezeli. Ennek során emberi erőforrásait, azaz a családtagokat úgy allokálja a

következtetésre, hogy a boldogságnak nem csak az abszolút szintje, hanem az abban bekövetkező változások is fontos befolyásoló tényezők lehetnek. A kilátáselméletet utóbbi eredményeik potenciális magyarázataként említették.

18 Megjegyzendő, hogy a hivatkozott müvekben a csorda magatartás szerepének tárgyalására az 1.1.7. alfejezetben részletezendő hálózatokkal párhuzamosan kerül sor. Epstein (2008) ezzel a hálózatok létrejöttének okára is értelmezést kíván nyújtani. A hálózati modellek ugyanis azt jól magyarázzák, hogy amikor a hálózat már müködik, miért gyakorol pozitív hatást a további potenciális migránsok döntésére, ám kialakulásuk okairól nem szól. Epstein többek között ezen ür betöltésére vállalkozott, mondván, a horda magatartást már néhány korábbi elvándorló viselkedése is beindíthatja. 
hazai, illetve külföldi munkaerö-piacok között, hogy azzal családi szinten maximalizálja a várható közös jövedelmet. Kihasználva továbbá az egyes országok gazdaságában rejlő különbözőségek adta diverzifikációs lehetőségeket, a család az előttük álló kockázatokat is minimalizálni tudja.

Fontos elörelépésnek tekinthető a MÚK részéről, hogy épít azon viselkedésgazdaságtani motívumra (Kahneman, Knetsch, \& Thaler, 1991), mely szerint az emberek nem abszolút értelemben értékelik a helyzetüket, hanem mindig valamilyen referenciaponthoz - például a társadalom más csoportjaihoz - viszonyítják azt. Ez a migráció kapcsán úgy manifesztálódhat, hogy a potenciális elvándorlók nem pusztán saját jövedelmi vagy vagyoni helyzetük, hanem a társadalmi ranglétrán elfoglalt pozíciójuk, relatív depriváltságuk alapján hozzák meg kivándorlási döntésüket (Stark \& Taylor, 1989, 1991). A szegénység tehát önmagában még nem feltétlenül ösztönöz elvándorlásra - egy gazdag társadalomban, vagy egy nagy jövedelmi egyenlőtlenségekkel terhelt országban azonban már nyomasztóbb szegénynek lenni az irányzat szerint, így ezen érintettek hajlamosabbak lehetnek a migrációra. Mindezek alapján a MÚK egyik legfontosabb állítása, hogy a migrációs folyamat a nemzetközi bérkülönbségek léte nélkül is elindulhat. Az országon belüli egyenlőtlenségek, illetve a kockázatcsökkentés mint családi cél ugyanis érdemi fejlettségbeli különbségek hiányában is ösztönözheti az elvándorlást.

Az erények mellett azonban több kritika is megfogalmazható a migráció új közgazdaságtanával szemben. Ezek egyike az elmélet alkalmazhatóságára vonatkozik. Míg a fejlődő országokból a fejlettek irányába induló migráció esetén valóban plauzibilis hipotézisnek tünhet a családi szintü kockázatminimalizálás mint migrációs ok, a fejlett országokból kiinduló elvándorlás esetén ez már kétséges lehet. Egyrészt azért, mert a nyugati individualista és atomizált társadalmi berendezkedésben, ahol a nukleáris családmodell mellett az egyedülállóság is egyre inkább jellemző, a család mint döntéshozatali egység gondolata megkérdőjelezhető. Másrészről pedig - mint azt Massey és mtsai. (1993) is említik - ezen országokban fejlett magán- és társadalombiztosítási rendszer, valamint szociális védőháló müködik, amely betölti azt a kockázatcsökkentő funkciót, amely ellen a fejlődő országok potenciális migránsai az elvándorlással tudnak védekezni. Emellett a családi szintü haszonmaximalizálás és kockázatminimalizálás koncepciója elvi szinten is kifogásolható. A Simon (1959) által felvetett kognitív korlátok ugyanis a családi szintű döntéshozatalban, amely a kollektív döntések nehézségeivel (Johnson, 1999) is terhelt, még inkább jelen lehetnek, ami a realitás oldaláról kezdheti ki ezen modellek plauzibilitását. Ebből a szempontból életszerübbnek tünhetnek DaVanzo 
(1981a), Mincer (1978) és Sandell (1977) korábbi modelljei, amelyek pusztán annyit állítanak, hogy a család akkor vándorol el együttesen, ha az így szerezhető összjövedelem nagyobb a hazainál, s az egyes családtagok esetleges alacsonyabb keresetéből származó kiesést a többiek növekménye internalizálni tudja.

Mindazonáltal a MÚK elvitathatatlan érdeme, hogy felhívta a figyelmet arra, hogy az emberek nem kizárólag saját szempontjaikat veszik figyelembe a kivándorlási döntés meghozatalakor. Az a családi és társadalmi közeg is befolyásolja őket, amelyben élnek. A családi döntéshozatalon alapuló koncepcióval azonban jelen, módszertani individualizmusra épülő disszertációban nem tudunk azonosulni. A potenciális migráns társas kapcsolatainak fontosságát, illetve a relatív pozícionálás gondolatát azonban előbbit a MÚK-hoz sorolható Foster \& Rosenzweig (2001) szerzőpároshoz hasonlóan az altruizmus motívumának segítségével - kutatásunkban is felhasználjuk.

\subsubsection{Hálózatelméletek}

A potenciális migráns döntésére nem kizárólag a vele egy háztartásban élő családtagjai, hanem más személyek is hatást gyakorolhatnak. Amint arra már utaltunk, tájékozódása során az egyén különös figyelmet szentel a rokonoktól, barátoktól érkező információkra. Ennek fontosságát a migrációs hálózatok elmélete foglalja keretbe (Gurak \& Caces, 1992; Massey, 1990a; 1990b), amely elsősorban nem a migráció kiváltó okait, hanem annak mértékének alakulását kívánja magyarázni. Az irányzat központi fogalma a kumulatív okság (cumulative causation) kifejezés, amely a migráció önerösítő és önfenntartó természetére utal. Az ugyanis, hogy egy adott társadalmon belül (vagy más megközelítésben egy adott célországban) növekszik a kivándorlók (vagy bevándorlók) száma, a migrációs hálózatok kiépülésével a többiek számára is megkönnyíti a migrációt. A migrációs hálózatok az emberek interperszonális kapcsolatára épülnek, amelyek például a kvázi-intézményesülő információs csatornákon keresztül - érdemben csökkentik a vándorlás mobilitási költségeit. A hálózatok bővülésével ezek a költségek tovább mérséklődnek, ami a kivándorlás nettó hasznainak növelésével még több személy számára teszi racionális döntéssé az elvándorlást. Így az egy idő után öngerjesztő folyamattá válik. Ráadásul a hálózat kiépülése nem csak a mobilitási költségek, hanem a bizonytalanság csökkentéséhez is érdemben hozzájárul, ami ugyancsak döntő erővel bírhat. Ezen szempontok közül a hálózatok mobilitási költség-csökkentő hatását fogjuk az intézményi közgazdaságtani megalapozottságú modellünkbe integrálni.

A migrációs hálózatok elmélete így magyarázatot nyújt arra, hogy miért növekedhetnek az áramlások még elhanyagolható, vagy éppen csökkenő nemzetközi 
bérkülönbségek mellett is. Mindazonáltal fontos látni, hogy ezen elmélet fókusza eltér a fent bemutatottakétól, s a migráció megindulásának kezdeti okait nem, csak későbbi mértékének alakulását képes magyarázni.

A hálózatok szerepét mind a közgazdasági, mind a szociológiai irodalom tárgyalja. Előbbi a hálózat által nyújtott pozitív externáliák és a hálózat növekedése nyomán endogén módon változó mobilitási költségek szerepére helyezi a hangsúlyt (Carrington, Detragiache, \& Vishwanath, 1996), illetve azt emeli ki, hogy a hálózat segítsége révén az információs költségek csökkenhetnek (Poot, 1996), a munkába állás valószínűsége pedig nőhet (Stahl, 1995).

A szociológiai irodalom ennél szélesebb körü szerepet tulajdonít a hálózatoknak. Mivel rendszerint az egyéni cselekvések társadalmi beágyazottságára és meghatározottságára helyezi a hangsúlyt, a migráció kapcsán is axiómaként kezeli, hogy a személyes kapcsolatoknak, s az erre épülö kapcsolati hálónak fontos szerepe van a migráció lefolyásában. ${ }^{19}$ Sik (2012) ezt a hálózatrendszert nevezi migrációs buroknak, amelynek az elvándorlás mint lehetőség felmerülésétől kezdve, a célországválasztáson át egészen a külföldi munkahely megtalálásáig döntő szerepe van a migráció sikerességében. Mint írja: „a hálózat nem csupán a hálózetelméletben megismert tranzakcionális költségeket csökkentő racionalitás intézménye, hanem egy nagy tehetetlenségi erejü és önálló életet élő társadalmi mechanizmus, amely több mint a benne szereplő egyének és háztartások összege, amely önálló szubkultúraként és gazdasági környezetként hosszú távon befolyásolja a benne lévők és a vele érintkezők viselkedését és korlátozottan racionális döntéseit” (Sik, 2012 145. o.). Ez a megközelítés Haug (2008) munkájában is megjelenik, aki a hálózatok növekedésével járó mobilitási költség- és kockázatcsökkenés helyett a hálózatban megjelenő társadalmi tőke bővülésére helyezi a hangsúlyt. ${ }^{20} \mathrm{~A}$ hálózat ezáltal az új környezetbe való beilleszkedésben, s az ezzel járó személyes sokkok kezelésében is segítséget tud nyújtani (Sik, 2018).

Disszertációnk egyik alapvetése, hogy a potenciális migránst a szociológiai irodalomhoz hasonlóan nem a társadalom többi tagjától szeparáltan élő individumként, hanem társas lényként kezeljük, akinek a döntésére személyes kapcsolatai és társadalmi

\footnotetext{
${ }^{19}$ Mindezek kapcsán a szociológiai irodalom nagy hangsúlyt fektet a hálózatok és a Granovetter-féle (1985) beágyazottság szerepére, azonban ezt többnyire a bevándorlók integrációja kapcsán tárgyalja, amely kívül esik disszertációnk fókuszán. A témáról jó áttekintést ad Portes \& Sensenbrenner (2007).

20 A specifikus beruházásokkal rokonítható gondolatok tárgyalásakor már hivatkoztunk Haug (2008) munkájára. Az ott hivatkozott helyszínspecifikus tőke az itt tárgyalt társadalmi tőke egy sajátos, helyben értékes fajtájának tekinthető.
} 
beágyazottsága is hatással van. Mindezt azonban nem a szociológia által felépített keretrendszerben, hanem az új intézményi közgazdaságtan fogalomkészletével értelmezzük. Így az egyén migrációs hálózatát, azt, hogy rendelkezik-e külföldi kapcsolatokkal (családtagok, barátok) az elvándorlás tranzakciós költségeit csökkentő tényezőként kezeljük, a helyben meglévő kapcsolatait, beágyazottságát pedig a korábban megtett specifikus beruházásai között tárgyaljuk.

\subsubsection{Intézményi jellegü megközelítések}

Jelen disszertáció egy intézményi közgazdaságtani megközelítést nyújt a migráció elméletéhez, ezért fontos, hogy jelezzük: a migrációkutatásban már létezik egy intézményinek nevezett irányzat (institutional theory) is. Ennek fókusza és megközelítésmódja azonban eltér jelen disszertációétól. Massey és mtsai. (1993) megfogalmazásában ugyanis azt vizsgálja, hogy a különböző - többnyire privát vagy nonprofit, de akár illegális - szerveződések hogyan épülnek rá a már meglévő áramlásokra, $\mathrm{s}$ intézményesülésük miként befolyásolja a további migráció mértékét. A vonatkozó irodalom e szerveződésekre intézményként utal, jelen disszertációban azonban North (2010) 2.2. alfejezetben ismertetendő megkülönböztetését követve ezeket nem intézménynek, hanem szervezeteknek tekintjük. E szerveződéseket az irányzat a migráns hálózatok kiegészítő, az informális hálón túli, formalizálódott komponenseként tekinti, amelyek a migrációhoz szükséges társadalmi tőke hordozóiként jelennek meg. Spaan \& van Naerssen (2017) a migráció induktorainak, segítőinek és kontrollálóinak nevezi őket. Ennek megfelelően az irányzat jobbára a szerveződések által betöltött specifikus szerepek elemzésére helyezi a hangsúlyt (Goss \& Lindquist, 1995; Massey és mtsai., 1998). Mindazonáltal tagadhatatlan, hogy ezen szervezetek akár önmagukban, akár az általuk foganatosított - formális és informális - szabályok révén a disszertációban alkalmazott megközelítésben is fontos szerepet játszhatnak. Jelen elemzés fókuszát azonban az intézmények tekintetében szélesebbre vesszük, $\mathrm{s}$ a továbbiakban intézményi megközelítés alatt az általunk használt intézményi közgazdaságtani szemléletmódot értjük.

Effajta megközelítéssel találkozhatunk Bertocchi \& Strozzi (2008) munkájában, amely a politikai intézmények minőségének a migrációra gyakorolt hatását vizsgálja. Ebben a szerzők annyiban lépnek túl a korábban ismertetett megközelítéseken, hogy a migráció-specifikus intézményeken (például bevándorlás- és állampolgárság-politikai, földvásárlási szabályok) túl az általános politikai intézmények minőségének fontosságára is felhívják a figyelmet. A tanulmány empirikus irányultsága miatt azonban az oksági 
viszony hatásmechanizmusát nem fejtik ki részletesebben, így a politikai intézmények minősége egyfajta vonzó-taszító tényezővé degradálódik, amelynek nyomán az írás leginkább utóbbi iskola keretei közé sorolható be. Hasonlókat fogalmazhatunk meg Böhme, Gröger, \& Stöhr (2019) munkája kapcsán is, ahol a politikai intézményrendszer minőségére vonatkozó indikátorok az empirikus elemzés kontrollváltozói között jelennek meg érdemi elméleti megalapozás nélkül. A politai rendszer ilyen, taszító jellegü szerepe a nem önkéntes migráció, így a menekült-áramlások elemzése kapcsán is rendre felmerül (Neumayer, 2004; Tétényi, Barczikay, \& Szent-Iványi, 2018). Amellett azonban, hogy ezek - pontosan az önkéntesség hiánya és a nyilvánvalóbb politikai kapcsolódások miatt - témájukban is távolabb esnek jelen disszertáció vizsgálatától, még elemzési szintjükben is eltérnek tőle. Így, noha állításaik hasonlóak, az áramlások mértékére fókuszáló elemzéseikben ezen makroszintü munkák sem az intézményi közgazdaságtan alapvetéseire támaszkodnak, s nem térnek ki részleteiben az egyéni szinten megjelenő ösztönzési hatásokra. Ezért ezen munkákat inkább is a push-pull irányzathoz tartozónak tekintjük.

$\mathrm{Az}$ általunk használt intézményi megközelítésben érinti ugyanakkor a migráció témáját Acemoglu, Johnson, \& Robinson (2001). Ök azonban más relációban teszik ezt: a bevándorlás hatását vizsgálják a politikai intézményekre, amelynek tárgya kívül esik vizsgálódásunk keretein.

Jelen alfejezetben érdemel említést Wang, de Graaf, \& Nijkamp (2018) munkája is, amely a kulturális különbségeknek a migrációt és a célországválasztást befolyásoló hatását tekinti át. Noha a tanulmány nem intézményi közgazdaságtani terminológiát használ, s az említett különbségek leküzdését többnyire a vándorlás költségeként kezeli, disszertációnk szempontjából fontos tényezőre mutat rá. Arra, hogy a kulturális sajátosságok, szabályok alkotta informális intézményi háló érdemi hatással bír a nemzetközi áramlások mértékére.

\subsection{9. Összegzés}

Jelen fejezetben átfogó - noha nem teljeskörü - képet adtunk arról, hogy a különböző társadalomtudományi, főként közgazdasági kötődésű elméletek milyen magyarázatokat adnak a migráció megindulására, mértékére és tendenciáira vonatkozóan. Ennek során a neoklasszikus makroökónómiai és mikroökonómiai (humán tőke) elméleteknek, a vonzás-taszítás elméletének, bizonyos továbbfejlesztett mikroökonómiai, illetve behaviorista elméleteknek, a migráció új közgazdaságtanának, hálózati és korábbi intézményeinek nevezett megközelítéseknek az áttekintésére került sor. Mindezek 
kivonatát az 1.1. táblázatban foglaljuk össze úgy, hogy abban elhelyezzük jelen disszertáció produktumát, a migráció intézményi közgazdaságtani alapú modelljét is. Az áttekintett irodalom összegző értékelésére, a föbb hiányosságok összefoglaló bemutatására az empirikus irodalmak feldolgozása után az 1.3. alfejezetben kerül sor. 
1.1. táblázat

Migrációs elméletek: összefoglalás

\begin{tabular}{|c|c|c|c|c|c|}
\hline Elmélet & $\begin{array}{l}\text { Vizsgálati } \\
\text { szint }\end{array}$ & $\begin{array}{l}\text { Elemzési } \\
\text { egység }\end{array}$ & $\begin{array}{l}\text { Magyarázandó } \\
\text { jelenség }\end{array}$ & Migráció fó okai & Főbb szerzők \\
\hline $\begin{array}{l}\text { Neoklasszikus } \\
\text { makrogazdasági elmélet }\end{array}$ & Makro & Ország & $\begin{array}{l}\text { Áramlások iránya, } \\
\text { mértéke, egyensúly }\end{array}$ & $\begin{array}{c}\text { Tőke-munka relatív nemzetközi } \\
\text { egyensúlytalansága }\end{array}$ & $\begin{array}{l}\text { Lewis, Harris \& } \\
\quad \text { Todaro }\end{array}$ \\
\hline Vonzás-taszítás elmélete & Vegyes & Áramlás & Áramlások okai & Vonzó és taszító tényezők & Ravenstein, Lee \\
\hline $\begin{array}{l}\text { Neoklasszikus } \\
\text { mikroökonómia (humántőke) } \\
\text { elmélet és továbbfejlesztései }\end{array}$ & Mikro & Egyén & $\begin{array}{l}\text { Migrációs döntés, } \\
\text { szelekció }\end{array}$ & $\begin{array}{l}\text { Egyén számára elérhető költségek és hasznok; } \\
\text { egyéni humántőke optimális hasznosítása }\end{array}$ & $\begin{array}{l}\text { Sjaastad, Todaro, } \\
\text { Borjas }\end{array}$ \\
\hline $\begin{array}{l}\text { Behaviorista megelégedési } \\
\text { modell }\end{array}$ & Mikro & Egyén & $\begin{array}{l}\text { Migránsok választása, } \\
\text { szelekciója }\end{array}$ & $\begin{array}{c}\text { Egyén elégedettsége, szubjektív észlelése és } \\
\text { értékelése }\end{array}$ & Speare \\
\hline Migráció új közgazdaságtana & Mezo & Család & $\begin{array}{l}\text { Családtagok } \\
\text { allokálása, migráció } \\
\text { alakulása }\end{array}$ & $\begin{array}{l}\text { Egyén relatív jóléte; családi szintü } \\
\text { kockázatminimalizálás }\end{array}$ & Stark \\
\hline Migrációs hálózatok elmélete & $\begin{array}{l}\text { Mezo, } \\
\text { vegyes }\end{array}$ & $\begin{array}{l}\text { Egyén, } \\
\text { hálózat }\end{array}$ & $\begin{array}{l}\text { Migráció mértékének } \\
\text { alakulása }\end{array}$ & $\begin{array}{l}\text { Kiváltó ok bármi; a hálózati hatás az áramlás } \\
\text { mértékét növeli }\end{array}$ & Massey, Sik \\
\hline $\begin{array}{l}\text { Korábbi ,intézményi” } \\
\text { megközelítés }\end{array}$ & Mezo & Szervezet & $\begin{array}{l}\text { Szervezetek szerepe a } \\
\text { migrációban }\end{array}$ & $\begin{array}{c}\text { Kiváltó ok bármi; a szervezetek létrejötte az } \\
\text { áramlás mértékét növeli }\end{array}$ & Goss \& Lindquist \\
\hline $\begin{array}{c}\text { Jelen disszertáció intézményi } \\
\text { közgazdaságtani } \\
\text { megközelitése }\end{array}$ & Mikro & Egyén & $\begin{array}{l}\text { Migrációs döntés, } \\
\text { szelekció }\end{array}$ & $\begin{array}{c}\text { Egyén számára elérhetö költségek és hasznok, } \\
\text { intézmények, tranzakciós költségek, specifikus } \\
\text { beruházások, lelki költségek }\end{array}$ & \\
\hline
\end{tabular}

Forrás: saját szerkesztés 


\subsection{Empirikus irodalmak}

A migráció befolyásoló tényezőit leíró elméleti modellek bemutatása után az ezek érvényességéről, empirikus alátámasztásáról szóló irodalmat tekintjük át. Ezt azonban mint azt korábban is jeleztük - az elméleti alfejezet felépítésétől eltérő struktúrában tesszük: az áttekintendő tanulmányokat az általuk használt adatok mérési szintjének függvényében bontjuk két részre. Ennek megfelelően először az aggregált, makroszintü (1.2.1. alfejezet), majd az egyéni jellemzőket tartalmazó, mikroszintű (1.2.2. alfejezet) adatokat használó vizsgálatokat mutatjuk be. Erre a bontásra azért van szükség, mert a megfelelő egyéni adatok hiányában gyakori, hogy a mikroszintű elméleteket is aggregált adatok segítségével tesztelik a szerzők.

A makroadatokat használó tanulmányok elsősorban az áramlások irányának, mértékének és a makrokörnyezetben megjelenő kiváltó okok elemzését célozzák. Az egyéni adatokkal végzett kutatások pedig elsősorban a migránsok szelekciójának, az elvándorlási döntésben számításba vett egyedi tényezők vizsgálatára alkalmasak. A verbális áttekintés során feldolgozott irodalmak fő következtetéseiről az alfejezetek végén egy-egy összefoglaló táblázatot fogunk közölni.

\subsubsection{Makroszintü vizsgálatok}

Amint azt az 1.1. alfejezetben bemutattuk, a migráció egyik mozgatórugója a bérkülönbségek léte. Az egyes területek, országok bérszínvonala pedig általában szoros korrelációt mutat azok általános fejlettségét leíró további mutatókkal. Mindezeknek a migrációs folyamatokban betöltött szerepét az empirikus irodalmak is rendre igazolták.

Krugman \& Bhagwati (1976) tizenkettő korai, aggregált adatokat használó empirikus tanulmányt tekintett át, melyek a belső migráció esetén - egy kivétellel rendre igazolták a bérszínvonal szignifikáns és a várakozásoknak megfelelő előjelü szerepét a küldő és a célterületeken egyaránt. Hasonló áttekintést közöl hasonló eredménnyel a belső migráció kapcsán Bauer \& Zimmermann (1995) is.

Mindezen túl a migráció célterületein elérhető magasabb bérek szignifikáns szerepét számos, különböző elméleti hátteret, módszertant és mintát használó makroszintű vizsgálat eredménye igazolta. Dorigo \& Tobler (1983) a push-pull elmélet tesztelésére épített gravitációs modellt ${ }^{21}$, amellyel a az Egyesült Államokbeli belső

\footnotetext{
${ }^{21}$ A gravitációs modellek elméleti szinten is használatosak a migrációs irodalomban, mivel azonban ezek megközelítésmódja kívül esik jelen disszertáció logikai vonulatán, tárgyalásukra a migrációs elméleteket bemutató részben nem tértünk ki. Tekintve azonban, hogy megállapításaik több empirikus munka alapját adják, röviden itt ejtünk szót róluk. Kim \& Cohen (2010) megfogalmazásában a gravitációs modellek főbb predikciói a következők: i) a nagyobb népességü országok több migránst bocsátanak ki a kisebb
} 
áramlások mértékét becsülték, s e modell outputjait vetették össze az tényleges állami adatokkal. Eredményeik megerősítik a célállamok bérszínvonalának jelentőségét. Hartog \& Vriend (1989) Hollandia, míg Katseli \& Glystos (1989) Görögország esetében vizsgálta a kivándorlási rátákra ható tényezők szerepét. Utóbbiak a migráció mikroökonómiai elméletéből kiindulva OLS segítségével, előbbiek pedig a mikro- és makroökonómiai megfontolások együttes felhasználásával, idősoros módszerrel támasztották alá a célországok bérszínvonalának befolyásoló erejét. Geary \& Ó Gráda (1989) az ír-brit relációt vizsgálta, s idősoros, valamint instrumentális változót használó regresszió segítségével jutott azonos eredményre. Ugyanezt Lundborg (1991) a humántőke-elmélet talajáról, a látszólag össze nem függő regressziók (seemingly unrelated regressions, SUR) módszerével a skandináv országok migrációs rátái kapcsán erősítette meg. A fogadó ország béreinek proxyjaként az egy főre eső GDP-t használva vegyes elméleti háttérrel Jennissen (2003) idősoros módszerrel a nyugat-európai, Mayda (2010) panelmodell segítségével az OECD országok vándorlási rátája, Sprenger (2013) ugyancsak panelmódszerrel az EU-n belüli áramlások, Palmer \& Pytlikova (2015) pedig egy OLS és egy GMM (momentumok általános módszere) modell felhasználásával az Unión belüli bilaterális migrációs ráták esetén támasztotta alá a változó fontosságát.

Negatív irányú kapcsolatra utaló empirikus eredménnyel csak Jenkins (1977) munkájában találkozhatunk, aki a vonzás-taszítás elméletét Mexikó és az Egyesült Államok viszonylatában tesztelte. Eredményének általánosíthatósága azonban több szempontból is megkérdőjelezhető. Vizsgálata ugyanis az idősorok egyszerü korrelációanalízisére épült, így a bérek és a migráció kapcsolatában nem tudott kontrollálni további tényezőkre (pl. az amerikai gazdaság további vonzó tényezőire vagy a migrációs politika szigorúságának változására). Továbbá elemzését nem a gazdaság egészére végezte, a korreláció-analízisben kizárólag mezőgazdasági dolgozók bérével számolt, amely csak részleges képet ad a migráció jelenségéről, s változása még az egyéb szektorok, valamint a nemzetgazdasági átlag bérszínvonalának mozgásával sem feltétlenül esik egybe.

Az elméletek szerint a származási országok bérszínvonala ugyancsak fontos tényező a migráció alakulásában, amit Jenkins (1977), Dorigo \& Tobler (1983), Katseli \& Glystos (1989), Geary \& Ó Gráda (1989), valamint Lundborg (1991) empirikus vizsgálatai is alátámasztottak. A push-pull megközelítésre alapozva, a pakisztáni kivándorlók számát idősoros módszerrel vizsgálva Ahmad és mtsai. (2008) is hasonló

népességűeknél; ii) a nagyobb népességü országok több bevándorlót vonzanak; és iii) nagyobb távolságok esetén a várható áramlások mértéke is kisebb. 
eredményre jutottak, Kureková (2013) pedig a kelet-közép-európai országok munkaerejének kivándorlási rátája kapcsán, korreláció-analízis révén bizonyította ezt. A bérek proxyjaként ismét a GDP-adatokat használva Sprenger (2013), valamint Palmer \& Pytlikova (2015) eredményei is a fentieket erősítik meg.

A küldő országok bérszínvonala kapcsán ugyanakkor Faini \& Venturini (2010) vegyes eredményeket találtak. A szerzők dél-európai országok bruttó flow adatokból számított kivándorlási ráták kapcsán panelmódszerrel jutottak arra, hogy ugyan a gazdagabb küldő országok bérszínvonalának növekedése csökkenti az elvándorlást, ám a szegény országok esetén a kapcsolat fordított. Ezt azzal magyarázták, hogy a bérek növekedése ezen társadalmakban első körben inkább lehetőséghez juttatja a migrációt fontolgatókat. Ezen tanulmány tehát a származási országok bérszínvonalának és kivándorlási rátájának kapcsolatát egy fordított U-alakú görbével írja le. Ugyanezt erősítetik meg Pedersen, Plytlikova, \& Smith (2008) eredményei is, akik a push-pull elmélet alapján az OECD-országokba történő vándorlást vizsgálták dinamikus panelmodellel.

A származási és a célország egymáshoz viszonyított bérszínvonalának - azaz a relatív bérszínvonalnak - a kivándorlásra gyakorolt hatását is többen tesztelték. Walsh (1974) humántőke- és push-pull elméletre alapozott tanulmányában Írország és az Egyesült Királyság viszonyánban OLS technikával igazolta a bérszínvonalbeli különbségek és az áramlások mértéke közötti pozitív kapcsolatot. Ezt az összefüggést erősítette meg Jenkins (1977), illetve Geary \& Ó Gráda (1989) is. A pozitív kapcsolat létét támasztotta alá Finnország és Svédország viszonyában a humántőke elmélet bázisán pooled OLS segítségével vizsgálódó Erikson (1989), valamint a gravitációs modelljét a nyugat-európai országok bevándorló állományán OLS-sel tesztelő Molle \& van Mourik (1989) is. Ugyancsak lineáris regresszió segítségével tesztelte a neoklasszikus közgazdaságtan predikcióit a közép-európai országok mintáján Fassmann \& Münz (1997), s erősítette meg, hogy a nagyobb bérkülönbségek nagyobb vándorlási áramlásokat eredményeznek. A humántőke elméletből kiindulva Hatton (2005) véletlenhatású panelmodell segítségével egyesült királysági adatok felhasználásával, Clark, Hatton, \& Williamson (2007) pedig fix-hatású panelmodell révén amerikai adatokon jutott ugyanerre az eredményre. Bertocchi \& Strozzi (2008) vegyes elméleti háttérrel 1870 és 1910 közötti adatokkal, válogatott nyugat-európai és észak-amerikai országok mintáján panel-módszerekkel igazolta a bérkülönbségek szignifikáns szerepét. Az EU-s országok tekintetében ugyanerre az eredményre jutott a bérek proxyjaként GDP-adatokat 
és panelmódszereket használva Capuano \& Migali (2017) is. A pozitív irnyú kapcsolat létét Faini \& Venturini (2010) is megerősítette.

A fentiekkel ellentétes, negatív irányú kapcsolatra utaló eredmény Grogger \& Hanson (2011) regressziós modelljeinek egyik, logaritmizált bérkülönbségeket használó specifikációiban figyelhető meg (az egyszerü különbséget tartalmazó modellben a változó együtthatója pozitív, de nem szignifikáns). Itt a szerzők OECD országok kivándorlási rátái segítségével a Borjas-féle szelekciós modell implikációit kívánták tesztelni, a negatív együttható megjelenését pedig a mobilitási költségekre való kontrollálás hiánya miatti kihagyott változók okozta torzítással, valamint az adatokban meg nem jelenő negatív szelekció hiányával magyarázták. Negatív irányú és nem szignifikáns kapcsolatról számolt be Waldorf \& Esparza (1988) is, akik négy különböző európai országból az NSZK-ba történő munkaerő-migráció időbeli alakulását vizsgálták. $^{22}$ Az országok idősoraira külön-külön futtatott, s egymástól is különböző specifikációjú modelljeikben azonban mindössze a relatív bér- és munkanélküliségi szint szerepelt magyarázóváltozóként, így az erősen korlátozottnak tekinthető, ami magyarázattal szolgálhat az irodalom döntő többségében tapasztaltaknak ellentmondó eredményeikre.

A nemzetgazdaságok munkaerő-igénye, s ennek pandantjaként a migráns munkába állásának valószínűsége ugyancsak fontos befolyásoló tényezőként jelent meg a migrációs elméletekben, amely faktorokat az empirikus kutatások rendre a munkanélküliség mértékével proxyzták. A célterületek munkanélküliségi szintje és az oda áramló migráció mértéke között az irodalom egyhangúan igazolta a negatív irányú kapcsolat létét. Jenkins (1977), Dorigo \& Tobler (1983), Hartog \& Vriend (1989), Katseli \& Glystos (1989), Lundborg (1991), Jennissen (2003), Hatton (2005), Faini \& Venturini (2010), Sprenger (2013), valamint Palmer \& Pytlikova (2015) hivatkozott tanulmányai mind erre szolgáltatnak empirikus bizonyítékokat. Tétényi, Barczikay, \& Szent-Iványi (2018) szerint ráadásul ez az összefüggés még menekültek esetén is fennáll. Munkájukban ezt a push-pull irányzatból kiindulva, panel-módszerekkel a Magyarországra beérkező menedékkérelmekre vonatkozó adatok segítségével igazolták.

\footnotetext{
${ }^{22}$ Waldorf \& Esparza (1988) kutatásukat a humántőke- és a duális munkaerőpiacok elméleti talaján végezték. Utóbbit az elméleti áttekintő részben nem tárgyaltuk, mivel a megközelítésmód logikája kívül esik jelen dolgozat gondolatmenetén. Massey és mtsai. (1993) alapján itt annyi megjegyezhető, hogy a duális munkaerőpiacok elmélete főként az egyes országok munkaerő-keresletére fókuszál, ami - a strukturális és fejlettségi különbségekböl adódóan - egyfajta szívó hatásként határozza meg a nemzetközi migráció irányát és mértékét.
} 
Ezzel párhuzamosan a származási országok magasabb munkanélküliségi szintje a gazdaságban meglévő munkaerő-feleslegre utalhat, arra, hogy az egyén számára is nehezebb lehet megfelelő munkát találni, s mindez egyfajta taszító tényezőként jelentkezhet az elvándorlást fontolgató munkaerő számára. E hipotézist Dorigo \& Tobler (1983), Eriksson (1989), Katseli \& Glystos (1989), Lundborg (1991), Fassmann \& Münz (1997), Ahmad és mtsai. (2008), Faini \& Venturini (2010), Kureková (2013), Sprenger (2013), Palmer \& Pytlikova (2015) vizsgálatai támasztják alá.

A küldő ország munkanélküliségi szintje és a kivándorlás mértéke között csak Stark, Micevska, \& Mycielski (2009) talált negatív irányú kapcsolatot, akik a MÚK elméleti talaján állva fix-hatású panelmodell segíségével elemezték a lengyelországi régiók emigrációs folyamatait. A szokatlan eredményt azonban strukturális okokkal magyarázták: az érintett munkanélküliek ugyanis - a szocialista rendszer „örökségeként” - olyan típusú képzettségekkel rendelkeztek, amellyel külföldön sem tudnának munkát találni. Így esetükben humán tőkéjük gyenge minősége jelentette a visszatartó erőt a kivándorlástól, s a magas munkanélküliség okozata, nem pedig oka volt ennek.

A munkanélküliség fentiekkel konzisztens szerepét erősítették meg Walsh (1974) és Waldorf \& Esparza (1988) és Lundborg (1991) hivatkozott elemzései is, akik a küldő és a fogadó ország relatív munkanélküliségi szintje és a vándorlások mértéke között találtak pozitív irányú szignifikáns kapcsolatot. A két változó között ellentétes irányú kapcsolatot csak Geary \& Ó Gráda (1989) mért az Írországból az Egyesült Királyságba történő migrációt vizsgáló empirikus modelljük első specifikációjában. Miután azonban modelljüket újraspecifikálták és a várható relatív bérek változójában számoltak a munkanélkülivé váláskor esedékes járadékokkal is, már az elmélettel konzisztens eredményekre jutottak.

A piaci tényezők mellett a nettó közszolgáltatási szintet - $\mathrm{s}$ ezáltal az egyén jóléti szintjét - és az intézményi működés nyomán jelentkező adminisztratív terheket befolyásoló közpilitikai jellegü faktorok fontosságát ugyancsak több empirikus vizsgálat alátámasztotta. Geary \& Ó Gráda (1989) azt mutatta meg, hogy az adó- és a jóléti rendszer a potenciális migránsok várható jövedelmén keresztül befolyásolja a migrációs trendeket, Tétényi, Barczikay, \& Szent-Iványi (2018) a menedékkérők esetén jutott hasonló eredményre, míg Lundborg (1991) a munkanélküli járadékok célországbeli, illetve a küldőkhöz viszonyított relatív nagyságának befolyásoló erejét igazolta. Kureková (2013) a származási országok jóléti rendszereinek (jóléti, szociális védelmi és munkanélküliségi 
kiadások), Palmer \& Pytlikova (2015) pedig a jóléti kiadások kapcsán bizonyította, hogy hatással vannak a migráció alakulására.

Pânzaru (2013) közép-kelet-európai országok migrációs flow adatain panelmódszerrel jutott arra az eredményre, hogy a közpolitika és az intézményi működés minősége (így az üzleti és munkaerőpiaci szabályozás, valamint az igazságszolgáltatás továbbá a jogrendszer működése) nem befolyásolja a vándorlások mértékét. Ebből azt a következtetést vonta le, hogy az említett tényezők helyett elsősorban a gazdasági tényezők dominánsak a migráció mozgatásában. Tekintve azonban, hogy empirikus modelljében ezekre a változókra nem kontrollált, így módszertana, $\mathrm{s}$ ezáltal az eredményei - valamint az abból levont következtetések - erősen megkérdőjelezhetőek. Bertocchi \& Strozzi (2008) ugyanakkor szignifikáns kapcsolatot talált az intézmények minősége és a migráció alakulása között. Tétényi, Barczikay, \& Szent-Iványi (2018) pedig a származási ország politikai rendszere kapcsán arra jutott, hogy elnyomás esetén kevesebb menekült tud távozni onnan, az erőszakos konfliktusok jelenléte azonban érdemi taszító hatást jelent.

A költségek migrációs döntésekben betöltött szerepe empirikusan nehezen mérhető, ám az általánosan elmondható, hogy ezek mértéke távolabb lévő országok esetén jellemzően nagyobb (gondolva akár az utazás, költözés és a kapcsolattartás terheire is). Ennek megfelelően a makroszintü adatokkal dolgozó vizsgálatok a költségek mértékét rendre a küldő és a fogadó terület közötti távolsággal mérik. Dorigo \& Tobler (1983), Molle \& van Mourik (1989), Lundborg (1991), Fassmann \& Münz (1997), Clark, Hatton, \& Williamson (2007), Pedersen, Plytlikova, \& Smith (2008), Mayda (2010), Grogger \& Hanson (2011), Sprenger (2013), Palmer \& Pytlikova (2015), Capuano \& Migali (2017), illetve Tétényi, Barczikay, \& Szent-Iványi (2018) elemzései rendre abba az irányba mutatnak, hogy a távolság és a migráció mértéke között szignifikáns negatív irányú kapcsolat van. Emellett Sprenger (2013) tanulmányában az országok közötti szomszédosság dummy változójának szignifikáns volta is a könnyebb megközelíthetőséget, átjárhatóságot és ezzel együtt az „olcsóbb” migráció lehetőségét jelzi.

A migrációs hálózatok megléte ugyancsak hozzájárulhat a vándorlási költségek csökkentéséhez. Ezt az összefüggést is számos empirikus elemzés alátámasztotta. E vizsgálatok a hálózatok létének proxyjaként rendre a célországban tartózkodó migráns populáció méretét vagy az előző időszakban odavándorolt személyek számát használták és kivétel nélkül szignifikáns pozitív irányú kapcsolatot találtak az adott időszaki 
migráció nagyságával. Ezek az eredmények Lundborg (1991), Jennissen (2003), Hatton (2005), Clark, Hatton, \& Williamson (2007), Pedersen, Plytlikova, \& Smith (2008), Faini \& Venturini (2010), Mayda (2010), Sprenger (2013), Palmer \& Pytlikova (2015), Capuano \& Migali (2017), illetve Tétényi, Barczikay, \& Szent-Iványi (2018) hivatkozott tanulmányaiban jelentek meg.

Azt, hogy a nyelvtudás, az idegen nyelv ismerete költségcsökkentő - vagy éppen a humántőke hasznosíthatóságát növelő - tényező lehet a potenciális migránsok számára, szintén több empirikus vizsgálat bizonyította. Clark, Hatton, \& Williamson (2007) eredményei azt mutatják, hogy a angolnyelvü országokból ceteris paribus szignifikánsan többen vándoroltak az USA-ba, mint máshonnan. ${ }^{23}$ Grogger \& Hanson (2011) a célországok tekintetében mutatta meg, hogy az anglofon államok vonzóbbak a migránsok számára. Sprenger (2013) azt igazolta, hogy a származási ország lakosságának idegen nyelvismerete befolyásolja az egyes áramlások alakulását, emellett pedig a nyelvi közelség és a migráció mértéke között is szignifikáns kapcsolatot talált. Utóbbit Palmer \& Pytlikova (2015) is megerősítette.

A külföldi munkavállalást és letelepedést a bevándorláspolitikai és a kapcsolódó munkaerőpiaci szabályok is megnehezíthetik, amelyek kezelését és leküzdését ugyancsak a migráció költségeiként értelmezhetünk. Molle \& van Mourik (1989) eredményei szerint a migráció mértéke és a bevándorláspolitika szigorúsága negatív irányú kapcsolatban áll egymással. A bevándorlási és menedékjogi rendszer müködése, szigorúsága Tétényi, Barczikay, \& Szent-Iványi (2018) elemzése szerint a menedékkérök döntését is befolyásolja. Grogger \& Hanson (2011), Sprenger (2013) a szabad nemzetközi mozgás intézményének (Schengen-tagság, vízumkényszer hiánya), Capuano \& Migali (2017) pedig a képzettségek elismerésének a meghatározó szerepét igazolták. Fassmann \& Münz (1997) pedig együttjárást talált ugyan a bevándorláspolitika szigorodása és a bevándorlás növekedése között, azonban kiemelték, hogy ez inkább fordított irányú kapcsolatotra utal: valójában a növekvő bevándorlás lehetett az oka a szigorodó törvénykezésnek.

Nem csak a fogadó ország formális szabályainak leküzdése jelenthet akadályt - s ezáltal mobilitási költséget - a migránsok számára, hanem az informális intézményi különbségek áthidalása is. Ezt a hipotézist Molle \& van Mourik (1989) vizsgálata igazolja, ám Sprenger (2013) nem talált szignifikáns kapcsolatot az egyes országok vallási és kulturális távolsága, valamint a köztük végbemenő migráció mértéke között.

${ }^{23}$ Megjegyzendő, ez az eredmény nem kizárólag a nyelvtudás meghatározó szerepére, hanem a kultúrák közelségének fontosságára is rámutat. 
Utóbbira magyarázat lehet, hogy Sprenger (2013) vizsgálata EU-tagállamokra fókuszált, ahol ezek - kontrollálva ráadásul a nyelvi különbségekre - lényegesen kisebbek, mint globális viszonyban.

A gyarmati múlt fontos forrása lehet az országok kultúrájának „közelségének”, s ezáltal pozitív hatása lehet a bilaterális migráció alakulására. Ebből kiindulva a gyarmati kötelékek szerepét Grogger \& Hanson (2011) megerősítette, Mayda (2010) azonban nem talált szignifikáns kapcsolatot a változó és a migráció mértéke között. Utóbbira ugyancsak az OECD országok mintájának sajátossága adhat magyarázatot. Szintén az országok közötti közelség és kapcsolódások - adott esetben pedig akár a hálózatok - proxyjaként szolgálhatnak a bilaterális külkereskedelmi kapcsolatok is, amelyeknek az áramlásra gyakorolt pozitív hatását Fassmann \& Münz (1997) igazolta.

A korábban tárgyalt makrogazdasági mutatókon túl az infláció mértéke említendő még, amely a különböző országokban uralkodó bizonytalanság proxyajként szolgálhat. Tekintve, hogy utóbbi kétségkívül befolyásolhatja az egyén jövőjének tervezhetőségét, a magas infláció egyfajta push faktorként is müködhet. Ennek szignfikáns hatását Ahmad és mtsai. (2008) eredményei igazolják.

Ugyancsak taszító tényezőként hathat az, ha egy országban nagy az egyenlőtlenségek mértéke, hiszen az - mint azt a MÚK elmélete kimondja - fokozottan növeli a szegények depriváltság-érzetét. Ezt, az egyenlőtlenségek és a migráció mérétéke közötti pozitív kapcsolatot Hatton (2005), Clark, Hatton, \& Williamson (2007), Stark, Micevska, \& Mycielski (2009) és Mayda (2010) vizsgálatai támasztják alá.

A humántőke elmélet egyik fontos következtetése volt, hogy a fiatalabb személyek hajlamosabbak lehetnek az elvándorlásra. Noha e hipotézis empirikus tesztelésére álláspontunk szerint nem az aggregált adatokat használó vizsgálatok a legalkalmasabbak, Mayda (2010) eredményei összhangban vannak az elmélettel. Vizsgálata alapján elmondható, hogy azon származási országokban, ahol a fiatal népesség aránya magasabb volt, ceteris paribus nagyobb kivándorlási rátát figyelhetünk meg. Bertocchi \& Strozzi (2008) vizsgálata szintén erre az összefüggésre jutott. A humántőke elmélet másik lényeges predikciója a képzettségek és az elvándorlás valószínűsége közötti pozitív irányú kapcsolatra vonatkoztak. Ezt a makroszintű adatokat használó vizsgálatok közül Jennissen (2003) eredményei alátámasztják, ám Sprenger (2013) vizsgálatának egyes modellspecifikációi, valamint Palmer \& Pytlikova (2015) elemzése megcáfolják. Utóbbiakból azonban hiba - ökológiai tévkövetkeztetés - lenne konklúziót vonni: az ugyanis, hogy a magasabb átlagos képzettségi szinttel rendelkező országokból 
ceteris paribus kevesebben vándorolnak el, nem jelenti azt, hogy ténylegesen a magas képzettségüek azok, akik a kivándorlás mellett döntenek. E hipotézis empirikus tesztelése kapcsán tehát a következő alfejezetben bemutatásra kerülő mikroszintü adatokat használó tanulmányok tekinthetők irányadónak.

Összességében tehát az látható, hogy az aggregált adatokat használó empirikus tanulmányok rendre igazolják az 1.1. alfejezetben bemutatott elméletek által fontosnak tartott makrotényezők befolyásoló szerepét. Ezek a tényezők - amelyek áttekintő összefoglalását az 1.2. táblázat tartalmazza - nagymértékben hozzájárulhatnak ahhoz, hogy megértsük az országok közötti áramlások irányát és mértékét, az egyéni szintű szelekciós tényezőkről azonban csak nagyon korlátozott képet adnak. Utóbbiakról a következő alfejezetben értekezünk részletesen. 


\section{2. táblázat}

Az 1.2.1. alfejezetben feldolgozott makroszintű irodalmak empirikus eredményeinek áttekintése

\begin{tabular}{|c|c|c|c|}
\hline Forrás & Elméleti alap & Módszer & Minta \\
\hline Ahmad és mtsai. (2008) & push-pull & idősoros & Pakisztán \\
\hline Bertocchi \& Strozzi (2008) & vegyes & panel (pooled, FE, RE, IV) & Európa, Észak-Amerika \\
\hline Capuano \&Migali (2016) & - & panel & EU \\
\hline Clark, Hatton \&Williamson (2007) & humántőke elmélet & panel (FE) & USA (cél) \\
\hline Czaika (2015) & behaviorista & dinamikus panel & Németország (cél) \\
\hline Delbecq \& Waldorf (2010) & humántőke elmélet & logit & EU \\
\hline Dorigo \& Tobler (1983) & push-pull & modellezés & USA államok \\
\hline Eriksson (1989) & humántőke elmélet & pooled keresztmetszeti & Finnország - Svédország \\
\hline Faini \& Venturini (2010) & behaviorista & panel & Dél-Európa \\
\hline Fassmann \& Münz (1997) & neoklasszikus (makro és humántőke) & OLS & Közép-Európa \\
\hline Geary \& Ó Gráda (1989) & - & IV regresszió & Írország - Egyesült Királyság \\
\hline Grogger \& Hanson (2011) & humántőke elmélet (Borjas-féle szelekció) & OLS & OECD országok (cél) \\
\hline Hartog \& Vriend (1989) & neoklasszikus (makro és humántőke) & idősoros & Hollandia \\
\hline Hatton (2005) & humántőke elmélet & panel (RE) & Egyesült Királyság \\
\hline Jenkins (1977) & push-pull & korreláció analízis & Mexikó - USA \\
\hline Jennissen (2003) & vegyes & idősoros & Nyugat-Európa \\
\hline Katseli \& Glytsos (1989) & humántőke elmélet & OLS & Görögország - Németország \\
\hline Kim \& Cohen (2010) & gravitációs modell & panel & fejlett országok \\
\hline Kureková (2013) & - & korreláció analízis & Közép-Kelet-Európa \\
\hline Lundborg (1991) & humántőke elmélet & SUR regresszió & skandináv országok \\
\hline Mayda (2010) & humántőke (push-pull) & panel & OECD országok \\
\hline Molle \& Mourik (1989) & gravitációs modell (push-pull) & OLS & Nyugat-Európa (cél) \\
\hline Palmer \& Pytliková (2015) & vegyes & panel (OLS és GMM) & EU \\
\hline Panzaru (2013) & vegyes & panel & Közép-Kelet-Európa \\
\hline Pedersen, Pytlikova \& Smith (2008) & push-pull & dinamikus panel & OECD országok (cél) \\
\hline Sprenger (2013) & vegyes & panel & EU \\
\hline Stark, Micevska \& Mycielski (2009) & MÚK & panel (FE) & Lengyelország \\
\hline Tétényi, Barczikay \& Szent-Iványi (2018) & push-pull & panel (pooled, FE, RE) & Magyarország (cél) \\
\hline Waldorf \& Esparza (1988) & humántőke-, duális munkaerőpiacok elmélete & OLS & Nyugat-Európa \\
\hline Walsh (1974) & humántőke elmélet, push-pull & OLS & Írország - Egyesült Királyság \\
\hline
\end{tabular}


1.2. táblázat (folyt.)

\begin{tabular}{|c|c|c|c|c|c|c|c|c|c|c|c|c|c|c|c|c|}
\hline Forrás & Függő változó & $I_{j}$ & $I_{i}$ & $\Delta I$ & $U_{j}$ & $U_{i}$ & $\Delta U$ & $P P$ & $D$ & Net & $L$ & $I P$ & $C D$ & $I E$ & $E d$ & $O$ \\
\hline Ahmad és mtsai. (2008) & kivándorló flow & & - & & & + & & & & & & & & & & infláció: + \\
\hline Bertocchi \& Strozzi (2008) & bruttó migrációs ráták átlaga & & & + & & & & & & & & & & & & kor: -; Intézmények: + \\
\hline Capuano \&Migali (2016) & migrációs ráta & & & + & & & & & - & + & & - & & & & \\
\hline Clark, Hatton \&Williamson (2007) & bevándorlási ráta & & & + & & & & & - & + & + & & & + & & \\
\hline Czaika (2015) & migrációs flow & & & + & - & & & & & + & & - & & & & Kilátás: + \\
\hline Delbecq \& Waldorf (2010) & migráns stock és flow & + & - & + &,+- & & & & - & + & &,- 0 & & & & \\
\hline Dorigo \& Tobler (1983) & áramlások & + & - & & - & + & & & - & & & & & & & \\
\hline Eriksson (1989) & nettó migrációs ráta flow & & & + & & + & & & & & & & & & & \\
\hline Faini \& Venturini (2010) & bruttó flow kivándorlási ráta & &,+- & + & - & + & & & & + & & & & & & \\
\hline Fassmann \& Münz (1997) & bevándorlási flow & & & + & & + & & & - & & & + & & & & Külker.: + \\
\hline Geary \& Ó Gráda (1989) & migrációs flow & + & - & + & & &,+- & + & & & & & & & & \\
\hline Grogger \& Hanson (2011) & kivándorló stock & & & - & & & & & - & & + & - & & & & Gyarmat: + \\
\hline Hartog \& Vriend (1989) & kivándorlási ráta & + & & & - & & & & & & & & & & & \\
\hline Hatton (2005) & migrációs flow & & & + & - & & & & & + & & & & + & & \\
\hline Jenkins (1977) & migrációs ráta & - & - & + & - & & & & & & & & & & & \\
\hline Jennissen (2003) & nettó flow migrációs ráta & + & & & - & & & & & + & & & & & + & \\
\hline Katseli \& Glytsos (1989) & kivándorlási ráta & + & - & & - & + & & & & & & & & & & kor: -(?) \\
\hline Kim \& Cohen (2010) & migrációs flow & & & & & & & & & & & & & & & \\
\hline Kureková (2013) & kivándorlási ráta (munkaerő) & & - & & & + & & + & & & & & & & & \\
\hline Lundborg (1991) & migrációs ráták & + & - & & - & + & - & + & - & + & & & & & & \\
\hline Mayda (2010) & bilaterális flow migrációs ráták & + & & & & & & & - & + & & & & + & & Kor: - \\
\hline Molle \& Mourik (1989) & migráns stock & & & + & & & & & - & & & - & - & & & \\
\hline Palmer \& Pytliková (2015) & bilaterális flow migrációs ráták & + & - & & - & + & & + & - & + & + & & & & - & \\
\hline Panzaru (2013) & migrációs flow & & & & & & & 0 & & & & & & & & \\
\hline Pedersen, Pytlikova \& Smith (2008) & migrációs flow & &,$- \cap$ & & & & & & - & + & & & & & & \\
\hline Sprenger (2013) & migrációs flow & + & - & & - & + & & & - & + & + & - & 0 & &,- 0 & \\
\hline Stark, Micevska \& Mycielski (2009) & flow kivándorlási ráta & & & & & - & & & & & & & & + & & \\
\hline Tétényi, Barczikay \& Szent-Iványi (2018) & menedékkérő flow & & & & - & & & + & - & + & & - & & & & Politika: - \\
\hline Waldorf \& Esparza (1988) & migrációs flow & & &,$-(0)$ & & & - & & & & & & & & & \\
\hline Walsh (1974) & bruttó migrációs flow & & & + & & & - & & & & & & & & & \\
\hline
\end{tabular}




\subsubsection{Mikroszintủ vizsgálatok}

A mikroszintủ adatokat használó kutatások előnye, hogy az egyedi jellemzők alapján segítenek megérteni, mely tulajdonságokkal rendelkező személyek hajlamosabbak inkább az elvándorlásra, s ezáltal közelebb visznek a migráció okainak és befolyásoló tényezőinek megértéséhez. Az alábbiakban ilyen vizsgálatok eredményeinek bemutatására kerül sor. Ezek többnyire a humántőke elméletből indulnak ki, így az itt ismertetendő munkák esetében csak az ettől való eltérést emeljük ki.

A mikroszintü vizsgálatok megerősítik az aggregált adatokkal dolgozó szerzők és a korábban bemutatott elméletek implikációit az egyéni jólétet meghatározó bérek és a migráció kapcsolatában. Geis, Uebelmesser, \& Werding (2013) négy fejlett ország mikroadatai segítségével multinomiális logisztikus regressziót használva elemezték a migránsok célország-választásának befolyásoló tényezőit, s pozitív kapcsolatot találtak a fogadó ország bérszínvonala és az oda áramló munkaerő mértéke között. Drinkwater (2003) az EU-csatlakozás előtt álló kelet-közép-európai országok esetén ordered probit modellel - proxyként az egy före eső GDP értékeket használva - talált szignifikáns negatív kapcsolatot a küldő ország bérszínvonala és az adott állam polgárainak migrációs hajlandósága között. A származási ország alacsony bérszínvonalának az elvándorlási szándék erősödésére gyakorolt hatását logit modellekkel szintén EU-s mintákon Fouarge \& Ester (2008), Zaiceva \& Zimmermann (2008a) ${ }^{24}$, illetve lineáris regressziót és Kárpátmedencei adatokat használva Örkény (2003a) is megerősítették. Speare (1971) pedig taiwani mikroadatok felhasználásával és többváltozós regresszió segítségével talált pozitív irányú szignifikáns kapcsolatot a migrációtól várt bérkülönbségek és az elvándorlás megvalósulása között.

Az objektív anyagi viszonyokon túl az elméleti irodalom a szubjektív jólétérzet fontosságára is kitért. A különböző életkörülményekkel - például anyagi helyzettel vagy munkával - való elégedettség migrációt befolyásoló szerepét többen is igazolták. Ugyan nem a simoni elégedettségkoncepciót használva, de azzal rokonítható módon tette meg ezt szociológiai megközelítésből, kárpát-medencei romák migrációs potenciálját lineáris regresszió segítségével vizsgálva Örkény (2003b), tényleges migrációról szóló erdélyi adatokon logit modellt futtatva Gödry \& Feleky (2013), illetve magyarországi elvándorlási szándékokat ugyancsak logit modellel tesztelve Gödri (2016). Több korábbi

\footnotetext{
${ }^{24}$ Megjegyzendő, hogy Zaicava \& Zimmerman (2008a) egyik almintájukon, a 2004 előtt csatlakozott tagállamok 2001-es adatain pozitív irányú kapcsolatot is mértek, amelyet - részleteket nem taglalva adózási megfontolásokkal és a visszatérési szándékok potenciális meglétével magyaráztak.
} 
szociológiai megalapozottságú, logisztikus regressziók segítségével végzett kutatását összegző müvében Sik (2018) is ezt erősítette meg, továbbá a már hivatkozott tanulmányukban Zaiceva \& Zimmermann (2008a) is azt találták hogy a fizetésükkel elégedett személyek ceteris paribus szignifikánsan kisebb hajlandóságot mutattak az elvándorlásra. Behaviorista alapokról indulva, egyesült államokbeli adatokat és regressziós modelleket használva használva pedig Bach \& Smith (1977) tényleges migráció, Speare (1974), illetve Landale \& Guest (1985) pedig a migrációs szándékok és a tényleges migráció kapcsán támasztották alá az elégedetlenség elvándorlást ösztönző természetét.

A munkalehetőségekre vonatkozó várakozások ugyancsak megerősítést nyertek az egyedi adatokat használó kutatásokban is. Geis, Uebelmesser, \& Werding (2013) hivatkozott tanulmányukban igazolták, hogy az elvándorlók ceteris paribus az alacsonyabb munkanélküliségi rátával rendelkező országokban törekednek, Speare (1971) és Drinkwater (2003) pedig ezen jelenség inverzére - a származási hely magas munkanélküliségének taszító hatására - talált empirikus bizonyítékot. DaVanzo (1978) amerikai adatok segítségével szintén vizsgálta a kibocsájtó terület munkanélkülisége és az elvándorlás közötti összefüggést, ám a szignifikáns kapcsolat létét csak a munkanélküliek esetén erősítette meg.

Utóbbi eredmény tovább vezet arra a tényre - amely egyébként is a mikroszintü vizsgálatok előnyének tekinthető - hogy a szelekciós tényezők vizsgálatának megértésekor az aktorok egyedi jellemzőire érdemes fókuszálni. Azt, hogy a foglalkoztatottak a munkanélkülieknél kevésbé hajlamosak az elvándorlásra, több tanulmány is igazolta. Speare (1971), DaVanzo (1978), Örkény (2003a; 2003b), Gödri (2016), Sik (2018) hivatkozott írásai mellett Sandell (1977) amerikai migrációs adatokon logit modellel, Burda, Härdle, Müller, \& Werwatz (1998) pedig németországi migrációs hajlandóságokat rögzítő adatbázis segítéségével, félparaméteres eljárásokkal, a behaviorista alapokról kiinduló Epstein \& Gang (2006) pedig magyarországi elvándorlási hajlandósági adatokon probit modellel erősítették meg empirikusan az erre vonatkozó elméleti várakozásokat.

A cél és származási hely közötti távolságot korábban a mobilitási költségek proxyjaként azonosítottuk. A távolság növekedésének szignifikáns negatív hatását a migráció megvalósulására Speare (1971) igazolta, Hunt \& Mueller (2004) pedig amerikai és kanadai adatokon logisztikus regressziók segítségével támasztotta alá ugyanezt a célterület-választás kapcsán. Előbbi azt is megmutatta, hogy a potenciális migráns által 
várt további költözési költségek nagysága ugyancsak befolyásolja a személy későbbi döntését. Deaton, Morgan, \& Anschel (1982) a lelki költségek szerepét vizsgálták a migrációs hajlandósághoz elegendő bérkülönbség mértéke segítségével. Az Egyesült Államokbeli belső migrációra fókuszáló empirikus elemzésük azt erősítette meg, hogy a lelki költségek jelentősége szignifikáns lehet a vándorlási döntések meghozatalakor.

A migrációs hálózatok szerepének tesztelésére ugyancsak alkalmasabbak a mikroadatokat használó vizsgálatok, hiszen ezek arra tudnak kontrollálni, hogy az adott egyén ténylegesen rendelkezik-e a célterületen olyan kapcsolatokkal (például családtagok, barátok), amelyek megkönnyíthtetik számára az elvándorlást és a beilleszkedést. Ezen hálózati hatásnak a pozitív szerepét Speare (1971), Burda, Härdle, Müller, \& Werwatz (1998), Epstein \& Gang (2006), Zaiceva \& Zimmermann (2008a), valamint Geis, Uebelmesser, \& Werding (2013), Gödri (2016), Sik (2018) hivatkozott tanulmányai igazolják. Ugyanezt a pozitív irányú kapcsolatot erősítette meg behaviorista elméleti alapokról indulva, fülöp-szigeteki elvándorlási szándékok és tényleges viselkedési mikroadatokon logit modelleket futtatva De Jong, Root, Gardner, Fawcett, \& Abad (1986), illetve Ausztriába irányuló migrációs és ingázási hajlandóságokat multinominális probit segítségével vizsgálva Huber \& Nowotny (2013) is.

Szintén a hálózati hatás proxyjának tekinthető az, ha az egyén már rendelkezik korábbi migrációs tapasztalattal. Ennek pozitív szelekciós szerepét a későbbi migrációs szándékra vagy a tényleges elvándorlásra DaVanzo (1978), De Jong, Root, Gardner, Fawcett, \& Abad (1986), Drinkwater (2003), Fouarge \& Ester (2008), Zaiceva \& Zimmermann (2008a), Huber \& Nowotny (2013) továbbá Gödri (2016) hivatkozott tanulmányai igazolják. Ezt az összefüggést magyar mintán is több szerző alátámasztotta. Huzdik, Schwang, \& Takács (2010) kereszttáblás elemzéssel a külföldi munkábaállásról való vélekedés, Hárs \& Simon (2016a) logit modell segítségével az orvosmigráció kapcsán, Blaskó \& Gödri (2014) pedig multinomiális logit modell segítségével mutatta meg, hogy a nem Magyarországon születettek a többi magyar állampolgárnál ceteris paribus szignifikánsan nagyobb valószínűséggel döntenek az elvándorlás mellett.

A humántőke-elmélet következtetéseinek empirikus tesztelésére szintén a mikroadatok a megfelelőek. Azt, hogy a kor elörehaladtával általában csökken a kivándorlás valószínűsége - mivel az az időhorizont is rövidebb, amelyen a migráció várható hasznai jelentkeznek - számos vizsgálat bizonyítja. Ezek között említhetők Speare (1971), Bach \& Smith (1977), Sandell (1977), Landale \& Guest (1985), Burda, Härdle, Müller, \& Werwatz (1998), Drinkwater (2003), Örkény (2003a; 2003b), Hunt \& 
Mueller (2004), Epstein \& Gang (2006), Fouarge \& Ester (2008), Zaiceva \& Zimmermann (2008a), Huzdik, Schwang, \& Takács (2010), Gödri \& Feleky (2013), Huber \& Nowotny (2013), Gödri (2016), illetve Sik (2018) munkái. Ide sorolható továbbá Huzdik (2014), valamint Sik \& Szeitl (2016a) elemzései, amelyek rendre OLS, illetve logit modellel vizsgálták a magyarországi migrációs potenciált alakító faktorokat. Blaskó \& Gödri (2014), valamint Hárs \& Simon (2016a; 2016b) pedig korábban hivatkozott tanulmánya mellett más munkájukban szintén logit modellel a magyar munkaerőelvándorlás kapcsán fordított U-alakú kapcsolatot találtak a kor és a migrációs viselkedés között.

A humántőke minősége ugyancsak befolyásolja azt, hogy az egyén milyen eséllyel talál munkát egy másik országban. Azt, hogy a képzettségi szint emelkedésével ceteris paribus az elvándorlás valószínűsége is nő, már az általános humántőke-elmélet úttörője Mincer (1978) is megmutatta, aki a haszonmaximalizáló család képét használva többváltozós regressziókkal vizsgálta az amerikai családok kivándorlását befolyásoló tényezőket. Az elmélet implikációjára emellett Speare (1971), Sandell (1977), Burda, Härdle, Müller, \& Werwatz (1998), Drinkwater (2003), Hunt \& Mueller (2004), Epstein \& Gang (2006), Fouarge \& Ester (2008), Zaiceva \& Zimmermann (2008a), Huzdik, Schwang, \& Takács (2010), Huber \& Nowotny (2013), Blaskó \& Gödri (2014), Gödri (2016), Hárs \& Simon (2016b), illetve Sik (2018) tanulmányai nyújtanak empirikus bizonyítékot. Fordított irányú kapcsolatot, tehát negatív szelekcióra utaló jeleket csak Gödri \& Feleky (2013) talált a speciális, erdélyi mintájuk vizsgálatakor.

A nyelvtudás, különösen külföldre vándorlás esetén, szintén fontos jellemzője az egyén humántőkéjének. Azt, hogy a jobb idegennyelvtudással rendelkezők hajlamosabbak az elvándorlásra, Fouarge \& Ester (2008); Huber \& Nowotny (2013), Huzdik (2014), Gödri (2016) és Sik (2018) vizsgálatai támasztják alá.

A fentieken túl az empirikus vizsgálatok rendre kontrollálnak további demográfiai tényezőkre, amelyek szintén befolyásolják az egyén elvándorlási hajlandóságát. Ezek szerepét a szociológiai ihletésű irodalmak többnyire az egyén társadalmi szerepével vagy beágyazottságával hozzák összefüggésbe, a közgazdaságtudomány azonban - motivációt adva ezzel jelen disszertációnak is - nem szolgál egységes elméleti kerettel e faktorok kapcsán.

Az empíria azt mutatja, hogy az egyén neme alapvetően befolyásolja az elvándorlás valószínűségét. Noha Ravenstein (1885) XIX. század végén még azt találta, hogy a nők hajlamosabban a migrációra, az elmúlt évtizedek vizsgálatai, így Bach \& 
Smith (1977), Burda, Härdle, Müller, \& Werwatz (1998), Drinkwater (2003), Örkény (2003a, 2003b), Epstein \& Gang (2006), Fouarge \& Ester (2008), Zaiceva \& Zimmermann (2008a), Huzdik, Schwang, \& Takács (2010), Huber \& Nowotny (2013), Blaskó \& Gödri (2014), Huzdik (2014), Hárs \& Simon (2016b), Sik \& Szeitl (2016a), illetve Sik (2018) munkái kivétel nélkül azt mutatják, hogy ez a férfiakról mondható el. Sik \& Örkény (2003) szerint ennek okai föként a férfiak hagyományos társadalmi és családfenntartó szerepében, valamint kalandkeresőbb attitüdjében keresendők.

$\mathrm{Az}$, hogy valaki párkapcsolatban, de különösen annak intézményesített változatában, házasságban él, az empirikus vizsgálatok szerint szintén nagymértékben befolyásolja a migrációs hajlandóságot. De Jong, Root, Gardner, Fawcett, \& Abad (1986), Burda, Härdle, Müller, \& Werwatz (1998), Drinkwater (2003), Epstein \& Gang (2006), Fouarge \& Ester (2008), Zaiceva \& Zimmermann (2008a), csak Huzdik, Schwang, \& Takács (2010), Gödri \& Feleky (2013), Huber \& Nowotny (2013), Blaskó \& Gödri (2014), Huzdik (2014) és Gödri (2016) elemzései mind azt mutatják, hogy az egyedülállók nagyobb valószínűséggel döntenek az elvándorlás mellett.

A családi vonatkozású tényezök közül az is befolyásoló tényezö, hogy az egyénnek van-e gyermeke. Bach \& Smith (1977), Sandell (1977), Mincer (1978), Fouarge \& Ester (2008), Zaiceva \& Zimmermann (2008a), illetve Huber \& Nowotny (2013) eredményei azt erősítik meg, hogy a gyermekesek a gyermekteleneknél ceteris paribus nagyobb hajlandóságot mutatnak az elvándorlásra. A családméret meghatározó szerepét a korábbi irodalmak az együtt történő vándorlás esetén többnyire a növekvő költségekkel (Huber \& Nowotny, 2013; Mincer, 1978), a család otthonmaradása esetén pedig a lelki tényezőkkel (Zaiceva \& Zimmermann, 2008a) hozzák összefüggésbe. Ezzel ellentétes eredményre csak Huzdik, Schwang, \& Takács (2010) jutott, ők azonban ehhez egyszerű arányszámokat kalkuláltak, s így nem tudtak egyéb tényezőkre kontrollálni. Ezáltal módszerük korlátozottsága miatt következtetésük általánosíthatósága is erősen megkérődjelezhető.

Az empirikus vizsgálatokból az is kirajzolódik, hogy az ingatlantulajdonosok kisebb mobilitási hajlandóságot mutatnak, mint azok, akik nem rendelkeznek saját ingatlannak. Speare (1971), Bach \& Smith (1977), Burda, Härdle, Müller, \& Werwatz (1998), Fouarge \& Ester (2008) továbbá Zaiceva \& Zimmermann (2008a) tanulmányai rendre megerősítik az ingatlanok ilyen jellegü visszatartó erejét. Emellett Burda, Härdle, Müller, \& Werwatz (1998), illetve Zaiceva \& Zimmermann (2008a) eredményeiből azt a következtetést is levonhatjuk, hogy a nagyvárosok lakói szintén mobilisebbek a kisebb 
települések rezidenseinél. Előbbit Zaiceva \& Zimmerman (2008a) az ingatlaneladás extra költségeivel magyarázza, utóbbi okát pedig Örkény \& Sik (2003, 190. o.) annak tulajdonítja, hogy „a nagyvárosok részei a világvárosok közötti globális munkaerő-piaci, kommunikációs és kulturális kapcsolatok rendszerének".

Összességében tehát az látható, hogy a mikroszintű vizsgálatok nélkülözhetetlen adalékokkal szolgálnak az aggregált adatokkal dologozó kutatások mellé a nemzetközi migrációs folyamatok megértésében. Amellett, hogy képet adnak arról, hogy milyen attribútumokkal rendelkező személyek hajlamosabbak a migrációra, magának az elvándorlási döntésnek a természetéről, annak befolyásoló tényezőiről is információval szolgálnak. Mindezek összefoglalását a 1.3. táblázat tartalmazza. 


\section{3. táblázat}

\section{Az 1.2.1. alfejezetben feldolgozott mikroszintü irodalmak empirikus eredményeinek áttekintése}

\begin{tabular}{|c|c|c|c|}
\hline Forrás & Elméleti alap & Módszer & Minta \\
\hline Bach \& Smith (1977) & behaviorista & többváltozós regresszió & Egyesült Államok \\
\hline Blaskó \& Gödri (2014) & humántőke elmélet & logit & Magyarország \\
\hline Burda, Härdle, Müller \& Werwatz (1998) & vegyes & GPLM és logit & Németország \\
\hline DaVanzo (1978) & haszonmaximalizáló család & többváltozós regresszió & Egyesült Államok \\
\hline De Jong, Root, Gardner, Fawcett \& Abad (1986) & behaviorista & logit & Fülöp-szigetek \\
\hline Drinkwater (2003) & humántőke elmélet & rendezett probit & Kelet-Közpép-Európa \\
\hline Epstein \& Gang (2006) & behaviorista & probit & Magyarország \\
\hline Fouarge \& Ester (2008) & humántőke elmélet & logit & Európai Unió \\
\hline Geis, Uebelmesser \&Werding (2013) & humántőke elmélet & feltételes és multinomiális logit & 4 fejlett ország \\
\hline Gödri \& Feleky (2013) & vegyes & logit & Erdély \\
\hline Gödri (2016) & vegyes & $\operatorname{logit}$ & Magyarország \\
\hline Hárs \& Simon (2016a) & vegyes & $\operatorname{logit}$ & Magyarország \\
\hline Hárs \& Simon (2016b) & - & $\operatorname{logit}$ & Magyarország \\
\hline Huber \& Nowotny (2013) & véletlen hasznossági modell & multinomiális probit & Ausztria \\
\hline Hunt \& Mueller (2004) & humántőke elmélet & logit & Egyesült Államok, Kanada \\
\hline Huzdik (2014) & vegyes & többváltozós regresszió & Magyarország \\
\hline Huzdik, Schwang \& Takács (2010) & - & kereszttábla- és faktor analízis & Magyarország \\
\hline Landale \& Guest (1985) & behaviorista & logit & Egyesült Államok \\
\hline Mincer (1978) & haszonmaximalizáló család & többváltozós regresszió & Egyesült Államok \\
\hline Örkény (2003a) & - & többváltozós regresszió & Kárpát-medence \\
\hline Örkény (2003b) & szociológiai & logit & Kárpát-medence \\
\hline Sandell (1977) & haszonmaximalizáló család & logit & Egyesült Államok \\
\hline Sik \& Szeitl (2016a) & - & $\operatorname{logit}$ & Magyarország \\
\hline Sik (2018) & szociológiai & $\operatorname{logit}$ & Magyarország \\
\hline Speare (1971) & humántőke elmélet & többváltozós regresszió, diszkriminancia- és varianciaanalízis & Taiwan \\
\hline Speare (1974) & behaviorista & többváltozós regresszió & Egyesült Államok \\
\hline Zaiceva \& Zimmermann (2008) & humántöke elmélet & logit & Európai Unió \\
\hline
\end{tabular}


1.3. táblázat (folyt.)

\begin{tabular}{|c|c|c|c|c|c|c|c|c|c|c|c|c|c|c|c|c|c|c|c|c|}
\hline Forrás & Függő változó & $I_{j}$ & $I_{i}$ & $\Delta I$ & $U_{j}$ & $U_{i}$ & $D$ & Net & Age & $E d$ & $L$ & $E m p$ & $M$ & $C h$ & $M E$ & $M a$ & $C_{m}$ & $\mathrm{HO}$ & $C i$ & Sat \\
\hline Bach \& Smith (1977) & tényleges migráció & & & & & & & & - & & & & & - & & + & & - & & - \\
\hline Blaskó \& Gödri (2014) & tényleges migráció & & & & & & & & $\cap$ & + & & & - & & + & + & & & & \\
\hline Burda és mtsai. (1998) & migrációs szándék & & & & & & & + & - & + & & - & - & & & + & & - & + & \\
\hline DaVanzo (1978) & tényleges migráció & & & & & + & & & & & & - & & & + & & & & & \\
\hline De Jong és mtsai. (1986) & migr. szándék és tényleges migr. & & & & & & & + & & & & & & - & & + & & & & \\
\hline Drinkwater (2003) & migrációs szándék & & - & & & + & & & - & + & & & & - & & + & + & & & \\
\hline Epstein \& Gang (2006) & migrációs szándék & & & & & & & + & - & + & & - & - & - & + & + & & & + & \\
\hline Fouarge \& Ester (2008) & migrációs szándék & & - & & & & & & - & + & + & & - & - & + & + & & - & & \\
\hline Geis és mtsai. (2013) & célország-választás & + & & & - & & & + & & & & & & & & & & & & \\
\hline Gödri \& Feleky (2013) & tényleges migráció & & & & & & & & - & - & & & - & & & & & & & - \\
\hline Gödri (2016) & migrációs szándék & & & & & & & + & - & + & + & - & - & - & + & & & & + & - \\
\hline Hárs \& Simon (2016a) & tényleges migráció & & & & & & & & $\cap$ & & & & & & + & & & & & \\
\hline Hárs \& Simon (2016b) & tényleges migráció & & & & & & & & $\cap$ & + & & & & & & + & & & & \\
\hline Huber \& Nowotny (2013) & migrációs és ingázási szándék & & & & & & & + & - & + & + & & - & - & + & + & & & & \\
\hline Hunt \& Mueller (2004) & tényleges migr., célország-választás & & & & & & - & & - & + & & & & & & & & & & \\
\hline Huzdik (2014) & migrációs potenciál index & & & & & & & & - & & + & & - & & & + & & & & \\
\hline Huzdik és mtsai. (2010) & migrációs szándék & & & & & & & & - & + & & & - & + & + & + & & & & \\
\hline Landale \& Guest (1985) & migr. szándék és tényleges migr. & & & & & & & & - & & & & & & & & & - & & - \\
\hline Mincer (1978) & tényleges migráció & & & & & & & & & + & & & & - & & & & & & \\
\hline Örkény (2003a) & migrációs szándék & & - & & & & & & - & & & - & & & & + & & & & \\
\hline Örkény (2003b) & migrációs szándék & & & & & & & & - & & & - & & & & + & & & & - \\
\hline Sandell (1977) & tényleges migráció & & & & & & & & - & + & & - & & - & & & & & & \\
\hline Sik \& Szeitl (2016a) & migrációs szándék & & & & & & & & - & & & & & & & + & & - &,+- & \\
\hline Sik (2018) & migrációs szándék & & & & & & & + & - & + & + & - & & & & + & & &,+- & - \\
\hline Speare (1971) & tényleges migráció & & & + & & + & - & + & - & + & & - & & & & & - & - & & \\
\hline Speare (1974) & migr. szándék és tényleges migr. & & & & & & & & & & & & & & & & & & & - \\
\hline Zaiceva \& Zimmermann (2008) & migrációs szándék & &,-+ & & & & & & - & + & & & - & - & + & + & & - & + & - \\
\hline
\end{tabular}

Jelmagyarázat: $I_{j}$ : bérszínvonal (célország); $I_{i}$ : bérszínvonal (küldő ország); $\Delta I$ : relatív bérszínvonal; $U_{j}$ : munkanélküliség (célország); $U_{i}$ : munkanélküliség (küldő ország); $D$ : távolság; Net: hálózat; Age: kor; $E d$ : képzettség; $L$ : nyelvtudás; $E m p$ : foglalkoztatott; $M$ : házas; Ch: gyermekszám; $M E:$ migrációs tapasztalat; $H O$ : ingatlantulajdonos; $C i$ : nagyvárosi; Sat: elégedettség

Forrás: a táblázatban hivatkozott irodalmak 


\subsection{Az áttekintett irodalom értékelése}

Az áttekintett irodalom alapján az a kép rajzolódik ki, hogy noha a közgazdaságtudománynak érdemi elméleti és empirikus eredményei vannak a migrációt befolyásoló tényezők terén, ezek koránt sem mondhatók sem egységesnek, sem teljesnek. A közgazdaság-tudományban meglévő megközelítésmódok, iskoláknak - így a neoklasszikus mikro- és makroökonómia mellett a különböző heterodox irányzatok csírái - a migrációra vonatkozó leképeződései rendre megjelentek. Ezek azonban - noha gyakran hasonló megállapításokra jutnak - a különböző kiindulópontok és szemléletmódbeli különbségek miatt nem kompatibilisek egymással (lásd például a módszertani individualista mikroelmélet és a családi döntéshozatal feltevésére épülő MÚK viszonyát), illetve a megfelelő adatok hiányában többnyire nem tesztelhetők együtt empirikusan (lásd például a bérek szerepének befolyásoló erejének vizsgálatát a humántőke-elméletet egyedi adatokon tesztelő kutatásokban).

Ezen túlmenően maga a - közgazdaság-tudomány fóáramát leginkább reprezentáló - humántőke elmélet sem képes teljes képet adni a migrációs döntést befolyásoló tényezőkről, s ezáltal a vándorlások mozgatórugóiról sem. Noha az kétségkívül fontos és értekelendő, hogy a migráció kutatói a közgazdaság-tudomány fejlödésével párhuzamosan igyekeztek az újabb irányzatok vívmányait beépíteni modelljeikbe, de ez - főként az utóbbi évtizedekben jelentős fejlődést mutató intézményi és viselkedési kögazdaságtani iskolák tekintetében - csak az új ismeretanyagok töredékére vonatkozott, s gyakran ezek az újonnan kidolgozott modellek sem használtak egységes nyelvezetet. Ezáltal azonban az egységes keretbe illesztésük sem lehetséges.

Hasonló megállapítás tehető az empirikus vizsgálatok több eredményével (például gyermekesek, ingatlantulajdonosok mobilitása) kapcsolatban is. Ezek szignifikáns szerepe a migrációs döntésben empirikus alapon megkérdőjelezhetetlen, sőt a szociológiai elméletekbe is jól beágyazottak, a közgazdaság-tudomány azonban - egyegy önálló kísérleten és a hétköznapi nyelven egyébként logikus magyarázatokon túl nem kínált egységes keretbe illeszthető magyarázatot a szerepükre. A szociológia és más határterületek elméleti konstrukcióiról, illetve empirikus felismeréseiről ugyancsak ez mondható el.

A migráció közgazdasági elméleteiről tehát vegyes megállapítások tehetők. Egyrészt elvitathatatlan, hogy mély és előremutató konstrukciókkal rendelkezik a vándorlási folyamatok okainak és mozgatórugóinak magyarázatában, azonban továbbra 
is hiány mutatkozik néhány újabb irányzat vívmányainak felhasználásában, s mindennek az egységes gondolkodási keretbe történő helyezésében. Mindezek tükrében azt látjuk, hogy jelentős tér mutatkozik arra, hogy az utóbbi évtizedekben rohamosan fejlődő intézményi és a viselkedési közgazdaságtan vívmányait alkalmazzuk a migrációra. Ezzel egyrészt előrelépés érhető el, s új tényezők emelhetők be a migrációs döntést magyarázó modellbe, másérszről korábban szeparáltan, más-más iskolák felismeréseiben meglévő tudás integrálható egységes keretbe.

Az empirikus irodalom értékelése kapcsán ugyancsak hasonló értékelés fogalmazható meg. Egyrészt elmondható, hogy az empirikus vizsgálatok a főbb elméleti predikciókat rendre igazolni tudták, másrészt azonban - mint azt fentebb jeleztük - olyan eredményekre is jutottak, amelyekről az elméletek nem, vagy csak elvétve szóltak. Noha igaz, hogy a témában tesztelt ökonometriai modellek rendre alacsony magyarázóerővel bírtak, ez inkább az alkalmazott módszerek valódi empírián történő alkalmazásának sajátosságának tekinthető. Mindazonáltal az, ha a meglévő modellek magyarázó-erejét további - mind elméleti szempontból plauzibilisen igazolható, mind az empirikus munkában szignifikánsnak mutatkozó - változók bevonásával javítani tudjuk, az előrelépésként értékelhető. Annál is inkább, mivel a globális és az Európai Unión belüli migrációs mintázat kapcsán a legfőbb empirikus puzzle-t továbbra is a helyben maradás rejtvénye adja: az alacsony mobilitási költségekkel bíró környezetben miért nem választják a migrációt azon tömegek, akiknek ez a meglévő közgazdasági modelljeink alapján úgy tünik, hogy racionális lenne? Álláspontunk szerint az eddig a migrációs irodalomban kiaknázatlan intézményi közgazdaságtani megközelítés tud további adalékokkal szolgálni ehhez a kérdéshez, ami ugyancsak érdemi előrelépésnek tekinthető. 


\section{ELMÉLETI MODELL}

Disszertációnk fókuszában a migráció, illetve elvándorlás jelensége áll, amely fogalmak alatt - a bevezetésben rögzítetteknek megfelelően - az országhatáron túlra irányuló, tartós, jellemzően munkavégzési és/vagy letelepedési céllal történő önkéntes költözést értjük. ${ }^{25} \mathrm{~A}$ módszertani individualista logika alapján a migrációt egyéni cselekvésnek tekintjük. Ebben az értelemben disszertációnk elméleti modellje a Sjaastadféle (1962) megközelítésmódon alapszik, amely az elvándorlást az egyén preferenciái alapján meghozott döntésként kezeli, de számos ponton módosít rajta.

Mindezt a következő szerkezetben vázoljuk fel. Először a modell aktorára vonatkozó viselkedési előfeltevéseket fektetjük le, amit az aktor és az őt körülvevő intézményi környezet kapcsolatának bemutatása követ. Ezután a migrációs döntés folyamatát, illetve annak kimenetelét befolyásoló tényezőket részletezzük, majd a fejezetet a modell formális felírásával és összegzésével zárjuk.

\subsection{Viselkedési előfeltevések}

Modellünk döntéshozó szereplöje az egyén, aki a migrációs döntés meghozatalakor a helyben maradás, illetve a külföldre költözés alternatívái közül választ. A neoklasszikus közgazdaságtani megközelítésekkel, a várható haszon elméletével, valamint az előző fejezetben áttekintett modellek nagy részével szemben azonban jelen disszertációban az egyénről nem tételezünk fel tökéletes racionalitást. Utóbbi az objektívan leírhatónak mondott valóságra vonatkozó teljes informáltságot, a jól viselkedő preferenciák létét és a tökéletes kalkuláción alapuló haszonmaximalizálást kívánná meg az aktortól (Machina, 1987). Tekintve azonban, hogy az empíria oldaláról ezen feltevéseknek gyakorlatilag mindegyike megkérdőjelezhető, a továbbiakban az intézményi közgazdaságtan hagyományainak (Williamson, 2000) megfelelően egy korlátozottan racionális emberképpel fogunk dolgozni.

A korlátozott racionalitás fogalma - mint azt már az irodalmi áttekintésben említettük - Simon $(1959 ; 1972)$ nevéhez füződik, de a fogalom értelmezése nem egységes az irodalomban, még a különböző intézményi szerzők - így North (2010) és Williamson (1985) is - különböző jelentéstartalommal használják modelljeikben. Simon (1987) kiindulópontja az, hogy az emberi agy kognitív korlátokkal rendelkezik: a világot

\footnotetext{
${ }^{25}$ Ez a meghatározás - bizonyos adatfelvételi szempontok szerint - még tovább pontosítható. Az ezzel kapcsolatos dilemmákat a 3.1. alfejezetben tárgyaljuk részletesen. Mindazonáltal elméleti modellünk megalkotásához a fenti definíció tartalmazza az elégséges feltételeket.
} 
a maga teljességében nem vagyunk képesek felfogni, nem birtoklunk minden, a döntéseink meghozásához szükséges információt, s még ha így is lenne, akkor sem lennénk képesek ezekkel bonyolult matematikai, optimalizációs eljárások lefolytatására. Ezért az emberi viselkedés szándéka szerint lehet ugyan racionális, de megvalósulását tekintve csak korlátozottan az (Simon, 1997). Simon szerint emiatt az egyén nem a hasznosság maximalizálására, csak a megelégedésre törekszik. Egy aspirációs szintet állít maga elé, amelyet el szeretne érni. Ezt követően pedig - az általa addig ismeretlen alternatívák között - keresésbe kezd, amelyet addig folytat, míg egy, az aspirációihoz mérten, kielégítő alternatívát talál. Ezt a folyamatot Simon (2008) a 'satisficing' kifejezéssel írja le. Keresésében, s az azt magába foglaló döntési folyamatban pedig különböző heurisztikák, hüvelykujj-szabályok segíthetik, ,amelyek hozzájárulnak a kognitív erőfeszítések csökkentéséhez azáltal, hogy egyszerü, az elme számára könnyen hozzáférhető döntési megoldásokat kínálnak" (Tóth , 2018, 8. o.).

A Williamson (1985) által kidolgozott tranzakciós költségek elmélete - amely jelen disszertáció elméleti modelljének egyik alappillére - ennél szükebb értelemben használja a korlátozott racionalitás fogalmát. Modelljének viselkedési előfeltételi között Williamson leszögezi, hogy az általa felvázolt ember - a contractual man - korlátozottan racionális: szándékai (ti. a racionális kalkuláción alapuló hasznosságmaximalizálás) megegyeznek ugyan a homo oeconomicus-éval, kognitív képességei azonban korlátosak. Ennek Wiliamsonnál az az egyenes következménye, hogy az egyén nem tud teljeskörü szerződést kötni, így nagy mértékü kitettségbe kerül a partner opportunizmusával szemben, amelyre a tranzakciók különböző irányítási struktúrái ${ }^{26}$ szolgálhatnak válaszul. Mindazonáltal a korlátozott racionalitásnak a döntéshozatali mechanizmusra vonatkozó implikációit Williamson szándékosan nem veszi be a modelljébe, mivel figyelme elsősorban a tranzakciók lebonyolítási módjaira, illetve azok gazdasági implikációira irányul. Így a korlátozott racionalitás fogalma alatt csak a világ és a jövő nem teljes körü ismeretét érti. A maximalizálás mint a legjobb alternatíva választásának szándéka ezáltal a tranzakciós költségek elméletében is megmarad, azzal a megkötéssel, hogy a korlátozott kognitív képességekkel rendelkező aktor által észlelt legjobb variáns nem feltétlenül egyezik meg az objektíve tekintett legjobbal.

Mivel az alternatívák felkutatása a Williamson-féle gondolkodási keretnek nem képezi részét, ezért a tranzakciós költségek elmélete annak módjára nem is tér ki.

\footnotetext{
${ }^{26}$ Irányítási struktúra Williamson $(2007,238$. o.) elméletében az „az intézményi keret, amelyen belül a tranzakciót megkötik és végrehajtják".
} 
Tekintve azonban, hogy a migrációs döntés kapcsán ez kulcsfontosságú szempont, jelen disszertáció viselkedési előfeltevéseinek lefektetésekor nem hagyhatjuk figyelmen kívül. Ehhez egy másik Nobel-emlékdíjas intézményi közgazdász, North (2010) megközelítésmódja nyújt segítséget. North az intézmények funkciója kapcsán tárgyalja a korlátozott racionalitás fogalmát, amely alatt a külső környezet komplexitására, illetve annak ismeretére vonatkozó hiányosságokat ért. Érvelése szerint a racionalitás tökéletlensége miatt az egyén bizonytalansággal szembesül, amelyben az intézmények jelentenek számára segítséget. Az intézmények stabilitást adnak a társadalmi rendszerben, mivel megkönnyítik a szereplök döntéshozatalát. ${ }^{27}$ Egyszersmind strukturálják az emberek interakcióit is, szabályozott mintát adnak nekik, s ezáltal a döntéshozatal mechanizmusát is megkönnyítik - például az adott helyzet felfogásának értelmezésével vagy a lehetséges alternatívák számának csökkentésével, ami ugyancsak segítséget jelent a korlátozott kognitív képességekkel rendelkező egyén számára. Az intézményeken túl - mint azt később tárgyaljuk - North (2010) a tranzakciós költségek ${ }^{28}$ létét is a racionalitás tökéletlenségéböl, s a döntéshez szükséges információ megszerzésének költségességéből vezette le. Összességében tehát azt látjuk, hogy Northnál a korlátozott racionalitás koncepciója egyfajta „eszközként” jelenik meg az általa középpontba helyezett elméleti konstrukciók bevezetésének indoklására. Tartalmában ő is szükebben használja a fogalmat, mint Simon: főként az egyén hiányos informáltságára utal vele. A racionalitás korlátozottsága nyomán azonban hangsúlyozza, hogy az egyén mind a keresésben, mind a döntéshozatalban gyakran jár el heurisztikák alapján, s ebben is az intézmények vannak a segítségére. ${ }^{29}$

Utóbbi gondolatát szerzőtársával közösen írt tanulmányában fejtik ki részletesen (Denzau \& North, 1994). Itt is abból indulnak ki, hogy bizonytalansággal szembesülve az egyén - kognitív korlátai és a világ komplexitása miatt - nem képes a tökéletesen racionális döntésre. Mint írják, ilyenkor ,az emberek részben mítoszok, dogmák, ideológiák és »sületlen« elméletek alapján cselekednek" (Denzau \& North, 1994, 3. o.). Ez azt jelenti, hogy a bizonytalanság kezelésére valamilyen mentális modellt hívnak segítségül, amely megkönnyíti a döntést. A mentális modellek egyfajta belső

\footnotetext{
${ }^{27}$ Az intézmények alatt szabályokat értünk. Mindennek részletes kifejtésére, valamint az intézmények jelen disszertáció modelljében való szerepének bemutatására a 2.2. alfejezetben kerül sor.

${ }^{28}$ Tranzakciós költségek alatt itt az egyes tranzakciók lebonyolításának járulékos terheit értjük. Részletes tárgyalásukra a 2.3. alfejezetben kerül sor.

${ }^{29}$ Hangsúlyozandó ugyanakkor, hogy a simoni megelégedésre törekvésen alapuló döntési mechanizmust North (2010) nem teszi magáévá Ékes példája ennek az, hogy az intézmények változását is az egyének haszonmaximalizáló törekvéseinek tudja be.
} 
gondolkodási rendszerként értelmezhetők, amelyek bizonyos séma szerint segítenek interpretálni a külső környezet. Ezek mindig egy tanulási folyamat eredményei, amelyek az egyén tapasztalásai során folyamatosan épülnek. Ugyanakkor hangsúlyozzák, hogy az azonos közösségen belüli személyeknek, illetve akik közös kulturális háttérrel rendelkeznek, a tanulási folyamatai és tapasztalatai is hasonlóak lesznek, ezáltal a mentális modelljeik is konvergálnak majd. Álláspontjuk szerint ennek köszönhető, hogy az ilyen, közös mentális modellel rendelkező személyek hasonlóan interpretálják az előttük álló szituációkat, hasonlóan értékelik őket, s így döntésük eredménye is hasonló lesz.

Mindez a keresésre is implikációkat hordoz magában. Mint írják, „,a szubsztantív racionalitás által adott eredmények egyik alapvető problémája az, hogy a választások menüje a priori nem igazán ismert a döntéshozó számára. Magát ezt a menüt is meg kell ismerni (Denzau \& North, 1994, 21. o.)”. Ez a folyamat is az előbbi, közös mentális modellek által befolyásolt módon történhet.

Viselkedési előfeltevéseink megfogalmazásakor a fenti megközelítésekre alapozunk. Modellünk szereplőjéről korlátozott racionalitást tételezünk fel, amely Williamson (1985) értelmezésének megfelelően - az aktor rendelkezésére álló információk hiányosságára utal. Ez a migrációs döntés kapcsán indokoltnak tekinthető, hiszen Denzau \& North (1994) megállapítása, mely szerint a menü nem ismert, itt is áll: aligha képzelhető el, hogy valaki egy olyan horderejü döntést, mint az elvándorlás, teljes informáltság birtokában hozzon meg. Ez ugyanis azt jelentené, hogy az egyénnek a világ összes országára vonatkozóan ismernie kellene az aktuálisan és a jövőben elérhető (várható) hasznok és költségek mértékét. ${ }^{30}$ Ebből kifolyólag az egyén kezdetben csak korlátozott mennyiségü információval rendelkezik a külföldi lehetőségekről, olyanokkal, amelyeket költségmentesen - akár akaratán kívül - tudott beszerezni. Ilyenek lehetnek például a munkája révén szerzett vagy a médiumokból rárakodó ismeretek, a barátoktól, ismerösöktől hallott tapasztalatok, elbeszélések, de ide tartozhatnak a Denzau \& Northféle (1994), kulturális közösségből érkező közös ideák és vélekedések is. Amikor az egyénben megfogalmazódik az elvándorlás gondolata - amely szintén lehet a közös kulturális gondolkodási keret produktuma -, keresésbe, információgyüjtésbe kezd. Ez azonban költséges folyamat, tranzakciós költségekkel jár, amelyekről a 2.3. alfejezetben

\footnotetext{
${ }^{30}$ Felidézve Hayek (1945) gondolatait, ez még elméletben és egy szükebb körben sem lenne lehetséges, hiszen mire az egyén összegyüjtené és feldolgozná az aktuális viszonyokra vonatkozó tudást, az addigra könnyen lehet, hogy elavulttá válna.
} 
részletesen is szólunk majd. Fontos azonban kiemelni, hogy ezen keresés nem a Stiglerféle (1989) értelemben vett racionális maximalizációs folyamat. Nem feltételezzük tehát, hogy a potenciális migráns pontosan addig folytatja az információgyüjtést, amíg annak határhaszna egyenlő nem lesz annak határköltségével. Korlátozott racionalitása miatt ugyanis irreális lenne azt feltételezni, hogy utóbbi változókra vagy azok várható értékeire vonatkozó érdemi információkkal rendelkezne. Helyette heurisztikus keresésbe kezd: hüvelykujj-szabályok, hallomások, ajánlások, a társadalomban látott viselkedésminták, a közös mentális modellek alapján futtatja le keresési köreit, így az ezek révén könnyen elérhető információkat gyüjti be. Ennek során adott esetben akár az objektíve optimális alternatívára is rátalálhat, de alapvetően az mondható el, hogy többnyire olyan ismeretek kerülnek a birtokába, amilyenek a környezetében élőkhöz is eljutnak. Így információs bázisa, amelyen a döntését meghozza, hasonló lesz a vele kapcsolatban lévőkéhez, amelynek eredményeként döntése is korrelálhat az utóbbiakéval. Végül az aktor a megszerzett információk alapján, szándéka szerint racionálisan hozza meg döntését: az elötte álló alternatívák közül az általa legjobbnak ítéltet választja. Ez azonban - bár elméleti szinten előfordulhat - nem esik szükségszerüen egybe az objektíve optimálisnak mondható variánssal, sőt adott esetben még az is elöfordulhat, hogy a rendelkezésre álló választási lehetőségek közül sem a tényleges legjobb. Az ember kognitív korlátai, s a heurisztikus gondolkodásmódja miatt - ti. az, hogy a valóság szubjektív értelmezése is függ attól a társadalmi közegtől, amelyben a szereplő él (Denzau \& North, 1994; North, 2010) - ugyanis sem a rossz szubjektív észlelés, sem a tévedés nem zárható ki a modellben. Mindazonáltal ezek a tényezők nem mondanak ellent annak, hogy az egyén szándékai szerint a legjobb döntést szeretné hozni.

Mindezek kapcsán szót kell ejtenünk a „legjobb alternatíva” fogalmának értelmezéséről is. Ahogy az a közgazdaság-tudományban évszázados viszonylatban is alapvetésnek számít (Edgeworth, 1881), modellünk aktoráról önérdekkövetést feltételezünk. Ennek alapján a potenciális migráns szemszögéböl nézve az számít a legjobb alternatívának, amely - a személyenként eltérő, de adott időben adottnak tekintett preferenciái alapján - a legmagasabb hasznossági szintet biztosítja számára.

Ebben az önérdekkövető keretrendszerben azonban - pontosan az egyén preferenciáira vonatkozó feltevések megfogalmazásával - teret engedünk az altruizmus megjelenésének is. Altruizmus alatt általánosságban a mások iránti jóindulatot, a mások érdekeinek figyelembe vételét szokás érteni. A továbbiakban ennek az önző altruizmusnak nevezett változatát (Hámori, 1998) használjuk, amelyet az interdependens 
preferenciák (Pollak, 1976) segítségével vezetünk be a modellünkbe. Altruizmusként a továbbiakban egy olyan magatartásformát definiálunk, amelynek révén az egyén azonos előjellel internalizálja egy másik szereplő jólétét a saját hasznossági függvényébe (Rapoport, 1995). Ez a hatás azonban nem egyfajta externáliaként jelentkezik. Nem valamilyen cselekvésből, hanem az interperszonális kapcsolatokból fakad, s az emberek közötti viszonyrendszeren alapszik (Choi, 1993; Hámori, 1998). Effajta alkalmazással többek között Becker $(1974 ; 1976)$ munkáiban találkozhatunk, úgy, hogy az altruista egyén által maximalizálandó célfüggvénybe független változóként más gazdasági szereplők jóléte is beemelésre kerül.

Az altruista magatartásforma szerepeltetését modellünkbe az egyén korlátozott racionalitása indokolja. Amint ugyanis Simon (1990; 1993) kifejti, a folytonos költséghaszon kalkulációkra nem képes emberi agy - összhangban a heurisztikus döntéshozatal és Denzau \& North (1994) közös mentális modellekről szóló gondolataival - gyakran a társadalomban látott minták alapján hoz meg bizonyos döntéseket. A társadalom azonban, amelynek csoportszinten érdeke az altruizmus, ilyen, altruista magatartásra igyekszik tanítani az arra fogékony, Simon megfogalmazásában docilis egyéneket. Utóbbiak ezáltal - az altruizmus definíciójának megfelelően - akkor is figyelembe veszik döntéseikben mások érdekeit, ha azok esetleg szembemennek a sajátjaikkal.

Hangsúlyozandó ugyanakkor, hogy modellünkben nem azt állítjuk, hogy mindenki altruista lenne. Ezen attitüd megléte és mértéke személyenként, sőt még adott személy esetében az idő múlásával is változhat. Az interdependens preferenciák segítségével formalizált altruizmus modellbe emelésével ugyanakkor megnyitjuk annak a lehetőségét, hogy ezen intuitíve is létezőnek gondolt, s empirikusan is igazolt (Piliavin \& Charng, 1990) viselkedésforma jelentőségét vizsgáljuk a migrációs hajlandóságot befolyásoló tényezők között. ${ }^{31}$

Disszertációnk viselkedési feltevéseit összefoglalva tehát azt mondhatjuk, hogy modellünk szereplöje szándéka szerint racionális, de ténylegesen csak korlátozottan az.

\footnotetext{
${ }^{31}$ Megjegyzendő, hogy a modellünk kiindulópontjának tekintett, Williamson-féle tranzakciós költségek elméletében az altruista magatartás nem jelenik meg. Sőt, Williamson $(1985 ; 2007)$ munkáiban a szereplők egy részéröl jóindulat helyett az önérdekkövetés erős formáját, opportunizmust feltételez. Ezt egyfajta ravaszsággal is kiegészülö önérdekkövetésként definiálja, amely mind a formális, mind az erkölcsi szabályok szándékos áthágását is magába foglalhatja a nagyobb haszon reményében. Ennek a magatartásformának azonban elsősorban - így Williamsonnál is - a szerződéses kapcsolatok irányításánál van jelentősége, amely kívül esik jelen disszertáció vizsgálódási keretén. Így, noha elismerjük, hogy az opportunista attitüd akár a mi modellünk szereplöire is jellemző lehet, a migrációs döntéssel kapcsolatos relevanciájának hiányában a továbbiakban nem tárgyaljuk.
} 
Kognitív képességeinek korlátai miatt a valóságot a maga teljességében nem ismeri, ezért a lehetséges alternatívákat, s az azokra vonatkozó információkat fel kell kutatnia. Ezen információgyüjtés azonban nem optimalizáló, hanem heurisztikus kereséséi folyamat. Az ennek révén felkutatott lehetőségek közül végül azt a variánst választja, amely szubjektív értékelése szerint számára a legjobb, azaz a lehetséges alternatívák közül a legnagyobb hasznossági szintet biztosítja. Ezen legjobb alternatíva kiválasztásában az egyént az önérdeke vezéreli, de amennyiben a preferenciái interdependensek - amely lehetőséget megengedjük modellünkben - úgy altruista attitüdöket is mutathat.

\subsection{Intézmények és intézményi bizalom}

Migrációs döntését az egyén nem egyfajta „légüres térben” hozza meg. Döntése kimenetelét az intézmények is befolyásolják. Az intézmények North (2010, 13. o.) megfogalmazásában „a társadalom játékszabályai, vagy még formálisabban: az emberek közötti interakciót meghatározó, az emberek által kialakított korlátok." Az intézmény terminus így - a hétköznapi szóhasználattól eltérően - élesen elkülöníthető a szervezet fogalmától, hiszen előbbi a szabályra, utóbbi pedig az aszerint ,játszó” szervezeti struktúrával rendelkező ,játékosra” utal. Az intézmények szerepét és jellemzőit jelen fejezet további részében szintén North $(1991 ; 2010)$ alapján ${ }^{32}$ mutatjuk be. ${ }^{33}$

Az intézmények meghatározzák a gazdasági szereplők ösztönzőit: cselekvési szabályokat jelenítenek meg, bizonyos tevékenységeket jutalmaznak, másokat pedig büntetnek. Funkciójuk többek között az, hogy megkönnyítsék a tranzakciók lebonyolítását, valamint az egyéb társas érintkezéseket. A korlátozottan racionális egyénnek így nem kell minden interakció során bonyolult optimalizációt végeznie arra vonatkozóan, hogy milyen eljárás lenne a legkifizetődőbb számára, hisz a szabályok, normák leszűkítik a választási lehetőségeit és iránymutatást is nyújtanak a követendő magatartásformára vonatkozóan. A kooperáció irányába terelik az emberi cselekvéseket azáltal, hogy tiltanak bizonyos nem kívánatos magatartásformákat, s az elkövetésük esetén szankciókat helyeznek kilátásba. Mindezzel a bizonytalanságot csökkentik, hiszen elősegítik a jövő kiszámíthatóbbá tételét.

\footnotetext{
${ }^{32} \mathrm{Az}$ intézmények pontos meghatározásával kapcsolatban több versengő álláspont is létezik az intézményi közgazdaságtanon belül. Ezek egy jelentősebb szegletéről Hodgson (2006) ad jó áttekintést. Utóbbiból az is kirajzolódik, hogy az egyes kutatók a különböző definíciók ellenére meglehetősen hasonló jellemzőket és funkciókat társítanak az intézményekhez. Mindazonáltal, az itt lefektetett definíciós keret és a fogalmi következetesség megtartása érdekében ezen megközelítések bevonásától eltekintünk

${ }^{33}$ Jelen alfejezet bizonyos része, illetve az ezek tesztelésére vonatkozó eredmények szerkesztett változata megjelent: Golovics (2018).
} 
Az intézmények hatásossága kapcsán fontos szempontként jelenik meg a kikényszerítés erőssége. Az intézmények ugyanis rögzíthetnek bizonyos viselkedési előírásokat, s a szabálysértés esetén alkalmazandó szankciókra vonatkozó kitételeket is tartalmazhatnak, ezeket azonban valakinek - bizonyos személy(ek)nek vagy szervezeteknek - alkalmazniuk is kell. Az intézmények ugyanis csak akkor adnak valódi ösztönzőket a gazdasági szereplőknek, ha azokat ki is kényszerítik. A szabálysértés esetén történő szankcionálást nevezzük az intézmény betartatásának, érvényesítésének vagy kikényszerítésének. Ezzel összefüggésben két tényezőt kell kiemelnünk: a szabálysértés felderítésének költségességét, amely befolyásolja a lebukás valószínüségét, valamint a büntetés mértékét. Elmondható ugyanis, hogy az egyén, aki egy adott intézményi környezetben maximalizálja a hasznosságát, két alternatíva közül választhat: az adott szabályokat elfogadva, azok keretei között próbálja a legjobb megoldást választani vagy áthágja azokat, s egy tiltott opciót választ. ${ }^{34}$ Értelemszerüen akkor dönt az utóbbi mellett, ha az abból várható nettó haszon még akkor is nagyobb az egyéb opciókból származókénál, ha figyelembe veszi a lebukás esetén járó, annak valószínűségével diszkontált büntetés mértékét. Mindez azt mutatja, hogy a gazdasági szereplők viselkedése szempontjából alapvető fontosságú, hogy a rájuk vonatkozó intézményeket milyen mértékben tartatják be, s milyen büntetéssel sújtják a szabályszegőket.

Az intézményeknek két fajtáját különböztetjük meg: a formális és az informális intézményeket. Utóbbiak alatt olyan íratlan szabályokat értünk, amelyek ,,a hivatalosan szankcionált csatornákon kívül jönnek létre, azon kívül adják át és kényszerítik ki őket” (Helmke \& Levitsky, 2004, 725. o.). Ezek főként társadalmi normák, konvenciók, amelyeket a közösség kényszerít ki a tagjaitól. Ezzel szemben formális intézmények alatt a hivatalos csatornán született és kikényszerített, többnyire írásos szabályokat értjük. Egy szervezet esetén ilyen lehet egy belső működési szabályzat, ide sorolhatjuk a gazdasági szereplők által kötött szerződéseket, makroszempontból pedig a különböző jogszabályokat említhetjük. Utóbbiak esetén elmondható, hogy a kikényszerítésről az állam - a szintén hivatalos jogszabályban rögzített eljárásoknak megfelelően gondoskodik. A két típus mind kiegészítő, mind helyettesítő viszonyban lehet egymással,

\footnotetext{
${ }^{34}$ Az említett alternatívák mellett North (2010) egy ezektől eltérő stratégia lehetőségét is megfogalmazza: az egyén dönthet úgy, hogy erőforrásait a fennálló intézményeknek - például a lobbizás útján történő megváltoztatására fordítja. Ez azonban tovább vezet az intézményi változás, valamint a járadékvadászat témáihoz, amelyek kívül esnek jelen disszertáció fókuszán. Előbbiről North (2010), utóbbiról pedig többek között Tullock (2005) ad áttekintést.
} 
de általánosságban az mondható el, hogy a jól müködő társadalmi és gazdasági élethez mindkettőre szükség van. ${ }^{35}$

Az intézmények kapcsán fontos szempont azok változékonysága - vagy a másik oldalról nézve a stabilitása. Az informális intézményeket - mivel ezek gyakran a hagyományokra és a kultúrára alapozódnak, s be vannak ágyazódva a társadalom szöveteibe - a stabilitás jellemzi, mesterséges megváltoztatásuk pedig általában lassú és nehézkes folyamat. Ezzel szemben a formális intézményeket - a szabályalkotó akaratának függvényében - egyik napról a másikra meg lehet változtatni. Ennek pozitív és negatív implikációi is vannak. Noha az intézmények folyamatos változása elengedhetetlen a gazdasági szereplők, s maga a gazdasági fejlődés szempontjából, a túl gyors és hirtelen változások kiszámíthatatlanságot idézhetnek elő a rendszerben. Ilyen esetekben az intézmények sem a bizonytalanság- sem a tranzakciós költség-csökkentő szerepüket nem tudják betölteni, ráadásul abban is meggátolják a gazdasági szereplőket, hogy hosszú távra tervezzenek, ami a jövőbeni fejlődést áshatja alá.

A jó vagy jól müködő intézmények tehát érdemben meg tudják könnyíteni a gazdasági szereplők életét, míg a rosszak vagy rosszul működők jelentősen megnehezíthetik azt. A fentiekböl pedig a különbségtétel alapjai is kirajzolódnak. Egyrészt elmondható, hogy a jó intézmények támogatják a kooperációt és elősegítik a tranzakciók lefolyását többek között azzal, hogy mind a bizonytalanságot, mind a tranzakciós költségeket csökkentik. Másrészt fontos hangsúlyozni, hogy ezen funkciójukat csak akkor töltik be ténylegesen, ha a társadalom tagjai ismerik őket, sőt azt is tudják, hogy az intézményeket - akár a közösség, akár az állam, akár más szereplö be is tartatja. Az intézmények jó müködéséhez tehát egyik oldalról fontos a korábban már említett stabilitás, másik oldalról azonban - némiképp talán paradox, vagy éppen önbeteljesítő módon - az is elengedhetetlen, hogy az emberek elhiggyék róluk, hogy jól müködnek. Ezzel pedig az intézményi bizalom témájához érkezünk meg, amelyet az alábbiakban fogunk ismertetni.

Intézményi bizalom alatt az emberek abba vetett, tapasztalaton alapuló, bizonyosságát értjük, hogy „az intézménynek megvan a szándéka és a képessége is ahhoz, hogy a feladatát betöltse" (Győrffy, 2017, 34. o.). ${ }^{36}$ Ebben - mint az a fentiekben kirajzolódott - kiemelt szerepe van az államnak és az állami igazságszolgáltatásnak. Mint

\footnotetext{
${ }^{35}$ A két intézménytípus lehetséges viszonyulásairól Helmke \& Levitsky (2004) ad áttekintést.

${ }^{36}$ Az intézményi bizalom ebben az értelemben tehát jól elkülöníthető a személyek közötti (interperszonális) bizalomtól. Utóbbiról, valamint ezek összevetéséről szintén Győrffy (2017) ad áttekintést.
} 
azonban Győrffy (2017) mellett Hardin (1999) is kiemeli, az állammal szemben, amely rendelkezik az erőszak monopóliumának jogával, a természetes attitüd a bizalmatlanság lenne.

A bizalmatlanságot az változtathatja meg, ha az állam a jogállamiság keretein belül müködik, s nem él vissza a hatalmával. Az ilyen államokat az intézményi közgazdaságtan North, Wallis, \& Weingast (2009) munkája nyomán önkorlátozó államnak nevezi, amelyek nyílt hozzáférésü társadalmi rendet müködtetnek. A társadalmi státusztól független nyílt hozzáférés elsősorban az erőforrásokra és a szervezetekre vonatkozik, amelyet az intézmények (magántulajdon garantálása, szerződések kikényszerítése) révén az állam biztosít. A jogállamiság fontos feltételei közé tartozik az is, hogy mindezeket az állam saját magával szemben is garantálja polgárai számára. ${ }^{37}$

Ezen a gondolatmeneten tovább lépve Győrffy (2017) alapján megállapítható, hogy az intézmények esetén az adhatja a bizalom alapját, ha azok a személytelenség és a pártatlanság jegyében mindenkire egyenlően vonatkoznak. Boda \& Medve-Bálint (2012, 29. o.) mindezt - többek között Tyler (2001) alapján - úgy fogalmazza meg, hogy ,az intézményi bizalom egyfajta legitimációs indikátor, amely az adott intézmény »elismerésre méltóságát« jelzi. Az elismerésre viszont az intézmény müködésével kapcsolatos normatív elvárások teljesülése teremti meg az alapot, amelyek közül kiemelkedik az eljárási méltányosság normáinak való megfelelés."38 Hangsúlyozandó persze, hogy ez az elvárás nem kizárólag a kormányzat által kreált formális intézmények, a jogszabályok megalkotására vonatkozik. Amint ugyanis az intézmények korábbi leírásából következik, s ahogyan Győrffy (2012) is utal rá, számos olyan piaci intézmény létezik (hosszú távú szerződések, jogosultságok), amelyek szintén a jövő bizonytalanságát hivatottak csökkenteni. Ezek érvényesítése esetén ugyancsak fontos kritérium a pártatlanság az állami igazságszolgáltatás részéről.

\footnotetext{
${ }^{37}$ Ezt a fajta állami berendezkedést North, Wallis, \& Weingast (2009) az államiság fejlődésének harmadik fázisaként írja le, amely sorrendben az autoritás nélkül müködő anarchiát és a korlátozott hozzáférésü társadalmi rendet müködtető természetes államot követi. Utóbbi jellegzetessége, hogy a társadalmi intézményrendszert biztosító állam már jelen van benne, azonban a harmadik fázissal szemben itt az erőforrások és a jogok még csak a politikai elitet illetik meg. Az intézmények nem egyenlő mércével mérik az elithez nem tartozóakat és az állam még nem tartózkodik feltétlenül az erőszak alkalmazásától, vele szemben a tulajdonjogok és a szerződések még nem kikényszeríthetőek.

${ }^{38}$ Boda \& Medve-Bálint (2012) nem definiálják, hogy pontosan mit értenek méltányosság alatt, ami a fogalom sokszínűsége miatt - lásd Stone (1997) - értelmezésbeli problémákra adhat lehetőséget. Ezt elkerülendő, jelezzük, hogy disszertációnkban a terminust a horizontális és a vertikális méltányosság elveinek kombinált értelmében használjuk, amelyek az azonos helyzetben lévőknek az azonos mércével, a különböző helyzetben lévőknek pedig a különböző mércével történő kezelését kívánják meg (Musgrave, 1959).
} 
Noha a fentiekből világosan látszik, hogy az intézményi bizalom alapvető feltétele a pártatlan és egyenlő elbánás, Boda \& Medve-Bálint (2012) kiemelik, hogy nehéz eldönteni, mi volt előbb: a jól müködő intézmény vagy az abba vetett bizalom. Az ugyanis kétségtelen, hogy az intézményi bizalom e két tényező pozitív visszacsatolási mechanizmusa alapján müködik, egymást erösítik, ami úgynevezett angyali kört indít be. ${ }^{39} \mathrm{Ha}$ az emberek bíznak abban, hogy az intézmények betöltik a szerepüket, azaz szankcionálják a tiltott cselekvéseket, az őket is normakövetésre ösztönzi. Ezzel pedig a jól müködő - szerepüket betöltő, így a mások viselkedésének kiszámíthatóbbá tétele révén a jövő bizonytalanságát csökkentő - intézmények definíciójához térünk vissza (Győrffy, 2017). Ugyanezt erősíti Hurd (1999) érvelése is, mely szerint a szabályok legitimitásának érzete erősebb szabálykövetési ösztönzőként szolgál mind a kényszernél, mind az önérdek-vezérelt költség-haszon számításnál. ${ }^{40}$ Ez másrészről az intézményi bizalom egyik legfontosabb pozitív hozadékának tekinthető. Ráadásul, az ilyen, kiszámítható intézményi környezetnek köszönhetően Hardin (1999) szerint az emberek egymásban is hajlamosabbak lesznek bízni. Így összességében elmondható, hogy az intézményi bizalomnak fontos szerepe van a demokrácia és a közpolitika müködési hatékonyságának növelésében. Mint azt Boda \& Medve-Bálint (2012, 28. o.) kiemelik: „a magasabb szintü intézményi bizalom és legitimitás növeli a kormányzattal vagy az állammal való állampolgári együttmüködés esélyét, és ez hatással lehet a politikai intézmények működésének eredményességére, hiszen könnyebb lesz a törvényeket betartatni, a közpolitikákat végrehajtani."

Álláspontunk szerint a méltányos, legitimitást kivívó, önmaguk iránt bizalmat gerjesztő intézmények erős párhuzamot mutatnak azon vonásokkal, amelyekkel Acemoglu \& Robinson (2013) jellemzik a jó, gazdasági fejlődést támogató, általuk befogadónak (inclusive) nevezett intézményeket. ${ }^{41} \mathrm{E}$ fogalom alatt olyan intézményeket

\footnotetext{
39 Ennek ellentéte lehet a rendszerszintű bizalmatlanság esetén megjelenő ördögi kör, amely az intézményekbe vetett bizalom további romlásával párhuzamosan az ország gazdasági teljesítményét is rontja. Mindezt - gazdaságpolitikai vonatkozásokkal összekötve - Györffy (2014) tárgyalja részletesen.

40 Figyelemre méltó, hogy Hayek $(1991,117$. o.) azt is megemlíti, hogy a „Törvény Uralmának hatékonysága érdekében fontosabb az, hogy legyen egy szabály, amelyet kivétel nélkül mindig alkalmaznak, mint az, hogy mi is ez a szabály”. Noha ezen állítás sok tekintetben vitatható, Hayek azon példával kiegészített érvelése kétségtelenül legitim, mely szerint „mindaddig nem számít, hogy az utak bal vagy jobb oldalán közlekedünk, amíg mindannyian egyformán cselekszünk. A fontos az, hogy a szabályozás képessé tesz bennünket a többiek viselkedésének helyes elörejelzésére, s ez megkívánja, hogy minden esetre alkalmazható legyen, még ha valamelyik konkrét ügyben igazságtalannak éreznénk is". Ez az álláspont valójában egybevág azzal az intézményi müködésre vonatkozó szemlélettel, amelyet jelen disszertációban korábban North (2010) alapján vezettünk fel.

${ }^{41} \mathrm{Az}$ érvelésünkben szereplő párhuzamot erősíti Boda (2016) áttekintése is, aki az intézményi bizalom kapcsán Leventhal (1980) alapján bemutatja a méltányos eljárás kritériumait, s talál olyan jellemzőket
} 
értenek, ,amelyek széles körben osztják meg a hatalmat, gyökerestől irtanának ki minden olyan gazdasági intézményt, amely kisajátítja az erőforrásokat, belépési korlátokat állít, és ellehetetleníti a piacok müködését, hogy a forgalomból csak kevesek profitálhassanak”, ezáltal pedig „biztosítják a erőforrások igazságosabb elosztását” (Acemoglu \& Robinson, 2013, 85-86. o.). ${ }^{42}$ Az ilyen ,jó”, pluralista, korábbi munkájukban a magántulajdon intézményeinek nevezett, intézmények közé többek között a jogállamiság alapját képező törvény előtti egyenlőséget, a tulajdonjogok érvényesíthetőségét, s az esélyegyenlőséget biztosító szabályokat sorolják (Acemoglu, Johnson, \& Robinson, 2005). Ezek ellentétei a kizsákmányoló intézmények, amelyek a jogokat és az erőforrásokat csak egy szűk elit számára tartják fenn, s kizárólag azok gazdagodását szolgálják a társadalom többi részének rovására. ${ }^{43}$ Acemoglu, Johnson, \& Robinson (2001; 2005), illetve Acemoglu \& Robinson (2013) amellett érvelnek, hogy hosszú távon a jó, befogadó intézmények teremtik meg a jólét és a gazdasági fejlődést az egyes országokban, mivel ezek biztosítják leginkább, hogy a gazdasági szereplők maguk is motiváltak legyenek a magas szintü termelésben és az annak nyomán jelentkező felhalmozásban, illetve beruházásban. Továbbá ezek biztosítják a legnagyobb merítési bázist a fejlődés motorjának számító innovációk megvalósulásának is. Ezzel szemben a kizsákmányoló intézményeket működtető államok jobbára csak stagnálásra és hanyatlásra vannak ítélve, ugyanis szabályrendszerük nem biztosít megfelelő ösztönzőket a növekedés beindítására.

Hipotézisünk szerint mindennek a kivándorlási döntésre is hatása lehet. Amint ugyanis Acemoglu \& Robinson (2013) bemutatják, a befogadó intézmények képesek leginkább csökkenteni a bizonytalanságot, s kiszámíthatóságot nyújtani a polgárok számára; ezek teremtik meg annak a lehetőségét, hogy az egyén úgy érezze, a jövőben élvezheti munkája gyümölcsét; s ezek adnak teret annak is, hogy az emberek képességeiket is figyelembe véve - azzal foglalkozzanak, amivel szeretnek. A szándéka szerint racionális önérdekkövető egyén számára tehát szimpatikusabb, s gazdasági

(semlegesség, pártatlanság, elfogulatlanság, az egyén státuszának elismerése, egyenlő elbánás, a jogok figyelembe vétele), amelyek egybecsengenek a befogadó intézményekkel szemben megfogalmazott elvárásoknak. A befogadó intézmények fontosságára egyébként röviden Boda (2016) is utal, ám ezt a bizonytalanságcsökkentő funkciójuk kapcsán teszi meg.

${ }^{42}$ Noha Acemoblus \& Robinson (2013) itt az igazságosság fogalmát említik, valójában - pontosan a fogalom képlékeny jelentéstartalma miatt (lásd Stone, 1997) - közgazdasági szempontból nem ez tekinthető elsődleges szempontnak, hanem a hatékonyság, amelyet a befogadó intézmények a továbbiakban ismertetendő okokból kifolyólag tudnak elősegíteni.

${ }^{43}$ Acemoglu és szerzőtársainak itt bemutatott felosztása szoros gondolati párhuzamot mutat az intézmények azon korábban már tárgyalt distinkcióval, amelyet North, Wallis, \& Weingast (2009) írtak le a természetes és az önkorlátozó állam által müködtetett intézményrendszerekről. 
szempontból is kedvezőbb lehet egy befogadó intézményeket működtető államban élni: az egyenlő elbánás mellett több potenciális lehetőség is áll előtte, ráadásul az ilyen országok rendre magasabb jóléti szintet is kínálnak számukra. Így álláspontunk szerint a befogadó intézményi környezet - az irodalmi áttekintésben használt értelemben vett vonzó tényező, míg ennek ellentéte taszító faktor lehet a migrációban. Tekintve pedig, hogy a befogadó intézmények azok, amelyekben az egyének jellemzően jobban megbíznak ezért egyik hatásmechanizmusként, azt várjuk, hogy az intézmények iránt bizalommal viseltetők kevésbé lesznek hajlamosak az elvándorlásra. ${ }^{44}$

Hipotézisünk szerint emellett az intézményi bizalom egy további, speciálisabb csatornán keresztül is befolyásolhatja az egyén kivándorlási kedvét. Győrffy (2012) szerint ugyanis az intézményi bizalom szintjének a gazdasági szereplők döntéseinek időhorizontjára is érdemi hatása van. Ezen állítását az intézmények korábban már említett kiszámíthatóság-biztosító, bizonytalanság-csökkentő funkcióját tovább gondolva fogalmazza meg. Amint ugyanis levezeti, a megbízható intézmények szabálykövetést generálnak, ami lehetővé teszi a hosszú távú tervezést. Ezzel szemben a megbízhatatlan intézmények szabálykerülésre ösztönöznek, ami a hosszú távú tervezést gátolja, s így a döntést hozók időhorizontját is beszűkítik. A pozitív visszacsatolási mechanizmusok természetesen itt is mindkét esetben müködnek. Mindezt az egyéni szintre levetítve az a következtetés vonható le, hogy akik bíznak abban, hogy az intézmények betöltik a szerepüket, hajlamosabbak lesznek hosszabb távon gondolkodni és tervezni. ${ }^{45}$

Álláspotunk szerint Győrffy (2012) modelljének a migrációs kedv alakítására vonatkozóan is fontos implikációi lehetnek. Mivel a migráció - más oldalról megközelítve, a letelepedéssel járó lakhely-választás - definíciónk szerint egy hosszú távra szóló döntés, ezért feltételezhető, hogy az intézmények megbízhatóságának döntő szerepe lehet benne. A fentiek alapján azt állítjuk, hogy ha az egyén bízik a lakhelye

\footnotetext{
${ }^{44}$ A fent leírtakkal szemben ellenvetésként fogalmazódhat meg, hogy az elithez tartozók számára nem lenne jobb egy befogadó intézményrendszert müködtető államban élni, hiszen számukra az aktuális kizsákmányoló intézményi struktúra a kedvezöbb. Ez azonban csak rövid távon van így. Mint azt North, Wallis, \& Weingast (2009) kifejtik, egy idő után az elit további gazdagodását is az tudja még jobban szolgálni, ha a csere hatókörét kiszélesítik, $\mathrm{s}$ az erőforrásokhoz való hozzáférést lehetővé teszik a társadalom minden tagja számára. Azaz az Acemoglu \& Robinson-féle (2013) terminológia szerinti befogadó intézményrendszer épül ki. Másrészt azonban a fent leírtak rövid távon sem mondanak ellent hipotézisünknek, mely szerint azok, akik bíznak a fennálló intézményekben, kisebb elvándorlási hajlandóságot mutatnak majd. Az elithez tartozók ugyanis várhatóan pont a fennálló kizsákmányoló intézményrendszerben bíznak meg inkább ezért az egyéni szintủ vizsgálatunkban tesztelendő hipotézisünket az indivídumra „ugyanolyan elöjellel” tudjuk megfogalmazni.

${ }^{45}$ Jelen disszertáció fókuszába mindennek az egyéni döntés szintjén megjelenő implikációi tartoznak bele. Az időhorizontra gyakorolt hatás makroszintü, gazdaságpolitikai implikációit Győrffy (2014) tárgyalja részletesen.
} 
szerinti ország intézményeiben, akkor hajlamosabb ott hosszú távon gondolkodni. Ellenkező esetben azonban a jövőt tekintve csak bizonytalansággal szembesül. Győrffy modelljében erre a legszélsőségesebb válasz a szabálykerülés volt, ugyanakkor e modell korlátozott volt abban, hogy a szereplők csak a meglévő kereten belül gondolkodhattak a jövőjükről. A migráció lehetőségének modellbe építésével ebben nyithatunk egy újszerü kaput. Így álláspontunk szerint - kilépve a modell adta keretből, amelyben az egyént körülvevő intézményrendszer exogén adottságként szerepel - az intézmények megbízhatatlanságára az elvándorlás is válasz lehet. Az intézményekbe vetett bizalom mértéke ezáltal egy másik hatásmechanizmuson keresztül is érdemi befolyást gyakorolhat az emberek migrációs szándékára és döntésére.

Összefoglalóan tehát amellett érvelünk, hogy az intézmények számítanak: szerepük van az egyén kivándorlási kedvének és migrációs döntésének alakításában. ${ }^{46}$ Egyrészről ugyanis az intézmények megváltoztathatják a gazdasági szereplők kifizetéseit. Mint az már az irodalmi áttekintésből kirajzolódott, akár egy kiterjedt - vagy ellenkező esetben például egy szükmarkú, esetleg leromlott - jóléti rendszer, akár egy a munkavállalást súlyos adminisztratív terhekkel sújtó szabályozás ösztönzője vagy ellenösztönzője lehet a migrációnak. Az ezek nyomán jelentkező hatások ugyanis gyakran pénzben is kifejezhető módon - beépülnek a migrációs döntést fontolgató egyén azon költség-haszon elemzésébe, amelyet a következő alfejezetben fogunk bemutatni. Az eltérő informális intézmények megismerése és az azokhoz való alkalmazkodás ugyancsak költségként jelentkezhet a migránsok számára. Mindazonáltal álláspontunk szerint az országban müködő intézmények általános jellege, azok müködési méltányossága, funkcionalitási hatásossága, s az ezek révén szerzett legitimitása is döntő fontosságú lehet. Amellett érvelünk, hogy egy befogadó intézményekkel rendelkező származási

\footnotetext{
${ }^{46}$ Megjegyzendő ugyanakkor, hogy az egyén és az intézmények kapcsolata nem egyirányú: amint azt North (2010) is kiemeli, az intézményi változások általában az egyéni cselekvésekre vezethetők vissza. Ennek megfelelően a migrációs döntések is érdemben alakíthatják mind a fogadó, mind a kibocsátó országok társadalmainak intézményrendszerét. Ez jelenthet szabályozói reakciót a formális intézmények terén, de vonatkozhat az informális intézmények természetes evolúciós jellegủ változására is, amely nem is feltétlenül szándékolt következménye az egyéni cselekvéseknek. Előbbiekre példa lehet a bevándorlási szabályok szigorítása a fogadó országban vagy a magyarországihoz hasonló hallgatói szerződések intézményének bevezetése (Golovics, 2015), utóbbiakra pedig többek között a befogadó országok kulturális szabályainak a bevándorlás révén történő változása, alakulása lehet. Mindezek azonban - jóllehet kutatásra érdemes témák - kívül esnek jelen disszertáció vizsgálati fókuszán.
} 
országban az emberek nagyobb bizalmat táplálnak a szabályok iránt, s azon személyek, akik bíznak államuk intézményeiben, kevésbé lesznek hajlamosak az elvándorlásra. ${ }^{47}$

\subsection{Migrációs döntés}

Modellünk szereplöje a 2.1. alfejezetben felvázolt kognitív keretben, az ott lefektetett viselkedési premisszák mentén hozza meg migrációs döntését, amelyet az őt körülvevő intézményi környezet a 2.2. alfejezetben bemutatott módon befolyásol. A döntési mechanizmus először a migráció gondolatának felmerülésével kezdődik, amelyet a keresési folyamat követ, s a végleges döntés ezután születik meg. A következőkben ezen állomásokat mutatjuk be részletesen, amelyet a verbális diszkusszió után a 2.4. alfejezetben a döntés formalizált felírása követ.

\subsubsection{Kiinduló állapot}

Az elvándorlás gondolatának felmerülését nagyban befolyásolják az egyén korábbi tapasztalatai, az őt körülvevő társadalmi közeg, s az, hogy ezáltal milyen mentális modellel rendelkezik. Ezen állításunk a 2.1. alfejezetben leírt viselkedési jellemzőkből következik, ám implikációi összecsengenek a migrációs hálózatok 1.1.7. alfejezetben bemutatott irodalmának konklúzióival. Azt, hogy az ember rendelkezik korábbi külföldi tapasztalatokkal, vagy vannak külföldi kapcsolatai (más országban élő családtagok, ismerősök), úgy definiáljuk, hogy rendelkezik migrációs hálózattal. ${ }^{48}$ Ez már pusztán azáltal növelheti az elvándorlás valószínűségét, hogy a kognitív korlátokkal rendelkező egyén választási lehetőségei között - például azért, mert a korábban külföldre vándorlókkal közös mentális modellel, ezáltal gondolkodási rendszerrel rendelkezik egyáltalán felmerül ez az alternatíva. A migrációs hálózatok meglétének tehát ez az egyik csatornája, amelyen keresztül hatással bírhat a migrációs kedv alakítására - a másikat a keresési folyamat leírása kapcsán tárgyaljuk részletesen. Emellett, mint azt a 2.2. alfejezetben szintén levezettük, a rossz intézményi környezet ugyancsak megérlelheti azt a gondolatot, hogy az egyénnek esetleg külföldön kell terveznie a jövőjét. Mindazonáltal számos további forrás lehet a migráció gondolatának a megjelenésére - kezdve a

\footnotetext{
${ }^{47} \mathrm{Az}$ intézmények vonzó-taszító jellegének megléte intuitíve mind a fogadó, mind a származási ország esetében feltételezhető. Elméleti modellünkben azonban a hatást csak utóbbi kapcsán tárgyaljuk. Erre elméleti okunk az, hogy az intézményi minőség hatását az intézményi bizalmon keresztül vizsgáljuk, amit egy tapasztaláson alapuló attitüdnek tekintünk. A potenciális migránsnak pedig lehetnek ugyan hallomásai, elképzelései a célország intézményeiről, ezeket a várakozásokat - hacsak az illető nem élt ott korábban nem tekinthetjük ekvivalensnek az intézményi bizalommal.

$48 \mathrm{Ez}$ természetesen fogalmi egyszerüsítésnek tekinthető, hiszen ezek a kapcsolatok és az általuk realizálható előnyök eltörpülnek mindattól, amit egy teljes hálózat rejthet, s amiket a kutató egy hálózatot egészében, „felülnézetből” vizsgálva találhatna.
} 
médiában látott információfoszlányoktól az idegennyelv-tudás meglétén át egészen a tényleges munkaerőpiaci kudarcokig.

\subsubsection{Keresés és tranzakciós költségek}

A keresés kapcsán fontos megjegyezni, hogy a migráció - amelyre disszertációnkban egy külföldi munkavállalással járó cselekvésként gondolunk közgazdasági értelemben nem jelent mást, mint hogy a piac határokon átívelve allokálja a munkaerőt. Maga a munkavállalás - vagy ha úgy tetszik, a munkaszerződés megkötésének - aktusa is egy piaci tranzakció. Emellett a migráció révén elinduló új életszakasz elengedhetetlen feltétele egy új lakhely, megtalálás, kiválasztása és az ott történő letelepedés is. Ez történhet saját ingatlan vásárlásával, bérléssel, sőt akár valamilyen sajátos konstrukcióban is (például vendégmunkás-szállón), de mindenképpen egy - jelentős részben a piaci ármechnanizmus segítségével történő - tranzakció lebonyolítását igényli. A jóléti közgazdaságtan első tétele alapján tudjuk, hogy amennyiben a piac tökéletesen müködik, akkor - a piaci allokáció Pareto-hatékony (Stiglitz, 1991). Ugyanakkor Coase (1937) nyomán az is alapvetésnek számít, hogy a piaci ármechanizmus használata költséges. Ezeket, a tranzakciók lebonyolításához kapcsolódó - a termelési költségek fedezését célzó, a partnernek fizetett áron felül jelentkező - járulékos költségeket tranzakciós költségnek nevezzük, amelyek Williamson (1985) hasonlatával élve egyfajta súrlódást visznek a rendszebe. Arrow (1969) egyszerüen a gazdaság müködtetésének költségeiként definiálja őket. Ezt Furubotn \& Richter (2005) azzal egészíti ki, hogy a társadalmi rendszer müködtetésének költségeit is közéjük sorolja. ${ }^{49}$

\footnotetext{
${ }^{49}$ A tranzakciós költségek egzakt és átfogó definiálása valójában nagyobb nehézséget jelent a közgazdásztársadalom számára, mint a fogalom tartalommal történ feltöltése, s jelentőségének tárgyalása a gazdasági folyamatokban. Ironikus, hogy az egész elméletét a tranzakciós költségekre építő Williamson (2007, 253. o.) a talán legátfogóbb tanulmányában a „verbális definíciók hiányát” említi a tranzakciós költség alapú megközelítés egyik fontos korlátjaként, ám ennek megfogalmazására a szóban forgó írásban ő sem tesz kísérletet. A glosszáriumok és a kézikönyvek túl általános (Furubotn \& Richter, 2005; Milgrom \& Roberts, 2005) definíciói mellett túl szük (Niehans, 1987) értelmezésekkel is találkozhatunk. Ez a kettősség többnyire abból ered, hogy egyes szerzők - például Pejovich (1992) - definíciója kizárólag a piaci tranzakciós költségekre vonatkozik, amelyek azonban, mint azt később bemutatjuk, a tágabb értelmezésben csak az egyik típusát jelentik a tranzakciós költségeknek. A különböző definíciós kísérletekkel párhuzamosan - amelyekhez további adalékokkal szolgálhat Dahlman (1979) korai áttekintése a fogalom értelmezéseiröl - az is megfigyelhető, hogy bizonyos szerzők jobbára a tranzakciós költségek típusainak, megjelenési implikációinak és jellemzőinek taxatív felsorolásával adtak jelentést a terminusnak (Eggertsson, 1990; Furubotn \& Richter, 2005; North, 2010). Noha a fentiekben mindezek ötvözésével mi is kísérletet tettünk egy átfogó definíció megalkotására, a továbbiakban jobbára az utóbb hivatkozott szerzök módszere révén kívánjuk tárgyalni a témát. Ennek talán épp Eggertsson (1990) azon szellemes megjegyzése adhat indirekt legitimációt, mely szerint valójában a termelési költségek sincsenek jól definiálva a neoklasszikus modellekben.
} 
A tranzakciós költségek koncepcióját Coase (1937) emelte be a közgazdaságtudományba. A fogalom alatt a piaci tranzakciók megszervezésének költségeit értette, bár arról is beszélt, hogy a tranzakciók vállalaton belül történő megszervezése is költséges. ${ }^{50}$ Előbbiek közé az árak felderítésével járó terheket, valamint a szerződések letárgyalására és rögzítésére fordított erőforrásokat sorolta. Később így fogalmazta meg mindezt: „annak érdekében, hogy végrehajthassunk egy piaci tranzakciót, ki kell derítenünk, kivel is akarunk kapcsolatba lépni; az emberek tudomására kell hoznunk, hogy bizonyos feltételek mellett üzletet szeretnénk velük kötni; tárgyalni kell, amíg el nem jutunk a végső alkuig, le kell fektetni a szerződést; ellenőrizni kell, vajon a másik fél betartja-e a szerződésben megállapított kötelezettségeit és így tovább" (Coase, 1960, 15. o.). ${ }^{51}$ A felderítési költségek kapcsán fontos hangsúlyozni, hogy azok létét Coase - jóval Simon előtt, de ugyanúgy tudatosan szembe menve a korabeli közgazdasági modellek állításaival - abból vezette le, hogy gazdasági szereplők a valóságban nyilvánvalóan nem ismernek minden releváns árat. Így megállapíthatjuk, hogy elméletében a tranzakciós költségek egyik fajtájának megjelenése az emberi agy kognitív képességeinek korlátaira, a mindentudás hiányára vezethető vissza - azt pedig, hogy a tranzakciók lebonyolítását keretbe foglaló szerződésekre is emiatt van szükség, már Williamson dolgozta ki. ${ }^{52}$

Williamson $(2000 ; 2010)$ munkásságának központi fogalma a tranzakciós költség: az új intézményi közgazdaságtan általa müvelt irányzatát a tranzakciós költségek gazdaságtanának (transaction cost economics) nevezi. Ez azonban kevésbé maguknak a tranzakciós költségeknek a tárgyalásáról szól, sokkal inkább egy szemléletmódot jelent (transaction cost approach), amely a jelenség figyelembevételének, a modellekbe történő bevezetésének következményeire, s a jelenlétükre adott reakciók vizsgálatára fókuszál. A fogalom felvezetésekor Williamson (1985) is Arrow definícióját használja, s a termelési költségeken kívül eső költségtípusnak nevezi őket, amelyek lényegében a fizika súrlódásának gazdasági megfelelői. Elmélete a tranzakciók lebonyolításának módját helyezi középpontba, s tekintve, hogy a gazdasági tevékenységek megszervezésének

\footnotetext{
${ }^{50}$ Ez azért hangsúlyozandó ki, mert a vállalaton belüli megszervezés költségei az általunk később ismertetendő tipológiában ugyancsak a tranzakciós költségek egy típusának tekinthetők.

${ }^{51}$ Fordítás: Coase, R. H. (2004): A társadalmi költség problémája. In: Coase, R. H.: A vállalat, a piac és a jog. Budapest: Nemzeti Tankönyvkiadó. 163. o.

${ }^{52}$ A tranzakciós költségek létének leírásával Coase (1937) a vállalatok létezésének okára kívánt rámutatni, azaz arra, hogy egyes tranzakciók megszervezését a gazdasági szereplők miért a hierarchián belül, s nem a hatékonynak gondolt piacon végzik. Ezzel azonban arra is felhívta a figyelmet, hogy a tranzakciós költségek léte gátja lehet a hatékony piaci allokációnak. Ezt még direktebb módon Coase (1960) mondta ki, ahol amellett érvelt, hogy tranzakciós költségek hiányában - ha a tulajdonjogok megfelelően definiálva vannak - a piac nem vallana kudarcot az externáliák alkuval történő megoldásában.
} 
kérdését egy szerződés(kötés)i kérdésnek tartja, azt vizsgálja, hogy a különböző szerződési módok milyen költségekkel járnak. Ezeket, a tranzakciók intézményi keretének kialakítására fordított erőforrásokat tekinti tranzakciós költségnek. Két típusukat különbözteti meg: az ex ante és az ex post tranzakciós költségeket. Elöbbiek közé a szerződés megszövegezésére, letárgyalására és a biztosítékok kialakítására (safeguarding) fordított erőforrásokat sorolja. Minél többet áldoznak erre a felek, a szerződés annál teljesebb lesz, viszont ez értelemszerüen több ráfordítással is jár. Az ex post tranzakciós költségek közé a változásokhoz való alkalmazkodás, az irányítási struktúra felállításának és müködtetésének költségei és a szerződés kikényszerítési költségei tartoznak meghatározása szerint.

Williamson (2007, 243. o.) megfogalmazásában „a tranzakciós költségek csökkentése egyet jelent a korlátozott racionalitásból fakadó költségek csökkentésével és az opportunizmus kockázataival szembeni védelemmel”. Ezzel a tranzakciós költségeket implicite a racionalitás korlátozottságának költségének nevezi. Ez több lépcsőben is levezethető az elméletében. Mint azt a 2.2. alfejezetben tárgyaltakkal összhangban írja, irányítási struktúra létrehozására bizonytalanság esetén van szükség. Utóbbinak két fajtáját különbözteti meg: az elsődleges (külső) bizonytalanságot, amely a világ és a jövő ismeretlenségéből fakad és a másodlagos (viselkedési) bizonytalanságot, amely a partner esetleges opportunizmusának lehetőségére vezethető vissza. Mindezek pedig közvetlenül a modelljének viselkedési előfeltevéseire reflektálnak: rendre a korlátozott racionalitásra és az opportunizmusra (Williamson, 1985).

Mindazonáltal hangsúlyozandó, hogy mivel Williamson az exogénen módon adott, lebonyolítandó tranzakciók megszervezési módjára fókuszál, az, hogy a tranzakcióban részt vevő felek hogyan jutnak el idáig, s miként találnak egymásra, nem képezi vizsgálatának tárgyát. Sokat hangsúlyozott viselkedési előfeltevései azonban csak impliciten ugyan, de - élesen irányt mutatnak erre vonatkozóan is: ha az egyén korlátozott ismeretekkel rendelkezik a valóságról, s a benne lévő potenciális partnerekről, akkor utóbbiak felkutatására is kétségkívül erőforrásokat - tranzakciós költségeket - kell szánnia. Az pedig, hogy állítása szerint ,az információ hatékony feldolgozása fontos vizsgálódási szempont” a tranzakciós költségek tanulmányozásában (Williamson, 2007, 235. o.), annak tényét is megerősíti, hogy az információt nem csak felkutatni, de feldolgozni (megérteni, a meglévő gondolatok között rendszerezni) is költséges.

Egy másik perspektívából ugyan, de a fentiekhez hasonlóan gondolkodik North $(1987 ; 1990 ; 2010)$ is a tranzakciós költségekröl. Ö a tranzakciókhoz kapcsolódó 
felmérési és érvényesítési költségeket érti a fogalom alatt. Előbbiekhez a kiindulópontot természetesen nála is az informáltság tökéletlensége adja. Mint azt a fogyasztással kapcsolatban megfogalmazza: „haszon az áru vagy szolgáltatás különféle jellemzőiböl származik [...]. Erőforrásra van szükségünk, hogy megmérjük ezeket az attribútumokat, és további erőforrásokra, hogy meghatározzuk és megmérjük az átruházott jogokat" (North, 2010, 55. o.). ${ }^{53}$ Emellett azt is megjegyzi, hogy a cserében részt vevő feleknek gyakran még a partner tartózkodási helyéről is információkat kell szereznie. Egyszerüen fogalmazva tehát: a piaci döntések meghozatalához az egyénnek informálódnia kell, ami tranzakciós költségekkel jár. Emellett North-nál is megjelennek a korábban már tárgyalt, szerződéskötéssel és annak érvényesítésével járó - felügyeleti, kikényszerítési és a tulajdonjogok megvédésével járó - további terhek is. Álláspontja szerint a gazdasági müködésben ezek is jelentős tételt képviselnek. Ezért a hagyományos termelési költségeken, a termelési tényezőknek ,az áruk fizikai jellemzőinek [...] megváltoztatására" irányuló erőforrás-ráfordításain túl mind a gazdasági szereplőknek, mind a kutatóknak figyelmet kell fordítania „az árukkal kapcsolatos tulajdonjogok [...] meghatározására, védelmére és érvényesítésére" irányuló tranzakciós költségekre is (North, 2010, 53-54. o.). Ezek együtt jelentik ugyanis a gazdasági működés teljes költségét.

Noha a tranzakciós költségeket North (2010) is a racionalitás korlátozottságából eredezteti, mértéküket, álláspontja szerint a technológiai fejlettség és az intézmények határozzák meg. Előbbi értelemszerüen a fejlődése révén tudja csökkenteni mind a keresési, mind az érvényesítési költségeket, utóbbiaknak pedig - összhangban a 2.2. alfejezetben leírtakkal - definíciószerűen ez a funkciójuk. Mindezek kapcsán persze megjegyezhető, hogy North ezt saját kutatási programjának tükrében fogalmazta meg, amelynek célja a gazdasági teljesítmény és az intézmények kölcsönhatásának leírása. $\mathrm{E}$ tekintetben pedig - hasonlóan Coase (1960) megközelítéséhez - a tranzakciós költségeket a hatékony allokáció, s ezáltal a fejlődés egyik gátjaként látja. Ezért, álláspontja szerint a termelékeny gazdaságok megteremtésének kulcsa az, hogy olyan intézményeket hozzunk létre, amelyek alacsony tranzakciós költségek mellett biztosítják a piaci cserék lebonyolítását (North, 1987).

\footnotetext{
${ }^{53}$ Utóbbi kitétel kapcsán North (1990) máshol még egyértelmübben fogalmaz, jelesül, hogy a potenciális vásárlónak a fizikai tulajdonságok mellett a jószág vagy szolgáltatás tulajdonjogi aspektusait is fel kell mérnie.
} 
Összefoglalóan azt mondhatjuk, hogy mindezek összhangban vannak Eggertsson (1990, 15. o.) azon megállapításával, mely szerint ,a tranzakciós költségek így vagy úgy a cserére vonatkozó információk megszerzésével állnak összefüggésben”, amely felfogás egyébként éles ellentétben áll a korábbi modellek teljes informáltságra vonatkozó feltevésével. $^{54}$ Ez a kijelentés azonban jobbára csak a piaci tranzakciókra vonatkoztatható, míg az irodalom egy része ma már szélesebb fókusszal vizsgálja a témát. Áttekintésükben Furubotn \& Richter (2005) három típusát különböztetik meg a tranzakciós költségeknek. (i) A piaci tranzakciós költségek közé - a korábban tárgyaltakkal megegyező jelentéstartalommal - a keresési és informálódási, az alkudozási és megegyezési költségeket, illetve a felügyeleti és kikényszerítési költségeket sorolják. Itt említik még a társas kapcsolatokba történő beruházást is, amelyről eddig még nem volt szó. Ezen tevékenység alatt az emberi kapcsolatok kialakításába invesztált erőforrásokat értik, amelynek a Coleman-féle (1988) értelemben vett, együttműködést megkönnyítő társadalmi tőke létrehozása a célja. (ii) Irányítási (managerial) tranzakciós költségek alatt a szervezeteken belül megszervezett tranzakciókhoz kapcsolódó terheket értik, így a szervezeti struktúra kialakításával és fenntartásával kapcsolatos költségeket, a szervezeten belüli jószág- vagy szolgáltatás-átadás költségeit, illetve a megbízó-ügynök probléma terheit tartják itt számon. (iii) A politikai tranzakciós költségek fogalma pedig a társadalmi és politikai intézményrendszer megszervezésének, fenntartásának és müködtetésének költségeire utal. ${ }^{55}$

Álláspontunk szerint tranzakciós költségek - amelyet a jelen alfejezet elején általunk megfogalmazott meghatározás szerint, valamint az alább kifejtendő tartalommal értelmezünk - az elvándorlás kapcsán is jelen vannak. A migrációs döntést megelőző keresés önmagában ilyen ráfordítás lehet. Ezek között akár említhetnénk a célhely megválasztásához kapcsolódó általánosabb - például az élet- és bérszínvonalra vagy a munkaerőpiai szabályozásokra vonatkozó - felmérési költségeket, de fogalmilag helyesebb, ha a migrációhoz kapcsolódó, korábban már említett, munkavállalás, illetve lakhelyválasztás konkrét tranzakcióit közvetlenül érintő információgyüjtési és -

\footnotetext{
${ }^{54}$ Eggertsson (1990) véleménye szerint egyébként pont ez a viselkedési feltevés beli különbözőség volt az oka annak, hogy a tranzakciós költségek gondolata csak „késve” jelent meg a közgazdasági elméletben.

${ }^{55}$ Pejovich (1992) alapján megjegyezzük, hogy ide tartozik az igazságszolgáltatás fenntartásának költsége is, amelynek feladata a tulajdonjogok és szerződések kikényszeríthetőségének biztosítása. Így egy jogosultság vagy szerződés bíróság útján történő érvényesítésekor nem csak az egyéni szinten megjelenő tranzakciós költségekre kell gondolni, hanem azt is figyelembe kell venni, hogy az eljáró bíróság fenntartása is erőforrás-ráfordítással jár.
} 
feldolgozási költségekre fókuszálunk. ${ }^{56}$ Ezeket a Furubotn \& Richter (2005) kategorizálása szerinti piaci tranzakciós költségeken belül definiált keresési és informálódási költségek közé sorolhatjuk. Emellett a társas kapcsolatokba történő beruházás jelentkezhet még a potenciális elvándorlók számára akkor, ha a keresési folyamatot azzal kívánják megkönnyíteni, hogy a migrációs hálózatokban rejlö lehetőségeket kihasználandó, megismerkednek és kapcsolatot teremtenek bizonyos külföldön élő - korábbról nem ismert - személyekkel. ${ }^{57}$ Mindezek szerepeltetését disszertációnkban is az igazolja, hogy modellünk szereplőiről korlátozott racionalitást tételeztünk fel.

Modellünkben a tranzakciós költségek jelentősége abban rejlik, hogy a keresési folyamat befolyásolása révén a végső döntésre is hatással vannak. Persze, mint azt korábban már hangsúlyoztuk, nem azért, mert az egyén egy Stigler-féle (1989) optimális keresési folyamatot futtatna. Annál is inkább, mivel keresési köreit saját mentális modellje, illetve különböző heurisztikák alapján futtatja, így elsősorban eleve a könnyen - értsd alacsony tranzakciós költségekkel - elérhető alternatívákat veszik számításba. Viszont, ha a tranzakciós költségek valamilyen okból alacsonyabbak a korlátozottan racionális egyén számára, akkor több és/vagy jobb döntési variánst tud felkutatni, így várhatóan nagyobb eséllyel talál a helyben maradásnál jobb alternatívát. Ezáltal korlátozott racionalitással sújtott döntése várhatóan az ovjektíve vett optimumhoz is közelebb lesz majd.

A tranzakciós költségek csökkentésében egyrészt - mint arra North (2010) nyomán utaltunk - a technológia lehet az egyén segítségére. Az infokommunikációs technológia fejlődése az elmúlt évtizedekben drasztikusan csökkentette a tranzakciós költségeket a gazdaság és a társadalmi együttélés valamennyi szektorában (Hámori, 2013). Ezek - ahogyan azt már Lee (1966) is prediktálta - számos olyan tényezőt érintettek, amelyek a migrációhoz kapcsolódó tranzakciós költségeken is faragtak. Ebben föként az internet adta lehetőségek járnak élen: a világhálón ugyanis ma összehasonlíthatatlanul könnyebb mind az állás-, mind a lakóhelykeresés, mint akár csak

\footnotetext{
${ }^{56}$ Noha mindez csak definíció és értelmezés kérdése lehet, mint azt Eggertsson (1990) megjegyzi, az informálódási költségek önmagukban nem egyenlöek a tranzakciós költségekkel. Utóbbiakat ugyanis az különbözteti meg az előbbiektől, hogy tényleges, valamilyen partner „közremüködését” is igénylő tranzakcióhoz kapcsolódnak. Szemléltető példaként egy lakatlan szigeten élő ember példáját hozza fel, aki gyüjthet ugyan költségesen információt, de az partner és tranzakció hiányában nem tekinthető tranzakciós költségnek.

${ }^{57}$ Maguknak a - munkavállalási és lakhelyválasztási - tranzakcióknak a lefolytatása során természetesen a piaci tranzakciós költségek további fajtái is megjelennek, ennek részletes bemutatása túlmutat a jelen, keresési folyamatról szóló rész keretein, emellett pedig empirikus vizsgálatunknak sem képezi majd tárgyát.
} 
tíz évvel ezelőtt, de ugyanez igaz a potenciális partnerekkel való kommunikációra is. Így egy egyszerű példával élve azt mondhatjuk, hogy az infokommunikációs technológia vívmányaihoz, például az internethez hozzáférők, alacsonyabb tranzakciós költségekkel tudnak keresni, ami az elvándorlási esélyeiket is növelheti. Mindezt azzal a megfigyeléssel is kiegészíthetjük, hogy a nagyvárosok lakóinak ezek a lehetőségek inkább adottak, mint a vidéken élők számára. Ennek az implikációja az lehet, hogy utóbbiak - legalábbis a nagy átlagok szintjén - ceteris paribus alacsonyabb tranzakciós költségekkel szembesülhetnek a keresés során, ami egyfajta magyarázatul szolgálhat nagyobb elvándorlási hajlandóságukra.

A másik, migrációs irodalom alapján kiemelendő tényező, amely befolyásolhatja a tranzakciós költségek mértékét, a hálózatok léte. Arra az imént már utaltunk, hogy a hálózat tagjává válni első lépésben - a társas kapcsolatokba történő beruházás révén még éppen tranzakciós költségekkel járhat, de ez később jó eséllyel megtérülhet. Amint ugyanis az 1.1.7. alfejezetben tárgyaltuk, a hálózat jelentős segítséget nyújthat tagjainak mind a megfelelő lakhely, mind a megfelelő munkalehetőség megtalálásában. Ráadásul, ha az egyén költségmentesen tesz szert olyan kapcsolatokra, amelyek révén ezeket a hatásokat ki tudja aknázni, az még kedvezőbb a számára. Ilyen hálózati kapcsolatokkal akkor rendelkezhet, ha például korábban már élt vagy dolgozott huzamosabb ideig külföldön, s ott egy személyes ismeretségi kört épített ki magának, illetve, ha barátai, ismerősei vagy családtagjai éltek vagy élnek másik országban.

A migráció kapcsán kiemelhető még egy tényező, amely érdemben befolyásolja a keresés folyamatát, s annak tranzakciós költségeit: ez pedig a potenciális elvándorló idegennyelv-tudása. Egyrészről, mint arra már utaltunk, egy nyelvismerettel rendelkező egyénben eleve nagyobb valószínüséggel merülhet fel a kivándorlás gondolata, $\mathrm{s}$ az is vélelmezhető, hogy a heurisztikus keresés során azokat a célországokat veszi számításba, amelyeknek a nyelvét beszéli. Ez már önmagában behatárolhatja a lehetséges variánsok körét, s ezáltal akár a végső döntés eredményét is meghatározhatja. Emellett a nyelvtudás megléte magának a keresési folyamatnak a nehézkességét, időigényességét is befolyásolja: egy idegen nyelvet beszélő egyén ezáltal várhatóan munkát és szállást is alacsonyabb tranzakciós költséggel tud találni külföldön.

Miután az egyénben megfogalmazódott az elvándorlás gondolata, s a fentiekben leírt keresési folyamat során felmérte az előtte álló lehetőségeket, döntését a 2.1. alfejezetben vázoltak szerint hozza meg: a „menüben szereplő” variánsok közül azt választja, amely szubjektív értékítélete szerint a legnagyobb hasznossági szintet biztosítja 
számára. A következő alfejezetben azokat a tényezőket mutatjuk be, amelyeket ezen összehasonlítás során vesz számba.

\subsubsection{Döntési szempontok: standard tényezők}

A migrációs döntés meghozatalakor az egyén értékeli és összehasonlítja mindazokat a standard - többnyire anyagi formában is kifejezhető - tényezőket, amelyek Sjaastad (1962) óta részét képezik a nemzetközi vándorlások mikroökonómiai elemzési keretének, s amelyeket az irodalmi áttekintésben részletesen bemutattunk. Így modellünk is abból indul ki, hogy a potenciális migránsnak alapvetően gazdasági jellegủ motivációi vannak, tehát a magasabb jólét érdekében veheti fontolóra a külföldre költözést.

Modellünk szereplőjének tehát fontos a potenciális célterületeken számára elérhető életszínvonal. Ezt többek között az általa elérhető bérek nagysága határozza meg (figyelembe véve az árszínvonalat is), amelyet a célterület általános bérszínvonala mellett saját humántőkéjének minősége is befolyásol. Előbbi kapcsán természetesen az sem elhanyagolható, hogy várhatóan van-e esélye munkába állni: a munkaerőpiac telítettsége ezért ugyancsak fontos szempont lehet számára.

A piacon megszerezhető jövedelem mellett az is fontos szempont az aktornak, hogy a kormányzattól milyen további juttatásokban részesülhet, vagy ellenkezőleg az milyen terheket ró rá. A túlságosan magas adók elrettenthetik, míg a bőkezü jóléti rendszer - beleértve ebbe a munkanélküliség esetén nyújtott járadékokat - vonzó lehet a potenciális migránsok számára. Mindemellett a célhelynek lehetnek további olyan jellegzetességei (például földrajzi helyzet, klíma, technológia révén elérhető javak vagy szolgáltatások), amelyek ugyancsak pozitív irányban befolyásolják az egyén hasznosságát.

Ezen hasznok többsége ugyanakkor nem (csak) a „migráció pillanatában”, hanem az egyén életének hátralevő részében érezteti hatását, ezért e tételnél az irodalomban általában az élethosszig tartó jövedelemáramlások diszkontált jelenérétével szokás számolni. Jelen disszertáció korlátozottan racionális aktoráról azonban nem (feltétlenül) feltételezünk ilyen jellegű számítási képességeket. A szándéka szerint racionális egyén ugyan tisztában van azzal, hogy a migrációtól várt haszon-többlet hosszabb időszakon jelentkezik majd, azt azonban nem feltételezzük, hogy erre vonatkozóan precíz matematikai, illetve gazdasági számításokat tud végezni. Így a migrációtól várt hasznokra a továbbiakban úgy tekintünk, mint amelyek tartalmazzák az élethosszig tartó haszonáramlásokat, ám azok - szemben például a Todaro-féle (1969) megközelítéssel - nem a 
valószítnűség- és jelenértékszámítás szabályai, hanem az egyén szubjektív megítélése és prognózisai szerint összegződnek.

Mindezen hasznokat a mobilitás költségei ellensúlyozhatják. Jelen disszertáció elméleti modelljében ezeket élesen elkülönítjük a migrációhoz kapcsolódó tranzakciós költségektől (részletesen lásd alább), s előbbiek közé csak a vándorlás tényleges reálköltségeit soroljuk. Így a mobilitási költségek között jobbára az utazás és költözés költségeit, az ehhez kapcsolódó vásárlásokat, valamint az egyéb ilyen jellegü direkt pénzbeli kiadással járó tételeket tartjuk számon.

A keresés során felmerülö, 2.3.2. alfejezetben bemutatott költségeket nem soroljuk a mobilitás költségei közé. Hangsúlyozandó azonban, hogy - mint arra utaltunk - a migráció, s az ahhoz kapcsolódó lakhatási, illetve munkavállalási tranzakciók során jelentkezhetnek további tárgyalási és kikényszerítési tranzakciós költségek. Ezek mértékét szintén jelentősen befolyásolja az egyén nyelvtudása, ezért idegennyelv-ismeret hiányában várható mértékük elrettentő nagyságú is lehet. Megjegyezzük továbbá azt is, hogy ilyen jellegű - az idegennyelv-ismeret által meghatározott - tranzakciós költségekkel az egyén nem csak az egyszer, a migráció alkalmával, hanem az azt követő mindennapi élet során lebonyolított tranzakciókban (például a napi bevásárlásban) folyamatosan szembesülhet, amivel szintén számolhat a döntés meghozatalakor.

\subsubsection{Döntési szempontok: specifikus beruházások}

Az empirikus irodalom áttekintése során világosan kirajzolódott, hogy vannak olyan egyedi jellemzők, amelyek mentén jól elkülöníthetők az elvándorlásra hajlamosabb és kevésbé hajlamos személyek. Ilyen lehet például, hogy az egyén rendelkezik-e saját lakással, illetve, hogy egyedülálló-e. Az egyértelmü empirikus bizonyítékok ellenére azonban ezen tanulmányok nem szolgáltak egységes és átfogó közgazdaságtani megalapozottságú elmélettel mindezek magyarázatára. Jelen disszertációban ezt a specifikusság és a specifikus beruházások fogalmának beemelésével tesszük meg. ${ }^{58}$

A specifikusság fogalma arra utal, hogy egy eszköz milyen mértékben csoportosítható át egy alternatív használatra vagy alternatív használóhoz anélkül, hogy veszítene produktív értékéből (Williamson, 1991). Ennek megfelelően a specifikus beruházások definíció szerint olyan eszközöket hoznak létre, ,amelyek értéke jóval nagyobb egy adott felhasználásban vagy kapcsolatban, mint a következő legjobb

\footnotetext{
${ }^{58}$ A specifikusság jelenségére másként az idioszinkrázia kifejezéssel utalhatunk, a specifikus beruházásokat pedig nevezhetjük idioszinkratikus, kapcsolat-, reláció- vagy tranzakcióspecifikus beruházásoknak is. A továbbiakban ezeket szinonimaként használjuk.
} 
alternatíva esetén” (Milgrom \& Roberts, 2005, 788. o.). Jelentőségük pedig abban rejlik, hogy a specifikus eszköz az adott „kapcsolaton [vagy felhasználáson] kívülre kerülve veszít az értékéből” (Mike, 2008, 6. o.).

A specifikus beruházásoknak Williamson (1985) hagyományosan négy fajtáját különböztette meg, (i) a specifikus fizikai eszközt, (ii) a specifikus humán tőkét, (iii) a specifikus helyszínt és (iv) a dedikált eszközt. Ezen kategorizálást később (v) a márkanévből eredő tőke és (vi) az időbeli specifikusság fogalmával egészítette ki (Williamson, 1991). A specifikus fizikai eszközre egy különleges gép szolgálhat példaként, amely csak egy adott partner számára hasznosítható produktumot gyárt. Specifikus humán tőkére példa lehet egy adott munkakörben tapasztalással megszerzett, más munkakörbe azonban át nem vihető tudás ${ }^{59}$. A helyszín specifikusságát a partner közelsége adhatja, például egy, az alacsony logisztikai költségek kihasználása érdekében a közvetlen a partner szomszédságába épített üzem esetén. Dedikált eszközök alatt olyan tételeket értünk, amelyek önmagukban nem lennének specifikusak, de az adott partnernek szánt nagy mennyiségü megvásárlásuk vagy előállításuk révén mégis relációspecifikussá válnak. A márkanévből eredő tőke kapcsán a brandépítésre fordított beruházásokra gondolhatunk, az időbeli specifikusság jelensége pedig - amely Masten, Meehan, \& Snyder (1991) munkájából eredeztethető - akkor lép fel, amikor egy munkafolyamat időzítése kritikus szempont, s a késés különösen jelentős kárt tud okozni a termelésben.

Ezeknek a specifikus beruházásoknak azért van jelentősége a gazdasági müködésben, mert a nehézkes alternatív hasznosíthatóság miatt az érintett felek érdekeltek lesznek a hosszú távú együttmüködésben, ennek hiányában ugyanis a specifikus eszközre fordított kiadások elsüllyedt költséggé válnának. Ez az egymásra utaltság azonban egyúttal az opportunizmus megjelenésének is teret adhat, amely ellen az jelenthet védekezést, ha a tranzakciót nem a klasszikus piaci keretek között, hanem valamilyen speciális irányítási struktúrában bonyolítják le. Így ez a kiindulópont kiegészítve azzal, hogy a különböző irányítási struktúrák különböző mértékü irányítási

\footnotetext{
59 A specifikusság ezen formája Williamson $(1985 ; 2007)$ szerint nagymértékben rokonítható azzal a jelenséggel, amelyet Michael Polanyi (1962) a személyes tudás kifejezéssel írt le. Utóbbi a képzett munkaerő személyiségébe beágyazódott tudásra és készségekre utal, amelynek mások általi megismerési és kinyerése csak rendkívül nehézkesen lehetséges, egyes esetekben pedig teljesen lehetetlen. Ezzel párhuzamosan a specifikus humántőke terminusa jól reflektál arra is, amit Hayek (1945) fogalmazott meg a tudás kapcsán: jelesül, hogy az adott hely és idő adta sajátosságokat mindig csak a helyben lévők ismerik, s az általuk birtokolt tudás pontos összegyüjtése a gyakorlatban súlyos akadályokba ütközne.
} 
költséggel járnak - ágyaz meg a különböző szerződéstípusok, s maga a vállalat létrejöttének is (Riordan \& Williamson, 1985; Williamson, 1985; 2007). ${ }^{60}$

A specifikus beruházások léte tehát képes hozzákötni az őket meghozó gazdasági szereplőket egy adott partnerhez. Ennek pedig álláspontunk szerint a migráció kapcsán is jelentősége lehet.

Irodalmi áttekintésünk 1.1.3. alfejezetében már részleteztük, hogy DaVanzo (1981a; 1981b), Haug (2008), illetve Mulder \& Wagner (2012) is használt egyfajta helyspecifikus töke fogalmat a migrációs döntések tárgyalásakor. Ahogyan ezt ott jeleztük, s mint az az alábbi leírásból is kirajzolódik majd, az általuk leírt hatásmechanizmus hasonlít disszertációnk specifikusság fogalmához, azonban ők nem az intézményi közgazdaságtan terminológiai keretében használták azt.

A Williamson-féle specifikusság fogalmát Mike (2008; 2009; 2012) használta jelent disszertáció témájához köthető összefüggésben. Mike a föderalizmus gazdaságtani irodalmába ágyazva, EU-s kontextusban vizsgálta a Hirschman-féle (1995) kivonulástiltakozás-hüség trilemma alkalmazhatóságát. Fogalomrendszerében a hirschmani kivonulás terminusát felelteti meg a más országba való áttelepülésnek. Ebben a keretben a politikai közösséghez füződő hüség kapcsán - annak egy lehetséges forrásaként tárgyalja, hogy a specifikus beruházások léte miként hat a kivonulási és tiltakozási alternatívákra. Ezen munkák jelen disszertáció számára is inspirációiként szolgáltak, s több állításukat is továbbgondoljuk. Jelentős különbség azonban, hogy míg Mike mindezt a föderalizmus irodalmán belül, nem migrációelméleti megközelítésben tárgyalta, addig mi a specifikusság jelenségét a migráció közgazdaságtanába ágyazzuk be.

Furubotn \& Richter (2005) alapján Mike (2008; 2009; 2012) is kiemeli, hogy az emberek nem csak egy üzleti partnerrel, hanem a lakhelyük szerinti állammal való „kapcsolatban” is eszközölnek specifikus beruházásokat, ráadásul nem is elenyésző mértékben. Ezeket országspecifikus beruházásoknak nevezi, melyek jellemzője, hogy olyan eszközt hoznak létre, amely más országban már kevéssé értékesek. Álláspontja szerint valójában minden ember humántőkéjének egy jelentős része országspecifikus. Ilyen lehet a jogrend, a nemzeti kultúra, a helyi szokások vagy akár csak az olcsó boltok

\footnotetext{
${ }^{60}$ Megfelelő irányítási struktúra hiányában az érintettek esetleg nem lesznek ösztönözve a specifikus eszközbe történő beruházásra, amely egyébként költséghatékonyabb megoldást kínálna az adott tevékenység elvégzéséhez. Ezt a hold-up problémának nevezett jelenséget a következményeivel együtt már Williamson (1985) is leírta, egyfajta formalizálását Tirole (1986) végezte el, részletes tárgyalása és vizsgálata azonban leginkább Hart (2006; 2009) nevéhez kötődik. A probléma feloldása - a korlátozott racionalitás, a tranzakciós költségek és a specifikusság miatt - a piaci út helyett a vállalaton belüli megszervezéssel történhet.
} 
hollétének az ismerete, de ide sorolható maga a nyelvtudás is. Emellett az is fontos, hogy az ember mindennapi élete során - legyen szó magánéletről vagy üzletről - számos olyan kapcsolatot épít ki, amelybe specifikus beruházást eszközöl, s így azok az idioszinkrázia logikájának megfelelően helyhez kötik bizonyos mértékben. Ezen specifikus beruházások meghozatala azonban nem feltétlenül tudatos vagy akaratlagos. Amint Mike (2009,57. o.) megfogalmazza, ezek inkább csak az emberi „megismerés és együttmüködés” „melléktermékeinek” tekinthetők. ${ }^{61}$

Az, hogy az egyén humántőkéjének egy része - természetes életviteléből fakadóan - hely-, illetve országspecifikus, álláspontunk szerint a migrációs döntés meghozatalakor is fontos. Az adott országon belüli személyes és üzleti kapcsolatok kiépítésére, valamint a helyi jellemzők megismerésére fordított erőforrások ugyanis az elvándorlással elsüllyedt költségként jelentkeznének a migráns számára. Kiemelendő persze, hogy az elsüllyedt költségeknek a standard közgazdasági logika szerint nem kellene szerepet játszaniuk a racionális aktorok döntéseiben. A viselkedési közgazdaságtan empirikus eredményei azonban rendre azt mutatják, hogy ez nem így van. A gazdasági szereplők amellett, hogy a racionalitás posztulátumának ellentmondva figyelembe veszik az elsüllyedt költségeket a kalkulációjukban, hajlamosak szisztematikusan felül is becsülni a szerepüket, s ez gyakran egyfajta különös ragaszkodást is eredményez az érintett jószággal kapcsolatban. Ezt a jelenséget összefoglaló néven elsüllyedt költség hatásnak (sunk cost effect) vagy az elsüllyed költségek téveszméjének (sunk cost fallacy) nevezzük. Az elmélet fő állítása, hogy ha az ember egy jószágra pénzt költött, akkor azt ki is szeretné használni, még akkor is, ha az irracionális, hiszen erőforrásait aktuálisan jobban is tudná allokálni. Ennek oka pedig az, hogy ellenkező esetben (ti. ha a jószágról lemondana), mentális könyvelésében azt veszteségként kellene leírnia (Arkes \& Blumer, 1985; Hámori, 1998; Thaler, 1999; 2016).

A specifikus beruházások megléte, és az esetleges migráció révén történő „,hátra hagyásuk" nyomán jelentkező elsüllyedt költség hatás álláspontunk szerint a kivándorlással szemben is érdemi ellenösztönző lehet, föként egy heurisztikák, hüvelykujj-szabályok alapján döntő aktor számára. Utóbbi kognitív modelljében ugyanis ezek veszteségként jelenhetnek meg a kivándorlási alternatíva kifizetésében, akár felülreprezentált súllyal is. Így a döntés egyik fő szempontja is lehet, hogy az egyén milyen és mennyi országspecifikus beruházással rendelkezik. Modellünkben ezért azt

\footnotetext{
61 Amint arra Mike is hivatkozik, ez szintén összhangban van a Polanyi-féle (1962) személyes tudás
} jellemzőivel. 
várjuk, hogy a jelentősebb mennyiségü specifikus eszközzel (beleértve ebbe a humántőkét és az idioszinkrázia egyéb megjelenési formáit) rendelkező személyek kisebb hajlandóságot mutatnak az elvándorlásra. ${ }^{62}$

Az egyén humántőkéjének az emberi megismerés és együttmüködés révén specifikussá váló részének aránya általánosságban persze aligha mérhető, s ezen mértéknek a személyek közötti összehasonlíthatósága is igencsak kérdéses. Mindazonáltal néhány fontos - és nem utolsó sorban könnyebben mérhető - szempont kiemelhető e tárgykörben. Ilyen az egyén - már említett - idegennyelv-ismerete. Levonhatjuk ugyanis a következtetést, hogy az idegennyelve(ke)t beszélö emberek humántőkéje kevésbé országspecifikus, aminek eredményeként külföldön is nagyobb valószínüséggel találnak munkát, így részükről nagyobb elvándorlási hajlandóságot várhatunk. Ezáltal a nyelvtudás megléte modellünkben nem csak a tranzakciós költségek csökkentése révén, hanem a specifikusság itt ismertetett csatornáján keresztül is növelheti a migráció valószínűségét. A másik kiemelendő szempont az egyén kora. Természetes ugyanis, hogy az ember életkora előrehaladtával egyre több ilyen, megismeréshez és együttmüködéshez kapcsolódó specifikus beruházást eszközöl. Ez pedig azt implikálja, hogy az idősebb emberek várhatóan ceteris paribus kisebb elvándorlási hajlandóságot mutatnak. Mindez pedig összhangban van az irodalmi áttekintés 1.1.3. alfejezetében bemutatott humántőke elmélet hagyományos predikciójával, amely ugyanezt azzal magyarázza, hogy a migráció várható hasznai az idősebbek számára várhatóan csak rövidebb időhorizonton realizálódnak majd.

Noha az általános emberi kapcsolatok relációspecifikus vonásai már szóba kerültek, érdemes külön kitérni a személyes, családi kapcsolatok kötődésekre is. BenPorath (1980) alapján Williamson (2007) is utal a családi kapcsolatok idioszinkratikus jellegére, s intuitíve sem tagadható, hogy a család intézményének felépítése és fenntartása jelentős specifikus beruházásokat igényel az érintettektől. Ebből kifolyólag a családi kötelékben - akár egy háztartásban lakó partnerrel, akár házastárssal együtt - élő

\footnotetext{
${ }^{62}$ Megjegyzendő, hogy Mike (2009) kiindulópontja az volt, hogy az EU-s tagság növeli a specifikus beruházások külföldi hasznosíthatóságát, s ennek a változásnak a kivonulás-tiltakozás alternatívákra gyakorolt hatását dinamikus szemléletben vizsgálta. Eredményeinek többsége szerint az EU-s tagság növeli a kivonulás valószínüségét, $\mathrm{s}$ a maradási alternatíva csak hosszú távon, bizonyos feltételek mellett erösödhet meg. Mindez, azonban kívül esik jelen disszertáció fókuszán, hiszen itt statikus szemléletben vizsgálódva azt a hipotézist fogalmazzuk meg, hogy azok, akik rendelkeznek specifikus beruházásokkal, ceteris paribusis kisebb valószínüséggel vándorolnak ki, mint akik nem. Ráadásul azok a specifikus beruházás-típusok, amelyeket a továbbiakban emelünk ki, s az empirikus elemzésbe is bevonunk, álláspontunk szerint nem tartoznak a Mike által említettek közé, tehát külföldi hasznosíthatóságuk nem nő az EU-s intézményi környezet ellenére sem.
} 
személyektől, illetve a gyermekesektől a relációspecifikusság partnerhez kötő tulajdonsága alapján kisebb elvándorlási hajlandóságot várhatunk, mint az egyedülállóktól és a gyermektelenektöl. ${ }^{63}$

A specifikusság fenti tárgyalásából az is kitünik, hogy a téma kapcsán érdemes az emberek munkaviszonyáról is szót ejteni. Az már az irodalmi áttekintésben is kirajzolódott, hogy a munkahellyel rendelkező személyek ceteris paribus kisebb elvándorlási kedvet mutatnak, mint a munkanélküliek. Ez legegyszerübben a keresetekkel magyarázható: előbbieknek értelemszerủen pozitív összegű jövedelemmel rendelkeznek, amely nem csak a nullánál, de nagy valószínűséggel az esetleges munkanélküli segélynél is magasabb. Így a kivándorlásból származó várható nettó haszon lényegesen nagyobb lehet a munkaviszonnyal nem rendelkezők számára. A specifikusság jelensége azonban ezen empirikus tény magyarázatához is további adalékkal szolgálhat. Mint arra már utaltunk, Williamson (2007), és Mike (2009) is hivatkozik Polanyi (1962) gondolataira a specifikus humántőke tárgyalása kapcsán: a munkavégzés során az ember olyan személyes tudásra, képességekre és szakértelemre tesz szert, amely gyakran nem vihető át más munkakörbe vagy munkaadóhoz. Az ezek elsajátítására fordított erőforrások az elvándorlás esetén ugyancsak elsüllyedt költségként jelentkezhetnek. Ez pedig újabb magyarázattal szolgálhat arra, hogy az ilyen, a fennálló munkaviszonyhoz vagy munkakörhöz kötő személyes tudással aktuálisan nem rendelkező munkanélküliek ceteris paribus miért lehetnek hajlamosabbak a migrációra. ${ }^{64}$

Az egyén lakóhelyének típusa, s ennek migrációs hajlandóságra gyakorolt hatása ugyancsak összefüggésben állhat a specifikusság jelenségével. Fél-egy évszázaddal ezelőtt még azt láttuk, hogy jellemzően a vidéki környezetben élők vándoroltak országon belül a nagyvárosokba, ami elsősorban a technológiai fejlődésből adódó munkaerőpiaci változásoknak volt köszönhető. A nemzetközi migrációban azonban napjainkban azt tapasztaljuk, hogy a nagyvárosi emberek sokkal hajlamosabbak az elvándorlásra, mint a kisebb településeken, illetve vidéki környezetben élő polgártársaik. Ezt a szociológiai

\footnotetext{
${ }^{63}$ Ezen hipotézis természetesen akkor lehet megalapozott, ha azt feltételezzük, hogy az egyén egyedül, családtagjait hátrahagyva vándorolna külföldre. Amennyiben a család együtt migrál, úgy a specifikus beruházások ezen hatása nem jelentkezik (ellenben a mobilitási, valamint a tranzakciós költségek érdemben nöhetnek).

64 Természetesen nem kívánjuk azt állítani, hogy a specifikusságon alapuló magyarázatunk hatásmechanizmusa bármilyen szempontból is „erösebb” lenne a standard érvelésénél. E hatások „megmérése” és a kérdés eldöntése ugyanis jóval túlmutatna jelen disszertáció keretein. Ugyanakkor Williamsonhoz (1985) hasonlóan - aki némi túlzással a legtöbb gazdasági jelenséget a specifikusságra vezette vissza - fontosnak tartjuk kiemelni, hogy az idioszinkrázia jelensége számtalan helyen megjelenik a társadalmi és gazdasági együttélésben, s egy adott cselekvés során több csatornán keresztül is befolyásolhatja döntéseinket.
} 
ihletésü irodalmak leginkább a beágyazottság fogalmával tudják magyarázni. Az urbánus életvitelt gyakran a személytelenség, az individualizmus jellemzi, míg vidéken a falvak és kisvárosok mindennapjaiban a személyes kapcsolatok sokkal dominánsabbak, s a kollektivista szemlélet is jobban megfigyelhető. Utóbbiak életvitele tehát - a granovetteri (1985) értelemben - beágyazottabb a helyi közösségi életbe. Mindez a specifikusság fogalmával is összecseng. ${ }^{65}$ A beágyazottsághoz, a helyben szükséges kapcsolatok kialakításához ugyanis a fentiekben tárgyaltak szerinti specifikus beruházások megtételére van szükség. Így, arra következtetve, hogy a vidéken élők ceteris paribus több - a beágyazottsághoz szükséges - specifikus beruházást eszközölnek, részükről az elvándorlási hajlandóság is kisebb lehet, mint a nagyvárosiak esetében.

Ezeken túlmenően az egyén további közvetlen specifikus beruházásokat is eszközölhet. Ennek talán legkézenfekvőbb példája lehet az, ha saját ingatlannal rendelkezik, amelynek más helyre, más országba költözés esetén az egyén szempontjából vett - használatból eredő - értéke értelemszerüen kisebb. Természetesen a tulajdonolt ingatlan értékesíthető lehet, ám az mindenképp tranzakciós költséggel jár, ami az aktuális ingatlanpiaci viszonyok függvényében akár igen jelentős is lehet. ${ }^{66}$ Ezáltal az ingatlanra fordított ár ténylegesen nem válik elsüllyedt költséggé (kivéve persze, ha a piaci viszonyok miatt a bekerülési költségnél alacsonyabb áron kell megválnia töle), de az ingatlan használati funkcióját már nem tölti be a kivándorló számára. Mindez azonban épp elegendő lehet egy korlátozottan racionális egyén számára ahhoz, hogy ingatlantulajdonosként kisebb valószínüséggel válassza a migráció alternatíváját.

Összességében tehát amellett érvelünk, hogy a specifikusság jelensége és a(z ország)specifikus beruházások meghozatala - akár akaratlagosan, akár akaratlanul végigkíséri az emberi életet, $\mathrm{s}$ ezáltal az elvándorlási hajlandóságot is befolyásolja. Az idioszinkrázia, ahogyan a gazdasági életben egy üzleti partnerrel, úgy a migrációban egy adott hellyel vagy országgal szemben alakít ki erős kötődést. A specifikusság fogalma ezáltal egységes közgazdaság-tudományi keretet és magyarázatot tud adni több olyan megfigyelésre, amelyekre eddig a migrációs irodalom csak egymástól elszeparált válaszokkal szolgált.

\footnotetext{
${ }^{65}$ Mint arra az irodalmi áttekintés során már utaltunk, ez a gondolatiság Haugnál is megjelenik, amikor a migrációs hálózatok kapcsán a társadalmi tőke helyspecifikus részét és a beágyazottság kérdését tárgya.

${ }^{66} \mathrm{Az}$ értékesítésnek alternatívája lehet még a bérbe adás is, ennek az irányítása azonban alighanem még több tranzakciós költséggel jár, illetve azzal, hogy a beruházás egy része - legalábbis időlegesen - elsüllyedt költségként „,bent ragad” az ingatlanba.
} 


\subsubsection{Döntési szempontok: lelki költségek, altruizmus, hűség}

Amint azt irodalmi áttekintésünk 1.1.3. alfejezetében bemutattuk, a migrációs irodalom rendre megemlíti, hogy a kivándorlási döntésben bizonyos lelki költségek is szerepet játszanak, ennél tovább azonban már nem lép. E tényező részletes tárgyalását az elméletek általában mellőzik, s ennek folyományaként a formális modellekben sem szerepel. Az alábbiakban ebben kívánunk elöre lépni. Jelen alfejezetben bemutatjuk, hogy modellünkben a lelki költségek milyen formában jelentkeznek, s hogyan képesek befolyásolni a migrációs döntést. ${ }^{67}$

A lelki költségeknek az irodalomban használt formában való megjelenését a migrációs döntésben mi is fontosnak véljük. Az, hogy az egyénnek pszichológiai „fájdalommal” jár korábbi társas kapcsolatainak megszakítása, s ez csökkenti a hasznosságát, aligha tagadható. ${ }^{68}$ Emellett azonban álláspontunk szerint létezik egy másik - az altruizmus révén jelentkezö - csatorna, amelyen keresztül lelki tényezök csatornázódnak be a döntésbe.

Noha disszertációnk a módszertani individualizmus talaján áll, hangsúlyozzuk, hogy az ember társas lény. Döntéseit nem a külvilágtól függetlenül, rideg számítások alapján hozza, hanem a társas kapcsolatokban megjelenő érzelmek is befolyásolják. Ahogyan azt a viselkedési előfeltevésekről szóló 2.1. alfejezetben jeleztük, modellünkben teret engedünk az altruizmus megjelenésének, amelyet az interdependens hasznossági függvények segítségével építünk be.

Kiindulópontunk, hogy az ember nem kizárólag semleges érzelemmel viszonyulhat másokhoz, hanem jóindulattal, pozitív beállitódással is bírhat bizonyos személyek irányába (Hámori, 1998). Ez abban nyilvánulhat meg, hogy törődik velük, saját döntései során az ő jólétükre gyakorolt hatást is figyelembe veszi. Egyeseknél ez a kör igen szük lehet, amely például csak a családra terjed ki, míg mások akár tágabb közösségük, így például országuk társadalmának a jólétére is tekintettel lehetnek. Formálisan - mint azt a 2.3.6. alfejezetben felírjuk majd - mindez úgy jelentkezik, hogy az aktor jóléti függvényébe meghatározott súllyal az érintettek jóléte is független

\footnotetext{
${ }^{67}$ A hüséggel kapcsolatos gondolatok megfogalmazásakor támaszkodtunk korábbi munkánkra (Golovics, 2016b). Továbbá az itt megfogalmazott következtetések egy része, illetve azok szerkesztett változata megjelent: Golovics (2019b).

${ }^{68}$ Fontosnak tartjuk kiemelni, hogy itt szigorúan csak az érzelmi alapú jólét-változásokra gondolunk. Több olyan tényezőt ugyanis, amelyeket a korábbi irodalmak felületesen a lelki költségek közé soroltak volna, a specifikus beruházások tárgyalásánál már „lekötöttünk”. Példaként említhető, hogy a korábbi életvitel feladásával járó „fájdalom” a specifikusság nyomán fellépő elsüllyedt költség hatás miatt jelentkezik, így itt csak ezen felüli jólétváltozásokat vesszük figyelembe.
} 
változóként kerül beemelésre. Az ezen körbe tartozókat, tehát akiknek jólétével az egyén saját hasznossági függvényében is számol, az aktor hozzátartozóiként definiáljuk. ${ }^{69} \mathrm{~A}$ hozzátartozók köre személyenként és időben is változhat, s a különböző személyekkel való „törődés” mértéke is eltérő lehet, de adott időpillanatban mindezt exogén adottságnak tekintjük minden egyénnél.

Ez az altruista attitüd álláspontunk szerint az elvándorlási kedv alakításában is fontos szerepet játszik. Az aktor kivándorlása esetén ugyanis hozzátartozóinak jólétében is változás állhat be, amely az interdependens hasznossági függvényen keresztül azonos előjellel visszahat az előbbi jólétére is. Elvándorlás esetén így a hozzátartozók lelki veszteségei, a megnehezedő kommunikációból adódó többletköltségei vagy akár a költségvetési externália ${ }^{70}$ nyomán rájuk nehezedő fiskális teher a migráns számára is jelentkezik. Ez pedig, mivel csökkenti a migrációból származó nettó hasznot, súlyos ellenösztönzőként szolgálhat a kivándorlással szemben. Előfordulhat akár az is, hogy az egyénnek szigorúan vett önérdeke alapján racionális döntés lenne a kivándorlás, de mivel figyelembe veszi, hogy ezzel rontana hozzátartozói jólétén, mégis a maradás mellett dönt.

Korábbi tanulmányunkban az ilyen altruista kapcsolatokat hüségként definiáltuk (Golovics, 2016b), s itt is kezelhetjük úgy a jelenséget, hogy az altruista kapcsolat egyfajta hüséget keletkeztet bizonyos személyek, csoportok vagy akár egy teljes nemzetközösség irányába. A kifejezés használatának alapját az adta, hogy ha az egyén saját hasznossági függvényében érzi a kivándorlásával hozzátartozóinak okozott veszteséget, az hatásában lényegében azonos a Hirschman (1995) kivonulás-tiltakozáshűség modelljében megjelenő ,,kivonulási adóval”. ${ }^{71}$ Elméletét Hirschman elsősorban az üzleti életre, így például egy egyén (akár fogyasztó, akár munkavállaló) és egy vállalat kapcsolatára vonatkoztatva fogalmazta meg, melyben előbbi elégedetlenség esetén a kivonulás és a tiltakozás alternatívái közül választhat. A két lehetőség között a hűség

\footnotetext{
${ }^{69}$ Az általunk definiált hozzátartozó kifejezés így eltér a hétköznapi szóhasználattól. A hozzátartozók fogalmába így beletartozhatnak olyan személyek is, akikkel az egyén akár soha nem is találkozott személyesen, de törődik a sorsukkal, jólétükkel. A választóvonalat e meghatározás szerint nem a személyes közelség adja, hanem az, hogy az adott személy jólétét valamekkora súllyal beemeli-e az aktor a saját hasznossági függvényébe.

${ }^{70}$ Költségvetési externália akkor jelentkezik, ha az egyén egy adott kormányzat fennhatósága alól egy másiké alá költözik: ezzel ugyanis előbbinél csökkenti, utóbbinál pedig növeli az adóalapot. Ez a kedvezőtlenül érintett kormányzat számára azzal a kellemetlenséggel jár, hogy a kisebb adóbevétel miatt csökkentenie kell a közszolgáltatási szintet, vagy a változatlan minőség fenntartásához többletterheket kell rónia a társadalom megmaradt részére (Szalai 2002; Wildasin 1989). Ez a hatás egy szereplő kivándorlása esetén természetesen marginális. Amennyiben azonban a migráció tömegessé válik, úgy a negatív hatás jelentős méreteket ölthet.

71 A gondolati párhuzamot Simon $(1990 ; 1993)$ azon érvelése is az is erősíti, mely szerint a társadalom „megadóztatja” a docilis egyéneket azáltal, hogy altruista magatartásra vezeti őket.
} 
teremt egyensúlyt, mégpedig azáltal, hogy a hüséges személy a kivonulás után sem válna közömbössé korábbi partnere sorsát illetően. Ha pedig tudja, hogy kivonulásával még inkább hozzájárul utóbbi helyzetének hanyatlásához, akkor ezt egyfajta internalizált „hűtlenségi” vagy „kivonulási adóként” éli meg. Ez pedig kellő nagyság esetén maradásra - illetve a maradás melletti tiltakozásra - is bírhatja.

Hirshcman (1978) maga is megfogalmazta, hogy ilyen jellegü hüség az állampolgár és az állam viszonyában is megjelenhet. Ennek feltételeként olyan közjószág-jellegü tényezőket jelölt meg, mint az ország magas presztízse, távol maradása a nemzetközi konfliktusoktól, a társadalmi igazságosság megnyilvánulása ${ }^{72}$, illetve az emberi- és a demokratikus szabadságjogok garantálása. Utóbbiak összecsengenek azon jellemzőkkel, amelyeket a 2.2. alfejezetben a befogadó intézményrendszer kapcsán fogalmaztunk meg. Ez pedig azt az implikációt hordozhatja magában, hogy - legalábbis a hirschmani logika alapján - a befogadó intézményrendszer léte azáltal is ellenösztönzőként szolgálhat a kivándorlásra, hogy hüséget keletkeztet az állampolgárban országa iránt.

Az állam iránti hüség és az elvándorlás kapcsolatát Hirschman nyomán többen is tárgyalták, noha a formális modellalkotásig, illetve a megfogalmazott állítások valamely migrációs elméletbe történő integrálásig egyikük sem jutott el. Ruget \& Usmanalieva (2008) csak általánosságban beszélt a hüség szerepéről, Schewel (2015), illetve Carling \& Schewel (2018) pedig a nem gazdasági jellegü visszatartó tényezők között említik munkáikban. Johnston (2011) és Burgess (2012) kvalitatív eszközökkel vizsgálják az elvándorlók - például a hazautalások révén jelentkező - befolyását a küldő ország politikai rendszerére. Hoffman (2010) pedig szintén ilyen kontextusban az elmélet empirikus alkalmazhatósága mellett annak továbbgondolási lehetőségeit fejtegette.

Az előbbiek mellett Mike (2008; 2009; 2012) már hivatkozott munkáit említhetjük, amelyek a hűség megjelenését a specifikus beruházásokkal hozzák összefüggésbe. Ennek indokaként utóbbiak könnyebb megfigyelhetőségét és a közgazdasági elemzésbe történő egyszerübb bevonhatóságát jelöli meg. Noha a két tényező közé Mike sem tesz egyenlőségjelet, állítása szerint hatásukban azonosak, ráadásul a specifikus beruházások a hűség forrásaként szolgálhatnak.

\footnotetext{
72 Az igazságosság kapcsán Hirschman (1978, 105. o.) azt írja, hogy „az egyének kellemesebbnek találhatják egy olyan társadalomban élni, ahol a jövedelmek eloszlása viszonylag egalitárius". Ez összhangban van a migráció új közgazdaságtanának azon, az irodalmi áttekintésünk 1.1.6. alfejezetében ismertetett érvével, mely szerint a jelentős országon belüli jövedelmi egyenlötlenség fontos taszító tényező lehet a potenciális migránsok számára.
} 
Noha disszertációnkban mind a specifikus beruházások, mind a hüség szerepét tárgyaljuk, Mikével ellentétben e két fogalmat szeparáltan kezeljük. A megközelítésmódbeli különbség oka, hogy míg Mike (2009) a hüség megjelenését a specifikus beruházások megtételére vezette vissza ${ }^{73}$, a disszertációnkban szereplő hűségtényező az altruizmuson alapszik. Mike a hüség racionális vonását akarta megragadni, az általunk használt altruizmust azonban a racionalitás korlátozottsága, s az egyén társadalom általi befolyásolhatósága indokolja. Így modellünk hüségtényezője is egyfajta kötődést eredményez, de az érzelmi alapú, s a hasznosságok interdependenciájából ered, nem az egyénnek a specifikus eszközbe fektetett beruházások elsüllyedt költséggé válásától való félelméből. Álláspontunk szerint a kötődés megteremtés révén mindkét tényező fontos befolyásolója a migrációs döntés alakulásának, ám jellegükből fakadóan külön kezelendőek.

Mindezt úgy foglalhatjuk össze, hogy bizonyos személyek altruista attitüddel bírnak, s ez kihatással van az elvándorlási hajlandóságukra is. Az altruizmus ugyanis összekapcsolja a potenciális migráns és hozzátartozói jólétét, amely egyfajta hűség-alapú kapcsolatot hoz létre közöttük. Érvelésünk szerint ezen altruizmuson alapulú kötődések, illetve hüség megléte ellenösztönzője lehet a kivándorlásnak.

\subsection{Formális modell}

A megelőző fejezetekben verbálisan kifejtett szempontok alapján elméleti modellünket formálisan foglaljuk össze. ${ }^{74}$ Ehhez tekintsük a 2.1. alfejezetben lefektetett viselkedési jellemzőkkel bíró egyént, aki a migráció gondolatának felmerülése és a keresési folyamat lefolytatása után az elvándorlás vagy maradás alternatívái közül választ. A döntést két variánsra szükítjük, ami egyszerüsítés ugyan, de mind a modell logikája, mind a gyakorlati szempontjából indokolható. Ez az irodalomban is szokásosnak tekinthetö. Mint Borjas (1989, 461. o.) leszögezi, a migrációs döntés modellezéséhez elegendő a két országos eset, ugyanis ,,a több országra történő általánosítás csak a modell technikai aspektusait komplikálja anélkül, hogy a kiválasztás kulcsfontosságú karakterisztikumait megváltoztatná”. Ráadásul jelen disszertáció elméleti modelljéből is az következik, hogy a keresés lefolytatása után az aktor az általa legjobbnak vélt

\footnotetext{
73 A pontosság kedvéért megjegyzendő, hogy a hüség további lehetséges forrásai között Mike (2009) is említ olyan tényezőket, mint az érzelmek, a bizalom, az erkölcsösség, az identitás, illetve a preferenciák állandósága. Mivel azonban munkájában a hűség racionális mozzanatait kívánja megragadni, ezeket csak érintőlegesen tárgyalja, s következtetéseit nem erre, hanem a „specifikus beruházások mint a hüség oka” gondolatmenetre füzi fel.

${ }^{74}$ A formalizálás során használt jelölésekhez kiindulópontot jelentett Huber \& Nowotny (2013) munkája, de a későbbiekben ettől saját modellünk specifikumai tükrében jelentősen eltértünk.
} 
alternatívával hasonlítsa össze az otthonmaradás lehetőségét. Ebben a kontextusban tehát $k$ egyén dönt arról, hogy $i$ származási (vagy küldő) országából kivándoroljon-e $j$ fogadó (vagy cél-) országba. A következőkben $i$ és $j$ indexek rendre ezen országokra, $k$ index pedig az egyénre utal.

Az egyén hasznossági függvényét additív szeparábilisnek feltételezve, az otthonmaradási alternatíva hasznosságát, $U_{i}^{k}$-t az (1) kifejezés adja meg:

$$
U_{i}^{k}=Y_{i}^{k}+G_{i}^{k}
$$

ahol $Y_{i}^{k}$ a munkával szerezhető jövedelmet, $G_{i}^{k}$ pedig az 1.1.3. alfejezetben leírtak szerinti, az egyén számára érzékelt nettó közszolgáltatási szintet jelöli. Utóbbi tehát mindazon pénzbeli és nem pénzbeli juttatások és terhek nettósított értékéből áll össze, amelyekkel az ország kormánya támogatja, illetve sújtja lakosait. Szemben azonban a különböző formulákat használó - tökéletes racionalitást feltételező irodalmak szokásos megközelítéseivel (vö. például DaVanzo, 1981a; Huber \& Nowotny, 2013; Massey és mtsai., 1993) nem feltételezzük, hogy ezen tényezők a jövedelemáramlások tökéletesen kalkulált várható értékeinek diszkontált jelenértékei lennének. Ezek kiszámítására modellünk kognitív korlátokkal rendelkező egyéne ugyanis nem képes. Kvalitásai arra kiterjednek ugyan, hogy különbséget tegyen az egyszeri és rendszeres tételek között, illetve figyelembe vegye, hogy utóbbiakkal életkorának tükrében hosszabb vagy rövidebb ideig számolhat, de a komplex matematikai számítások elvégzésére már nem. Ezért $Y_{i}^{k}$ és $G_{i}^{k}$ változók a megnevezett tényezőknek a $k$ által belátott élethosszra csak hozzávetőleges, szubjektíven becsült értékeit jelölik. Ennek megfelelően maguk az $U^{k}$ hasznossági függvények is ilyen időtávra vonatkoznak, s a következőkben ismertetendő módon szerepelnek benne egyszeri, illetve a további életszakasz során rendszeresen jelentkező tételek.

A várható munkajövedelem nagyságát az előző alfejezetek alapján a (2) kifejezés adja meg:

$$
Y_{i}^{k}=Y_{i}^{k}\left(\chi_{\boldsymbol{i}} \boldsymbol{d}_{\boldsymbol{k}} ; \theta_{i} S P_{k} ; L M_{i} ; I N_{i}^{k}\right),
$$

ahol $\boldsymbol{d}_{\boldsymbol{k}}$ az aktor egyedi jellemzőinek vektora. Ezek többek között humántőkéjének minőségét, s ezáltal munkaerejének a munkaadók szemszögéből vett értékét befolyásolják, így itt szerepel például kora, iskolázottsága, munkatapasztalata vagy éppen a neme. $\chi_{\boldsymbol{i}}$ szintén egy vektor, amely azt jelöli, hogy $k$-nak a $\boldsymbol{d}_{\boldsymbol{k}}$-ban megjelenített jellemzőit $i$ ország munkaerőpiaca hogyan értékeli. A $\chi$ vektorban szereplő súlyok országonként eltérők lehetnek, de a magasabb értékek nagyobb jövedelmet 
eredményeznek, illetve általánosságban feltételezzük, hogy a jobb minőségű humántőkét minden állam munkaerőpiaca magasabbra értékeli, tehát $Y^{k} \boldsymbol{d}$ és $\chi$ növekvő függvénye. ${ }^{75}$ Az $S P_{k}$ az egyén által megtett specifikus beruházásokra utal: ezek közül az egyén humántőkéjének specifikus része (például az adott munkakörben szerzett tapasztalat vagy az országspecifikus tudás), illetve az emberi kapcsolatokba fektetett erőforrások emelendők ki, hiszen e tényezők a munkajövedelem meghatározásában is fontos szerepet játszanak, méghozzá pozitív értelemben. Ennek megfelelöen $\partial Y^{k}(.) / \partial S P_{k}>0$. A változó együtthatójaként szereplő $\theta_{i}$ egy súly, azt fejezi ki, hogy ezek a specifikus beruházások mennyiben az $i$ országra, illetve az ottani munkájára vonatkozóan specifikusak. Más szóval a specifikus beruházások $i$-beli hasznosíthatóságát jelzi. $L M_{i}$ a küldő ország munkaerőpiaci viszonyaira utal, amelyek - például a bérszínvonal vagy épp a munkaerőpiac feszességét jelző munkanélküliség révén - szintén meghatározók az egyén jövedelme szempontjából. Kedvezőbb munkaerőpiaci környezet mellett $k$ is magasabb bérre számíthat, azaz $\partial Y_{i}(.) / \partial L M_{i}>0$. A 2.2. alfejezetben lefektetettek alapján ugyanez az ország intézményrendszeréről is elmondható. Ha az intézmények jól müködnek, a jövő is kiszámíthatóbb, s ha az egyén bízik az intézményekben, akkor jövőbeli várható jövedelmét is biztosabbnak érzi. Mindez azt indokolja, hogy modellünkben $I N_{i}^{k}$-t, amely $k$-nak az $i$ ország intézményrendszerébe vetett bizalmát jelöli, a származási országban várható munkajövedelem befolyásoló tényezői között szerepeltessük, feltételezve, hogy $\partial Y_{i}^{k}(.) / \partial I N_{i}^{k}>0$.

Az otthonmaradási alternatíva hasznosságának másik összetevője a nettó közszolgáltatási szint $k$ számára jelentkező nagysága, amely nagyságát a (3) kifjezés adja meg:

$$
G_{i}^{k}=G_{i}^{k}\left(\boldsymbol{\omega}_{i} \boldsymbol{d}_{\boldsymbol{k}} ; I N_{i}^{k}\right),
$$

ahol a munkajövedelemmel analóg módon $\boldsymbol{d}_{\boldsymbol{k}}$ vektor az aktor egyedi jellemzőire utal, $\boldsymbol{\omega}_{\boldsymbol{i}}$ vektor pedig azt adja meg, hogy $i$ ország kormányzata ezen jellemzővel rendelkező egyéneket miként szubvencionálja, illetve terheli. $I N_{i}^{k}$ azért jelenik meg itt is, mert az intézményekbe vetett bizalom mértéke befolyásolja, hogy a nettó közszolgáltatási szint mértékét az egyén mennyire érzi kiszámíthatónak. Itt a bérekhez hasonlóan feltételezzük, hogy $\partial G^{k}(.) / \partial \boldsymbol{d}_{\boldsymbol{k}}>0$ és $\partial G_{i}^{k}(.) / \partial I N_{i}^{k}>0$.

${ }^{75}$ Ez $\boldsymbol{d}$-nek olyan kalibrációját feltételezi, amely mellett a vektorban szereplő magasabb értékek jobb minőségü humántőkére utalnak. 
Így a (2) és (3) kifejezéseket az (1) kifejezésbe behelyettesítve az otthonmaradás hasznát a (4) kifejezés adja meg:

$$
U_{i}^{k}=Y_{i}^{k}\left(\chi_{i} \boldsymbol{d}_{\boldsymbol{k}} ; \theta_{i} S P_{k} ; L M_{i} ; I N_{i}^{k}\right)+G_{i}^{k}\left(\boldsymbol{\omega}_{\boldsymbol{i}} \boldsymbol{d}_{\boldsymbol{k}} ; I N_{i}^{k}\right) .
$$

Ennek alternatíváját, a kivándorlás hasznosságát az (5) kifejezés mutatja meg:

$$
U_{j}^{k}=Y_{j}^{k}+G_{j}^{k}-C_{m}^{k}-C_{s}^{k}-C_{p}^{k},
$$

ahol, $Y_{j}^{k}$ és $G_{j}^{k}$ a munkajövedelem és a nettó közszolgáltatási szint $j$-beli megfelelői, $C_{m}^{k}$ pedig a 2.3.3. alfejezetben leírtaknak megfelelően, egyszeri tételként, az egyén számára jelentkező mobilitási költségekre utal. A 2.3.4. alfejezetben leírtak alapján indokoltnak látjuk külön, valódi erőforrás-költségként szerepeltetni a specifikus beruházások nyomán jelentkező elsüllyedt költségeket, amelyet $C_{s}^{k}$ jelöl. Mint azt korábban tárgyaltuk, egy tökéletesen racionális egyén kalkulációjában ezek - pontosan az elsüllyedt jellegük miatt - nem szerepelnének, ugyanakkor a viselkedési közgazdaságtan eredményei alapján úgy véljük, ezáltal valószerübb képet kaphatunk a migrációs döntések tényleges természetéről. Ezen elsüllyedt költségek mértéke természetesen maguknak a specifikus beruházásoknak a mennyiségétől függ, így modellünkben $C_{s}^{k}=C_{s}^{k}\left(S P_{k}\right)$ úgy, hogy $\partial C_{s}^{k} / \partial S P_{k}>0$. Elsősorban egyszeri tételként gondolhatunk rájuk, azonban az egyén veszteségérzete hosszabb időn keresztül is jelentkezhet, amely a modellben úgy manifesztálódhat, hogy $C_{s}^{k}$ mértéke még az ésszerüen vártnál is nagyobb lehet. A 2.3.5. alfejezetben leírtak alapján a lelki költségekkel is számolnunk kell, amelyeket modellünkben a $C_{p}^{k}$ változó jelenít meg. Mint azt kifejtettük, disszertációnk lelki költségei az egyén altruista attitüdjén keresztül jelentkeznek, méghozzá azáltal, hogy az aktor $T U^{k}$ val jelölt teljes hasznossága nem kizárólag saját, hanem hozzátartozói jólététől is függ. Ezt a (6) kifejezésben felírt módon formalizálhatjuk:

$$
T U^{k}=T U^{k}\left(U^{k} ; \gamma_{x_{1}} U^{x_{1}} ; \gamma_{x_{2}} U^{x_{2}}, \ldots, \gamma_{x_{n}} U^{x_{n}}\right),
$$

ahol $U$ a hasznossági szintekre, $x_{1}, x_{2}, \ldots, x_{n}$ indexek $k$ hozzátartozóira, a $\gamma$ súlyok a velük való kapcsolatok erősségére utalnak, $\mathrm{s} \partial T U^{k} / \partial U^{x}>0$ minden $x=x_{1}, x_{2}, \ldots, x_{n}$ esetén. $^{76}$ Ezen interdependens hasznossági függvény tükrében a kivándorlási alternatívában szereplő lelki költségeket a (7) kifejezés szerint definiálhatjuk:

$$
C_{p} \equiv \gamma_{x_{1}} \Delta U^{x_{1}}+\gamma_{x_{2}} \Delta U^{x_{2}}+\cdots+\gamma_{x_{n}} U^{x_{n}}=\sum_{x=x_{1}}^{n} \gamma_{x} \Delta U^{x},
$$

\footnotetext{
${ }^{76}$ Mivel az altruizmus jóindulatra utal, ezért a kapcsolat jellegéből az következne, hogy $\gamma>0$ minden $x_{1}, x_{2}, \ldots, x_{n}$ esetén. Elméleti szinten azonban meghagyhatjuk a lehetőséget a rosszindulat, tehát a $\gamma<0$ esetre is, amely úgy lenne interpretálható, hogy az egyénnek hasznosságnövekménye származik a vele rosszindulatú kapcsolatban álló személyek veszteségeiből. A rosszindulatról bővebben lásd Hámori (1998).
} 
ahol $\Delta U$-k a hozzátartozóknak $k$ migrációja nyomán jelentkező hasznosságváltozásokat jelölik. Így $C_{p}$ magába foglalja az összes ilyen altruista kapcsolatban származó jólétváltozás $k$-ra való visszahatását. Tekintve, hogy az elvándorlás nem csak az azt követő időszakban okozhat veszteséget a hozzátartozóknak, az ennek nyomán jelentkező lelki költségek sem egyszeri tételként értelmezhetök modellünkben, hanem élethosszig éreztethetik hatásukat $k$ számára. Amennyiben az egyén senki iránt nem bír ilyen altruista kötődéssel, azaz $\gamma_{x}=0$ minden $x$-re, úgy effajta lelki költségei nem jelentkeznek, tehát $C_{p}^{k}=0 .{ }^{77}$

Hangsúlyozandó, a fent leírtak azt is jelentik, hogy a $C_{p}^{k}$-ban manifesztálódó lelki költségek csak akkor „élesednek”, ha $k$ elvándorlásából fakadóan változik otthonmaradó hozzátartozóinak a jóléte. Nem jelentkezik tehát hatás akkor, ha a hozzátartozók (például a családja) az egyénnel együtt migrálnak. Sőt, modellünk azt az esetet is tartalmazza, amikor a kivándorlás célja pontosan az, hogy a hazautalások révén $k$ segíteni tudja otthonmaradó hozzátartozóit. Ekkor utóbbiak jóléte nő, amelyet $k$ is pozitív irányú hasznosságváltozásként él meg, ami növeli a kivándorlási alternatíva vonzóságát. Az effajta magatartás pedig, ugyancsak altruista motivációkkal bír, így egyezik a modellünkben lefektetett alapvetésekkel.

A fogadó országbeli munkával szerezhető jövedelem nagyságát a (8) kifejezésben szereplő tételek befolyásolják:

$$
Y_{j}^{k}=Y_{j}^{k}\left(\chi_{j} \boldsymbol{d}_{\boldsymbol{k}} ; \theta_{j} S P_{k} ; L M_{j} ; \operatorname{Tr} C_{k}\right)
$$

A küldő országbeli jövedelemmel analóg módon $\chi_{\boldsymbol{j}}$ és $\boldsymbol{d}_{\boldsymbol{k}}$ vektorok adják meg, hogy az aktor milyen egyedi jellemzőkkel rendelkezik, s $j$ munkaerőpiaca ezeket miként értékeli. $S P_{k}$, illetve $\theta_{j}$ továbbra is az egyén által megtett specifikus beruházásokra, valamint ezek hasznosíthatóságára utal. Tekintve azonban, hogy ezek az adott kapcsolaton vagy felhasználáson kívülre kerülve definíciószerúen veszítenek az értékükből, $\theta_{j}<\theta_{i}$ minden esetben. A teljesen ország- vagy kapcsolatspecifikus beruházások esetén, amelyek külföldön egyáltalán nem hasznosíthatók az egyén számára, akár a $\theta_{j}=0$ egyenlőség is fennállhat. Az $L M_{j}$ tényező itt is a helyi munkaerőpiac jellemzőit ragadja meg, az intézményekbe vetett bizalom mértékére utaló változó

\footnotetext{
77 Szólhatnak érvek amellett is, hogy a lelki költségek - esetleg valamilyen új paraméterrel szorozva szerepeljenek az (1) és (4) maradási alternatívákban is, ettől azonban eltekintünk. Ennek értelmezése a következő: a kivonulás csökkentheti az altruista egyén hasznosságát, amennyiben azonban marad, az lelki szempontból nem jelent számára többlethasznosságot.
} 
ugyanakkor nem szerepel a (8) kifejezésben. Ennek oka, hogy - mint azt már jeleztük a bizalom egy tapasztalati úton megszerezhető érzet, így ilyennel a fogadó ország intézményeire vonatkozóan az aktor nem rendelkezhet. ${ }^{78} \mathrm{~A} \operatorname{Tr} C_{k}$ azon tranzakciós költségek mértékét jelöli, amellyel az egyénnek - a 2.3.2. és 2.3.3. alfejezetekben bemutatottak szerint - a keresés és a migráció kapcsán egyszeri tételként számolnia kell. Ezen tranzakciós költségek mértékét a korábban leírtaknak megfelelően olyan tényezők befolyásolhatják, mint például az egyén idegennyelv-ismerete, az, hogy rendelkezik-e migrációs hálózattal, hogy milyen technológiákhoz fér hozzá, vagy közvetetten akár az, hogy milyen típusú településen lakik. Ennek megfelelően $\partial Y_{j}^{k} / \partial \operatorname{Tr} C_{k}<0$, a többi tényező pedig az otthonmaradási alternatívában leírtaknak megfelelő irányban befolyásolja $Y_{j}^{k}$ nagyságát.

Az (5) kifejezésben szereplő nettó közszolgáltatási szint mértékét a (9) kifejezés adja meg. Ebben - az előző bekezdésben ismertetett logikát alkalmazva - szintén nem szerepel semmilyen intézményi bizalomra utaló tényező. A $\boldsymbol{\omega}_{\boldsymbol{j}}$ vektor a korábbi értelmezésben a $j$ országra vonatkoztatva szerepel a képletben, $\mathrm{s}$ itt is igaz, hogy $\partial G^{k}(.) / \partial \boldsymbol{d}_{\boldsymbol{k}}>0$.

$$
G_{j}^{k}=G_{j}^{k}\left(\omega_{j} d_{k}\right)
$$

Így a (8) és (9) kifejezéseket az (5) kifejezésbe behelyettesítve, s a fentieket is figyelembe véve a kivándorlási alternatíva hasznosságát a (10) kifejezés adja meg.

$$
U_{j}^{k}=Y_{j}^{k}\left(\chi_{j} \boldsymbol{d}_{\boldsymbol{k}} ; \theta_{j} S P_{k} ; L M_{j} ; \operatorname{Tr} C_{k}\right)+G_{j}^{k}\left(\boldsymbol{\omega}_{j} \boldsymbol{d}_{\boldsymbol{k}}\right)-C_{m}^{k}-C_{s}^{k}\left(S P_{k}\right)-C_{p}^{k}
$$

Mindezek tükrében, az (1) és (5) kifejezések alapján a (11) kifejezésben felírhatjuk $k$-nak az $i$-ből $j$-be történő kivándorlásának az $N U_{i j}^{k}$-val jelölt nettó hasznát.

$$
N U_{i j}^{k}=U_{j}^{k}-U_{i}^{k}=\left(Y_{j}^{k}-Y_{i}^{k}\right)+\left(G_{j}^{k}-G_{i}^{k}\right)-C_{m}^{k}-C_{s}^{k}-C_{p}^{k}
$$

A (11) kifejezésben foglaltak azt mutatják, hogy az egyén számára elérhető várható jövedelemben és nettó közszolgáltatási szintekben meglévő különbségek ösztönzői lehetnek az elvándorlásnak. Ezekről $\Delta Y \equiv Y_{j}^{k}-Y_{i}^{k}$ és $\Delta G \equiv G_{j}^{k}-G_{i}^{k}$

\footnotetext{
${ }^{78}$ Hallomáson vagy egyéb megfigyelésen alapuló elképzeléssel természetesen rendelkezhet a külföldi ország intézményrendszerére vonatkozóan is, azonban álláspontunk szerint ez az elképzelés vagy várakozás nem azonos a tényleges tapasztaláson alapuló bizalommal. Ez alól az képezhetne kivételt, ha az egyén korábban élt már életvitelszerủen az adott országban, ekkor ugyanis rendelkezhet személyes tapasztalattal az intézményrendszer müködésére vonatkozóan. Tekintve azonban, hogy az ebből a szempontból releváns formális intézmények - mint azt a 2.2. alfejezetben tárgyaltuk - egyik napról a másikra megváltoztathatók, így ezen korábbi tapasztalatai a migrációs döntés meghozatalakor már nem feltétlenül relevánsak. Ez ugyancsak azt az érvünket támasztja alá, hogy egy intézményi bizalomra vonatkozó mutató szerepeltetése a (8) kifejezésben nem indokolt.
} 
összefüggéseket definiálva a következöket mondhatjuk. Ha $\Delta Y>0$ és $\Delta G>0$, s ezek értéke minél nagyobb, $k$ annál nagyobb eséllyel választhatja a $j$-be vándorlás lehetőségét. Az eddig leírtak, illetve a (4) és (10) kifejezések alapján pedig tudjuk, hogy:

- a $\chi_{j}-\chi_{i}$ különbség növekedésével $\Delta Y$ is nö. Azaz, ha $j$ munkaeröpiaca $i$-énél kedvezőbben értékeli az aktor $\boldsymbol{d}_{\boldsymbol{k}}$-ban foglalt egyedi jellemzőit, az ceteris paribus növeli a várható bérkülönbséget. Ennek kapcsán definiálhatjuk a $\Delta \chi \equiv$ $\chi_{j}-\chi_{i}$ összefüggést.

- a $L M_{j}-L M_{i}$ különbség növekedésével $\Delta Y$ is nő. Azaz minél kedvezőbbek a munkaerőpiaci lehetőségek $j$-ben $i$-hez viszonyítva, annál nagyobb a lehetősége $k$-nak is arra, hogy magasabb bért érjen el ott. Ennek kapcsán definiálhatjuk a $\Delta L M \equiv L M_{j}-L M_{i}$ összefüggést.

- $\quad I N_{i}^{k}$ csökkenésével $\Delta Y$ nő, azaz az $i$ intézményrendszerébe vetett bizalom csökkenésével a hazai fizetés kiszámíthatósága, s ezáltal jövőben várt értéke csökken, ami előnyösebb színben tünteti fel a külföldi alternatívát. Ugyanez az összefüggés figyelhető meg $I N_{i}^{k}$ és $\Delta G$ között is.

- $\operatorname{Tr} C_{k}$ csökkenésével $\Delta Y$ várható mértéke nő, ugyanis alacsonyabb tranzakciós költségek mellett $k$ nagyobb eséllyel találhat jövedelmezőbb külföldi lehetőségeket.

- az $\omega_{j}-\omega_{i}$ különbség növekedésével $\Delta G$ nő. Azaz, ha $j$ kormányzatának közpolitikái $i$-énél sokkal kedvezőbbek a $\boldsymbol{d}_{\boldsymbol{k}}$ jellemzőkkel rendelkező egyénnek, az ceteris paribus növeli a várható nettó közszolgáltatási szintben jelentkező különbséget. Ennek kapcsán definiálhatjuk a $\Delta \omega \equiv \omega_{j}-\omega_{i}$ összefüggést.

- ellenben a $\theta_{i}-\theta_{j}$ különbség növekedésével $\Delta Y$ csökken. Azaz, ha az egyén specifikus humántőkéjének hasznosíthatósága külföldön nagyon kicsi, az ceteris paribus csökkenti a külföldön elérhető bértöbblet nagyságát. Ennek kapcsán definiálhatjuk a $\Delta \theta \equiv \theta_{i}-\theta_{j}$ összefüggést. Mivel azonban $\Delta \theta>0$ definíciószerüen igaz, ezért $S P_{k}$ növekedése ceteris paribus minden esetben csökkenti $\Delta Y$ értékét.

A (11) kifejezésből látszik, hogy a nagyobb $\Delta Y$-ból és $\Delta G$-ből származó előnyöket $C_{m}^{k}, C_{s}^{k}$ és $C_{p}^{k}$, így a (10), illetve (7) kifejezések alapján $S P_{k}$, valamint, ha $\sum_{x=x_{1}}^{n} \Delta U^{x}<$ 
0 , akkor $\sum_{x=x_{1}}^{n} \gamma_{x}$ nagyobb értékei csökkenthetik. Ezek a tényezök tehát a kivándorlás ellenösztönzőinek tekinthetők.

Mindezt úgy foglalhatjuk össze, hogy a (11) kifejezés alapján definiáljuk a kivándorlás valószínúségét, amelyet a $\operatorname{Pr}(m i g r)$ jelöl. Ezt a (12) kifejezés mutatja be.

$$
\operatorname{Pr}(m i g r=1)=\operatorname{Pr}\left(\left(Y_{j}^{k}-Y_{i}^{k}\right)+\left(G_{j}^{k}-G_{i}^{k}\right)>C_{m}^{k}+C_{s}^{k}+C_{p}^{k}\right)
$$

ahol migr a migrációs döntés eredményére utal úgy, hogy migr $=\left\{\begin{array}{l}0, \text { ha } k \text { marad } \\ 1, \text { ha } k \text { migrál }\end{array}\right.$.

Az eddig ismertetett összefüggéseket behelyettesítve pedig a (13) kifejezéssel írhatjuk le a migráció valószínűségét, amelyet disszertációnk empirikus vizsgálatai során becsülni is tudunk.

$$
\operatorname{Pr}(\operatorname{migr}=1)=\operatorname{Pr}\left(\begin{array}{c}
\Delta Y\left(\Delta \chi \boldsymbol{d}_{\boldsymbol{k}} ; \Delta L M ; I N_{i}^{k} ; \operatorname{Tr} C_{k} ; \Delta \theta S P_{k}\right) \\
+\Delta G\left(\Delta \boldsymbol{\omega} \boldsymbol{d}_{\boldsymbol{k}} I N_{i}^{k}\right) \\
>C_{m}^{k}+C_{s}^{k}\left(S P_{k}\right)+C_{p}^{k}
\end{array}\right)
$$

Látható, hogy az elvándorlást többféle tényező befolyásolja. Vannak olyanok, amelyekre az egyénnek nincs hatása, míg mások kifejezetten egyedi jellemzők, sőt, ezek közül bizonyos tényezőket még kontrollálni is tud. Előbbi csoportba, tehát az egyéntől független tényezők közé a küldő és fogadó ország jellemzői tartoznak: a munkaerőpiac állapota, az, hogy hogyan értékeli a különböző tulajdonsággal rendelkező munkavállalók kvalitásait, de ide tartoznak az érintett országok közpolitikái is. A mobilitási költségek mértéke ugyancsak ebbe a kategóriába sorolható, igaz, azzal a kitétellel, hogy mértéke függ a kiválasztott célhelytől. Amint azonban a választás a fentiek szerinti kivándorlás vagy maradás dilemmára szükül, már exogén adottságként tekinthetünk rá. A származási ország intézményrendszere ugyancsak külső tényező, az viszont, hogy az egyén milyen bizalommal bír az intézmények iránt, már személyes, így a szelekció alapját is képezheti. Ráadásul - noha ez aligha tudatos döntés eredménye - az intézményekbe vetett bizalom mértéke egy olyan tényező, amelyet valamilyen szinten az egyén is tud befolyásolni. Hasonlókat mondhatunk el az altruista kapcsolatokból fakadó lelki költségekről is: egyedi jellemző, mértékük függ az egyén viselkedésétől, de ez is kevéssé tekinthető tudatosan alakított faktornak. Ezekkel szemben az az egyedi adottság, hogy az aktor mennyi specifikus beruházást eszközölt, már inkább tekinthető a döntései eredményének. Ugyanakkor a migrációs döntés meghozatalakor ez is exogén módon adott állapot-, mintsem kontrollváltozónak tekinthető, hiszen mértékük évek vagy évtizedek eredményeként áll elő. Ettől függetlenül azonban fontos szelekciós tényezőként jelenik meg. A tranzakciós költségek mértéke vegyes képet fest ebböl a szempontból. 
Modellünkben e tényező egyértelmüen az egyedi szelekciós faktorok közé tartozik, hiszen személyenként rendkívül eltérő, hogy ki mekkora mértékü tranzakciós költséggel szembesül a keresés vagy maga a migráció során. Mint azonban azt 2.3.2. alfejezetben kifejtettük, mértékük részben külső adottságok (pl. technológiai lehetőséget), részben pedig az egyén korábbi döntésének (pl. tanult-e idegen nyelvet, rendelkezik-e migrációs hálózattal) függvénye. Végül az egyedi, szelekciós tényezők sorát az aktor $\boldsymbol{d}_{\boldsymbol{k}}$-ban foglalt jellemzőivel zárhatjuk. Ezek között szintén vannak tudatosan befolyásolható tulajdonságok (pl. iskolázottság, szakmai tapasztalat mértéke; munkaviszony megléte; lakhely típusa) és (kvázi) adottságként meglévő attribútumok is (pl. nem, életkor).

Mindezek tükrében modellünk predikcióit, amelyek összhangban vannak mind jelen alfejezet korábbi felsorolásával, mind a Bevezetésben lefektetett hipotézisekkel, úgy foglalhatjuk össze, hogy áttekintjük a (13) kifejezés változók szerinti parciális deriváltjainak előjeleit. Ezeket a 2.1. táblázatban foglaljuk össze. 


\section{1. táblázat}

\section{Az elméleti modell predikciói a (13) kifejezés parciális deriváltjai alapján}

\begin{tabular}{|c|c|c|}
\hline $\begin{array}{l}\text { Parciális } \\
\text { deriválás } \\
\text { változója }\end{array}$ & $\begin{array}{l}\text { Parciális } \\
\text { derivált } \\
\text { előjele }\end{array}$ & $\begin{array}{l}\text { Predikció } \\
\text { (ceteris paribus) }\end{array}$ \\
\hline$\Delta \chi$ & + & $\begin{array}{l}\text { Minél nagyobbak az érintett országok munkaerőpiacainak az egyedi } \\
\text { jellemzők értékelésében meglévő különbségek (a célország javára), annál } \\
\text { nagyobb az egyén elvándorlásának valószínüsége. }\end{array}$ \\
\hline$d_{k}$ & + & $\begin{array}{l}\text { Minél jobb az egyén humántőkéjének a munkaadók szemszögéből vett } \\
\text { minősége, annál nagyobb az elvándorlásának valószínüsége. }\end{array}$ \\
\hline$\Delta L M$ & + & $\begin{array}{l}\text { Minél nagyobbak az érintett országok munkaerőpiacainak jellemzőiben } \\
\text { meglévő különbségek (a célország javára), annál nagyobb az egyén } \\
\text { elvándorlásának valószínüsége. }\end{array}$ \\
\hline$I N_{i}^{k}$ & - & $\begin{array}{l}\text { Minél jobban bízik az egyén a származási ország intézményeiben, annál } \\
\text { kisebb az elvándorlás valószínűsége. }\end{array}$ \\
\hline $\operatorname{Tr} C_{k}$ & - & $\begin{array}{l}\text { Minél nagyobb tranzakciós költségekkel szembesül az egyén, annál kisebb az } \\
\text { elvándorlásának valószínüsége. }\end{array}$ \\
\hline$\Delta \theta$ & - & $\begin{array}{l}\text { Minél nagyobb az egyén specifikus beruházásainak külföldi és hazai } \\
\text { hasznosíthatóságának különbsége, annál kisebb az elvándorlásának } \\
\text { valószínúsége }\end{array}$ \\
\hline$S P_{k}$ & - & $\begin{array}{l}\text { Minél több specifikus beruházást tett az egyén élete során, annál kisebb az } \\
\text { elvándorlásának valószínüsége. }\end{array}$ \\
\hline$\Delta \omega$ & + & $\begin{array}{l}\text { Minél kedvezőbbek az érintett országok közpolitikáinak az egyén számára } \\
\text { jelentkező támogatásaiban és terheiben meglévő különbségek (a célország } \\
\text { javára), annál nagyobb az egyén elvándorlásának valószínűsége. }\end{array}$ \\
\hline$C_{m}^{k}$ & - & $\begin{array}{l}\text { Minél nagyobb mobilitási költségekkel szembesül az egyén, annál kisebb az } \\
\text { elvándorlásának valószínűsége. }\end{array}$ \\
\hline$C_{p}^{k}$ & - & $\begin{array}{l}\text { Minél nagyobb lelki költségek jelentkeznek az elvándorlással az egyén } \\
\text { számára, annál kisebb az elvándorlásának valószínüsége. }\end{array}$ \\
\hline
\end{tabular}

Forrás: saját szerkesztés

\section{5. Összegzés}

Amint azt a fejezetben bemutattuk, elméleti modellünk alapjaiban a migráció neoklasszikus mikroökonómiai megközelítésére épült, azonban azt részben meghaladva, részben más megközelítésekből táplálkozva az intézményi és viselkedési közgazdaságtan paradigmáinak vívmányaival egészítettük ki. Ennek eredményeként egy koherens, közgazdaságtani alapokon nyugvó, általunk intézményi megközelítésünek nevezett migrációelméleti modellt állítottunk fel.

Modellünk szereplője egy korlátozottan racionális egyén, aki elsősorban önérdekkövető, de altruista vonásokkal is bírhat. A migrációs döntés meghozataláig az elvándorlás gondolatának felmerülésétől elindulva egy keresési folyamat lefolytatásán keresztül jut el. Ezen fázisokban - elsősorban kognitív képességeinek korlátai miatt - 
tranzakciós költségekkel is szembesül. Életét nem egy „steril”, „légüres” térben éli, a körülötte lévő intézményrendszerrel is kölcsönhatásban van, s az intézményrendszer müködése, illetve ennek nyomán az abba vetett bizalma is hatással van cselekedeteire. Migrációs döntéseit ezen, s humántőkéjének hasznosíthatóságán felül további faktorok is befolyásolják. Ezek közé tartoznak a már említett tranzakciós költségek, az altruista attitüd nyomán jelentkező lelki költségek, valamint az általa meghozott specifikus beruházások is.

Utóbbi tényezőkkel modellünk újabb, közgazdaságtani alapokon nyugvó, egységes elméleti keretbe foglalt adalékokkal szolgál az irodalmi áttekintésben már említett, hiányzó migráció vagy helyben maradás rejtélyének nevezett empirikus puzzle magyarázatára. Amíg ugyanis a neoklasszikus elméletekben (akár azok verbális felírásában, akár formalizált modelljeiben) elsősorban az általunk mobilitási költségként aposztrofált tényezők és némi véletlen faktor (lásd például Huber \& Nowotny, 2013) tudtak a hatalmas bérkülönbségek ellenösztönzőiként szolgálni, addig - mint azt a 2.1. táblázat is mutatja - itt több ilyen tényezőt is azonosítottunk, s építettünk be egy egységes fogalomrendszerü modellbe. Hangsúlyozandó az is, hogy ezek egy neoklasszikus modellben - első megközelítésben - akár elhanyagolható tényezőknek is tünhetnének. Jelen disszertáció korlátozott racionalitásra épülő keretrendszerében azonban értelmet nyer, hogy ezek a faktorok miért tudnak - objektíve kisebbnek tekinthető súlyuk ellenére is - olyan fontos szerepet játszani az egyén szubjektív szemszögéből felépített kognitív keretben. Mindezek alapján pedig úgy véljük, hogy a tranzakciós költségek, a specifikus beruházások, az altruista vonások és az intézményi müködésbe vetett bizalom is fontos befolyásoló tényezői lehetnek az elvándorlási döntéseknek, s ezáltal a migránsok szelekciójának is. Disszertációnk empirikus elemzésében ezt kívánjuk igazolni. 


\section{ADATOK}

A 2. fejezetben bemutatott elméleti modellünk empirikus teszteléséhez az első lépést a megfelelő adatok megtalálása és kiválasztása jelenti. Amint azonban arra már korábban is utaltunk, a migrációkutatásban pontosan ez jelenti az egyik legnagyobb kihívást. A konceptualizációs, regisztrálási vagy éppen összehasonlíthatósági nehézségek mellett ugyanis számos további, kisebb és nagyobb probléma jelentkezik a migrációs statisztikák használata során. Ezeknek valamely - általában saját kutatásuk szempontjából releváns - aspektusát az egyes szerzők is rendre említik, így ilyenekkel Bauer \& Zimmermann (1995), Castro-Martín \& Cortina (2015), Gödri (2015), Gödri \& Feleky (2013), illetve Zaiceva \& Zimmermann (2008a) írásaiban is találkozhatunk. Némiképp szisztematikusabb áttekintést nyújtanak a migrációs adatokkal kapcsolatos problémákról Blaskó \& Gödri (2014), Blaskó, Ligeti, \& Sik (2014), Lakatos (2015), valamint Tóth (2012, szerk.) munkái, azonban ezekben a rendezőelvet inkább a különböző adatforrások adják. Azt veszik számba, hogy milyen lehetséges adatforrások állnak a kutató rendelkezésére, azok milyen előnyökkel és hátrányokkal bírnak, s ezek tükrében adnak különböző becsléseket a külföldön élő polgárok számára vonatkozóan.

A migrációs adatokkal kapcsolatos problémák áttekintése disszertációnk szempontjából is kiemelt fontosságú. Egyrészt vizsgálatunk kontextusba helyezése szempontjából, másrészt pedig azért, hogy indokoljuk, miért az általunk választott adatszett a legalkalmasabb hipotéziseink tesztelésére. A különböző adatforrásokhoz kapcsolódó kihívások áttekintése során támaszkodni fogunk a fent hivatkozott munkákban leírtakra is, ugyanakkor diszkussziónk vezérfonala eltér az előbbiekétől. A különböző adatforrás(típus)ok számbavétele helyett a kutatók előtt álló dilemmák és kihívások mentén tekintjük át a problémakört, amellyel szándékunk szerint egy újszerü szemléletmódban, átfogóan dolgozzuk fel a témát. Ezt a 3.1. alfejezetben tesszük meg, amelyet az ott leírtak tükrében a 3.2. alfejezetben jelen disszertáció adatszettjének bemutatása követ majd.

\subsection{Adatokkal kapcsolatos dilemmák, kihívások}

A migrációs adatokkal kapcsolatos legelső dilemmát a definíció jelenti: már az sem egyértelmü, kit tekinthetünk migránsnak. A statisztikai adatbázisok e tekintetben általában kétféle megközelítést alkalmaznak: azokat definiálják migránsként, akik a születési helyük vagy az állampolgárságuk szerinti országtól eltérő helyen élnek. 
Azonban mindkét alternatíva esetén merülnek fel kérdések és kétértelmüségek. Gondolhatunk ennek kapcsán a többes állampolgársággal rendelkezőkre, a másod- vagy harmadgenerációs bevándorlókra, akik megtartották korábbi állampolgárságukat, de akár az a dilemma is megfogalmazódhat, hogy feltétlen migránsként kell-e számontartanunk egy olyan személyt, aki hosszú évtizedeket, állampolgárságot is felvéve egy másik országban élt le, s ahhoz, amelyikben született, egyáltalán nem köti semmi. A válasz erre a kérdésre egyértelmű igen és egyértelmű nem is lehet, azt elsősorban a vizsgálat célja dönti el. E meghatározások emellett egy újabb konceptualizációs dilemmához vezet: mit értünk egy adott országban való ,élés” vagy életvitelszerü tartózkodás alatt. Erre a kérdésre a választ gyakran a bejelentett lakcímmel való rendelkezés jelenti, azonban ezzel a nemzetközi vándorlásokban részt vevőknek jelentős köre esik ki a szürőből. Ennek alternatívája (vagy kiegészítője) lehet, ha egy bizonyos, az országban töltött idő után tekintenek valakit migránsnak. A statisztikai nyilvántartásokban gyakori, hogy ezt az időtávot egy évben határozzák meg, azonban ez sem kizárólagos: jó példa erre, hogy míg az Eurostat egy év eltöltött idő után tekint bevándorlónak valakit, addig ez a korlát a német bevándorlási statisztikában mindössze három hónap. Jóllehet, mindkét konstrukció indokolható valamilyen szempontok szerint, a meghatározás valójában esetleges, s csak döntés kérdése. Ez azonban a különböző forrásból érkező adatok nemzetközi összehasonlíthatóságát nehezíti.

Utóbbiak alapján jól látható, hogy a kiinduló fogalom meghatározásakor van egy időbeliségi dilemma is: mi az az időtáv, amitől már és mi az, amikor még migránsnak tekinthetünk valakit? Ez a problematika két szélsőséges példával szemléltethető: a jelenkori magyar kivándorlási statisztikában nem biztos, hogy szerepeltetni akarunk egy olyan fiatalt, aki néhány hónapig külföldön kíván szerencsét próbálni, de valószínüleg az is torzítaná az aktuális folyamatokról alkotott képet, ha ugyanebben az adatbázisban figyelembe vennénk például az 56-os menekülteket. Ezen dilemmák eldöntése ugyancsak a kutatási céltól függhet. Az mindenesetre elmondható, hogy a maximális időtáv meghatározására általános gyakorlat nincs, s a „túl régóta” külföldön élőket inkább a flow adatok (lásd később) használatával tudjuk kiszürni. A minimum időtávra - mint azt már jeleztük - eltérő meghatározások vannak, de legelterjedtebbnek az egy éves időtartam mondható. Ez a definíció azonban figyelmen kívül hagyja a nemzetközi áramlások jelentős szeletét, így a rövid távra - akár 364 napra - külföldre költözőket, illetve az ingázó munkavállalókat, akik ugyanakkor szintén érdekesek lehet(né)nek bizonyos vizsgálatokban. 
Bárhogyan $^{79}$ is definiáljuk a migránsokat, azok csak úgy tudnak megjelenni a statisztikákban, ha valaki regisztrálja őket. Itt elsőként az a dilemma vetődhet fel, hogy hol végezzék a regisztrációt: a küldő vagy a fogadó országban? Előbbiek számára ez általában súlyos nehézségeket okoz, ugyanis napjainkban az emberek könnyedén távozhatnak egy másik országba anélkül, hogy a származás szerinti állam hatóságai tudomást szereznének erről (különösen igaz ez például az EU schengeni övezetére, ahol a polgároknak még csak határellenőrzéssel sem kell számolniuk). Az elvándorlóknak ugyan formálisan lehetnek bizonyos kijelentkezési kötelezettségei (Magyarország esetében lásd például Gödri, 2018), ezek köre általában elég szűk, s koránt sem biztos, hogy a polgárok eleget tesznek neki. Ez egyrészt fakadhat abból, hogy maguk sem tudják, mennyi időre távoznak, s vissza kívánnak-e egyáltalán térni, másrészt a szabályok kikényszeríthetőségének hiánya is közre játszhat ebben. A bejelentés hiányában ugyanis a hatóságok nem értesülnek a távozásról, s még ha tudomást is szereznek róla, az utolérhetetlenség miatt gyakran nem tudják szankcionálni a mulasztást. Kiegészítve ezt a kijelentkezés adminisztratív terheivel, világos, hogy a kivándorlóknak valójában igen alacsony ösztönzöttsége lehet a távozás bejelentésére. ${ }^{80}$ Mindezek tükrében a származási országban regisztrált kivándorlási adatok általában hiányosak, s csak egy bizonyos szegletét fedik le az elvándorlóknak.

A célországban regisztrált adatok e tekintetben teljesebbnek tekinthetők. A küldő ország szempontjából ezeket tükörstatisztikáknak szokás nevezni. Itt ugyanakkor ismét ahhoz a problémához térünk vissza, hogy amennyiben az egyes országok eltérően definiálják a migránsok fogalmát, s egyéb módszertani kérdésben is eltérő gyakorlatot követnek, úgy az ellehetetleníti a nemzetközi összegezhetőséget és

\footnotetext{
79 Valójában persze a regisztrálás szempontjából sem mindegy, hogy kiket tekintünk migránsnak. Ha ugyanis a rövidebb ideig (például kevesebb, mint egy évi) külföldön tartózkodókat is migránsként definiálnánk, akkor sem biztos, hogy a gyakorlatban is nagyságrendekkel nagyobb értékek jelennének meg a statisztikákban a vándorlók számára vonatkozóan. Még akkor sem, ha tudjuk, jelentős tömegekről van szó. A rövid tartózkodási idővel ugyanis együtt jár, hogy regisztrálni is nehezebb a szóban forgó vándorlókat, így egyáltalán nem biztos, hogy mindannyian megjelennének a nyilvántartásokban. Mindezek tükrében általánosan is megfogalmazható, hogy a következőkben tárgyalt nehézségek a különböző időtávra migrálók esetén változó erősséggel jelenhetnek meg.

${ }^{80}$ Kivételt képeznek ez alól azon esetek, ahol a kivándorlóknak érdeke füződik valamilyen adminisztratív aktus megtételéhez. Jó példa erre a magyar orvosok kivándorlása, amelyhez utóbbiaknak szüksége van egy hatósági bizonyítványra a külföldi munkavállaláshoz szükséges szakképesítés igazolásához. Ezt Egészségügyi Nyilvántartási és Képzési Központtól (ENKK) tudják kérni, amely így pontos adatbázissal rendelkezik a kiadott hatósági bizonyítványokról. Megjegyzendő persze, hogy ezek az ENKK adatok csak egy felső becslését adják az orvos-elvándorlásnak, hisz a hatósági bizonyítvány igénylése csak egy szükséges és nem elégséges feltétele a külföldi munkavállalásnak.
} 
összehasonlíthatóságot. ${ }^{81}$ A tükörstatisztikák között külön kiemelést érdemelnek a különböző hatósági regiszterekből érkező adatok, így például a munkavállalási engedélyek vagy társadalombiztosítási regisztrációk. Ezek ugyanis az érintett populációról (értsd: munkavállalók vagy társadalombiztosítást igénylők) pontos és közel teljes információs bázissal szolgálnak, így az adott körre vonatkozó következtetések levonására jól használhatók. Hátrányuk ugyanakkor, hogy a migránsok jókora részét nem tartalmazzák, így felülnézetböl csak proxykként szolgálhatnak a nemzetközi áramlások vizsgálatára, $\mathrm{s}$ azon belül is inkább a trendek alakulásának nyomon követésére alkalmasak. Azon országok viszonylatában pedig, amelyek egymással szemben szabad mozgást engedélyeznek az állampolgáraik számára - tehát vízum- vagy bármilyen bevándorlási, illetve munkavállalási engedélykötelezettséget nem írnak elő - még ilyen jellegü adatok sem állnak rendelkezésre. Ez az EU-n belüli mozgások alaposabb vizsgálatát is érdemben megnehezíti.

Szintén fontos kérdésként merül fel a kutató számára az, hogy stock vagy flow adatokat használjon. Előbbiek jellemzően egy adott országban tartózkodó migránsok állományára vonatkozóan nyújtanak információt, míg utóbbiak arról, hogy egy adott időszakban hányan éltek a migráció - valamilyen formájú, valamilyen módon definiált lehetőségével. A stock adatok jellemzően inkább bevándorlási jellegü adatbázisokból származnak, amelyeket a fogadó országokban rögzítenek, így többnyire a már tárgyalt előnyökkel és hátrányokkal rendelkeznek. ${ }^{82} \mathrm{Az}$ állományi adatok pozitív vonása, hogy általában könnyebben hozzáférhetők, hiszen elsősorban ezek találhatók meg viszonylagosan egységes módszertannal számba véve, így időbeli és térbeli összehasonlításra is alkalmas módon - a nagy nemzetközi szervezetek (például az ENSZ, az OECD vagy éppen az Európai Unió) statisztikai adatbázisaiban. ${ }^{83}$ A negatív vonások között azonban több tényezőt is felsorakoztathatunk. Egyrészt statikus képet adnak a migrációról, így aktuális folyamatok elemzésére kevéssé alkalmasak: az aggregált állományi adatokból ugyanis általában nem derül ki, hogy ki mikor érkezett az adott

${ }^{81}$ Értsd: ha egy származási ország a tükörstatisztikák alapján kívánja összegezni, hogy hány kivándorlója volt a megelőző időszakokban, azt a célországok eltérő definíciói miatt aligha tudja konzekvens módon megtenni.

82 Természetesen találkozhatunk származási országban regisztrált állományi adatokkal is, ilyenek lehetnek a népszámlálások során felvett adatok a külföldön tartózkodó hozzátartozókról, illetve a különböző speciális célú, megkérdezéses survey adatok. Ezek jellemzőit a későbbiekben tárgyaljuk részletesen.

${ }^{83}$ Megjegyzendő persze, hogy az egységes módszertan inkább csak célkitűzésként fogalmazódik meg ezen adatbázisok esetében is, s itt sem beszélhetünk mindig százszázalékos homogenitásról. Ennek oka, hogy a nemzetközi szervezetek is a nemzeti statisztikai hivatalok adatszolgáltatásaira tudnak támaszkodni, s csak az azoktól érkező információkat összesítik. Ebből kifolyólag egységesebb módszertan alkalmazására azon esetekben van lehetőség, ahol - mint például az EU-ban - erre vonatkozó szabályok is léteznek. 
országban. Ráadásul - a definícióból fakadóan - általában a rövid időtávra migrálók is kimaradnak e statisztikákból. Ezek ugyanis adott időpillanatokban tekintenek a sokaságra, így nem számolnak azokkal, akik két egymást követő adatfelvételi időpont között érkeztek és távoztak. Ez ráadásul azt is megnehezíti, hogy a stock adatokat kvázi flow adatokká alakítsuk, s a differenciák segítségével képet kapjunk az évenkénti folyamatokról. Ez a számok „,nettósított” értékéből adódik: amennyiben nem tudjuk külön regisztrálni az elmenőket és az érkezőket, úgy azonos mértékü ki- és beáramlás mellett az állományi adatok értéke évről-évre változatlan maradhat, ami azonban nem adja vissza jól a valódi történéseket. ${ }^{84}$

A flow adatok ezzel szemben az aktuális trendeket világítják meg. Hátrányuk ugyanakkor, hogy a külföldön töltött időtartamáról, illetve a hazatérésről nem szolgálnak információval. Szintén torzítást okozhat, hogy bizonyos flow típusú, proxyként szolgáló adatok rögzítésére - ilyen például az Egyesült Királyságbeli biztosítási szám igénylése minden ember életében egyszer kerül, így ezek a tendenciák elemzésére alkalmasak, de konkrétabb becslések készítésekor csak megfelelő fenntartásokkal használhatók.

Az aggregált adatok esetén - amennyiben rendelkezésre állnak - az is dilemma elé állítja a kutatókat, hogy a bruttó vagy a nettó migrációs adatok, esetleg a (bruttó/nettó) migrációs ráták tudják legjobban megragadni a nemzetközi vándorlások fő vonásait. A kérdést, hogy ezek milyen előnyökkel és hátrányokkal járnak a különböző elemzésekben Bauer \& Zimmermann (1995), illetve Krugman \& Bhagwati (1976) tárgyalja részletesen. A bruttó migráció egy bizonyos országból egy másikba vándorló emberek nyers számára utal, a nettó migráció pedig egy adott ország viszonylatában mutatja meg a ki- és bevándorlás egyenlegét. Előbbi nyers számokat jelöl az áramlás mértékéről, ezért nem torzít, ugyanakkor komplexebb, többfókuszú elemzésekre önmagában kevéssé alkalmas. Nem számol ugyanis sem a teljes populáció méretével, sem az ellentétes irányú mozgásokkal, így például arról, hogy egy ország mennyire vonzó - vagy éppen taszító a nemzetközi migránsok számára, nem ad disztingvált képet. Erre bizonyos szempontból alkalmasabb a nettó migrációs mutató, azonban amennyiben a ki- és bevándorlás mértéke korrelál, úgy az indikátor erősen torzított lesz. ${ }^{85}$ Mivel azonban ez a mutató sem számol

\footnotetext{
${ }^{84}$ A bruttó és nettó adatok jellemzőit később részletesen is tárgyaljuk.

${ }^{85}$ Bár a nettó migráció a bevándorlás és a kivándorlás abszolút különbségeként definiálható, a gyakorlatban a mutatót - pontosan a jelen alfejezetben tárgyaltak okán - mégsem minden esetben így állítják elő. Jó példa erre az Eurostat adatbázisa, ahol a statisztikailag igazított nettó migrációs ráta (net migration plus statistical adjustment) teljesen „mesterségesen” úgy áll elő, hogy az évenkénti népességváltozás mértékéből levonják a természetes szaporodás és fogyás különbségét.
} 
az országok populációjával, $\mathrm{s}$ tekintve, hogy egy jelentősen népesebb állam nagyságrendekkel nagyobb kivándorló-tömeget is képes kibocsátani, ezért gyakran alkalmazott indikátor a migrációs ráta is. Ez - választás szerint - a bruttó vagy a nettó kivándorlás mértékét vetíti rá a származási ország népességére, s így ad egy arányszámot a migráció mértékéről.

Mindezen túl újabb kihívást jelent a migrációkutatók számára, hogy a statisztikai adatbázisokban tárolt adatok egyedi információkat nem, vagy csak minimális mennyiségben tárolnak a vándorlókról. Fontos azonban látni, hogy a mikroszintü adatokra más típusú, célú kutatásokban van szükség. Míg az eddig tárgyalt problémák jelentős része az elé gördít akadályokat, hogy a migránsok pontos számáról tudjunk konkrétumokat megfogalmazni, az egyedi adatok - mint azt az 1.2. alfejezetben már érintettük - inkább az elvándorlók szelekciójának, s az elvándorlás mozgatórugóinak megértéséhez szükségesek. Mivel e témák is kardinális részei a migrációkutatásnak, erős igény mutatkozik az ilyen, egyedi információkat is tároló adatbázisokra is. Ezek száma és hozzáférhetősége azonban rendkívül szük, ami ismét a regisztrálás nehézségeire vezethető vissza: a mikroszintű adatok felvételéhez ugyanis a kivándorlóknak nem csak a „megszámlálása”, hanem a „kikérdezése” is szükséges lenne.

A megkérdezésen alapuló, hivatalos, teljeskörüségre törekvő és a megkérdezettekről megfelelő mennyiségü, illetve minőségü adatot tároló források között gyakorlatilag egyet, a népszámláláson alapuló adatbázist említhetjük. Mindazonáltal ez az adatbázis sem tökéletes. Ha a küldő ország kivándorlóit annak saját népszámlálása alapján akarjuk vizsgálni, akkor róluk csak abban az esetben tudunk információhoz jutni, ha van még olyan családtagjuk, akik odahaza él. Amennyiben az egész család külföldre költözött, úgy nem kerül róluk információ az adatbázisba. Ez azonban a reprezentativitás szempontjából jelentősen torzíthatja az összképet. Erre az sem jelent automatikus megoldást, ha tükörstatisztikaként a fogadó országok népszámlálási adatait tekintjük át. Az eltérő módszertanok, adatfelvételi időpontok, valamint a célországok számossága miatt ugyanis ezek aligha összehasonlíthatók, illetve összegezhetők. Ráadásul ez esetben a megfelelő „kontrollcsoport” hiánya is problémát okozhat: ha a vizsgálat célja az elvándorlás szelekciós tényezőinek felderítése, úgy ahhoz összehasonítás gyanánt elengedhetetlen lenne egy megfelelő - a külföldi népszámlálással minden tekintetben azonos felmérésből származó - adatbázis az otthonmaradó népességről is. Végül, de nem utolsó sorban pedig az is érdemi probléma, hogy a népszámlálásokra ritkán, általában tíz 
évente kerül sor, így ezek adatai csak keresztmetszeti elemzésekre, illetve a nagyon hosszú távú trendek vizsgálatára alkalmasak.

A népszámlálással kapcsolatos problémák egy része azzal a „kompromisszummal” mérsékelhető, ha feladjuk a teljeskörüségre törekvés elvét, $\mathrm{s}$ helyette mintavételes adatokkal dolgozunk. A migránsok jellemzőinek feltérképezésére irányuló mintavételes megkérdezések esetén azonban - többek között a korábban már tárgyalt nehéz elérhetőség miatt - a reprezentativitás csak ritkán biztosítható. Ez összefüggésben áll azzal a jelenséggel is, hogy az elvándorlók a legtöbb országban csak nagyon kis százalékát teszik ki a népességnek. Ez a tény pedig amellett, hogy a következtetések teljes populációra történő kivetíthetőségét bizonytalanítja el, még a statisztikai és ökonometriai vizsgálatokban is módszertani problémákhoz vezethet. A megkérdezés természetesen irányulhat kizárólag a migránsokra is, azonban ez esetben ismét a megfelelő „kontrollcsoport” hiánya jelenthet gondot. ${ }^{86}$ További problémát okoz a megkérdezéses eljárásokban az is, hogy a migránsok egyedi jellemzőit a kivándorlás megtörténte után rögzítik, így azok többnyire a válaszadóknak az akkori külföldi attribútumait, életkörülményeit írják le. ${ }^{87}$ Ezek azonban az elvándorlás okainak meghatározására, s a szelekciós tényezők beazonosítására kevéssé alkalmasak. A survey kérdései természetesen vonatkozhatnak a migráns elvándorlás előtti életére is, azonban ezen információk megbízhatósága hagyhat kérdéseket maga után. Ez a megbízhatósági faktor pedig a migráció és a lekérdezés között eltelt idő növekedésének függvényében tovább csökkenhet: egyrészt az ember kognitív képességeinek korlátossága miatt, másrészt pedig azért, mert mint Gödri és Feleky $(2013$, 282. o.) fogalmaz „,a migrációval kapcsolatos korábbi motivációk, attitüdök, preferenciák és várakozások megítélése módosulhat".

\footnotetext{
${ }^{86}$ Ez alól kivételt képezhetnek például a munkaerőfelmérés (MEF) adatai, ezek azonban a teljes népességnek csak egy szükebb csoportjára, a magyar munkaerőpiachoz háztartásuk révén kötődő, de külföldi telephelyen dolgozó - Hárs \& Simon (2016b) megfogalmazásában - munkaerőmigránsokra fókuszálnak. További, jelen alfejezetben részletezett nehézségek azonban ezen adatok esetén is fennállnak. 87 Jól szemléltethető ez a problematika az általunk felhasználandó, s a 3.3. alfejezetben részletesen bemutatandó 2008-as Euobarometer felmérés adatszettjének példáján. Az adatbázis alapját képező kérdőív ugyanis tartalmaz arra vonatkozó kérdést, hogy a válaszadó abban az országban született-e, ahol a felvétel időpontjában élt. Az erre adott válaszok alapján ugyan képezhetnénk egy „migráns” kategóriát, de azt nem tudnánk felhasználni arra, hogy egy regresszió segítségével beazonosítsuk a migráció szelekciós tényezőit. A survey egyéb kérdései ugyanis az akkori aktuális állapotokra, s nem a migráció időpontjára vonatkoztak. Így a migrációs modellekben szokásos változók (például kor, iskolázottság, családi állapot, munkaviszony stb.) magyarázó változóként történő szerepeltetése nem csak értelmetlen, de szakmailag is hibás döntés lenne, hiszen azokat az időbeli eltérés miatt nem elvi szinten sem lehetne a migráció (okozat) esetleges magyarázó tényezöi (okok) között szerepeltetni.
} 
Összességében tehát valóban az látható, hogy a kutató számos dilemmával, kihívással és problémával szembesül a migrációs adatok keresése, illetve felhasználása során. Ezek egy része a jelen disszertáció empirikus vizsgálatához szükséges adatok kiválasztásakor is jelentkezett. Az nem volt kérdés, hogy elméleti modellünk teszteléséhez - amely a migrációs döntés egyéni szintü befolyásoló tényezőire vonatkozóan fogalmazott meg hipotéziseket - mikroszintü adatokra van szükségünk, amelyek egyedi jellemzőket is rögzítenek. A szelekciós tényezők azonosításához ráadásul az is elengedhetetlen, hogy a felhasználásra kerülő adatbázis kivándorlókra és otthonmaradókra vonatkozóan egyaránt tartalmazzon összevethető adatokat. Ezzel a kritériummal azonban a fogadó országok hatósági regisztereiből igényelhető adatok, amelyek a bevándorlókról esetleg egyedi információkat is tárolnak, kiestek a szürőn. A népszámlálási, illetve az általunk ismert megkérdezésen alapuló adatbázisok kapcsán továbbá az a probléma jelentkezett, hogy azok nem tartalmaztak olyan specifikus információkat, amelyek proxyként szolgálhattak volna hipotéziseink tesztelése során. Ennek egyfajta megoldását egy saját felmérés készítése jelenthette volna, azonban a jelen alfejezetben részletezett kihívások miatt nem láttuk volna biztosítottnak azt, hogy erőforrásainkból egy kellő nagyságú, reprezentatív és a szakmai szempontoknak is eleget tevő felmérést készítsünk. Mindezek tükrében modellünk teszteléséhez a tényleges vándorlási adatok felől a migrációs hajlandóságra vagy más néven migrációs potenciálra vonatkozó adatok felé fordultunk, amelyek számos olyan - a továbbiakban ismertetendő - pozitív vonással rendelkeznek, amelyek alkalmassá teszik őket az empirikus vizsgálatokban történő felhasználásra.

Sik (2003, 15. o.) megfogalmazásában migrációs potenciálnak az arra vonatkozó a szándékot nevezzük, hogy „,valaki külföldön vállaljon munkát vagy kivándoroljon”, így az indikátor azt mutatja meg, hogy ,a népességen belül mekkora azok köre, akik migrációt terveznek”. Mint arra felhívja a figyelmet, a „definícióban nem véletlenül szerepel egyszer a »szándék «, másszor a »terv« kifejezés”, ez elsősorban arra utal, hogy a migrációs potenciál meghatározása, s ezáltal mértéke is nagyban függ a kérdezés szóhasználatától. Mindazonáltal a különböző megkérdezések révén előálló mutatókat egyaránt migrációs potenciálnak nevezzük, amely gyakran használatos szinonimaként a migrációs szándék, kedv vagy hajlandóság kifejezésekkel, a konkrét eredményeket azonban mindig az eredeti surveyben használt kérdés szóhasználatának tükrében kell értelmezni. 
A migrációs potenciálra vonatkozó adatok tehát szintén megkérdezéses vizsgálatból nyerhetők, a különbséget az jelenti, hogy itt a válaszadót nem a migrációs múltjáról, hanem az arra vonatkozó jövőbeli szándékairól kérdezik. Ennek tükrében, mint azt Sik \& Szeitl (2016a; 2016b) megjegyzik, a migrációs potenciál munkaerőpiaci szempontból inkább egyfajta kínálati mutatónak tekinthető. Mivel ennek tükrében egy felső becslést ad a lehetséges elvándorlás maximálisan elképzelhető mértékére, ezért a jövőbeni folyamatok várható alakulásának a becslésére csak nagyon korlátozottan alkalmas. Idősoros összehasonlításban azonban érdemi információval szolgál a kivándorlásról való gondolkodás tendenciáiról, s egyfajta hangulati mutatóként is értelmezhető. Emellett keresztmetszeti - vagy megfelelő adatbázis esetén panel- vizsgálatokban a szelekció természetének megértéséhez is hozzásegíthet azáltal, hogy beazonosíthatjuk, mely vonásokkal rendelkező egyéneknél formálódik meg inkább az elvándorlás gondolata.

Sik (2003) bemutatja az indikátor fajtáit is: míg az általános migrációs potenciál a teljes népességre vonatkozik, addig a speciális migrációs potenciál annak valamely szegletére fókuszál. Így az utóbbiak révén levont következtetések érvényességi köre szűkebb lesz ugyan, de az adott csoportra nézve megbízhatóbb eredményekre vezet. Emellett megkülönböztethető a nyers és a tisztított migrációs potenciál is. Előbbit általánosabb, akár konkrétumokat is nélkülöző migrációs szándékra vagy hajlandóságra vonatkozó kérdésekből nyerhetjük. Amennyiben azonban a kérdőív tartalmaz olyan kérdéseket, amelyek arra keresik a választ, hogy az egyénnek vannak-e konkrétabb elképzelései is vagy esetleg tett már lépéseket az kivándorlás előkészítésére, azok segítségével szürhetünk egy komolyabb szándékokkal rendelkező csoportra, ami egyúttal a tisztított migrációs potenciál mutatójának előállítását is lehetővé teszi. Disszertációnk következő alfejezetben bemutatásra kerülő adatszettje az általános kategóriába tartozik, tehát a népességnek nem egy speciális szegletére utal. Vizsgálatainkat elsősorban nyers migrációs potenciálra vonatkoztatva végezzük el, de a robusztusabb eredmények érdekében hipotéziseinket tisztított migrációs potenciál mellett is teszteljük.

Azt természetesen továbbra is fontos hangsúlyozni, hogy a migrációs szándéknak a - survey-kérdésre adott válaszként történő - megfogalmazása nem azonos a tényleges elvándorlással. Ezen terveknek, szándékoknak ugyanis a gyakorlatban csak egy része valósul meg ténylegesen. Ennek ellenére a migrációkutatásban mégis bevett gyakorlatnak számít, hogy a migráció befolyásoló tényezőit és szelekciós faktorait ilyen, hajlandósági 
adatok segítségével vizsgálják (lásd az 1.3. táblázat függő változói oszlopát). Ez több érvvel is alátámasztható, amelyeket az alábbiakban ismertetünk.

Mindenekelőtt elmondható, hogy a migrációs potenciál adatok mintavételi szempontból több olyan jó tulajdonsággal rendelkeznek, amelyekkel a tényleges migrációra vonatkozó adatok - a jelen fejezet korábbi részében tárgyalt okokból kifolyólag - nem bírnak. Ezek között elsőként a reprezentatív mintavétel lehetősége emelhető ki: míg erre a tényleges migráció esetén a kivándorlók regisztrálhatatlansága, $\mathrm{s}$ az ebből fakadó ismeretlensége, elérhetetlensége miatt nincs lehetőség, az elvándorlási potenciál felmérésekor „csak” a helyben maradók körében kell reprezentatív adatfelvételt lefolytatni, ami lényegesen egyszerübb feladatnak bizonyul. ${ }^{88} \mathrm{Ez}$ egyúttal arra ad lehetőséget, hogy a kivándorlási szándékot megfogalmazókat minden szempontból azonos (értsd: a küldő országbeli életre vonatkozó, azonos időben és azonos módszertannal rögzített) paraméterek mentén - a helyben maradni tervezőkkel vessük össze. Ráadásul a potenciális migránsok aránya rendszerint érdemben nagyobb is a tényleges elvándorlókénál, így az elöbbiekre vonatkozó adatok használata - a regressziók függő változójának nagyobb varianciája miatt - ökonometriai szempontból is jobban használható modellek tesztelését teszi lehetővé.

Gödri \& Feleky (2013) szerint a migrációs hajlandóságra vonatkozó adatok használata azért szerencsés a migrációkutatásban, mert azok az önszelekciós folyamat első lépcsőjére vonatkoznak, amely így még mentes a fogadó országok „kereslet oldali” hatásainak (például bevándorláspolitikai rezsimjeinek) torzításától. Ellenvetésként megfogalmazzák ugyan, hogy a későbbi fázisban újabb szelekciós faktorok is beléphetnek, amelyek végül azt eredményezik, hogy a migrációs tervek nem valósulnak meg. Ez azonban nem kizáró ok arra, hogy ilyen adatokat alkalmazzunk elméleti modellünk empirikus tesztelésére. A kivándorlási szándék megfogalmazása időben minden esetben megelőzi a tényleges döntést, így a potenciális migránsok köre szükségszerüen bővebb a tényleges elvándorlókénál. Ez alapján pedig a következő fázisokban belépő szelekciós tényezők empirikus modellbe történő bevonása is egy következő vizsgálat tárgya lehet. Mindez pedig összhangban van azzal a társadalomtudományi gyakorlattal, hogy az empirikus vizsgálatok során nem az oksági kapcsolat létét igyekszünk igazolni, hanem azt az alternatív hipotézist próbáljuk cáfolni, mely szerint két változó között semmilyen összefüggés nincs. Ennek megfelelően, ha nem

${ }^{88}$ Itt inkább csak az okozhat némi torzítást, hogy a korábban már ténylegesen elvándorlók, azaz akiknél a migrációs szándék már megvalósult, kiesnek a körből. 
tudjuk kizárni, hogy bizonyos tényezők már a migrációs szándék megfogalmazására is hatással vannak, akkor ugyanezt a később következő migrációs döntés esetében sem tudjuk megtenni.

Gödri \& Feleky (2013) irodalmi áttekintése, valamint saját vizsgálata alapján vegyes kép mutatkozik a migrációs szándékok és a kivándorlás megvalósítása közötti kapcsolatról. Az azonban mindenképp elmondható, hogy a migrációt korábban tervezők sokkal nagyobb valószínüséggel döntenek az elvándorlás mellet, mint azok, akiknek nem voltak ilyen szándékaik. Ezt Böheim \& Taylor (2002), valamint Speare (1974) munkái is megerősítik, továbbá Landale \& Guest (1985) is arra jutott, hogy a migrációról való gondolkodás jó előrejelzője a tényleges elvándorlásnak. Ugyanakkor az is kitűnik az empíria áttekintéséből, hogy sokan nem valósítják meg a korábbi terveiket. Gödri \& Feleky (2013) Erdélyre fókuszáló vizsgálatában például a migrációs terveket csak 17 százalékban követte három éven belül tényleges elvándorlás. Ez az arány azonban mind van Dalen \& Henkens (2013) hollandiai, mind De Jong és mtsai. (1986) fülöp-szigeteki vizsgálatában jóval magasabb volt. Elöbbiek eredményei szerint öt éven belül 34 százalékban, utóbbiak eredményei szerint pedig két éven belül 44 százalékban valósították meg a migrációt tervezők az elvándorlást. Ezen megvalósulási arányok pedig már valóban jelentősnek mondhatók. ${ }^{89}$

Emellett egy másik szemszögből is igazolható a migrációs hajlandóság és a tényleges elvándorlás közötti - Zaiceva \& Zimmermann (2008a, 439. o.) megfogalmazásában „magas korreláción” alapuló - kapcsolatot. Amint ugyanis Sik \& Szeitl (2016a) megjegyzik, a ténylegesen kivándorlók szociodemográfiai jellemzői nagyon hasonlítanak a migrációs potenciál-kutatásokban elvándorlási hajlandóságot mutató emberekéihez. Mindezt elméleti szempontból Sik \& Örkény (2003) tárgyalta részletesen, akik a migrációs potenciál létrejöttét magyarázó okok között gyakorlatilag a tényleges migráció hajtóerőivel megegyező tényezőket sorakoztattak fel. Ezen erős párhuzamokat Blanchflower, Saleheen, \& Shadforth (2007), valamint Zaiceva \& Zimmermann (2008b) empirikus elemzései is alátámasztották, ami ismét abba az irányba mutat, hogy a két dolog hasonló mozgatórugókkal bír.

Mindez tovább erősíti azon érveket, mely szerint a jövőbeli aggregált folyamatok becslésére a migrációs hajlandóságra vonatkozó adatok természetesen nem alkalmasak.

\footnotetext{
${ }^{89}$ Megjegyzendő, a szelekciós vizsgálatok szempontjából elsősorban nem az érdekes, hogy a szándékot hányan valósítják meg, hanem, hogy jellemzően tényleg inkább azok vándorolnak-e el, akik azt korábban tervezték.
} 
Alátámasztják ugyanakkor azt az állítást is, hogy a migrációs szándék megfogalmazódása a kivándorlás kvázi-szükséges „elöszobájának” tekinthető, így az előbbit befolyásoló tényezők nagy valószínüséggel utóbbira is érdemi hatással vannak. Kiegészítve mindezt azon itt tárgyalt pozitív vonásokkal, amelyekkel a migrációs potenciálra vonatkozó adatok rendelkeznek (szemben a tényleges migrációs adatokkal, amelyek viszont nem), összefoglalóan elmondhatjuk, hogy használatuk megalapozott migrációs elméletünk empirikus teszteléséhez.

\subsection{Felhasznált adatok}

Az előző alfejezetben leírtak tükrében modellünk teszteléséhez migrációs hajlandóságra vonatkozó adatokat használunk, amelyeket Eurobarometer felmérések eredményeiböl nyertünk. Az Eurobarometer egy olyan felmérés-sorozat, amely immáron több, mint négy évtizedes viszonylatban készít kérdőíves vizsgálatot az európai integráció tagállamaiban. A felmérés során tagállamonként körülbelül ezer-ezer személyes megkérdezésen alapuló kérdőívezést folytatnak le reprezentatív mintavétellel és azonos módszertannal a tagállamok saját hivatalos nyelvein. A kérdőívek tematikája általában az európai integrációval kapcsolatos attitüdökre fókuszál, emellett azonban rendre tartalmaznak tematikus kérdésblokkokat más, aktuális ügyekre, jelenségekre vonatkozóan. Ennek eredményeként egy olyan európai szintü, tagállamonként reprezentatív, térbeli - és bizonyos esetekben időbeli - összehasonlításra alkalmas, mikroszintű adatokat tároló, megbízható adathalmaz áll a kutatók rendelkezésére, amely a társadalomtudományok számos területén jól használható. A felmérések egyéni szintű adatai a Leibniz-Institut für Sozialwissenschaften Data Catalogue DBK adatbankjában érhetők el, s használhatók fel onnan kutatási célra. Az adatbank részletes dokumentációt is közöl a felmérések módszertani hátteréről, s a felmérésekhez tartozó különböző nyelvü kérdőívek, kérdezési útmutatók és a hozzájuk tartozó codebookok is letölthetők belöle. Jelen disszertáció elemzésének elkészítéséhez is ezen adatbank szolgált forrásként.

A 2004 és 2016 közötti felmérések áttekintése során hét standard és kettő ifjúsági Eurobarometert találtunk, amely tartalmazott migrációs hajlandóságra vonatkozó adatokat. Ezek - az Eurobarometer felmérések számozásait használva - a következők voltak: 64.1 2005-böl, 67.1 2007-böl, 70.1. 2008-ból, 72.5 2009-böl, 73.3 2010-ből, 75.1 2011-böl, 79.2 2013-ból, illetve a „European Youth” elnevezésü Flash Eurobarometer 395 2014-ből, valamint a 16-30 évesek mintáján dolgozó 85.1OVR 2016-ból. A felsoroltak közül kettő bizonyult alkalmasnak arra, hogy segítségükkel teszteljük jelen 
disszertáció hipotéziseit: a Data Catalogue DBK megnevezését használva ezek a „ZA4819: Eurobarometer 70.1 (Oct-Nov 2008)” és a „ZA5233: Eurobarometer 73.3 (Mar-Apr 2010)" felmérések voltak. A továbbiakban előbbit 2008-as, utóbbit pedig 2010es Eurobarometer felmérésnek nevezzük, s rendre a European Commission (2012c) és European Commission (2012d) hivatkozásokkal jelöljük őket.

A felhasználhatóság feltétele az volt, hogy a surveyek a migrációs hajlandóságra és a kontrollváltozóként használható szokásos demográfiai ismérvekre vonatkozó kérdéseken túl további olyan kérdéseket is tartalmazzanak, amelyek válaszai disszertációnk hipotéziseinek teszteléséhez szükséges (proxy) változóként használhatók. Tehát tartalmaznia kellett többek között az intézményekbe vetett bizalomra, a specifikus beruházások meglétére, a tranzakciós költségek mértékére, valamint a hüségre vonatkozó információkat. Ilyen attribútumokkal - amelyben a nevesített információk ráadásul megbízhatóan az elvándorlást megelőző időszakra vonatkoztak volna - egy tényleges migrációra vonatkozó adatbázis aligha rendelkezett volna. Mindazonáltal a kiválasztott Eurobarometer felmérések egyike sem tartalmazott valamennyi fontos tényezőre vonatkozó proxyt, így hipotéziseinket a 2008-as és 2010-es adat szetten külön tudjuk tesztelni. Ez kettő, egymástól független keresztmetszeti vizsgálatot jelent majd (a változók jelentős részének körében persze nagymértékü lesz az átfedés). Az adat szettek összekapcsolásával panel adatbázis létrehozására ugyanis nem volt lehetőség. Ennek oka, hogy a lekérdezések különböző hullámaiban sem a megkérdezettek köre, sem a migrációs potenciál mérésének módja nem volt azonos. A fő problémát utóbbi jelentette: a válaszadók migrációs potenciáljára ugyanis az Eurobarometer az egyes hullámokban a lehető legkülönbözőbb módokon kérdezett rá. A kérdés tulajdonképpen mind a szóhasználatban, mind a migráció céljában, mind a belátható időtávban rendre változott, s csak a 2007-es és 2008-as felmérések és a két ifjúsági Eurobarometer voltak azok, amelyek páronként ugyanazt a megfogalmazást használták. Erről az 3.1. melléklet ad áttekintést.

Az általunk felhasznált két kérdöívet az EU mind az akkori huszonhét tagállamában reprezentatív mintán vették fel. A 2008-as felmérésben összesen $26.618^{90}$, míg a 2010-esben 26.602 európai polgár válaszait rögzítették. Ezen mintákon további szürést nem végeztünk. Bár szólhattak volna érvek bizonyos, migrációra kevéssé képes

\footnotetext{
${ }^{90}$ A teljes felmérésben valójában többen vettek részt, hiszen a kérdőívet nem csak EU-tagállamokban, így Horvátországban, Macedóniában, Törökországban és Ciprus török részén is rögzítették. Mivel azonban itt a migrációs szándékra vonatkozó kérdéseket nem tették fel, ezen elemeket kiszürtűk a vizsgálatunkból.
} 
vagy hajlandó csoportok (például idősek, iskolázatlanok) kiszürése, s ezáltal egy „releváns népességre” vonatkozó minta kialakítása mellett (Sik, 2018, 111. o.), ez ellentétben állt volna jelen disszertáció céljával. Elméleti modellünkkel ugyanis arra is választ kívántunk adni, hogy mi teszi „irrelevánssá” e csoportokat a migráció szempontjából (például a specifikus beruházások vagy a tranzakciós költségek magas volumene), s mindezt empirikusan is tesztelni kívántuk. Így az említett csoportok kihagyása helyett modellünk változóival kontrollálunk ezen szermélyek bizonyos jellemzőire.

A válaszadók pontos számáról - tagállami szintủ bontásban - a 3.2. melléklet nyújt áttekintést. A továbbiakban ezen széles fókuszú, nagy minták felhasználásával kívánjuk vizsgálni, hogy milyen tényezők befolyásolják az emberek elvándorlási hajlandóságát.

Az adatbázisok az előző, illetve jelen alfejezetben leírtak alapján tehát alkalmasak modellünk tesztelésére. Ráadásul, lévén, hogy EU-tagállami mintákról van szó, további jó tulajdonságokkal is rendelkeznek. Mivel az Európai Unión belül a személyek szabadon áramolhatnak, s a régió fejlettségéböl fakadóan a mobilitási költségek is alacsonyabbak, mint a fejlődő világ országaiban, ezért a kivándorlási szándékok és a tényleges migráció között szorosabb kapcsolatot feltételezhetünk, mint átlagosan a globális szinten. Itt ugyanis az említett tényezők miatt kevesebb olyan tényező jöhet közbe a migrációs szándék megfogalmazódása után, amelyek meghiúsítják a tervek megvalósítását (vö. a 3.1. alfejezetben leírtakkal), mint a szigorú bevándorláspolitikai rezsimek és az infokommunikációs technológia vívmányaitól elzárt területek esetén. 


\section{MÓDSZERTAN}

Jelen fejezetben azt mutatjuk be, hogy milyen módszerrel kívánjuk tesztelni hipotéziseinket. Először a 4.1. alfejezetben - a vizsgálati cél és a rendelkezésre álló adatok tükrében - a megfelelő modellválasztás kérdését tárgyaljuk, amit az empirikus modell 2.4. alfejezetben felvázoltak alapján történő felírása követ. Ezután a 4.2. és 4.3. alfejezetekben a két vizsgálatunk modellspecifikációjának bemutatására, változóik konceptualizációjára, operacionalizációjára és főbb leíró statisztikáik ismertetésére kerül sor.

\subsection{Empirikus modell}

Disszertációnk elméleti modelljében az egyén döntésének két kimenetele lehet: az elvándorlás és a maradás. A 2. fejezetben elméleti megfontolások alapján azt vázoltuk fel, hogy mik növelhetik előbbi bekövetkezésének az esélyét, a (12) és (13) kifejezésekben pedig formálisan is felírtuk az erre vonatkozó valószínűséget. A következőkben erre kívánunk empirikus becsléseket készíteni, s a 3.2. alfejezetben bemutatott adat szettek segítségével regressziós modellekkel megvizsgálni, hogy mely tényezőknek lehet valóban szignifikáns hatása a migrációs döntésre.

Mivel diszkrét kimenetek bekövetkezési valószínüségét becsüljük, empirikus modellünk eredményváltozója is kvalitatív, bináris változó lesz. Ilyen esetben azonban nem a standard OLS technika a legalkalmasabb a becslés készítésére: bár használható, alkalmazása során több probléma is felléphet. Ezeket, illetve az adekvát alternatívaként használt logit modellek jellemzőit a következőkben Cameron \& Trivedi (2009), Pedace (2013), Ramanathan (2003) és Wooldridge (2016) alapján foglalunk össze.

Amennyiben egy dichotóm eredményváltozójú modellt OLS technikával kívánunk becsülni, azt lineáris valószínüségi modellnek (linear probability model, a továbbiakban LPM) nevezzük. LPM alkalmazásakor ugyanakkor a hibatagok nem lesznek normális eloszlásúak, s a varianciájuk sem konstans, azaz a heteroszkedaszticitás problémája lép fel, így ezen becslések nem tekinthetők hatásosnak. A nem-normalitás persze a centrális határeloszlás tétele alapján leginkább csak kis minták esetén okoz problémát, a heteroszkedaszticitás jelensége pedig megfelelő módszerekkel kezelhető. Ezért a legfőbb gondot az LPM alkalmazásakor inkább az jelenti, hogy az általa becsült valószínűségek nem szükségszerűen 0 és 1 közé fognak esni. Ez pedig mind a 
matematika, mind a hétköznapi gondolkodás számára értelmetlen és értelmezhetetlen eredménynek tekinthető.

Ezen hátulütők logisztikus regresszió (logit modell) alkalmazásával küszöbölhetők ki, amely az általa becsült függvényformának köszönhetően szükségszerủen a 0 és az 1 értékek közé szorítja be a becsült valószínűségeket. A logit modell ugyanis a logisztikus eloszlás eloszlásfüggvényével váltja fel az OLS lineáris függvényét, így az esemény bekövetkezését a (14) kifejezésben szereplő függvényforma segítségével becsüli. Ehhez maximum likelihood technikát használ.

$$
\operatorname{Pr}(m i g r=1 \mid \boldsymbol{x})=F\left(\beta_{0}+\beta_{1} x_{1}+\cdots+\beta_{m} x_{m}\right)=F\left(\beta_{0}+\boldsymbol{\beta} \boldsymbol{x}\right)=\frac{e^{\beta_{0}+\boldsymbol{\beta} x}}{1+e^{\beta_{0}+\boldsymbol{\beta} \boldsymbol{x}}},
$$

ahol $F$ a 0 és 1 közötti értékkészlettel rendelkezö függvényformát jelöli, az $x$-ek a modell $m$ darab változóját, a $\beta$-k a hozzájuk tartozó együtthatókat jelölik, $\boldsymbol{x}$ és $\boldsymbol{\beta}$ pedig rendre ezek vektorai.

A (12) és (13) kifejezések által felírt valószínűség becslésére disszertációnkban ilyen, logit modellt használunk. Mivel azonban a logit modellek koefficienseinek nagysága nem értelmezhető közvetlenül, az eredmények diszkussziójakor a modellek marginális hatásait közöljük. Ezek a parciális hatások azonban, ellentétben az LPM-mel, nem szükségszerüen konstansok, ezért ennél a lépésnél - a közgazdasági alkalmazásokban szokásosnak tekintett módon - az átlagban vett marginális hatásokat fogjuk becsülni. A heteroszkedaszticitás problémájának kezelése érdekében az empirikus modellekben a White-féle heteroszkedaszticitás-konzisztens standard hibákkal (robusztus standard hibákkal) dolgozunk.

Disszertációnk második vizsgálatában emellett egy rendezett (ordered) logit modellt is becsülni fogunk. Ezen empirikus modell alkalmazására akkor van lehetőség, ha a becslésben használt eredményváltozó nem csak kettő, hanem többféle értéket is felvesz, s ezeknek az egymáshoz viszonyított sorrendisége is értelmezhető. Mint azt a 4.3. alfejezetben részletesen is bemutatjuk, a második vizsgálatban használt adatszett a jövőbeni elvándorlás valószínűségét egy négyfokozatú skálán méri, ami így lehetővé teszi, hogy az egyszerü logisztikus regressziók eredményeinek robusztusságát egy rendezett logit modell segítségével is teszteljük.

Modelljeink diagnosztikai, valamint illeszkedési vizsgálatait Cameron \& Trivedi (2009), Neyman (2018), Pedace (2013), Tőkés (2017), Wooldridge (2016) ajánlásai alapján végezzük el. A kiindulópontot ebben a logit modellekhez tartozó pszeudo Rnégyzet mutatók jelentik, amelyek értéke ugyan általában alacsony, de - az OLS 
technikával becsült modellek R-négyzet mutatóhoz „hasonlóan” - egyfajta mérceként szolgálnak az illeszkedés vizsgálatához. Disszertációnkban ezek közül a McFadden-féle pszeudo R-négyzet mutatót közöljük. Az illeszkedés tesztelésére emellett egy olyan mutatót is használunk, amely azt adja meg, hogy a modell (mintán belül) milyen arányban tudja helyesen megbecsülni az eredményváltozó kimenetelét. Mivel azonban az eredményváltozó $\widehat{m i g r}$-pal jelölt becsült értékei - ellentétben a valódiakkal - nem kizárólag a 0 és 1 értékeket veszik fel, hanem valamilyen közéjük eső valós számot, ezért a helyes becslés fogalmának meghatározásához egy cut-off pontot kell meghatároznunk. Ez vizsgálatunkban - a szokásos gyakorlatoknak megfelelően - a 0,5 lesz. Ha $\widehat{m l g r} \geq$ 0,5 a minta valamely elemére, úgy azt elvándorlónak kategorizáljuk, $\widehat{\operatorname{mlgr}}<0,5$ esetén pedig maradónak. A kategorizálást követő összegzéssel így arra kapunk egy arányszámot, hogy a modell hány százalékban becsülte meg helyesen az eredményváltozó kimenetelét a minta elemeire. Mindazonáltal hangsúlyozzuk: noha ez az eljárás bevett módszernek számít a logit modellek esetén, jelen vizsgálat célja nem a predikció. Ez összhangban van Wooldridge (2016, 531. o.) álláspontjával is, mely szerint a logit modelleknél „az illeszkedés általában kevésbé fontos, mint az, hogy megpróbáljunk meggyőző eredményekre jutni a változók ceteris paribus hatásaival kapcsolatban”. Ennek megfelelően disszertációnkban is az számít elsődleges szempontnak, hogy a mintán beigazolódnak-e a változók előjeleire és szignifikanciájára vonatkozó várakozásaink, nem pedig a modell egészének illeszkedése vagy az, hogy egyénre lebontva milyen előrejelzés adható az empirikus modell segítségével.

A modellek ,jóságának” tesztelésére további próbákat is használunk. Minden esetben közöljük a likelihood ratio khí négyzet próba (G teszt) eredményeit, amely azon nullhipotézist teszteli, mely szerint egy egyszerü konstansból álló modell a tényleges specifikációnál jobb becslést adna az eredményváltozóra vonatkozóan. Emellett a Hosmer-Lemeshow specifikációs tesztet is alkalmazni fogjuk, amely az illeszkedést úgy vizsgálja, hogy a függő változó mintabeli gyakoriságát a megfigyelések kvartilisek szerinti alcsoportjain belüli illesztett valószínüségekkel hasonlítja össze. Ennek nullhipotézise a kettő egyenlőségére vonatkozik, így a próbák lefolytatásakor az inszignifikáns p-értékek utalnak a jó illeszkedésre. A különböző specifikációk közötti választáskor a fenti mutatókon túl a link teszt eredményeit is felhasználjuk. Ez az eljárás az eredményváltozót annak modellbeli becsült értékein, illetve utóbbinak a négyzetén regresszálja az eredeti független változók elhagyásával. Adekvát modellek esetén a 
becsült értékek változójának szignifikánsnak, míg azok négyzetének inszignifikánsnak kell bizonyulnia a link teszt során.

A multikollinearitás létét a VIF (variance inflation factor) mutató segítségével teszteljük, amely a lineáris asszociációt méri egy adott magyarázó változó, s a többi független változó között. Noha egzakt módon nem határozható meg, hogy a VIF mutató nagysága mikor számít kritikusnak, Pedace (2013) és Tőkés (2017) szerint a 10 feletti értékek utalnak erős multikollinearitásra. Ennek megfelelően disszertációnkban is ezt tekintjük küszöbnek. Így a VIF mutató segítségével vizsgáljuk ugyan a multikollineritást, ám annak esetleges megjelenését eredendően nem tekintjük problémának. A multikollinearitás léte ugyanis nem vezet torzított becsléshez, csak a változók standard hibáinak növekedését eredményezheti, ami a változók szignifikanciájára van hatással. Így az egymással erősen korreláló magyarázó változók együttes szerepeltetése elsősorban akkor problémás, ha ez inszignifikáns vagy értelmetlen elöjelü együtthatókhoz vezet, illetve ha azok szignifikanciája érzékeny a specifikációk változtatására (Pedace, 2013).

Elméleti modellünket a fentiek szerinti logit modellekkel a következö alfejezetekben bemutatásra kerülő változókon teszteljük. A modellek robusztusságának ellenőrzése érdekében a következő alfejezetekben felvázolandó specifikációkat több módon is változtatjuk majd, s a becsléseket különböző almintákra is elvégezzük. Az újabb változók bevonásakor a lépés indokoltságának vizsgálatára likelihood ratio teszteket végzünk. Mindehhez a STATA ökonometriai szoftvert használjuk.

\subsection{Konceptualizáció és operacionalizáció: első vizsgálat}

Az általunk használt 2008-as Eurobarometer felmérés kérdőívének (jelen alfejezetben a továbbiakban: a kérdőív) egyik tematikus kérdésblokkja a nemzeti és az uniós intézményekkel, a tagállamok EU-n belüli helyzetével és jövőjével kapcsolatos attitüdökre, véleményekre fókuszált. Emellett a survey részletesen érintette a nemzetközi migráció kérdését, s kitért a válaszadónak mind a múltbéli tapasztalataira, mind a jövőbeli terveire (European Commission, 2012c). E kettő téma együttes jelenléte teszi lehetővé, hogy az adatbázis segítségével tesztelni tudjuk az intézményi bizalom és a kivándorlás közötti kapcsolatra vonatkozó feltevéseinket.

A modell eredményváltozóját a felmérés migrációs szándékra vonatkozó kérdése, s az arra adott válaszok alapján képeztük. Ehhez a kérdöív QF4 és QF5 kérdéseit használtuk fel, amelyek pontos szövegezéssel, illetve a rájuk adható lehetséges válaszokkal az 4.1. táblázatban olvashatók. A migr ${ }^{2008}$ kétértékü változó 
megkonstruálása során azon válaszadókat definiáltuk potenciális migránsként, akik a QF4 kérdésre igennel feleltek, ezt követően pedig QF5 kérdésben az EU-n belüli vagy az EUn kívüli másik országba történő költözési szándékra vonatkozóan adtak pozitív választ. Esetükben migr $^{2008}=1$, míg a QF4 kérdésre nemleges és a QF5 kérdésre az imént megnevezettektől eltérő választ adók esetében $m i g r^{2008}=0 . \quad$ Így az eredményváltozóban foglaltak megegyeznek disszertációnk Bevezetésben definiált migráció-fogalmával: a felhasznált kérdések önkéntes, országhatáron átnyúló vándorlásra vonatkoznak, s bár a migráció időtartamára vagy annak konkrét céljára vonatkozó explicit információ nem jelenik meg bennük (az egy éven túli időtartam a későbbi, tisztított migrációs potenciál mutató képzéséhez használjuk fel), a költözés szó mindenképp tartósabb, letelepedéssel is járó mozzanatra utal.

\section{1. táblázat \\ Az eredményváltozó képzéséhez felhasznált kérdések a 2008-as Eurobarometer felmérésből}

QF4: Szándékozik egyáltalán elköltözni a

\begin{tabular}{ll} 
& következő öt évben? \\
\hline Igen & \\
Nem & \\
NT/NV
\end{tabular}

Forrás: European Commission (2012c)

\begin{tabular}{l} 
QF5: És szándékozik ...? \\
\hline Városon / falun belül költözni \\
Másik városba / faluba költözni régión belül \\
Másik régióba költözni országon belül \\
Másik, EU-n belüli országba költözni \\
Másik, EU-n kívüli országba költözni \\
NT/NV
\end{tabular}

Mint látható, szóhasználatából fakadóan a kérdés egyfajta erősebb migrációs potenciálra céloz: szándékra kérdez rá, nem hajlandóságra vagy elképzelhető lehetőségre. Ebből fakadóan a potenciális migránsok aránya is alacsony a mintában: a Q4 kérdésre érvényes választ adóknak csak 4,24 százaléka sorolható be ebbe a kategóriába. Az elvándorolni szándékozók tagállamonkénti arányairól a 4.1. melléklet ad áttekintést.

Noha megfogalmazásából eredően a fenti nyers migrációs potenciál is konkrétabb szándékra utalt, s az e kategóriába esők is meglehetősen kis százalékát teszik ki a teljes mintának, az eredmények robusztusságának tesztelése érdekében célszerünek látjuk egy tmigr ${ }^{2008}$ tisztított migrációs potenciál változó konstruálását is. Ehhez három szürőfeltételt határoztunk meg: i) a QF6 kérdésben válaszadó tudjon megnevezni legalább egy potenciális célországot, ahová menni szándékozik; ii) a tartózkodási időre vonatkozó 
QF7 kérdésre adott válaszként legalább néhány évet jelöljön meg91; iii) a QF8 kérdésre válaszul meg tudjon jelölni legalább egy olyan felkészülési lépést, amelyet a külföldre történő költözéshez kapcsolódóan tett (például információkat szerzett a költözésröl, keresett szállást stb.). Ezzel a kivándorolni szándékozóknak több, mint felét kiszürtük, s a válaszadóknak mintegy 1,86 százaléka maradt, aki befért az új változó jellemzői alá. Őket tisztított migrációs potenciállal rendelkezőknek nevezzük. Róluk azonban joggal feltételezhetjük, hogy komoly szándékokkal rendelkeznek, s hogy az adatfelvétel után érdemi valószínűséggel valósíthatták meg a tartósabb időre szóló elvándorlást. Tagállamonkénti arányukat a 4.2. melléklet szemlélteti.

Jelen vizsgálat fókuszában az intézményekbe vetett bizalom áll. Erre a felmérés közvetlenül rákérdez a QA12-es kérdésben: „Most azt szeretném megkérdezni Öntől, hogy mennyire bízik Ön a következö intézményekben? Kérem a felsorolt intézmények mindegyikéről mondja meg, hogy inkább bízik bennük, vagy inkább nem bízik bennük." A felsorolásban az ,igazságszolgáltatás/[válaszadó országa szerinti] jogrendszer”, a „politikai pártok”, a „regionális vagy helyi hatóságok”, „a [válaszadó országa szerinti] kormány”, „a [válaszadó országa szerinti] parlament”, ,az Európai Unió”, ,az ENSZ” és a „NATO” szerepeltek, a lehetséges válaszok pedig az „inkább bízik”, „inkább nem bízik” és a „NT/NV/nincs véleménye” opciók voltak. Az egyes alkérdések közül elsősorban az igazságszolgáltatásra/jogrendszerre vonatkozó bizalommal kapcsolatos válaszokat használjuk az elméleti modellünkben definiált intézményi bizalom proxyjaként. Ezekből a Bizalom_jog változót képeztük, amelynél az 1 érték a bizalom meglétére, a 0 pedig annak hiányára utal. Emellett konstruáltunk egy, az ország intézményrendszerével szembeni általános bizalomszintet leíró Bizalom_általános mutatót is, amelyet a belföldi entitásokkal (igazságszolgáltatás/jogrendszer, politikai pártok, regionális vagy helyi hatóságok, kormány, parlament) kapcsolatos alkérdésekre adott válaszok fentiek szerinti értékének átlagolása ad meg. ${ }^{92}$ Elméleti modellünk,

\footnotetext{
${ }^{91}$ Ezzel a kritériummal a „néhány hétig”, „néhány hónapig” és a „NT/NV” válaszok adóit szürtük ki.

92 A QA12 kérdésben szereplő entitások többsége nem feleltethető meg a 2.2. alfejezetben bemutatott intézmény-definíciónknak, hiszen az alapján inkább szervezetekről van szó. Emiatt az intézményi bizalom proxyjaként elsősorban az igazszágszolgáltatással/jogrendszerrel szembeni bizalmat használjuk. Tekintve azonban, hogy a további felsorolt szervezetek elsőszámú alakítói, végrehajtói és kikényszerítői az intézményeknek, a beléjük vetett bizalom is jó proxyként szolgálhat az intézményi bizalom mérésére. Annál is inkább, mivel a hétköznapi ember számára ezek a kérdések jól megfoghatónak és könnyen értelmezhetőnek tekinthetők, míg ugyanez nem lett volna elmondható a kérdésről, ha az arra irányult volna, hogy a válaszadó bízik-e abban, hogy az intézmények betöltik a szerepüket. Ezen szempontok így együttesen szólnak a Bizalom_általános változó modellbeli létjogosultsága és indokoltsága mellett.
} 
valamint $H 1$ hipotézisünk alapján azt várjuk, hogy azok, akik inkább bíznak az intézményekben, ceteris paribus kevésbé hajlamosak az elvándorlásra. ${ }^{93}$

Nem csak az országok formális intézményrendszere, hanem a társadalmak informális intézményei közötti meghúzódó különbségek is befolyásolhatják a migrációs szándékot. Ezt egy, a QF12 kérdés esetén megjelölhető válasz segítségével teszteljük. A kérdés arra irányult, hogy egy másik EU-tagállamba költözés esetén melyek lennének a legnagyobb nehézségek, amelyekkel az egyénnek szembe kellene néznie, s a lehetséges válaszok között az „Egy más kultúrához való alkalmazkodás” alternatíva is szerepelt. Ebből az Intézmény_informális dummy változót képeztük annak függvényében, hogy a válaszadó megjelölte-e az említett opciót. Elméleti modellünk alapján az eltérő informális intézményrendszerhez való alkalmazkodás teherként jelenhet meg az elvándorló számára, amitől így a kivándorlási kedv csökkentését várjuk. Így, ha a változó negatív elöjellel jelenik meg a becslésben, az a H1 hipotézisünkhöz nyújt visszacsatolást.

Amint azt a 2.3.2. alfejezetben bemutattuk, a kivándorlás tranzakciós költségét a migrációs hálózat megléte tudja csökkenteni. Ennek egyik forrása a korábbi migrációs tapasztalat. Mivel a survey a QF1 kérdésben rákérdez arra, hogy a válaszadó élt-e korábban külföldön, ezért ezt a Hálózat_tapasztalat dummy változóként szerepeltetni tudjuk a modellünkben a H2 hipotézis teszteléséhez. A kérdőívben emellett szerepelt olyan kérdés is, amely a potenciális célországban fellelhető barátok, családtagok meglétére irányult, ezt azonban csak a kivándorolni szándékozóknak tették fel. Így egy ebből képzett változó szerepeltetése a kivándorlás szelekciós tényezői között elvi szempontból hibás lenne, technikai szempontból pedig akadályokba ütközne.

A tranzakciós költségek mértékét a hálózatok mellett - mint azt tárgyaltuk - az infokommunikációs technológiához való hozzáférés és az idegennyelv-ismeret is befolyásolni tudja. Előbbi ellenőrzéséhez a survey D46 kérdését használjuk fel, amely a válaszadó háztartásában fellelhető javak feltérképezésére irányul. Ezek között szerepelt az otthoni internethozzáférés, amelynek válaszait az Internet dummyn keresztül építjük be modellünkbe. Nyelvtudásra vonatkozó közvetlen kérdés az Eurobarometer ezen

\footnotetext{
${ }^{93}$ Az intézményi minőség „mérésére” választott proxynk kapcsán felmerülhet a kérdés, hogy probléma-e, ha a származási országok intézményrendszerét egy szubjektív mutatóval ítéljük meg ahelyett, hogy valamilyen indikátort használnánk erre. Elméleti modellünkből azonban pontosan ez, az egyéni értékelést megtestesítő változó használata következik. Világos ugyanis, hogy amikor az egyén az elvándorlás kapcsán mérlegeli jövője kiszámíthatóságát, nem valamely szervezet „mesterséges” indikátora, hanem személyes tapasztalata, benyomása alapján dönt erről. Ezáltal ráadásul az intézményi müködés megítélésében országon belül egyéni szinten is tapasztalható variancia, míg egy külső indikátor használata esetén csak egy országszintü ,fix hatást” építenénk be a modellbe.
} 
hullámában nem szerepelt, azonban megtalálható benne két olyan tétel, amelynek segítségével becsülni tudjuk azt. A külföldre költözést elbizonytalanító tényezőket vizsgáló QF11 kérdésre adható válaszok között lehetőség volt megjelölni a „meg kellene tanulni egy új nyelvet” opciót, míg a már hivatkozott QF12 kérdésnél a „nyelvi ismeretek hiánya" is megjelölhető volt. Az e két kérdésekre adott válaszokat - fenntartásokkal ugyan, de - értelmezhetjük a nyelvtudás proxy-jaként. A belölük képzett, rendre Nyelv1 és Nyelv2 dummy változók így alsó becsléseket képesek adni az idegen nyelvet beszélök számára vonatkozóan: akik megjelölték az említett válaszlehetőséget, ők saját belátásuk szerint nem rendelkeznek a külföldi élethez megfelelő idegennyelv-tudással, abból azonban, hogy valaki nem jelölte meg valamelyiket, még nem következik, hogy beszél valamilyen idegennyelvet. Így a változók hatását - amelyeknél a 0 érték a nyelvtudás hiányát, az 1 pedig az esetleges meglétét jelöli - teszteljük ugyan a kivándorlási kedv alakítására, azonban nem minden modellspecifikációban, $\mathrm{s}$ a rájuk vonatkozó eredményeket is óvatosan kezeljük. H2 hipotézisünk alapján e három dummy mindegyikét negatív előjellel várjuk a becslésbe.

Az idegennyelv-tudás emellett a humántőke országspecifikusságának is egyfajta indikátora. Így az elméleti modellünkben foglaltak alapján a Nyelv1 és Nyelv2 változókat $\mathrm{H} 3$ hipotézisünk alapján is negatív előjellel várjuk a regressziókban.

A 2.3.4. alfejezetben bemutattuk, hogy a családalapítás az egyén szempontjából egyfajta specifikus beruházásként értelmezhetö, ami idioszinkratikus kapcsolatokat hoz létre. Ennek indikátora a családi állapot, amelyre a kérdőív D7 kérdése alapján a következő dummy változókat vezetjük be: Házas, Partnerrel élö, Egyedülálló, Elvált és Özvegy. A Házas változót a házas, illetve újraházasodott válaszok, az Egyedülálló változót a „hajadon/nőtlen, sosem élt partnerrel” és a „hajadon/nőtlen, régebben partnerrel élt együtt, de most egyedül van" válaszok, az Elvált változót pedig az „elvált” és „Házas, de külön élő” válaszok összevonásával képeztük. Az egyéb spontán válaszok esetén hiányzó értékkel dolgozunk. A saját háztartásban élő 15 év alatti gyermekek számát a Gyermek változó jelöli, amelyet a D40b és D40c kérdésekre adott válaszok segítségével állítottunk elő. A családi kapcsolatok megléte ráadásul más szempontból is fontos: mind Becker (1974), mind Simon (1993) azt állítja, hogy szociobiológiai okokból eredően a család jelenti az alturista kapcsolatok bázisát, amely ugyancsak ellenösztönzője lehet a kivándorlásnak (utóbbiak otthonmaradása esetén, a 2.3.5. allfejezetben megfogalmazott bizonyos feltételek mentén). Mindezek tükrében azt 
várjuk, hogy a nagyobb és intézményesített családdal rendelkezők ceteris paribus kisebb hajlandóságot mutatnak az elvándorlásra. Ez elsősorban H3 hipotézisünkhöz nyújt majd visszacsatolást, de információval szolgál H4 érvényességére vonatkozóan is.

A családi altruizmuson keresztül jelentkező lelki költségek szerepének tesztelésére a fentieken túl egy, a már hivatkozott QF11 kérdésre adható válasz nyújt lehetőséget: a válaszadónak ugyanis lehetősége volt a „Közvetlen kapcsolat hiánya a családdal vagy a barátokkal" opciót is megjelölni. Ebből a Lelki költség változót képeztük, amelytől H4 hipotézis alapján azt várjuk, hogy csökkenti a kivándorlási kedvet.

Amint azt bemutattuk, a saját ingatlan tulajdonlása helyspecifikus beruházásnak tekinthető. Erre vonatkozó információt szintén a D46 kérdés alapján nyerhetünk, amely a háztartásban megtalálható javak között megjelölhető opcióként említi az „Egy olyan lakás vagy ház, amelyet már teljes mértékben kifizetett” és az „Egy olyan lakás vagy ház, amelyért még fizeti a részleteket" válaszokat. Ezekből az Ingatlan dummy változót képeztük, amely akkor veszi fel az 1 értéket, ha a válaszadó a fenti opciók valamelyikét megjelölte. E változót a H3 hipotézis alapján negatív előjellel várjuk modellünkbe.

A fentieken túl az egyén további egyedi, demográfiai jellemzőire is kontrollálunk. Ezek közé tartozik a korára utaló, D11 kérdés alapján kreált Kor változó, amely az 1.1.3. alfejezetben leírtak alapján standard befolyásoló tényezője a migrációnak, s ezáltal az azt tesztelő empirikus vizsgálatoknak is. Emellett megjegyzendő, hogy Lowe \& Ritchey (1973) eredményei szerint az idősebb emberek általában több altruista attitüdöt mutatnak, mint a fiatalok. Noha vélhetően nem ez a fő hatásmechanizmus, de a kor és az altruizmus megjelenése (vagy erősödése) között feltételezett korreláció is magyarázat lehet arra, hogy a változót negatív előjellel várjuk a modellbe, ami így a $\mathrm{H} 4$ hipotézishez is némi visszacsatolást nyújt. Továbbá Furubotn \& Richter (2005), illetve Mike (2008; 2009; 2012) alapján azt is megállapítottuk, hogy az egyén korának elöre haladtával egyre több specifikus beruházást eszközöl, így a változó a H3 hipotézishez is adalékkal szolgál.

A válaszadó nemére a D10 kérdés vonatkozott, ezt a Nem dummyval építjük be a modellbe, amely férfiak esetén 1 , nők esetén 0 értéket vesz fel. Az irodalmi áttekintésben leírtak alapján a férfiaktól várunk nagyobb migrációs hajlandóságot. A válaszadók munkaerőpiaci helyzetéről a D15a kérdés nyújt információt. Ezekből ugyancsak dummy változókat képeztünk, úgy, hogy az 1 és 3 kódolású válaszokat a Munkanélküli, a 2 kódolásúakat a Tanuló, a 4 kódolásuakat a Nyugdíjas, az 5-től 9ig terjedő kódolásúakat az Önfoglalkoztató, a 10-től 14-ig terjedő kódolásúakat a 
Foglalkoztatott_fehérgalléros, a 15-től 18-ig terjedőeket pedig a Foglalkoztatott_kékgalléros változókban rögzítettük. A válaszadó lakhelyének típusára vonatkozó információt a D25 kérdés válaszai alapján nyertünk, amelyekből rendre a Falu, Kisváros és Nagyváros dummy változókat képeztük. Elméleti modellünk alapján mind a munkaerőpiaci státusz, mind a településnagyság visszacsatolást nyújt a specifikusság csatornáján keresztül $\mathrm{H} 3$ hipotézisünkhöz. A nagyvárosok lakóitól emellett az alacsonyabb tranzakciós költségek miatt a H2 hipotézis alapján is nagyobb migrációs hajlandóságot várunk. A válaszadók konkrét iskolai végzettségére a kérdőív nem kérdez rá, de a D8 kérdésben arra igen, hogy hány éves korukban fejezték be a nappali iskolát. Az erre adott válaszok az Iskola változóval kerülnek be a modellbe. Azok esetében, akik az adatfelvétel időpontjában még tanultak, ezt a számot a korukkal helyettesítettük, azokhoz pedig, akik válaszuk szerint nem vettek részt soha formális oktatásban, a 0 értéket rendeltük. A változó így jó proxyként szolgál az egyén képzettségének indikátoraként. Az 1. és 2. fejezetekben leírtak alapján azt várjuk, hogy a magasabb képzettséggel, ezáltal jobb humántőkével rendelkező személyek nagyobb valószínüséggel vándorolnak külföldre.

Mindezen túl, összhangban viselkedési előfeltevéseinkkel és az irodalmi áttekintésben foglaltakkal, egyes specifikációkban kontrollálunk az egyén elégedettségére is. Ezt a kérdőív QA3 kérdése alapján tesszük meg az Elégedetlenség változó bevezetésével, amelyben a válaszadó egy négyfokozatú skálán (ahol a kisebb érték a pozitív, míg a nagyobb a negatív válaszokra utalt) nyilatkozhatott az életével való elégedettségéről.

Első vizsgálatunk modelljébe tehát - amelyet a 2008-as Eurobarometer felmérés adatain végzünk - az itt tárgyalt változókat vonjuk be. Logisztikus regressziók segítségével különböző specifikációkat (részletesen lásd az 5.1. alfejezetben) fogunk becsülni annak érdekében, hogy a legjobb modellt találjuk meg, amely egyben robusztus eredményeket is mutat. Így a különböző specifikációkban különböző magyarázó változókombinációkat használunk, egyesekben pedig ország dummykat is használunk az országspecifikus tényezők megragadására.

\subsection{Konceptualizáció és operacionalizáció: második vizsgálat}

A 2010-as Eurobarometer felmérés kérdőíve (jelen alfejezetben a továbbiakban: a kérdőív) egyik tematikus kérdésblokkjában ugyancsak a nemzetközi vándorlásra fókuszált. Emellett vizsgálta a válaszadó személyes kapcsolatait, kötődéseit, továbbá 
demográfiai jellegü kérdései is több olyan tényezőre irányultak, melyek felhasználhatók jelen vizsgálatban. Ezek kombinációja azt teszi lehetővé, hogy egy második vizsgálatban is teszteljük elméleti modellünk feltevéseit, így többek közöttt a lelki költségek, a tranzakciós költségek vagy a specifikus beruházások migrációs hajlandóságra gyakorolt hatásait.

Jelen vizsgálat modelljeinek eredményváltozóit a kérdőív QB8 kérdésére adott válaszokból nyertük. Ennek pontos szövegezését a 4.2. táblázat tartalmazza. Mint látható, a megfogalmazás itt jóval „puhább”, mint az első vizsgálatban használt kérdés esetén: egyrészt nem konkrét szándékra, hanem az elköltözés valószínűségére irányul, másrészt az időtáv is hosszabb, amelyre vonatkozik.

\section{2. táblázat \\ Az eredményváltozó képzéséhez felhasznált kérdés \\ a 2010-es Eurobarometer felmérésből}

QB8: Mit gondol, mennyire valószínű, hogy az elkövetkező tíz évben egy másik országba költözik?

Nagyon valószínü

Inkább valószínü

Nem nagyon valószínü

Egyáltalán nem valószínü

NT/NV

Forrás: European Commission (2012d)

A kérdés felhasználásával többféle változót is konstruálunk. Ezek egyike a migr ${ }^{2010}$ nyers migrációs potenciál dummy, amelyet a „Nagyon valószínű” és „Inkább valószínü” válaszok 1, míg a „Nem nagyon valószínü” és „Egyáltalán nem valószínü” variánsok 0 értékre történő kódolásával nyertünk. A változóban foglaltak így itt is megfelelnek a Bevezetésben definiált migráció-fogalmának. A kérdés önkéntes, országhatáron átnyúló vándorlásra vonatkozik, s bár a migráció időtartamára vagy annak konkrét céljára vonatkozó explicit információ nem jelenik meg benne, a költözés szó itt is tartósabb, letelepedéssel járó mozzanatra utal. Ugyanakkor az itt definiált migrációs potenciál jóval kevésbé konkrét, mint az első vizsgálatban meghatározott, ezért a potenciális migránsok aránya is nagyobb: a válaszadók 11,57 százaléka tartotta valószínűnek azt, hogy a következő tíz évben egy másik országba fog költözni. A ráta országonkénti változatosságát a 4.3. melléklet szemlélteti.

Emellett az első vizsgálathoz hasonlóan itt is definiálunk egy tmigr ${ }^{2010}$ tisztított migráicós potenciált. E változó alá azon válaszadókat vontuk be, akik a QB8 kérdésre a 
„Nagyon valószínü” választ adták, ezt követően pedig a QB9 kérdésre meg tudtak jelölni valamilyen célterületet, s nem a „NT/NV” választ adták. Az így meghatározott tisztított migrációs potenciállal rendelkezők aránya európai szinten mindössze 2,94 százalék, a mutató országonkénti értékeit pedig a 4.4. melléklet szemlélteti.

A kérdőív adta megfogalmazás a fentieken túl lehetővé teszi, hogy egy harmadik függő változót is használjunk, amely az eredeti válaszok mindegyikét tartalmazza. Az így képzett $m m i g r^{2010}$ változó a különböző válaszlehetőségek alapján a következő diszkrét, ám sorrendiségükben értelmezhető értékeket tartalmazza: „Nagyon valószínü” - 3; „Inkább valószínü” - 2; „Nem nagyon valószínü” - 1; „Egyáltalán nem valószínü” - 0. Az elvándorolni szándékozók e változó szerinti bontásban szemléltetett országonkénti arányát a 4.5. melléklet mutatja. Míg az előbbi függő változókat a logit, ezt a rendezett logit modell becslésekor tudjuk felhasználni.

Jelen vizsgálat egyik fókuszában a lelki költségeknek a migrációs hajlandóságra gyakorolt hatása áll. Ennek empirikus vizsgálatához a kérdőív QB13-as kérdését használjuk, amely annak felderítésére irányul, hogy a válaszadó mennyire kötődik városához/falujához, régiójához, országához, illetve az Európai Unióhoz. Ez a fajta kötődés megfeleltethető a 2.3.5. alfejezetben tárgyalt, hüségként manifesztálódó kötődéshez, amely az altruista kapcsolatok révén jelentkező lelki költségek révén fejti ki hatását. A városhoz, illetve országhoz való kötődés (a felsoroltak közül vizsgálatunkban e kettőt használjuk fel) a leírtak alapján egyfajta altruista törődést is megtestesít azok lakóival szemben, így várakozásunk szerint csökkenti a kivándorlás valószínüségét. Ezt modellünkben a Hűség_város és Hűség_ország változók bevezetésével kívánjuk tesztelni, amelyet a QB13 kérdésre adott válaszok alapján konstruáltunk. Ezeket az említett változóknál a következő kódolás szerint használjuk fel: „nagyon kötődik” - 4; „eléggé kötődik” - 3; „nem nagyon kötődik” - 2; „egyáltalán nem kötődik” - 1. A változókat a 2.3.5. alfejezetben leírtak alapján negatív előjellel várjuk a becslésbe, ami a H4 hipotézisünkhöz nyújt visszacsatolást.

Ahogyan azt az előző alfejezetben már jeleztük, a család szintén az altruista kapcsolatok bázisának tekinthető. Emellett a 2.3.4. alfejezetben leírtak alapján a családalapítás és -bővítés specifikus beruházások meghozatalát is igényli, ami hipotézisünk szerint ugyancsak csökkenti a kivándorlási hajlandóságot. Ennek empirikus teszteléséhez a Partnerrel él, Egyedülálló, Elvált, Özvegy és Házas dummykat használjuk, amelyeket a kérdőív D7 kérdésére adott válaszok alapján kaptunk. Az Elvált változó itt az adatbázis kódolása szerint a házastársuktól különélő személyeket is magába 
foglalta. Az egyéb spontán válaszokat adók esetén a dummyk értékeit hiányzó értékkel helyettesítettük. A saját háztartásban élő 15 év alatti gyermekek számát itt is a Gyermek változó jelöli, amelyet az első vizsgálathoz hasonlóan a D40b és D40c kérdésekre adott válaszok segítségével állítottunk elő. E változókkal elsősorban a H3 hipotézisünket teszteljük, de az eredmény adalékokkal szolgál a H4-re nézve is.

A potenciális altruista kötődések egyik megnyilvánulási formáját képezi le a Kisebbségi dummy változó, amelyet a kérdőív QB14 kérdése alapján képeztünk. Ez arra irányult, hogy a válaszadó országának „,egyik vallási, kulturális vagy etnikai származású kisebbségi csoportjához" tartozónak érzi-e magát. Ez azért képezheti vizsgálat tárgyát, mert Simon (1993) szerint a kisebbségi csoportokra fokozottan jellemző, hogy a csoport többi tagja iránti altruizmusra nevelik a docilis egyéneket. Így a kisebbségi lét ezen keresztül a kivándorlás - a H4 hipotézis szerinti - ellenösztönzője lehet.

Az első vizsgálathoz hasonlóan itt is egy specifikus beruházásként tekintünk a saját tulajdonban lévő ingatlanra, amelyhez az ott leírtakkal egyező módon a D46 kérdés nyújt információt. Így az Ingatlan változó e modellünkben is szerepel, amelyet H3 hipotézis alapján negatív előjellel várunk a becslésben.

A H2 hipotézis szerinti tranzakciós költségek proxyzására jelen vizsgálatban is a nyelvtudást, a migrációs hálózat meglétét és az infokommunikációs technológiához való hozzáférést használjuk. Elöbbire vonatkozóan a 2010-es felmérés közvetlen kérdéssel szolgál: a QB6 kérdés többek között azt is felmérte, hogy a válaszadó az anyanyelvén kívül beszél-e folyékonyan még legalább egy nyelvet. Az erre adott válaszokat a Nyelv dummyval építjük be modellünkbe (ez a változó az előző vizsgálathoz hasonlóan a H3 hipotézishez is nyújt visszacsatolást). A migrációs hálózat létének leképezéséhez ugyancsak a QB6 alkérdéseit használjuk. Ezek arra irányultak, hogy a válaszadónak vannak-e közeli rokonai, illetve barátai, akik külföldön élnek; ő maga dolgozott-e már külföldön három hónapnál tovább; járt-e iskolába vagy tanult-e már külföldön legalább egy szemeszteren keresztül; egyéb okokból élt-e már külföldön legalább három hónapon át; szabadáságát/hétvégéit szokta-e rendszeresen külföldön tölteni. Az ezekre adott válaszokból rendre a Hálózat_rokon, Hálózat_barát; Hálózat_munka, Hálózat_iskola, Hálózat_élet; Hálózat_szabadság dummykat képeztük, amelyek a 2.3.2. alfejezetben leírtak alapján mind elősegíthetik a kivándorlást, hiszen azáltal, hogy lehetőséget adnak a hálózat kiépítésére, csökkenthetik a keresés és a migrációs tranzakciós költségeit. A szintén tranzakciós költségcsökkentő technológiai vívmányokhoz való hozzáférést itt is az Internet változó testesíti meg, amely ezúttal a 
D62 kérdés alapján az otthoni internethasználat gyakoriságát írja le. Kódolásunk a következők szerint alakult: „Minden nap vagy majdnem minden nap” - 6; „Hetente kétszer vagy háromszor” - 5; „Körülbelül hetente egyszer” - 4; „Havonta kétszer vagy háromszor” - 3; „Ritkábban” - 2; „Soha” - 1; „Nincs internethozzáférésem” (spontán válasz) - 0. Mint azt korábban már kifejtettük, a technológia adta további lehetőségekhez való hozzáférést az egyén lakóhelyének típusa is befolyásolhatja, amelyet az első vizsgálattal megegyező módon a D25 kérdés alapján a Falu, Kisváros és Nagyváros dummyk segítségével viszünk be a modellbe.

Mindezen túl az első vizsgálathoz hasonlóan, s az ott leírtak alapján kontrollálni fogunk több demográfiai jellemzőre. Így a Kor változóban az egyén D11 kérdésből nyert korára, az Iskola változóban a D8 kérdés alapján arra, hogy hány évesen fejezte be a nappali képzést, a Nem változóban pedig a D10 kérdés alapján a válaszadó nemére (ahol $N e m=1$, ha férfi). A válaszadó munkaerőpiaci aktivitásának jelzésére az előző alfejezetben leírtakkal egyező módon itt is a D15a kérdés alapján képzett Önfoglalkoztató, Foglalkoztatott_fg; Foglalkoztatott_kg, Munkanélküli, Nyugdíjas, Tanuló dummykat használjuk.

Végül a modellek bizonyos specifikációiban kontrollálni fogunk a válaszadó anyagi helyzetére is. Ehhez egyrészröl a D60 kérdés nyújt segítséget, amely arra kérdez rá, hogy az egyénnek az elmúlt év során voltak-e problémái a számlafizetéssel hónap végén. A válaszok alapján az Anyagi változót generáltuk a következő kódolással: „Az esetek többségében” - 2; „Néha” - 1; „Szinte soha/ Soha - 0. Noha az egyén tényleges fizetésére és egy esetleges migrációtól remélt várható jövedelemre adatok hiányában nem tudunk kontrollálni, e változó is információval szolgál az anyagi helyzetéről. Az elméleti modellben leírtak alapján azt várjuk, hogy rosszabb anyagi körülmények esetén, így az Anyagi változó magasabb értékei mellett ceteris paribus a kivándorlási hajlandóság is magasabb lesz. Emellett a D61 kérdésben az alanyoknak egy 1-től 10-ig terjedő skálán kellett elhelyezni magukat, ahol előbbi a „társadalom legalacsonyabb szintjére”, utóbbi pedig a „társadalom legmagasabb szintjére” utal. Ebből a Relatív változót képeztük, amely a migráció új közgazdaságtana alapján lehet jó kontrollváltozó. Azt jelzi, hogy az egyén szubjektív megítélése alapján - az abszolút helyett - relatív viszonylatban hová pozicionálja, azaz mennyire érzi relatíve depriváltnak magát a társadalomban. A változót negatív előjellel várjuk a becslésbe. 
A fenti változókat - az első vizsgálathoz hasonlóan - különböző kombinációkban szerepeltetjük az egyes specifikációkban (részletesen lásd az 5.2. alfejezetben). Az eredmények robusztusságának tesztelése érdekében regresszióinkat különböző almintákon és különböző eredményváltozókkal is futtatjuk, illetve az itt definiált változókat ország dummykkal is kiegészítjük. 


\section{EREDMÉNYEK}

Jelen fejezetben empirikus vizsgálataink eredményét ismertetjük és diszkutáljuk. Mint azt korábban bemutattuk, ez két adatszetten történő két különálló vizsgálatot jelent, melynek eredményeit rendre az 5.1. és 5.2. alfejezetekben mutatunk be. Az egyes vizsgálatokon belül becsült különböző specifikációkat zárójelben lévő római (illetve ezek aleseteit arab) számokkal jelöljük, s a diszkusszió során is ezzel hivatkozunk rájuk.

\subsection{Első vizsgálat eredményei}

Az első vizsgálat fókuszában az intézmények, s azoknak a migrációs hajlandóság befolyásolásában játszott szerepe álltak. Ennek megfelelően első lépésként egy intézmények nélküli és egy intézményi proxykkal kiegészített modellt becsültünk, amelyeket rendre az (I) és (II) specifikációk elnevezésekkel illettünk. Ezeket rendre a (15) és (16) kifejezések írják le, amelyek a 4.1. alfejezetben szereplő (14) kifejezésbe behelyettesítve adják meg a becsülni kívánt empirikus modellt. A jelen, s a következő alfejezetben felírásra kerülő további specifikációk ugyancsak a (14) kifejezésbe helyettesítendők be.

$$
\begin{aligned}
& \operatorname{Pr}_{k}\left(m i g r^{2008}=1 \mid \boldsymbol{x}\right)=F\left(\beta_{0}+\boldsymbol{\beta} \boldsymbol{x}\right) \\
& =F\left(\beta_{0}+\beta_{1} \text { Hálózat_tapasztalat }_{k}+\beta_{2} \text { Internet }_{k}+\beta_{3} \text { Nyelv }_{k}\right. \\
& +\beta_{4} \text { Nyelv }_{k}+\beta_{5} \text { Ingatlan }_{k}+\beta_{6} \text { Partnerrel }_{k}+\beta_{7} \text { Egyedülálló }_{k} \\
& +\beta_{8} \text { Elvált }_{k}+\beta_{9} \text { Özvegy }_{k}+\beta_{10} \text { Gyermek }_{k}+\beta_{11} \text { Nem }_{k}+\beta_{12} \text { Kor }_{k} \\
& +\beta_{13} \text { Falu }_{k}+\beta_{14} \text { Kisváros }_{k}+\beta_{15} \text { Iskola }_{k}+\beta_{16} \text { Önfoglalkoztató }{ }_{k} \\
& +\beta_{17} \text { Foglalkoztatott_kékgalléros }{ }_{k}+\beta_{18} \text { Munkanélküli }{ }_{k} \\
& \left.+\beta_{19} \text { Nyugdíjas }_{k}+\beta_{20} \text { Tanuló }_{k}+\varepsilon_{k}\right) \\
& \operatorname{Pr}_{k}\left(m i g r^{2008}=1 \mid \boldsymbol{x}\right)=F\left(\beta_{0}+\boldsymbol{\beta} \boldsymbol{x}\right) \\
& =F\left(\beta_{0}+\beta_{1} \text { Hálózat_tapasztalat }_{k}+\beta_{2} \text { Internet }_{k}+\beta_{3} \text { Nyelv }_{k}\right. \\
& +\beta_{4} \text { Nyelv }_{k}+\beta_{5} \text { Ingatlan }_{k}+\beta_{6} \text { Partnerrel }_{k}+\beta_{7} \text { Egyedülálló }_{k} \\
& +\beta_{8} \text { Elvált }_{k}+\beta_{9} \text { Özvegy }_{k}+\beta_{10} \text { Gyermek }_{k}+\beta_{11} \text { Nem }_{k}+\beta_{12} \text { Kor }_{k} \\
& +\beta_{13} \text { Falu }_{k}+\beta_{14} \text { Kisváros }_{k}+\beta_{15} \text { Iskola }_{k}+\beta_{16} \text { Önfoglalkoztató }_{k} \\
& +\beta_{17} \text { Foglalkoztatott_kékgalléros }{ }_{k}+\beta_{18} \text { Munkanélküli }{ }_{k} \\
& +\beta_{19} \text { Nyugdíjas }_{k}+\beta_{20} \text { Tanuló }_{k}+\beta_{21} \text { Bizalom_jog }_{k} \\
& +\beta_{22} \text { Intézmény_iskola }{ }_{k}+\beta_{23} \text { Intézmény_munk } a_{k} \\
& +\beta_{24} \text { Intézmény_informális }+\varepsilon_{k} \text { ) }
\end{aligned}
$$


A (15) és (16) kifejezésekben a jelölések mindenben megfelelnek az eddig használtaknak, $\varepsilon$ pedig a modell heteroszkedaszticitás-kompatibilis hibatagja.

Az (I) specifikáció kizárólag olyan változókat tartalmaz, amelyek a standard vizsgálatokban is rendre előfordulnak. Számunkra, ugyanakkor ezek is információval szolgálnak hipotéziseink tesztelése szempontjából, hiszen e változók közül több is elméleti modellünk valamely sarokpontjának proxyjaként szolgál. A (II) specifikáció ezzel összevetve arról ad egy képet, hogy az intézményi tényezők modellbe emelése mennyiben változtatja meg annak eredményeit, illetve mennyi további információt ad hozzá.

Ezen túlmenően további kisebb változtatásokkal is teszteltük az (I) és (II) specifikációkat. Az (I.1.) és (I.2.) specifikációkban azt vizsgáltuk, hogy okoz-e érdemi különbséget az eredményekben, ha a nyelvtudásra vonatkozó két változó közül csak egyet-egyet szerepeltetünk a modellben. ${ }^{94}$ A (II.1) specifikáció pedig egy olyan regressziót tartalmaz, amelyben a jogrendszerrel szembeni bizalmat a Bizalom_általános változóra cseréltük. A becslések eredményeit az 5.1. táblázat tartalmazza.

\footnotetext{
${ }^{94}$ Ezt elsősorban elvi megfontolások, a 4.2. alfejezetben a változók definiálásakor leírt szempontok alapján vizsgáltuk. Amint ugyanis később tárgyaljuk, s az 5.4. mellékletben be is mutatjuk a nyelvtudás proxy változói esetén a VIF mutatók nem vesznek fel kritikus értéket. A Nyelv1 változó 6 körüli VIF mutatói is legfeljebb csak gyenge multikollinearitásra utalhatnak, amelyek - mint látni fogjuk - nem befolyásolják érdemben a modellek eredményeinek robusztusságát.
} 
A migrációs hajlandóságot meghatározó tényezők az EU állampolgárai körében (2008).

Az (I), (II), (I.1), (I.2) és (II.1) specifikációjú logit modellek marginális hatásai

\begin{tabular}{|c|c|c|c|c|c|}
\hline & (I) & (II) & $(\mathrm{I} .1)$ & (I.2) & (II.1) \\
\hline Hálózat_tapasztalat & $\begin{array}{c}0.0556 * * * \\
(0.00598)\end{array}$ & $\begin{array}{c}0.0581 * * * \\
(0.00627)\end{array}$ & $\begin{array}{c}0.0581 * * * \\
(0.00617)\end{array}$ & $\begin{array}{c}0.0577 * * * \\
(0.00610)\end{array}$ & $\begin{array}{c}0.0593 * * * \\
(0.00674)\end{array}$ \\
\hline Internet & $\begin{array}{c}0.00447 * * * \\
(0.00143)\end{array}$ & $\begin{array}{c}0.00537 * * * \\
(0.00148)\end{array}$ & $\begin{array}{c}0.00481 * * * \\
(0.00144)\end{array}$ & $\begin{array}{c}0.00469 * * * \\
(0.00145)\end{array}$ & $\begin{array}{c}0.00594 * * * \\
(0.00156)\end{array}$ \\
\hline Nyelv1 & $\begin{array}{c}0.00721 * * * \\
(0.00163)\end{array}$ & $\begin{array}{c}0.00683 * * * \\
(0.00170)\end{array}$ & $\begin{array}{c}0.00845 * * * \\
(0.00152)\end{array}$ & & $\begin{array}{c}0.00709 * * * \\
(0.00179)\end{array}$ \\
\hline Nyelv2 & $\begin{array}{c}0.00495 * * * \\
(0.00131)\end{array}$ & $\begin{array}{c}0.00486 * * * \\
(0.00135)\end{array}$ & & $\begin{array}{c}0.00615 * * * \\
(0.00131)\end{array}$ & $\begin{array}{c}0.00518 * * * \\
(0.00144)\end{array}$ \\
\hline Ingatlan & $\begin{array}{l}-0.00238 * \\
(0.00143)\end{array}$ & $\begin{array}{l}-0.00161 \\
(0.00145)\end{array}$ & $\begin{array}{l}-0.00233 \\
(0.00144)\end{array}$ & $\begin{array}{l}-0.00250 * \\
(0.00146)\end{array}$ & $\begin{array}{l}-0.00161 \\
(0.00153)\end{array}$ \\
\hline Partnerrel & $\begin{array}{c}0.0125 * * * \\
(0.00327)\end{array}$ & $\begin{array}{c}0.0125 * * * \\
(0.00335)\end{array}$ & $\begin{array}{c}0.0128 * * * \\
(0.00331)\end{array}$ & $\begin{array}{c}0.0128 * * * \\
(0.00334)\end{array}$ & $\begin{array}{c}0.0129 * * * \\
(0.00359)\end{array}$ \\
\hline Egyedülálló & $\begin{array}{c}0.0142 * * * \\
(0.00318)\end{array}$ & $\begin{array}{c}0.0146 * * * \\
(0.00331)\end{array}$ & $\begin{array}{c}0.0145 * * * \\
(0.00323)\end{array}$ & $\begin{array}{c}0.0142 * * * \\
(0.00321)\end{array}$ & $\begin{array}{c}0.0143 * * * \\
(0.00347)\end{array}$ \\
\hline Elvált & $\begin{array}{c}0.0195 * * * \\
(0.00439)\end{array}$ & $\begin{array}{c}0.0190 * * * \\
(0.00439)\end{array}$ & $\begin{array}{c}0.0197 * * * \\
(0.00442)\end{array}$ & $\begin{array}{c}0.0194 * * * \\
(0.00440)\end{array}$ & $\begin{array}{c}0.0198 * * * \\
(0.00466)\end{array}$ \\
\hline Özvegy & $\begin{array}{c}0.00494 \\
(0.00582)\end{array}$ & $\begin{array}{c}0.00547 \\
(0.00597)\end{array}$ & $\begin{array}{c}0.00500 \\
(0.00586)\end{array}$ & $\begin{array}{c}0.00502 \\
(0.00591)\end{array}$ & $\begin{array}{c}0.00614 \\
(0.00630)\end{array}$ \\
\hline Gyermek & $\begin{array}{c}-0.000838 \\
(0.000772)\end{array}$ & $\begin{array}{l}-0.000877 \\
(0.000803)\end{array}$ & $\begin{array}{c}-0.000896 \\
(0.000775)\end{array}$ & $\begin{array}{l}-0.000838 \\
(0.000784)\end{array}$ & $\begin{array}{c}-0.000705 \\
(0.000809)\end{array}$ \\
\hline Nem & $\begin{array}{c}0.00604 * * * \\
(0.00132)\end{array}$ & $\begin{array}{c}0.00616 * * * \\
(0.00135)\end{array}$ & $\begin{array}{c}0.00608 * * * \\
(0.00133)\end{array}$ & $\begin{array}{c}0.00598 * * * \\
(0.00133)\end{array}$ & $\begin{array}{c}0.00629 * * * \\
(0.00142)\end{array}$ \\
\hline Kor & $\begin{array}{c}-0.000806 * * * \\
(7.47 \mathrm{e}-05)\end{array}$ & $\begin{array}{c}-0.000806 * * * \\
(7.71 \mathrm{e}-05)\end{array}$ & $\begin{array}{c}-0.000816^{* * *} \\
(7.52 \mathrm{e}-05)\end{array}$ & $\begin{array}{c}-0.000822 * * * \\
(7.57 \mathrm{e}-05)\end{array}$ & $\begin{array}{c}-0.000780 * * * \\
(8.10 \mathrm{e}-05)\end{array}$ \\
\hline Falu & $\begin{array}{c}-0.00815^{* * * *} \\
(0.00144)\end{array}$ & $\begin{array}{c}-0.00788 * * * \\
(0.00148)\end{array}$ & $\begin{array}{c}-0.00830 * * * \\
(0.00145)\end{array}$ & $\begin{array}{c}-0.00837 * * * \\
(0.00145)\end{array}$ & $\begin{array}{c}-0.00867 * * * \\
(0.00155)\end{array}$ \\
\hline Kisvaros & $\begin{array}{c}-0.00353 * * * \\
(0.00131)\end{array}$ & $\begin{array}{c}-0.00334 * * \\
(0.00136)\end{array}$ & $\begin{array}{c}-0.00363 * * * \\
(0.00132)\end{array}$ & $\begin{array}{c}-0.00369 * * * \\
(0.00132)\end{array}$ & $\begin{array}{c}-0.00373 * * * \\
(0.00141)\end{array}$ \\
\hline Iskola & $\begin{array}{c}0.000472 * * * \\
(0.000116)\end{array}$ & $\begin{array}{c}0.000517 * * * \\
(0.000121)\end{array}$ & $\begin{array}{c}0.000510 * * * \\
(0.000116)\end{array}$ & $\begin{array}{c}0.000499 * * * \\
(0.000118)\end{array}$ & $\begin{array}{c}0.000473 * * * \\
(0.000126)\end{array}$ \\
\hline Önfoglalkoztató & $\begin{array}{c}0.00962 * * * \\
(0.00353)\end{array}$ & $\begin{array}{c}0.00936 * * * \\
(0.00356)\end{array}$ & $\begin{array}{c}0.00966 * * * \\
(0.00356)\end{array}$ & $\begin{array}{c}0.00965 * * * \\
(0.00357)\end{array}$ & $\begin{array}{c}0.00955^{* *} * \\
(0.00375)\end{array}$ \\
\hline Foglalkoztatott_kék-galléros & $\begin{array}{c}0.00461 * * \\
(0.00209)\end{array}$ & $\begin{array}{l}0.00350 * \\
(0.00208)\end{array}$ & $\begin{array}{c}0.00415 * * \\
(0.00207)\end{array}$ & $\begin{array}{c}0.00445 * * \\
(0.00211)\end{array}$ & $\begin{array}{c}0.00282 \\
(0.00216)\end{array}$ \\
\hline Munkanélküli & $\begin{array}{c}0.0112 * * * \\
(0.00312)\end{array}$ & $\begin{array}{c}0.0104 * * * \\
(0.00312)\end{array}$ & $\begin{array}{c}0.0109 * * * \\
(0.00310)\end{array}$ & $\begin{array}{c}0.0109 * * * \\
(0.00313)\end{array}$ & $\begin{array}{c}0.0120 * * * \\
(0.00341)\end{array}$ \\
\hline Nyugdíjas & $\begin{array}{l}-0.00149 \\
(0.00339)\end{array}$ & $\begin{array}{l}-0.00226 \\
(0.00338)\end{array}$ & $\begin{array}{l}-0.00154 \\
(0.00341)\end{array}$ & $\begin{array}{l}-0.00177 \\
(0.00342)\end{array}$ & $\begin{array}{l}-0.00146 \\
(0.00353)\end{array}$ \\
\hline Tanuló & $\begin{array}{c}0.0150 * * * \\
(0.00355)\end{array}$ & $\begin{array}{c}0.0151 * * * \\
(0.00367)\end{array}$ & $\begin{array}{c}0.0152 * * * \\
(0.00360)\end{array}$ & $\begin{array}{c}0.0151 * * * \\
(0.00358)\end{array}$ & $\begin{array}{c}0.0160 * * * \\
(0.00397)\end{array}$ \\
\hline Bizalom_jog & & $\begin{array}{c}-0.00742 * * * \\
(0.00128)\end{array}$ & & & \\
\hline Intézmény_informális & & $\begin{array}{c}-0.00505 * * * \\
(0.00136)\end{array}$ & & & $\begin{array}{c}-0.00508 * * * \\
(0.00142)\end{array}$ \\
\hline Bizalom_általános & & & & & $\begin{array}{c}-0.0127 * * * \\
(0.00187)\end{array}$ \\
\hline $\begin{array}{l}\mathrm{N} \\
\text { Pszeudo R-négyzet }\end{array}$ & $\begin{array}{c}24,183 \\
0.211\end{array}$ & $\begin{array}{c}22,993 \\
0.211\end{array}$ & $\begin{array}{c}24,183 \\
0.209\end{array}$ & $\begin{array}{c}24,183 \\
0.209\end{array}$ & $\begin{array}{c}20,618 \\
0.213\end{array}$ \\
\hline
\end{tabular}

Robusztus standard hibák zárójelben.

$* * * \mathrm{p}<0.01, * * \mathrm{p}<0.05, * \mathrm{p}<0.1$

Referenciacsoportokat meghatározó változók: Házas, Nagyváros, Foglalkoztatott_fehérgalléros

Forrás: saját számitás European Commission (2012c) alapján 
A különböző specifikációk eredményeiből többnyire egységes kép rajzolódik ki. A modellek változóinak többsége a szokásos szignifikancia szintek mellett - azon belül jelentős részük 1 százalékos szignifikancia szinten is - szignifikáns, elöjelük pedig egyezik a várakozásainkkal. A marginális hatások nagysága szinte kivétel nélkül alacsony, azonban ez több tényezőnek tudható be. Egyrészt itt eleve százalékos értékekről van szó, másrészt a kapott nagyságok az adatok adottságaival és magával a jelenség természetével magyarázhatók (értsd: a kivándorolni szándékozók aránya mind az adatszetten belül, mind az azt reprezentálni hivatott teljes populáción belül alacsony). Mindazonáltal hangsúlyozandó, hogy vizsgálatunk szempontjából ezek kevésbé relevánsak, így elsősorban a változók szignifikanciájára, együtthatóinak előjelére és bizonyos összehasonlítható esetekben ezeknek az egymáshoz viszonyított relatív nagyságukra fókuszálunk. Az eredmények diszkussziója során a közgazdaság-tudományi gyakorlatnak megfelelően mindenhol a ceteris paribus feltevéssel élünk.

A tranzakciós költségek kapcsán a becslések alátámasztják a H2 hipotézisben foglaltakat. A Hálózat_tapasztalat, Internet, Nyelv1, Nyelv2 változók mindegyike 0,01 alatti p-értékkel rendelkezik valamennyi specifikációban, s előjelük is a várakozásoknak megfelelően alakult. Ez azt példázza, hogy a külföldi tapasztalattal szerzett migrációs hálózat, az internet-hozzáférés, valamint a nyelvtudás megléte elméleti modellünk szerint a keresés és a migráció tranzakciós költségeinek csökkentése révén - mind hozzájárulnak a kivándorlási hajlandóság növekedéséhez. Külön kiemelést érdemel a Hálózat_tapasztalat változó, amelynek együtthatója lényegesen nagyobb a többinél: mindegyik becslés azt mutatja, hogy az, ha valaki korábban élt már külföldön, önmagában több mint 5,5 százalékponttal növeli a kivándorlási hajlandóság megfogalmazódásának valószínüségét. Ezen eredmény kapcsán - amely igazolja várakozásainkat, s a szakirodalmi tapasztalatokkal is összhangban van - természetesen megjegyzendő, hogy a nagymértékű hatás nem feltétlenül csak a külföldön élés által felépülő migrációs hálózatnak, s annak tranzakciós költségcsökkentő természetének tudható be, hanem egyéb, például attitüdbeli változásoknak is. Ezek részletes tárgyalása azonban kívül esik jelen disszertáció fókuszán.

A válaszadók lakhelyének típusára vonatkozó várakozásaink - amelyek közvetve a tranzakciós költségek és a specifikus beruházások proxyjaiként is szolgálnak ugyancsak beigazolódtak. A Falu és Kisváros változók minden esetben szignifikánsak, előjelük pedig negatív. Ez azt jelzi, hogy a referenciacsoportként használt nagyvárosok 
lakóihoz képest előbbiek - a településtípus nagysága szerinti csökkenő sorrendben rendre kisebb migrációs hajlandósággal bírnak.

A további, specifikus beurházások proxyjaként szolgáló változók esetén árnyaltabb kép rajzolódik ki a becslésekből. Nem kaptunk ugyanis meggyőző eredményt arról, hogy a helyspecifikus eszköznek tekintett saját ingatlan szignifikánsan csökkentené az egyén kivándorlási hajlandóságát. Az Ingatlan változó elöjele ugyan minden specifikációban a várakozások szerint alakult, azonban csak két esetben volt szignifikáns, s ott is csak 10 százalékos szignifikancia szint mellett. Mindez pedig csak gyenge kapcsolatra utal. ${ }^{95}$ A családi állapot kapcsán szintén vegyes eredményeket látunk. Dummy változókról lévén szó, a házas személyeket használtuk referenciacsoportként. Hozzájuk képest a partnerrel élők kis mértékben ugyan, de szignifikánsan nagyobb elvándorlási hajlandóságot mutattak. Ugyanez - a várakozásoknak megfelelően némiképp nagyobb marginális hatással - mondható el az egyedülállókról is. Mindez azt mutatja, hogy a partnerrel élés, s annak intézményesített formája olyan kapcsolatspecifikus beruházások meghozatalát igénylik, amelyek az egyén migrációs potenciálját is csökkentik. Az Elvált dummy esetén ugyancsak szignifikáns pozitív együtthatót láthatunk, ami összhangban van a leírtakkal, az okozhat csak némi meglepetést, hogy annak mértéke nagyobb még az egyedülállókénál is. Ez ugyan megerősítésként szolgál a házasság intézményének idioszinkratikus jellegére, de a nagyobb együtthatót talán olyan egyéb - például pszichológiai - okok magyarázhatják, amelyek kívül esnek jelen vizsgálat keretein. Inszignifikáns eredmények egyedül az Özvegy dummy esetén jelentkeztek, ez azonban nem cáfolja hipotézisünket. Pusztán arra mutat rá, hogy az özveggyé vált személyek a házasokhoz képest nem rendelkeznek szignifikánsan eltérő migrációs szándékokkal. A gyermekek számára vonatkozó változó ugyanakkor nem igazolta be várakozásainkat. Noha megfelelő előjellel szerepel az eredmények között, egyik specifikációban sem bizonyult szignifikánsnak. Ez vélhetően a kivándorlási szándék és a gyermekszám közötti kapcsolat bonyolultabb természetével magyarázható: a gyermekek léte bizonyos helyzetekben ugyanis akár növelheti a kivándorlási hajlandóságot, ha a migráció célja a róluk történő gondoskodás. Mindezek tükrében a két változó közötti kapcsolat megértése további mélyebb vizsgálatot igényelhet, amely meghaladja jelen disszertáció kereteit.

\footnotetext{
${ }^{95}$ Ugyanilyen gyenge kapcsolatot van az Ingatlan változó és az elvándorlási szándék között, ha egyéb tényezökre nem kontrollálunk. A két változóra számított Cramer-féle asszociációs együttható értéke ugyanis mindössze $C=0,1716$.
} 
A fő demográfiai jellemzőkre vonatkozó eredmények a várakozások szerint alakultak. A férfiak statisztikailag szignifikánsan nagyobb elvándorlási hajlandóságot mutattak, s az is beigazolódott, hogy a kor előre haladtával csökken az emberek migrációs kedve. Ezzel párhuzamosan az iskolában töltött évek növekedésével a migrációs potenciál is nő.

A munkaerőpiaci státuszra úgy kontrolláltunk, hogy referenciacsoportként a fehérgalléros foglalkoztatottakat használtuk. Hozzájuk képest az Önfoglalkoztatók szignifikánsan nagyobb migrációs hajlandóságot mutattak, ami egyfajta önálóbb, mobilabb attitüddel magyarázható. Utalhat ugyanakkor arra is, hogy egy foglalkoztatott a munkába álláshoz kapcsolódóan több olyan specifikus beruházást eszközöl, amelyek helyhez kötik, s ezek teszik az önfoglalkoztatókhoz képest immobilabbá őket. A kék galléros foglalkoztatottak a fehér gallérosokhoz képest kissé magasabb migrációs potenciállal bírnak, ám az erre vonatkozó eredmények nem robusztusok: a Foglalkoztatott_kg változó három regresszióban 5, egyben pedig 10 százalékos szignifikanciaszinten szignifikáns, míg egyben 0,17 feletti p-értékkel rendelkezik. Mindez - az együttható nagyságát is figyelembe véve - inkább arra utal, hogy nem feltétlenül van érdemi különbség a kék- és fehérgalléros foglalkoztatottak migrációs hajlandóságában. A Tanulók és a Munkanélküliek a referenciacsoporthoz képest egyaránt nagyobb elvándorlási hajlandósággal rendelkeznek, ami megfelel a várakozásoknak. Mindkét csoport esetén igaz ugyanis, hogy ők nem rendelkeznek olyan idioszinkratikus kapcsolatokkal a munkaerőpiacon, amelyek helyhez kötnék őket. A Nyugdíjasok esetén ugyanakkor az eredmények nem bizonyultak szignfikánsnak (noha a nyugdíjasokat általában kisebb mobilitási hajlandóságot mutatnak, ez inkább életkori sajátosságoknak tudható be, amire itt a Kor változó segítségével már kontrolláltunk).

Az eddig tárgyaltakat az (I.1) és (I.2) specifikációkban eszközölt módosítások sem változtatták meg. Utóbbi modellek pszeudo R-négyezete mindkét esetben természetszerüleg - alacsonyabb lett némileg, az összkép azonban nem módosult: a korábban szignifikáns változók továbbra is azok maradtak, előjeleik nem változtak, mindössze a p-értékeknél voltak minimális eltérések.

A (II) és (II.1) specifikációk eredményei alátámasztják az intézmények szerepével kapcsolatban megfogalmazott H1 hipotézisünket. Akik bíznak az országuk jogrendszerében, illetve igazságszolgáltatásában, vagy általánosan az intézményrendszerben, azok szignifikánsan kisebb hajlandóságot mutattak az elvándorlásra. Ugyanez igaz azokra is, akik szerint a kulturális különbségek nehézséget 
okozhatnak egy másik EU-tagállamba történő költözés esetén. Mindez arra utal, hogy mind a formális, mind az informális intézmények érdemben befolyásolhatják a migrációs kedvet Európában.

Az intézményi jellegű proxyk modellbe emelésének indokoltságát likelihood ratio teszttel is ellenőriztük. Ez alapján mind a (II), mind a (II.1) specifikáció esetében 0,01 alatti valószínüség mellett vethettük el az (I) specifikációhoz képest beemelt változók együttes szignifikanciájának hiányára vonatkozó nullhipotézist. A likelihood ratio tesztek eredményeit az 5.1. melléklet tartalmazza. ${ }^{96}$

Az intézményi tényezők beemelése ugyanakkor csak minimálisan javított a modellek magyarázóerején. Ez azonban nem megy szembe hipotézisünkkel. Egyrészt, mint arra már utaltunk, a logit modellek rendre alacsony pszeudo R-négyzet mutatókkal bírnak, így egy-egy újabb változó beemelése csak kivételes esetben tudja nagyságrendekkel megemelni annak az értékét. Különösen nehéz lenne ez olyan esetben, ahol a modell eredményváltozója a kivándorlási szándék, melynél a válaszadóknak csak töredéke bír pozitív értékkel. Ráadásul, mintánk az Európai Unió tagországaiból való, amelyen belül az intézményi különbségek egyébként is kisebbek. Így mindez arra utal, hogy az itt proxyzott intézményi tényezők nem a legfontosabb meghatározói ugyan a migrációnak, de mindenképp befolyással bírnak a kivándorlási szándékokra.

A modellek mintán belüli predikciós képessége vegyes képet mutat. A helyesen prediktált értékek aránya az (I), (II) és (II.1) specifikációk esetén rendre 95,77 százalék, 95,73 százalék és 95,79 százalék voltak. Bár ezen értékek a maradni szándékozók arányaival összevetve nem feltétlenül meggyőzők, a likelihood ratio khí négyzet próbák (G teszt) eredményei alapján minden esetben 1 százalék alatti szignifikanciaszint mellett vethetjük el azt a nullhipotézist, hogy egy konstans modell jobb becslést adna (a G tesztek eredményeit az 5.2. melléklet tartalmazza). Mindez azonban szintén a 4.1. alfejezetben leírtak tükrében értelmezendő, mely szerint a logisztikus regressziókkal becsült migrációs modellek elsősorban a szelekciós tényezők beazonosítására alkalmasak, előrejelző képességük azonban csekély.

A Hosmer-Lemeshow tesztek eredményei valamennyi specifikáció esetén jó illeszkedésre utalnak. Ezek eredményeit az 5.3. mellékletben foglaljuk össze.

\footnotetext{
96 Megjegyzendő ugyanakkor, hogy a likelihood ratio tesztek eredményeinek validitása gyenge, ugyanis több, a teszt elvégzéséhez szükséges feltétel sérül, hiszen a modelleket robusztus standard hibákkal futtattuk, s azok mintaelemszámai is eltérnek. Ennek tükrében a tesztek eredményeit közöljük ugyan, de azok fenntartásokkal kezelendők.
} 
A multikollinearitás tesztelésére valamennyi specifikáció esetében a VIF mutatókat használtuk, amelyekröl az 5.4. mellékletben adunk áttekintést. A 10-es érték feletti VIF-et kizárólag a Kor és Iskola változók esetében tapasztaltunk, igaz, ez valamennyi specifikációban megfigyelhető volt. Ez azonban a két változó természetéből, valamint az adatkezelés módjából fakad: az, hogy a válaszadáskor még nappali képzésben tanulók esetén az Iskola értéke megegyezik az egyén életkorával, sokaknál direkt kapcsolatot hoz létre a két változó között. Mivel azonban a szóban forgó változók rendre megfelelő elöjellel és 0,01 alatti p-értékekkel szerepelnek minden becslésben (tehát szignifikanciájuk nem érzékeny a specifikáció változtatására), s elméleti modellünk alapján is indokolt az együttes szerepeltetésük, ezért a VIF mutató magas értékét nem tekintjük problémának.

A modellek illeszkedésére vonatkozó információk alapján - noha a különbségek csekélyek voltak - a (II.1) specifikáció bizonyult a „legjobbnak”. Ez rendelkezett ugyanis a legnagyobb pszeudo R-négyzettel, a legjobb predikciós képességgel, s a link tesztek melynek eredményeit az 5.5. melléklet tartalmazza - is ezt erősítették meg. Ennek megfelelően az alábbiakban e specifikációval dolgozunk tovább.

A modell eredményeinek robusztusságát a következőkben úgy vizsgáljuk, hogy a (II.1) specifikációt először a „régi” (2004 előtt csatlakozott) majd az „új” (2004-ben és 2007-ben csatlakozott) tagállamok almintáin becsüljük. Emellett a specifikációban szereplő magyarázó változókat a tisztított migrációs potenciál becslésekor is felhasználjuk. Ezek eredményeit az 5.2. táblázat tartalmazza. 


\section{2. táblázat}

A migrációs hajlandóságot meghatározó tényezők az EU állampolgárai körében (2008). Az (II.1) specifikációjú logit modellek marginális hatásai a régi és az új tagállamok almintáján, illetve a tisztított migrációs potenciál becslésében

(II.1) Régi tagállamok (II.1) Új tagállamok (II.1) Tisztított migr. potenciál

\begin{tabular}{|c|c|c|c|}
\hline Hálózat_tapasztalat & $\begin{array}{c}0.0501 * * * \\
(0.00717)\end{array}$ & $\begin{array}{c}0.0731 * * * \\
(0.0153)\end{array}$ & $\begin{array}{l}0.0146 * * * \\
(0.00292)\end{array}$ \\
\hline Internet & $\begin{array}{c}0.00925 * * * \\
(0.00215)\end{array}$ & $\begin{array}{c}0.00204 \\
(0.00187)\end{array}$ & $\begin{array}{l}0.00235 * * \\
(0.000922)\end{array}$ \\
\hline Nyelv1 & $\begin{array}{c}0.00406 \\
(0.00282)\end{array}$ & $\begin{array}{c}0.00816 * * * \\
(0.00203)\end{array}$ & $\begin{array}{c}0.00383 * * * \\
(0.00103)\end{array}$ \\
\hline Nyelv2 & $\begin{array}{c}0.00761 * * * \\
(0.00201)\end{array}$ & $\begin{array}{c}0.00200 \\
(0.00172)\end{array}$ & $\begin{array}{c}0.00425 * * * \\
(0.000950)\end{array}$ \\
\hline Ingatlan & $\begin{array}{l}-0.00424 * \\
(0.00221)\end{array}$ & $\begin{array}{l}0.000850 \\
(0.00182)\end{array}$ & $\begin{array}{c}0.000515 \\
(0.000791)\end{array}$ \\
\hline Partnerrel & $\begin{array}{l}0.00927 * * \\
(0.00442)\end{array}$ & $\begin{array}{c}0.0133 * * * \\
(0.00496)\end{array}$ & $\begin{array}{c}0.00728 * * * \\
(0.00240)\end{array}$ \\
\hline Egyedülálló & $\begin{array}{c}0.0129 * * * \\
(0.00454)\end{array}$ & $\begin{array}{c}0.0144 * * * \\
(0.00496)\end{array}$ & $\begin{array}{l}0.00524 * * \\
(0.00205)\end{array}$ \\
\hline Elvált & $\begin{array}{c}0.0226 * * * \\
(0.00626)\end{array}$ & $\begin{array}{l}0.0124 * * \\
(0.00573)\end{array}$ & $\begin{array}{c}0.00796 * * * \\
(0.00282)\end{array}$ \\
\hline Özvegy & $\begin{array}{c}0.00396 \\
(0.00819)\end{array}$ & $\begin{array}{c}0.0100 \\
(0.00934)\end{array}$ & $\begin{array}{l}0.000610 \\
(0.00372)\end{array}$ \\
\hline Gyermek & $\begin{array}{c}-0.00316^{* * *} \\
(0.00120)\end{array}$ & $\begin{array}{c}0.00136 \\
(0.000848)\end{array}$ & $\begin{array}{c}0.000253 \\
(0.000438)\end{array}$ \\
\hline Nem & $\begin{array}{c}0.00741 * * * \\
(0.00194)\end{array}$ & $\begin{array}{l}0.00298 * \\
(0.00170)\end{array}$ & $\begin{array}{l}0.00170 * * \\
(0.000785)\end{array}$ \\
\hline Kor & $\begin{array}{c}-0.000735 * * * \\
(0.000111)\end{array}$ & $\begin{array}{c}-0.000740 * * * \\
(0.000110)\end{array}$ & $\begin{array}{c}-0.000316^{* * * *} \\
(5.41 \mathrm{e}-05)\end{array}$ \\
\hline Falu & $\begin{array}{c}-0.00840 * * * \\
(0.00218)\end{array}$ & $\begin{array}{c}-0.00897 * * * \\
(0.00200)\end{array}$ & $\begin{array}{c}-0.00401 * * * \\
(0.000902)\end{array}$ \\
\hline Kisvaros & $\begin{array}{l}-0.00224 \\
(0.00199)\end{array}$ & $\begin{array}{c}-0.00565 * * * \\
(0.00173)\end{array}$ & $\begin{array}{c}-0.00160 * * \\
(0.000789)\end{array}$ \\
\hline Iskola & $\begin{array}{c}0.000550 * * * \\
(0.000142)\end{array}$ & $\begin{array}{c}1.19 \mathrm{e}-05 \\
(0.000247)\end{array}$ & $\begin{array}{c}0.000166^{* *} \\
(7.73 \mathrm{e}-05)\end{array}$ \\
\hline Önfoglalkoztató & $\begin{array}{c}0.00956^{* * *} \\
(0.00465)\end{array}$ & $\begin{array}{c}0.00857 \\
(0.00564)\end{array}$ & $\begin{array}{c}0.00565^{* *} \\
(0.00238)\end{array}$ \\
\hline Foglalkoztatott_kékgalléros & $\begin{array}{l}-0.00233 \\
(0.00253)\end{array}$ & $\begin{array}{r}0.00948 * * \\
(0.00371)\end{array}$ & $\begin{array}{l}4.86 \mathrm{e}-05 \\
(0.00117)\end{array}$ \\
\hline Munkanélküli & $\begin{array}{c}0.00438 \\
(0.00379)\end{array}$ & $\begin{array}{c}0.0191 * * * \\
(0.00609)\end{array}$ & $\begin{array}{c}0.00422 * * \\
(0.00189)\end{array}$ \\
\hline Nyugdíjas & $\begin{array}{l}-0.00337 \\
(0.00416)\end{array}$ & $\begin{array}{l}-0.00139 \\
(0.00534)\end{array}$ & $\begin{array}{l}-0.000492 \\
(0.00227)\end{array}$ \\
\hline Tanuló & $\begin{array}{c}0.0161 * * * \\
(0.00532)\end{array}$ & $\begin{array}{l}0.0117 * * \\
(0.00505)\end{array}$ & $\begin{array}{c}0.00554 * * * \\
(0.00208)\end{array}$ \\
\hline Bizalom_általános & $\begin{array}{c}-0.0121 * * * \\
(0.00243)\end{array}$ & $\begin{array}{c}-0.0113 * * * \\
(0.00294)\end{array}$ & $\begin{array}{c}-0.00443 * * * \\
(0.00104)\end{array}$ \\
\hline Intézmény_informális & $\begin{array}{c}-0.00760 * * * \\
(0.00192)\end{array}$ & $\begin{array}{l}-0.00124 \\
(0.00183)\end{array}$ & $\begin{array}{c}-0.000778 \\
(0.000865)\end{array}$ \\
\hline $\mathrm{N}$ & 12,356 & 8,262 & 21,519 \\
\hline Pszeudo R-négyzet & 0.196 & 0.265 & 0.179 \\
\hline
\end{tabular}

Robusztus standard hibák zárójelben.

$* * * \mathrm{p}<0.01, * * \mathrm{p}<0.05, * \mathrm{p}<0.1$

Referenciacsoportokat meghatározó változók: Házas, Nagyváros, Foglalkoztatott_fehérgalléros

Forrás: saját számítás European Commission (2012c) alapján 
Az így kapott eredmények többnyire azonos irányba mutatnak a korábbiakkal. Előjel-változás egyetlen esetben sem tapasztalható, s a különböző becslésekben csak néhány változó veszített érdemben a szignifikanciájából. Ezek közül az Internet változó emelhető ki, amely az eredmények szerint az új tagállamokban nem gyakorol érdemi hatást a kivándorlási kedv alakulására. A nyelvtudás kapcsán azt tapasztaltuk, hogy az almintákra futtatott regressziók esetén a Nyelv1 és Nyelv2 változók együttes szerepeltetése rendre kioltotta valamelyiknek a szignifikanciáját. ${ }^{97}$ Az Ingatlan változó, amely a korábbi modellek többségében inszignifikáns volt, itt is csak a régi tagállamok almintáján, s ott is csak 90 százalékos konfidenciaintervallum mellett bizonyult szignifikánsnak. A családi állapotra vonatkozó dummyk esetén - néhol ugyan kissé magasabb p-értékkel - de a korábban látott eredmények reprodukálódtak. Kiemelendő ugyanakkor, hogy a Gyermekszámra vonatkozó változó, amely korábban nem bizonyult szignifikánsnak, a régi tagállamok mintáján a várakozásoknak megfelelő előjellel, 1 százalékos szignifikanciaszint mellett is szignifikáns lett. A demográfiai jellegü kontrollváltozók esetén többnyire szintén reprodukálódtak a korábbi eredmények, csak néhány változó veszítette el bizonyos esetekben a szignifikanciáját. Az intézményekkel szembeni általános bizalmat mérő mutatónk hatására vonatkozó eredmény ugyanakkor robusztusnak bizonyult. A Bizalom_általános változó minden esetben 0,01 alatti pértékkel és megfelelő előjellel szerepelt a becslésben, ami alátámasztani látszik a $\mathrm{H} 1$ hipotézisben foglaltakat. Ugyanez azonban nem mondható el maradéktalanul az informális intézményekről: az Intézmény_informális változó az új tagállamok almintáján és a tisztított migrációs potenciálra gyakorolt hatásának vizsgálatakor elveszítette szignifikanciáját. A G tesztek - melyek eredményeit az 5.2. melléklet tartalmazza - e három becslés esetén is megerősítik, hogy az általunk használt empirikus modellek jobbak egy egyszerü konstanst tartalmazó modellnél.

$\mathrm{Az}$ eddig tesztelt modellek magyarázó erejét a továbbiakban újabb változók bevonásával kívánjuk javítani. Mivel az 5.2. táblázatban közölt eredményekből az látszik, hogy a migráció hajtóerői nem feltétlenül azonosak valamennyi tagállamban, ezért a (II.1) specifikációt ország dummykkal egészítjük ki, hogy bizonyos országspecifikus tényezőkre is kontrolláljunk. Ezek egyaránt lehetnek makrogazdasági,

\footnotetext{
${ }^{97}$ A Nyelv1 változó VIF mutatójának 6 körüli értéke itt is legfeljebb csak gyenge multikollinearitásra utal. Minazonáltal a probléma ellenőrzésére kétszer két további kísérleti regressziót futtattunk úgy, hogy mindkét alminta esetén külön-külön szerepeltettük a két nyelvtudásra vonatkozó változót. Az így kapott eredmények alapján egyértelmü kép rajzolódik ki: mind Nyelv1, mind a Nyelv2 változó szignifikáns volt 5 százalékos szignifikancia szinten.
} 
kulturális vagy akár intézményi tényezök (vö. az 1. és 2. fejezetben leírtakkal), amelyekre modellünk eddigi változói nem tudtak kontrollálni. Ezt a modellt (II.1.1) specifikációnak nevezzük. Emellett az elméleti modellben tárgyalt viselkedési motívumok proxyjaival egészítjük ki a (II.1) specifikációt. Első lépésben az altruizmus migrációs hajlandóságra gyakorolt hatását teszteljük, amelyhez a (II.1.2) specifikációban a Lelki költség változót használjuk fel. Ezt követően a (II.1.3) specifikációban a lelki költségeken túl az egyén Elégedetlenségére is kontrollálunk. Mindezek eredményeit az 5.3. táblázat foglalja össze.

\section{3. táblázat}

\section{A migrációs hajlandóságot meghatározó tényezők az EU állampolgárai körében (2008). Az (II.1.1), (II.1.2) és (II.1.3) specifikációjú logit modellek marginális hatásai}

(II.1.1)

Hálózat_tapasztalat
Internet
Nyelv1
Nyelv2
Ingatlan
Parnerrel
Egyedülálló
Elvált
Özvegy
Gyermek
Nem
Kor
Falu
Kisváros
Iskola
Önfoglalkoztató
Foglalkoztatott_kékgalléros
Munkanélküli
Nyugdías
Tanuló
Bizalom_általános
Intézmény_informális
Lelki költség
Elégedetlenség

\begin{tabular}{|c|c|c|c|c|c|}
\hline $0.0514 * * *$ & $(0.00621)$ & $0.0566 * * *$ & $(0.00650)$ & $0.0571 * * *$ & $(0.00655)$ \\
\hline $0.00417 * * *$ & $(0.00145)$ & $0.00596 * * *$ & $(0.00154)$ & $0.00694 * * *$ & $(0.00155)$ \\
\hline $0.00651 * * *$ & $(0.00159)$ & $0.00725 * * *$ & $(0.00174)$ & $0.00739 * * *$ & $(0.00170)$ \\
\hline $0.00518 * * *$ & $(0.00130)$ & $0.00450 * * *$ & $(0.00140)$ & $0.00438 * * *$ & $(0.00139)$ \\
\hline-0.000892 & $(0.00138)$ & -0.00140 & $(0.00150)$ & -0.00136 & $(0.00148)$ \\
\hline $0.00819 * * *$ & $(0.00289)$ & $0.0126 * * *$ & $(0.00351)$ & $0.0124 * * *$ & $(0.00347)$ \\
\hline $0.0115 * * *$ & $(0.00301)$ & $0.0140 * * *$ & $(0.00340)$ & $0.0129 * * *$ & $(0.00329)$ \\
\hline $0.0148 * * *$ & $(0.00391)$ & $0.0193 * * *$ & $(0.00455)$ & $0.0176 * * *$ & $(0.00439)$ \\
\hline 0.00426 & $(0.00525)$ & 0.00573 & $(0.00612)$ & 0.00496 & $(0.00587)$ \\
\hline$-0.00152 * *$ & $(0.000751)$ & -0.000716 & $(0.000792)$ & -0.000684 & $(0.000776)$ \\
\hline $0.00533 * * *$ & $(0.00127)$ & $0.00584 * * *$ & $(0.00139)$ & $0.00574 * * *$ & $(0.00137)$ \\
\hline$-0.000705 * * *$ & $(7.34 \mathrm{e}-05)$ & $-0.000776 * * *$ & $(7.98 \mathrm{e}-05)$ & $-0.000777 * * *$ & $(7.86 \mathrm{e}-05)$ \\
\hline$-0.00768 * * *$ & $(0.00142)$ & $-0.00851 * * *$ & $(0.00152)$ & $-0.00808 * * *$ & $(0.00150)$ \\
\hline$-0.00294 * *$ & $(0.00133)$ & $-0.00366 * * *$ & $(0.00139)$ & $-0.00342 * *$ & $(0.00138)$ \\
\hline $0.000372 * * *$ & $(0.000116)$ & $0.000491 * * *$ & $(0.000122)$ & $0.000507 * * *$ & $(0.000121)$ \\
\hline $0.0119 * * *$ & $(0.00381)$ & $0.00898 * *$ & $(0.00366)$ & $0.00894 * *$ & $(0.00362)$ \\
\hline 0.00228 & $(0.00194)$ & 0.00246 & $(0.00210)$ & 0.00208 & $(0.00205)$ \\
\hline $0.0115 * * *$ & $(0.00321)$ & $0.0113 * * *$ & $(0.00330)$ & $0.00940 * * *$ & $(0.00313)$ \\
\hline-0.00243 & $(0.00302)$ & -0.00157 & $(0.00346)$ & -0.00145 & $(0.00341)$ \\
\hline $0.0157 * * *$ & $(0.00379)$ & $0.0157 * * *$ & $(0.00392)$ & $0.0168 * * *$ & $(0.00405)$ \\
\hline$-0.0118 * * *$ & $(0.00190)$ & $-0.0123 * * *$ & $(0.00184)$ & $-0.0102 * * *$ & $(0.00184)$ \\
\hline$-0.00519 * * *$ & $(0.00126)$ & $-0.00450 * * *$ & $(0.00142)$ & $-0.00454 * * *$ & $(0.00140)$ \\
\hline & & $-0.00605 * * *$ & $(0.00131)$ & $-0.00572 * * *$ & $(0.00129)$ \\
\hline & & & & $0.00374 * * *$ & $(0.000953)$ \\
\hline \multicolumn{2}{|c|}{20,618} & \multicolumn{2}{|c|}{20,618} & \multicolumn{2}{|c|}{20,556} \\
\hline \multicolumn{2}{|c|}{0.236} & \multicolumn{2}{|c|}{0.216} & \multicolumn{2}{|c|}{0.218} \\
\hline
\end{tabular}

$\mathrm{N}$

0.236

Robusztus standard hibák zárójelben.

$* * * \mathrm{p}<0.01, * * \mathrm{p}<0.05, * \mathrm{p}<0.1$

Referenciacsoportokat meghatározó változók: Házas, Nagyváros, Foglalkoztatott_fehérgalléros.

A (II.1.1) specifikáció ország dummykat is tartalmazott. A regresszió teljes outputja, mely az ország dummykhoz tartozó marginális hatásokat is tartalmazza, az 5.6. mellékletben található.

Forrás: saját számítás European Commission (2012c) alapján 
Az országdummykat tartalmazó modell a korábbi becslésekhez hasonló eredményt produkált. A legfőbb különbséget a (II.1) specifikáció alapmodelljéhez képest az jelenti, hogy a Gyermek változó szignifikánssá vált: negatív előjellel 0,043-es p-értékkel szerepel a modellben. Ez egybecseng azon várakozásainkkal, mely szerint - az idioszinkrázia miatt - a gyermekszám növekedésével ceteris paribus a kivándorlási kedv is csökken. Mivel az ország dummyk jelentős része is szignifikánsnak bizonyult, ezért joggal feltételezhetjük, hogy az egyedi jellemzőkön túl bizonyos országspecifikus hatások is érdemben befolyásolják az egyén migrációs hajlandóságát. Továbbá az emelhető ki, hogy az ország dummykat tartalmazó modell pszeudo R-négyzet mutatója 0,0238-del magasabb a (II.1) specifikációénál (a helyes predikciók aránya ugyanakkor csak 0,01 százalékponttal nagyobb). A likelihood ratio teszt alapján - amelynek eredményét az 5.1. melléklet tartalmazza - 1 százalékos szignifikancia szint mellett is elvethetjük azt a nullhipotézist, mely szerint az ország dummyk beemelése indokolatlan lett volna.

$\mathrm{Az}$ altruizmust magába foglaló (II.1.2) specifikációjú empirikus modell ugyancsak előre lepésnek tekinthető a (II.1) specifikációhoz képest. Ugyan itt a Gyermekszámra vonatkozó változó nem vált szignifikánssá, de a Lelki költségek proxyja a várakozásoknak megfelelően negatív előjellel, 0,01 alatti p-értékkel szerepel a becslésben. Ez megerősíti a H4 hipotézisben foglaltakat, mely szerint az altruizmusból fakadó lelki költségek ellenösztönzői lehetnek a kivándorlásnak. A Lelki költségekkel kiegészített modell pszeudo R-négyzete és predikciós képessége is minimálisan emelkedett az alap specifikációhoz képest (rendre 0,0031-del, illetve 0,03 százalékponttal). A változó beemelésének indokoltságát a likelihood ratio teszt is alátámasztja (lásd 5.1. melléklet).

A (II.1.3) specifikáció eredményei ugyancsak megerősítik a várakozásokat. Az Elégedetlenség megfelelő előjellel, erősen szignifikánsan növeli az elvándorlási hajlandóságot, miközben a többi változó eredményei tekintetében nem okoz változást. A modell pszeudo R-négyzete és predikciós képessége tekintetében csak marginális pozitív irányú változás figyelhető meg. A likelihood ratio teszt alapján - amelynek eredményét az 5.1. melléklet tartalmazza - indokoltnak tekinthetjük a Lelki költség és az Elégedetlenség változók együttes bevonását a modellbe.

Végül a $\mathrm{G}$ teszt alapján mindhárom esetben elvethető az a nullhipotézis, mely szerint egy konstans modell jobb becslést adna az elvándorlási hajlandóság alakulására a (II.1.1), (II.1.2) és (II.1.3) specifikációknál. 


\subsection{Második vizsgálat eredményei}

A második vizsgálat első lépésében szintén két föbb specifikációt fogunk becsülni, majd annak különböző variánsait vizsgáljuk. A (III) specifikáció az alapmodell, amely a migrációkutatásban szokásos változókat tartalmazza. Elméleti modellünk alapján azonban - csakúgy, mint az előző alfejezetben - már ez is ad visszajelzést számunkra a tranzakciós költségeknek és a specifikus beruházásoknak a migrációs hajlandóság alakításában való szerepére vonatkozóan. Ez a modell, melynek formális felírását - az eddig használt jelölésekkel egyező módon - a (17) kifejezés tartalmazza, többé-kevésbé megegyezik az előző alfejezetben becsült (I) specifikációval. Utóbbihoz képest a különbséget az jelenti, hogy a nyelvtudásra itt egyetlen közvetlen kérdésből származó dummyval kontrollálunk, a migrációs hálózatoknak pedig több fajtáját is lehetőségünk van szerepeltetni az empirikus modellben. Emellett az egyén - a 2.4. alfejezetben felvázoltak alapján ugyancsak fontos - anyagi helyzetére is módunkban áll kontrollálni. Mindezt a (IV) specifikációban a lelki költségek proxyjaként használt hüség-változókkal egészítjük ki. Ennek formális felírását a (18) kifejezés tartalmazza.

$$
\begin{aligned}
& P r_{k}\left(m i g r^{2010}=1 \mid \boldsymbol{x}\right)=F\left(\beta_{0}+\boldsymbol{\beta} \boldsymbol{x}\right) \\
& =F\left(\beta_{0}+\beta_{1} \text { Hálózat_rokon }_{k}+\beta_{2} \text { Hálózat_barát }_{k}\right. \\
& +\beta_{3} \text { Hálózat_munka } a_{k}+\beta_{4} \text { Hálózat_iskola }{ }_{k}+\beta_{5} \text { Hálózat_élet }{ }_{k} \\
& +\beta_{6} \text { Hálózat_szabadság }_{k}+\beta_{7} \text { Internet }_{k}+\beta_{8} \text { Nyelv }_{k} \\
& +\beta_{9} \text { Ingatlan }_{k}+\beta_{10} \text { Partnerrel }_{k}+\beta_{11} \text { Egyedülálló }_{k}+\beta_{12} \text { Elvált }_{k} \\
& +\beta_{13} \text { Özvegy }_{k}+\beta_{14} \text { Gyermek }_{k}+\beta_{15} \text { Nem }_{k}+\beta_{16} \text { Kor }_{k}+\beta_{17} \text { Falu }_{k} \\
& +\beta_{18} \text { Kisváros }_{k}+\beta_{19} \text { Iskola }_{k}+\beta_{20} \text { Önfoglalkoztató }_{k} \\
& +\beta_{21} \text { Foglalkoztatott_kékgalléros }_{k}+\beta_{22} \text { Munkanélküli } i_{k} \\
& \left.+\beta_{23} \text { Nyugdíjas }_{k}+\beta_{24} \text { Tanuló }_{k}+\beta_{25} \text { Anyagi }_{k}+\varepsilon_{k}\right)
\end{aligned}
$$




$$
\begin{aligned}
& \operatorname{Pr}_{k}\left(m i g r^{2010}=1 \mid \boldsymbol{x}\right)=F\left(\beta_{0}+\boldsymbol{\beta} \boldsymbol{x}\right) \\
& =F\left(\beta_{0}+\beta_{1} \text { Hálózat_rokon }{ }_{k}+\beta_{2} \text { Hálózat_barát }{ }_{k}\right. \\
& +\beta_{3} \text { Hálózat_munka } a_{k}+\beta_{4} \text { Hálózat_iskola }{ }_{k}+\beta_{5} \text { Hálózat_élet }{ }_{k} \\
& +\beta_{6} \text { Hálózat_szabadság } g_{k}+\beta_{7} \text { Internet }_{k}+\beta_{8} \text { Nyelv }_{k} \\
& +\beta_{9} \text { Ingatlan }_{k}+\beta_{10} \text { Partnerrel }_{k}+\beta_{11} \text { Egyedülálló }_{k}+\beta_{12} \text { Elvált }_{k} \\
& +\beta_{13} \text { Özvegy }_{k}+\beta_{14} \text { Gyermek }_{k}+\beta_{15} \text { Nem }_{k}+\beta_{16} \text { Kor }_{k}+\beta_{17} \text { Falu }_{k} \\
& +\beta_{18} \text { Kisváros }_{k}+\beta_{19} \text { Iskola }_{k}+\beta_{20} \text { Önfoglalkoztató }{ }_{k} \\
& +\beta_{21} \text { Foglalkoztatott_kékgalléros }{ }_{k}+\beta_{22} \text { Munkanélküli } i_{k} \\
& +\beta_{23} \text { Nyugdíjas }_{k}+\beta_{24} \text { Tanuló }_{k}+\beta_{25} \text { Anyagi }_{k}+\beta_{26} \text { Hüség_ország } \\
& \left.+\beta_{27} H \text { üség_város }+\varepsilon_{k}\right)
\end{aligned}
$$

A fentiek szerinti (III) és (IV) specifikációkat további kisebb változtatásokkal is teszteljük. A (III.1) specifikációban az anyagi problémák létét jelző változó helyett az egyén Relatív jólétérzetére kontrollálunk, a (III.2) specifikációban pedig a két anyagi helyzetet mérő változót együttesen szerepeltetjük a modellben. Ugyanezen változtatásokat a (IV) specifikáció esetén is rendre meglépjük a (IV.1) és (IV.2) specifikációkban. Végül a (IV.3) specifikációban egy újabb hüség proxyt, a Kisebbségi létre utaló változót emeljük be a modellbe. A becslések eredményeit az 5.4. táblázatban foglaljuk össze. 


\section{4. táblázat}

A migrációs hajlandóságot meghatározó tényezők az EU állampolgárai körében (2010).

\section{A (III), (IV), (III.1), (III.2) (IV.1), (IV.2) és (IV.3) specifikációjú logit modellek marginális hatásai}

\begin{tabular}{|c|c|c|c|c|c|c|c|c|}
\hline & \multicolumn{2}{|c|}{ (III) } & \multicolumn{2}{|c|}{ (IV) } & \multicolumn{2}{|c|}{ (III.1) } & \multicolumn{2}{|c|}{ (III.2) } \\
\hline Hálózat_rokon & $0.0184 * * *$ & $(0.00281)$ & $0.0190 * * *$ & $(0.00273)$ & $0.0203 * * *$ & $(0.00291)$ & $0.0181 * * *$ & $(0.00286)$ \\
\hline Hálózat_barát & $0.0457 * * *$ & $(0.00303)$ & $0.0425 * * *$ & $(0.00291)$ & $0.0474 * * *$ & $(0.00312)$ & $0.0462 * * *$ & $(0.00309)$ \\
\hline Hálózat_munka & $0.0359 * * *$ & $(0.00466)$ & $0.0330 * * *$ & $(0.00441)$ & $0.0364 * * *$ & $(0.00479)$ & $0.0359 * * *$ & $(0.00474)$ \\
\hline Hálózat_iskola & $0.0103^{* *}$ & $(0.00441)$ & $0.00910 * *$ & $(0.00417)$ & $0.0107 * *$ & $(0.00460)$ & $0.0110 * *$ & $(0.00455)$ \\
\hline Hálózat_élet & $0.0313 * * *$ & $(0.00529)$ & $0.0266 * * *$ & $(0.00489)$ & $0.0312 * * *$ & $(0.00544)$ & $0.0311 * * *$ & $(0.00539)$ \\
\hline Hálózat_szabadság & $0.0164 * * *$ & $(0.00316)$ & $0.0119 * * *$ & $(0.00291)$ & $0.0138^{* * *}$ & $(0.00314)$ & $0.0166^{* * *}$ & $(0.00322)$ \\
\hline Internet & $0.00383^{* * *}$ & $(0.000613)$ & $0.00321 * * *$ & $(0.000583)$ & $0.00326 * * *$ & $(0.000637)$ & $0.00382 * * *$ & $(0.000633)$ \\
\hline Nyelv & $0.0184 * * *$ & $(0.00268)$ & $0.0162 * * *$ & $(0.00256)$ & $0.0191 * * *$ & $(0.00277)$ & $0.0188 * * *$ & $(0.00273)$ \\
\hline Ingatlan & $-0.0166^{* * *}$ & $(0.00297)$ & $-0.0114 * * *$ & $(0.00273)$ & $-0.0172 * * *$ & $(0.00308)$ & $-0.0164 * * *$ & $(0.00304)$ \\
\hline Partnerrel & $0.0136^{* * *}$ & $(0.00442)$ & $0.0117 * * *$ & $(0.00415)$ & $0.0144 * * *$ & $(0.00458)$ & $0.0128 * * *$ & $(0.00443)$ \\
\hline Egyedülálló & $0.0226 * * *$ & $(0.00426)$ & $0.0196 * * *$ & $(0.00403)$ & $0.0230 * * *$ & $(0.00441)$ & $0.0219 * * *$ & $(0.00431)$ \\
\hline Elvált & $0.0190 * * *$ & $(0.00601)$ & $0.0158 * * *$ & $(0.00558)$ & $0.0240 * * *$ & $(0.00645)$ & $0.0185^{* * *}$ & $(0.00611)$ \\
\hline Özvegy & 0.00979 & $(0.00871)$ & 0.0105 & $(0.00857)$ & 0.0115 & $(0.00912)$ & 0.0101 & $(0.00885)$ \\
\hline Gyermek & $-0.00634 * * *$ & $(0.00134)$ & $-0.00663 * * *$ & $(0.00130)$ & $-0.00617 * * *$ & $(0.00138)$ & $-0.00666 * * *$ & $(0.00136)$ \\
\hline Nem & $0.0101 * * *$ & $(0.00237)$ & $0.00809 * * *$ & $(0.00226)$ & $0.00970 * * *$ & $(0.00245)$ & $0.00976 * * *$ & $(0.00242)$ \\
\hline Kor & $-0.00206^{* * *}$ & $(0.000128)$ & $-0.00188 * * *$ & $(0.000122)$ & $-0.00220 * * *$ & $(0.000133)$ & $-0.00209 * * *$ & $(0.000131)$ \\
\hline Falu & $-0.00879 * * *$ & $(0.00278)$ & $-0.0113 * * *$ & $(0.00263)$ & $-0.00926 * * *$ & $(0.00288)$ & $-0.00827 * * *$ & $(0.00285)$ \\
\hline Kisváros & $8.30 \mathrm{e}-05$ & $(0.00268)$ & -0.00242 & $(0.00253)$ & $-8.63 e-05$ & $(0.00276)$ & 0.000252 & $(0.00274)$ \\
\hline Iskola & $0.000839 * * *$ & $(0.000252)$ & $0.000701 * * *$ & $(0.000239)$ & $0.000724 * * *$ & $(0.000264)$ & $0.000832 * * *$ & $(0.000259)$ \\
\hline Önfoglalkoztató & 0.00547 & $(0.00494)$ & 0.00411 & $(0.00461)$ & $0.00891 *$ & $(0.00537)$ & 0.00628 & $(0.00510)$ \\
\hline Foglalkoztatott_kékgalléros & $0.00992 * * *$ & $(0.00383)$ & $0.00874 * *$ & $(0.00362)$ & $0.0111 * * *$ & $(0.00401)$ & $0.00981 * *$ & $(0.00391)$ \\
\hline Munkanélküli & $0.0211 * * *$ & $(0.00456)$ & $0.0172 * * *$ & $(0.00427)$ & $0.0275^{* * *}$ & $(0.00494)$ & $0.0211 * * *$ & $(0.00466)$ \\
\hline Nyugdíjas & $-0.0132 * * *$ & $(0.00494)$ & $-0.0132 * * *$ & $(0.00466)$ & $-0.0141 * * *$ & $(0.00514)$ & $-0.0136^{* * *}$ & $(0.00505)$ \\
\hline Tanuló & $0.0512 * * *$ & $(0.00768)$ & $0.0488 * * *$ & $(0.00743)$ & $0.0516^{* * *}$ & $(0.00776)$ & $0.0514 * * *$ & $(0.00783)$ \\
\hline Anyagi & $0.0179 * * *$ & $(0.00181)$ & $0.0162 * * *$ & $(0.00173)$ & & & $0.0177 * * *$ & $(0.00195)$ \\
\hline Hüség_ország & & & $-0.0202 * * *$ & $(0.00175)$ & & & & \\
\hline Hüség_település & & & $-0.0102 * * *$ & $(0.00152)$ & & & & \\
\hline Relatív & & & & & $-0.00264 * * *$ & $(0.000799)$ & -0.000769 & $(0.000819)$ \\
\hline $\mathrm{N}$ & 24,3 & & 24,2 & & 24,1 & & & \\
\hline Pszeudo R-négyzet & 0.2 & & 0.2 & & 0.2 & & 0.2 & \\
\hline
\end{tabular}

Robusztus standard hibák zárójelben.

$* * * \mathrm{p}<0.01, * * \mathrm{p}<0.05, * \mathrm{p}<0.1$

Referenciacsoportokat meghatározó változók: Házas, Nagyváros, Foglalkoztatott_fehérgalléros. 
5.4. táblázat (folyt.)

(IV.1) (IV

\begin{tabular}{|c|c|c|c|c|c|c|}
\hline & \multicolumn{2}{|c|}{ (IV.1) } & \multicolumn{2}{|c|}{ (IV.2) } & \multicolumn{2}{|c|}{ (IV.3) } \\
\hline Hálózat_rokon & $0.0208 * * *$ & $(0.00282)$ & $0.0188 * * *$ & $(0.00277)$ & $0.0182 * * *$ & $(0.00302)$ \\
\hline Hálózat_barát & $0.0444 * * *$ & (0.00299) & $0.0430 * * *$ & $(0.00297)$ & $0.0438 * * *$ & $(0.00325)$ \\
\hline Hálózat_munka & $0.0331 * * *$ & $(0.00452)$ & $0.0329 * * *$ & $(0.00449)$ & $0.0334 * * *$ & $(0.00489)$ \\
\hline Hálózat_iskola & $0.00928 * *$ & $(0.00433)$ & $0.00973 * *$ & $(0.00430)$ & 0.00534 & $(0.00443)$ \\
\hline Hálózat_élet & $0.0265 * * *$ & $(0.00503)$ & $0.0266^{* * *}$ & $(0.00498)$ & $0.0261 * * *$ & $(0.00544)$ \\
\hline Hálózat_szabadság & $0.00952 * * *$ & $(0.00290)$ & $0.0120 * * *$ & $(0.00297)$ & $0.0118 * * *$ & $(0.00322)$ \\
\hline Internet & $0.00261 * * *$ & $(0.000605)$ & $0.00313 * * *$ & $(0.000602)$ & $0.00400 * * *$ & $(0.000682)$ \\
\hline Nyelv & $0.0168 * * *$ & $(0.00264)$ & $0.0165 * * *$ & $(0.00261)$ & $0.0137 * * *$ & $(0.00282)$ \\
\hline Ingatlan & $-0.0118 * * *$ & $(0.00283)$ & $-0.0113 * * *$ & $(0.00280)$ & $-0.0118 * * *$ & $(0.00309)$ \\
\hline Partnerrel & $0.0127 * * *$ & $(0.00430)$ & $0.0111 * * *$ & $(0.00417)$ & $0.00996 * *$ & $(0.00452)$ \\
\hline Egyedülálló & $0.0200 * * *$ & $(0.00417)$ & $0.0190 * * *$ & $(0.00408)$ & $0.0196 * * *$ & $(0.00447)$ \\
\hline Elvált & $0.0206 * * *$ & $(0.00602)$ & $0.0155^{* * *}$ & $(0.00568)$ & $0.0131 * *$ & $(0.00617)$ \\
\hline Özvegy & 0.0123 & $(0.00895)$ & 0.0109 & $(0.00872)$ & 0.00331 & $(0.00892)$ \\
\hline Gyermek & $-0.00642 * * *$ & $(0.00133)$ & $-0.00692 * * *$ & $(0.00132)$ & $-0.00823 * * *$ & $(0.00149)$ \\
\hline Nem & $0.00760 * * *$ & $(0.00232)$ & $0.00775 * * *$ & $(0.00230)$ & $0.00714 * * *$ & $(0.00252)$ \\
\hline Kor & $-0.00201 * * *$ & $(0.000126)$ & $-0.00190 * * *$ & $(0.000125)$ & $-0.00193 * * *$ & $(0.000136)$ \\
\hline Falu & $-0.0116^{* * *}$ & $(0.00272)$ & $-0.0107 * * *$ & $(0.00270)$ & $-0.00886 * * *$ & $(0.00297)$ \\
\hline Kisváros & -0.00264 & $(0.00261)$ & -0.00218 & $(0.00259)$ & -0.000861 & $(0.00287)$ \\
\hline Iskola & $0.000615 * *$ & $(0.000249)$ & $0.000704 * * *$ & $(0.000245)$ & $0.000701 * * *$ & $(0.000263)$ \\
\hline Önfoglalkoztató & 0.00697 & $(0.00498)$ & 0.00480 & $(0.00475)$ & 0.00777 & $(0.00541)$ \\
\hline Foglalkoztatott_kékgalléros & $0.0101 * * *$ & $(0.00381)$ & $0.00885^{* *}$ & $(0.00370)$ & $0.0103 * *$ & $(0.00414)$ \\
\hline Munkanélküli & $0.0234 * * *$ & $(0.00465)$ & $0.0175^{* * *}$ & $(0.00437)$ & $0.0211 * * *$ & $(0.00506)$ \\
\hline Nyugdíjas & $-0.0137 * * *$ & $(0.00484)$ & $-0.0135 * * *$ & $(0.00475)$ & -0.00865 & $(0.00538)$ \\
\hline Tanuló & $0.0493 * * *$ & $(0.00752)$ & $0.0491 * * *$ & $(0.00759)$ & $0.0504 * * *$ & $(0.00833)$ \\
\hline Anyagi & & & $0.0161 * * *$ & $(0.00186)$ & $0.0159 * * *$ & $(0.00196)$ \\
\hline Hüség_ország & $-0.0213 * * *$ & $(0.00180)$ & $-0.0206 * * *$ & $(0.00178)$ & $-0.0195 * * *$ & $(0.00196)$ \\
\hline Hüség_település & $-0.0100 * * *$ & $(0.00156)$ & $-0.0100 * * *$ & $(0.00155)$ & $-0.0100 * * *$ & $(0.00170)$ \\
\hline Relatív & $-0.00207 * * *$ & $(0.000755)$ & -0.000366 & $(0.000776)$ & & \\
\hline Kisebbségi & & & & & $0.0202 * * *$ & $(0.00473)$ \\
\hline $\mathrm{N}$ & 24,0 & & 23, & & 19,4 & \\
\hline Pszeudo R-négyzet & 0.2 & & 0.2 & & 0.28 & \\
\hline
\end{tabular}

Robusztus standard hibák zárójelben.

$* * * \mathrm{p}<0.01, * * \mathrm{p}<0.05, * \mathrm{p}<0.1$

Referenciacsoportokat meghatározó változók: Házas, Nagyváros, Foglalkoztatott_fehérgalléros.

Forrás: saját számitás European Commission (2012d) alapján 
A különböző specifikációk eredményeiből egységes kép rajzolódik ki, ami ráadásul összhangban van az első vizsgálat becsléseivel is. A modellek változóinak többsége a szokásos szignifikancia szintek mellett, jelentős részük pedig azon belül még 1 százalékon is szignifikáns. Előjelük egy kivétellel egyezik a várakozásainkkal. A marginális hatások nagysága e vizsgálatban is alacsony, azonban ez itt is az előző alfejezetben kifejtett tényezőknek tudható be. Az eredmények diszkussziójakor továbbra is a ceteris paribus feltevéssel élünk.

A vizsgálat eredményei alátámasztják a tranzakciós költségek migrációs hajlandóságot befolyásoló szerepével kapcsolatos H2 hipotézisünket. A Hálózat_rokon, Hálózat_barát; Hálózat_munka, Hálózat_iskola, Hálózat_élet; Hálózat_szabadság változók egy kivétellel (Hálózat_iskola a (IV.1) specifikációban) valamennyi vizsgálatban erősen szignifikánsak. Marginális hatásaik nagysága ugyancsak arra utal, hogy a migrációs hálózatok megléte - annak valamennyi formájában érdemben csökkenteni tudja a kereséshez és a kivándorláshoz kapcsolódó tranzakciós költségek mértékét, ami ezáltal érdemben emeli a hálózattal rendelkező egyének kivándorlási kedvét. Az Internet és a Nyelv változók 0,01 alatti p-értékei (rendre minden specifikációban) ugyancsak arra utalnak, hogy a világháló rendszeres használata és az idegennyelv-tudás hozzájárulnak a migrációs potenciál emelkedéséhez. A Nyelv változó eredményei pedig, figyelembe véve, hogy a nyelvtudás megléte azt is jelzi, hogy az egyén humántőkéje kevésbé országspecifikus, még a H3 hipotézishez is megerősítésként szolgál.

A különböző településtípusokon élők kivándorlási kedvében feltételezett eltérések azonban jelen vizsgálatokban csak részben igazolódtak be. A vidék és a falvak lakói (Falu) ugyan szignifikánsan kisebb migrációs potenciállal bírnak, mint a referenciacsoportként használt Nagyvárosokban élők, ám hasonló, statisztikailag is szignifikáns különbség a Kisvárosok lakosai esetén nem mutatkozott.

A specifikus beruházásoknak az elvándorlási kedv alakításában játszott szerepével kapcsolatban az itt becsült regressziók még az első vizsgálat eredményeinél is egyértelmübb képet mutatnak. Ellentétben az előző alfejezetben tapasztaltakkal, a saját ingatlannal való rendelkezés (Ingatlan) jelen modellek mindegyike szerint érdemben és szignifikánsan csökkenti a migrációs hajlandóságot. A családi állapottal kapcsolatban hasonló a helyzet. A Partnerel élők, az Egyedülállók, s az Elváltak is mind nagyobb elvándorlási potenciállal bírtak referenciacsoportként használt Házasokhoz képest, ami 
megerősíti a házasság intézményéhez kapcsolódó specifikus beruházások marasztaló erejére vonatkozó feltevésünket. Inszignifikáns eredmény kizárólag az özvegyek esetén mutatkozott. Jelen vizsgálatokban ráadásul a Gyermekek számát jelző változó is minden specifikációban negatív előjellel és 0,01 alatti p-értékkel bírt, ami ezúttal a gyermekvállalás idioszinkratikus jellegét is alátámasztja. Mindez pedig összhangban van a H3 hipotézisünkben megfogalmazott feltevésekkel.

A munkaerőpiaci aktivitásra kontrolláló változók kapcsán az eredmények némiképp eltérnek az első vizsgálatban tapasztaltaktól. A referenciacsoportként használt fehérgalléros foglalkoztatottakhoz képest az Önfoglalkoztatók itt nem rendelkeznek statisztikailag szignifikánsan eltérő kivándorlási szándékokkal, ellenben a kékgalléros foglalkoztatottak magasabb migrációs potenciáljára vonatkozó eredmények itt szignifikánsabbak. Ugyancsak kiemelendő az első vizsgálathoz képest, hogy itt a Nyugdíjasok alacsonyabb elvándorlási hajlandóságára vonatkozó várakozásaink szignifikánsan beigazolódtak. A Munkanélküliek és a Tanulók esetében várt jelentősebb kivándorlási kedvre vonatkozó feltevések szintén igazolódtak az 1 százalékos szignifikancia szint mellett.

A demográfiai jellegủ változók esetén ugyancsak beigazolódtak a várakozásaink. A férfiak és az iskolázottabb személyek 1 százalékos szignifikanciaszint mellett is rendre magasabb, míg az idősebbek alacsonyabb elvándorlási hajlandóságot mutattak minden specifikációban.

A fentieken túl jelen vizsgálatban lehetőségünk volt kontrollálni az egyén anyagi helyzetére is, ráadásul több formában. Az Anyagi változó valamennyi specifikációban szignifikánsnak bizonyult, ami megerősíti, hogy a pénzügyi problémák megjelenése, s annak rendszerességének növekedése ceteris paribus hozzájárul a kivándorlási kedv fokozódásához. Emellett bizonyos specifikációkban az egyén szubjektív ítélete szerinti relatív anyagi helyzetre is kontrolláltunk. A Relatív változó előjelei azt mutatják, hogy minél lejjebb helyezi magát valaki a társadalmi ranglétrán, annál hajlamosabb lehet az elvándorlásra. Ugyanakkor e változó kizárólag azokban az esetekben volt szignifikáns igaz, akkor 1 százalékos szignifikanciaszint alatt - amikor a modellben az Anyagi változó nem szerepelt. Együttes szereplésük esetén utóbbi kioltotta az előbbi hatását, amelynek okait a modelldiagnosztika során tárgyaljuk.

A $(I V),(I V .1),(I V .2)$ és (IV.3) specifikációk eredményei alátámasztják azon H4 hipotézisben is megfogalmazott várakozásainkat, mely szerint az altruista attitüdök megléte, a társadalom bizonyos csoportjai iránti hűség révén csökkentik az egyén 
elvándorlási hajlandóságát. A Hűség_ország és Hűség_település változók előjele, valamint 0,01 alatti p-értéke minden regresszióban igazolja ezt. Ráadásul az eredmények azt is mutatják, hogy az országhoz való kötődés a településhez való kötődésnél erősebb ellenösztönzőkkel szolgál a migrációhoz.

A Kisebbségi létet leíró változó - amely a (IV.3) specifikációban erősen szignifikánsnak bizonyult - előjele azonban eltér a várakozásainktól. Míg Simon (1993) alapján azt vártuk, hogy a kisebbségi csoporthoz való tartozás az altruista kötődések miatt mérsékeli az elvándorlási szándékokat, az eredmény ennek ellenkezőjét mutatja. Az eltérés oka vélhetően abban keresendő, hogy a kisebbségi léttel járó további hatások dominálják a simoni gondolat alapján megfogalmazottakat. Ilyen tényező lehet, hogy a kisebbségi lét már eleve abból fakad, hogy az illető bevándorlóként él jelenlegi lakhelyén, DaVanzo (1981a; 1981b) alapján azonban tudjuk, hogy a korábbi migrációs tapasztalat nagyban emeli az ismételt vándorlás valószínüségét. Emellett a kisebbségek tagjai olykor a társadalom perifériájára szorulnak, ami a szegénység révén szintén ösztönzőleg hathat a kivándorlásra. Annál is inkább, ha az - összhangban elméleti modellünk altruizmusra vonatkozó feltevéseivel - a hazautalások révén az otthonmaradó családtagok jólétének növekedéséhez járulhat hozzá. ${ }^{98}$

Az empirikus specifikációk különböző változatainak értékelésekor megállapítható, hogy az itt becsült modellek pszeudo R-négyzetei - abszolút értelemben nem magasak ugyan - de rendre nagyobbak az első vizsgálatban látottakénál. Ezen belül az altruista kapcsolatok proxy változóinak beemelése minimálisan ugyan, de javított a modellek magyarázó erején: a (III) specifikációhoz képest a (IV) specifikáció pszeudo Rnégyzete 0,02-dal, a (IV.3) specifikációé pedig 0,021-del nőtt. Az e lépések során beemelt változók együttes szignifikanciáját likelihood ratio teszttel vizsgáltuk, amelyek minden esetben 0,01 alatti p-értéket mutattak. E próbák eredményeit az 5.7. melléklet tartalmazza.

A különböző specifikációk mintán belüli predikciós képessége minden esetben gyengébb, mint az első vizsgálatban, azonban összességében még így is magasnak mondható. Az 5.4. táblázatban látható sorrendben a modellek helyes predikciós aránya rendre $89,48,89,86,89,27,89,45,89,66,89,82$, illetve 89,82 százalék. E téren a legjobb mutatóval tehát a (IV) specifikáció rendelkezik. A G tesztek eredményei - amelyet az 5.8.

\footnotetext{
${ }^{98}$ A kisebbségi létre vonatkozó eredményeink arra mutatnak rá, hogy komplex jelenséggel állunk szemben - mint ahogy a kisebbségi lét is rendkívül különböző státusszal és jellemzőkkel járhat a különböző országokban és helyzetekben. Így ennek részletes vizsgálata és tárgyalása túlmutat jelen disszertáció keretein.
} 
melléklet foglal össze - ugyancsak azt erősítik meg, hogy az általunk használt specifikációk egy konstans modellnél jobb becslést adnak a migrációs potenciál alakulására.

Az illeszkedést a Hosmer-Lemeshow teszttel is vizsgáltuk. Ezek eredményeit az 5.9. melléklet tartalmazza. A próbák elvégzése során csak a (IV.1) és (IV.2) specifikációk esetén tapasztaltunk a szokásos szignifikancia szintek melletti szignifikáns eredményt. Ez az említett becslések kivételével a többi esetben megfelelö illeszkedésre utal.

A link tesztek eredményei, amelyeket az 5.10. mellékletben foglaltunk össze, többnyire hasonló mintázatot követnek. Ezek a szokásos szignifikancia szintek mellett csak a (IV.1) és (IV.3) specifikációk esetén utalnak valamilyen esetleges specifikációs problémára.

A multikollineritás létét minden specifikáció esetén a VIF mutatók segítségével vizsgáltuk, amiről az 5.11. mellékletben adunk áttekintést. Ez a Kor és az Iskola változókra - hasonlóan az első vizsgálathoz - valamennyi modellben magas értéket mutatott, ám az ott leírt érvek alapján ezt most sem tekintjük problémának. Hasonló a helyzet a Hűség_ország és Hűség_település változók esetén: noha e két változó is erősen korrelál egymással, sem az elméleti modell, sem az empíriában mutatott szignifikanciájuk alapján nem látjuk indokoltnak valamelyikük elhagyását. A Relatív változó magas VIF mutatójának értékelése ugyanakkor eltér az előzőekétől. Azt már a korábbi diszkusszió során jeleztük, hogy e változó csak akkor bizonyult szignifikánsnak, ha az anyagi helyzet másik kontrollváltozója nem szerepelt a specifikációban. A pedig, hogy a Relatív változó emellett még rendre kritikus érték feletti VIF mutatót is produkált (ráadásul nem is csak azokban a specifikációkban, melyben az Anyagi is szerepelt), egy újabb érv lehet az elhagyása alapján. Mindezek alapján az Anyagi változót tekinthetjük alkalmasabbnak az anyagi helyzetre való kontrollálásra.

Az elvégzett illeszkedés-, illetve modelldiagnosztikai vizsgálatok alapján a (IV) specifikációt ítéljük a legjobbnak. Ezért a továbbiakban elemzésünket e specifikáció továbbvitelével folytatjuk. A modell robusztusságának tesztelése érdekében - az első vizsgálathoz hasonló módon - itt is külön becsléseket készítünk a régi és az új tagállamok almintáin. Ezt követően a (IV) specifikáció segítségével a tmigr ${ }^{2010}$ tisztított migrációs potenciál változóra készítünk becslést. Végül a (IV.4) specifikációban ország dummykat vonunk be a modellbe, hogy segítségükkel a különböző országspecifikus hatásokra tudjunk kontrollálni. Ezen regressziók eredményeit az 5.5. táblázat tartalmazza. 
5.5. táblázat

A migrációs hajlandóságot meghatározó tényezők az EU állampolgárai körében (2010). A (IV) specifikációjú becslés speciális eseteinek (régi és új tagállamok mintája, tisztított migrációs potenciál), illetve a (IV.4) specifikációjú logit modell marginális hatásai

(IV) Régi tagállamok

(IV) Új tagállamok

\begin{tabular}{lcccc} 
Hálózat_rokon & $0.0123 * * *$ & $(0.00368)$ & $0.0246 * * *$ & $(0.00397)$ \\
Hálózat_barát & $0.0389 * * *$ & $(0.00397)$ & $0.0388 * * *$ & $(0.00419)$ \\
Hálózat_munka & $0.0299 * * *$ & $(0.00559)$ & $0.0328 * * *$ & $(0.00700)$ \\
Hálózat_iskola & $0.0228 * * *$ & $(0.00616)$ & -0.00245 & $(0.00585)$ \\
Hálózat_élet & $0.0284 * * *$ & $(0.00623)$ & $0.0312 * * *$ & $(0.00861)$ \\
Hálózat_szabadság & $0.0246 * * *$ & $(0.00402)$ & -0.00248 & $(0.00408)$ \\
Internet & $0.00205 * *$ & $(0.000816)$ & $0.00400 * * *$ & $(0.000822)$ \\
Nyelv & 0.00521 & $(0.00352)$ & $0.0232 * * *$ & $(0.00367)$ \\
Ingatlan & $-0.0114 * * *$ & $(0.00362)$ & $-0.0145 * * *$ & $(0.00433)$ \\
Partnerrel & $0.0115 * *$ & $(0.00564)$ & $0.0114 *$ & $(0.00597)$ \\
Egyedülálló & $0.0178 * * *$ & $(0.00518)$ & $0.0264 * * *$ & $(0.00681)$ \\
Elvált & $0.0149 * *$ & $(0.00729)$ & $0.0179 * *$ & $(0.00860)$ \\
Özvegy & 0.00366 & $(0.0102)$ & 0.0202 & $(0.0146)$ \\
Gyermek & $-0.00829 * * *$ & $(0.00183)$ & $-0.00425 * *$ & $(0.00180)$ \\
Nem & $0.00978 * * *$ & $(0.00312)$ & 0.00384 & $(0.00315)$ \\
Kor & $-0.00154 * * *$ & $(0.000158)$ & $-0.00217 * * *$ & $(0.000199)$ \\
Falu & $-0.0134 * * *$ & $(0.00357)$ & $-0.00817 * *$ & $(0.00377)$ \\
Kisváros & -0.00553 & $(0.00347)$ & 0.000541 & $(0.00357)$ \\
Iskola & $0.000739 * * *$ & $(0.000275)$ & $0.00101 * *$ & $(0.000510)$ \\
Önfoglalkoztató & 0.00471 & $(0.00621)$ & 0.00115 & $(0.00640)$ \\
Foglalkoztatott_kékgalléros & 0.00524 & $(0.00460)$ & $0.0148 * *$ & $(0.00595)$ \\
Munkanélküli & 0.00543 & $(0.00528)$ & $0.0264 * * *$ & $(0.00678)$ \\
Nyugdíjas & $-0.0196 * * *$ & $(0.00567)$ & -0.00569 & $(0.00792)$ \\
Tanuló & $0.0583 * * *$ & $(0.0110)$ & $0.0319 * * *$ & $(0.00921)$ \\
Anyagi & $0.0165 * * *$ & $(0.00263)$ & $0.0128 * * *$ & $(0.00225)$ \\
Hüség_ország & $-0.0214 * * *$ & $(0.00231)$ & $-0.0192 * * *$ & $(0.00260)$ \\
Hüség_település & $-0.0133 * * *$ & $(0.00199)$ & $-0.00557 * *$ & $(0.00226)$ \\
N & 0.266 & & 9,960 & \\
Pszeudo R-négyzet & & & & 0.316 \\
\hline Robus)
\end{tabular}

Robusztus standard hibák zárójelben.

$* * * \mathrm{p}<0.01, * * \mathrm{p}<0.05, * \mathrm{p}<0.1$

Referenciacsoportokat meghatározó változók: Házas, Nagyváros,

Foglalkoztatott_fehérgalléros.

Forrás: saját számítás European Commission (2012d) alapján 


\section{5. táblázat (folyt.)}

(IV) Tisztított migrációs potenciál

(IV.4)

\begin{tabular}{|c|c|c|c|c|}
\hline Hálózat_rokon & $0.00381 * * *$ & $(0.000925)$ & $0.0148 * * *$ & $(0.00254)$ \\
\hline Hálózat_barát & $0.00906^{* * *}$ & $(0.00115)$ & $0.0344 * * *$ & $(0.00274)$ \\
\hline Hálózat_munka & $0.00400 * * *$ & $(0.00122)$ & $0.0321 * * *$ & $(0.00429)$ \\
\hline Hálózat_iskola & 0.000394 & $(0.00110)$ & $0.0140 * * *$ & $(0.00436)$ \\
\hline Hálózat_élet & $0.00590 * * *$ & $(0.00164)$ & $0.0235 * * *$ & $(0.00452)$ \\
\hline Hálózat_szabadság & $0.00339 * * *$ & $(0.000951)$ & $0.0241 * * *$ & $(0.00352)$ \\
\hline Internet & $0.000749 * * *$ & $(0.000206)$ & $0.00295 * * *$ & $(0.000558)$ \\
\hline Nyelv & $0.00398 * * *$ & $(0.000919)$ & $0.00910 * * *$ & $(0.00264)$ \\
\hline Ingatlan & $-0.00198 * *$ & $(0.000850)$ & $-0.0108 * * *$ & $(0.00263)$ \\
\hline Partnerrel & 0.00103 & $(0.00123)$ & $0.0109 * * *$ & $(0.00401)$ \\
\hline Egyedülálló & $0.00223 *$ & $(0.00123)$ & $0.0210 * * *$ & (0.00394) \\
\hline Elvált & 0.00197 & $(0.00174)$ & $0.0133 * *$ & $(0.00518)$ \\
\hline Özvegy & 0.000160 & $(0.00278)$ & 0.00613 & $(0.00755)$ \\
\hline Gyermek & $-0.00155^{* * *}$ & $(0.000464)$ & $-0.00689 * * *$ & $(0.00125)$ \\
\hline Nem & 0.000977 & $(0.000702)$ & $0.00683 * * *$ & $(0.00213)$ \\
\hline Kor & $-0.000321 * * *$ & $(4.19 \mathrm{e}-05)$ & $-0.00166 * * *$ & $(0.000118)$ \\
\hline Falu & $-0.00321 * * *$ & $(0.000844)$ & $-0.00923 * * *$ & $(0.00254)$ \\
\hline Kisváros & -0.000929 & $(0.000765)$ & -0.00217 & $(0.00244)$ \\
\hline Iskola & $1.63 \mathrm{e}-05$ & $(8.25 \mathrm{e}-05)$ & $0.000512 * *$ & $(0.000233)$ \\
\hline Önfoglalkoztató & $4.93 e-05$ & $(0.00151)$ & 0.00711 & $(0.00470)$ \\
\hline Foglalkoztatott_kékgalléros & 0.00106 & $(0.00121)$ & $0.00624 *$ & $(0.00336)$ \\
\hline Munkanélküli & $0.00541 * * *$ & $(0.00162)$ & $0.0121 * * *$ & $(0.00384)$ \\
\hline Nyugdíjas & -0.00210 & $(0.00170)$ & $-0.0146 * * *$ & $(0.00426)$ \\
\hline Tanuló & $0.00829 * * *$ & $(0.00229)$ & $0.0467 * * *$ & $(0.00721)$ \\
\hline Anyagi & $0.00430 * * *$ & $(0.000576)$ & $0.0114 * * *$ & $(0.00170)$ \\
\hline Hüség_ország & $-0.00308 * * *$ & $(0.000586)$ & $-0.0217 * * *$ & $(0.00172)$ \\
\hline Hüség_település & $-0.00130 * *$ & $(0.000505)$ & $-0.0111 * * *$ & $(0.00144)$ \\
\hline $\mathrm{N}$ & \multicolumn{2}{|c|}{24,734} & \multicolumn{2}{|c|}{24,239} \\
\hline Pszeudo R-négyzet & \multicolumn{2}{|c|}{0.245} & \multicolumn{2}{|c|}{0.308} \\
\hline
\end{tabular}

Robusztus standard hibák zárójelben.

$* * * \mathrm{p}<0.01, * * \mathrm{p}<0.05, * \mathrm{p}<0.1$

Referenciacsoportokat meghatározó változók: Házas, Nagyváros, Foglalkoztatott_fehérgalléros. A (IV.4) specifikáció ország dummykat is tartalmaz. A regresszió teljes, az ország dummykhoz tartozó marginális hatásokat is tartalmazó outputja az 5.12. mellékletben található.

Forrás: saját számitás European Commission (2012d) alapján

A korábbi eredmények robusztusságára utal, hogy az 5.5. táblázatban látható változók előjelei és p-értékei nagy százalékban hasonlítanak a megelőző specifikációk esetén tapasztaltakhoz. A migrációs hálózat létét, valamint az Internethasználat gyakoriságát jelző változók valamennyi regresszióban megfelelő előjellel és 0,01 alatti pértékkel szerepelnek, s a Nyelv változó is mindössze egy esetben, a régi tagállamok almintáján veszítette el a szignifikanciáját. Mindez pedig ismételten megerösíti a tranzakciós költségek szerepére vonatkozó feltevésünket. A településtípust jelző dummyk esetén az előző specifikációk becslésével megegyező eredményeket kaptunk. Hasonló 
következtetés vonható le a specifikus beruházásokkal kapcsolatban is: az Ingatlan változó szignifikanciája töretlen, a családi állapotot jelző dummyk p-értéke pedig nagyobb ugyan a korábban tapasztaltaknál, a szokásos szignifikanciaszintek mellett csak a Partnerrel ás az Elvált változók váltak inszignifikánssá, s ezek is kizárólag a tisztított migrációs potenciál becslésekor. A Gyermek változó a korábbiakkal megegyező előjellel, s 0,01 alatti p-értékkel szerepel valamennyi regresszióban.

Az alapvető demográfiai jellemzők kapcsán kissé árnyaltabb a kép. A p-értékek több esetben is emelkedtek, a Nem változó pedig az új tagállamok almintáján és a tisztított migrációs potenciál becslésekor elveszítette a szignifikanciáját, s utóbbi esetben az Iskola változóról is ugyanez mondható el. A Kor befolyásoló szerepe kapcsán ugyanakkor nem tapasztalhatunk érdemi eltéréseket. A munkaerőpiaci aktivitásra kontrolláló dummyk a szokásos szignifikancia szintek mellett több esetben inszignifikánssá váltak. Mindazonáltal az kiemelendő, hogy az Anyagi változó mellett mindkét altruizmus proxyra, a Hűség_ország és Hűség_város változókra vonatkozó eredményeink robusztusnak bizonyultak.

Az ország dummykat tartalmazó modell pszeudo R-négyzet mutatója az adott nagyságrendek mellett érdemben, 0,028-del magasabb a (IV) specifikációénál, ráadásul a predikciós képessége $(90,31 \%)$ is jobb. Az ország dummyk beemelésének indokoltságát a likelihood ratio test eredménye - lásd 5.7. melléklet - is alátámasztja. Emellett, noha a Hosmer-Lemeshow teszt értéke 10 százalékon szignifikánsnak bizonyult (lásd 5.9. melléklet), a link teszt eredményei nem utalnak specifikációs hibára (lásd 5.10. melléklet). Mindez jelen vizsgálat esetén is azt erősíti meg - tekintve, hogy az ország dummyk jelentős része is szignifikánsnak bizonyult -, hogy az elvándorlási kedvet bizonyos országspecifikus hatások is érdemben befolyásolják.

Az eddigi - jelentősen azonos irányba mutató - eredmények robusztusságát végül egy rendezett logit modell segítségével is teszteljük. Ehhez a (IV) specifikációban használt magyarázó változókon regresszáljuk a 4.3. alfejezetben definiált mmigr 2010 változót, amely az elvándorlás valószínűségét négyfokozatú skálán méri. Ezen becslés eredményeit, a korábbi gyakorlattól eltérően, a jobb áttekinthetőség kedvéért ezúttal az együtthatókat közölve, az 5.6. táblázatban foglaljuk össze. Az eredményváltozó különböző kimenetei szerinti marginális hatásokról az 5.13. melléklet ad áttekintést. 

(2010). A (IV) specifikációjú rendezett (ordered) logit modell együtthatói

(IV) rendezett logit

\begin{tabular}{|c|c|c|}
\hline Hálózat_rokon & $0.310 * * *$ & $(0.0353)$ \\
\hline Hálózat_barát & $0.645 * * *$ & $(0.0344)$ \\
\hline Hálózat_munka & $0.461 * * *$ & $(0.0471)$ \\
\hline Hálózat_iskola & $0.181 * * *$ & $(0.0589)$ \\
\hline Hálózat_élet & $0.424 * * *$ & $(0.0559)$ \\
\hline Hálózat_szabadság & $0.306 * * *$ & $(0.0379)$ \\
\hline Internet & $0.0877 * * *$ & $(0.00834)$ \\
\hline Nyelv & $0.423 * * *$ & $(0.0350)$ \\
\hline Ingatlan & $-0.174 * * *$ & $(0.0370)$ \\
\hline Partnerrel & $0.253 * * *$ & $(0.0502)$ \\
\hline Egyedülálló & $0.325 * * *$ & $(0.0478)$ \\
\hline Elvált & $0.390 * * *$ & $(0.0620)$ \\
\hline Özvegy & 0.0273 & $(0.0998)$ \\
\hline Gyermek & $-0.113 * * *$ & $(0.0184)$ \\
\hline Nem & $0.245 * * *$ & $(0.0323)$ \\
\hline Kor & $-0.0442 * * *$ & $(0.00173)$ \\
\hline Falu & $-0.235^{* * *}$ & $(0.0401)$ \\
\hline Kisváros & -0.0263 & $(0.0381)$ \\
\hline Iskola & $0.0285^{* * *}$ & $(0.00345)$ \\
\hline Önfoglalkoztató & 0.0920 & $(0.0601)$ \\
\hline Foglalkoztatott_kékgalléros & 0.0245 & $(0.0457)$ \\
\hline Munkanélküli & $0.103 * *$ & $(0.0512)$ \\
\hline Nyugdíjas & $-0.448 * * *$ & $(0.0672)$ \\
\hline Tanuló & $0.495 * * *$ & $(0.0633)$ \\
\hline Anyagi & $0.263 * * *$ & $(0.0262)$ \\
\hline Hüség_ország & $-0.388 * * *$ & $(0.0267)$ \\
\hline Hüség_település & $-0.215^{* * *}$ & $(0.0228)$ \\
\hline Konstans 1 & $-1.433^{* * *}$ & $(0.152)$ \\
\hline Konstans2 & $0.339 * *$ & $(0.152)$ \\
\hline Konstans3 & $1.998 * * *$ & $(0.154)$ \\
\hline $\mathrm{N}$ & \multicolumn{2}{|c|}{24,239} \\
\hline Pszeudo R-négyzet & \multicolumn{2}{|c|}{0.217} \\
\hline
\end{tabular}

Robusztus standard hibák zárójelben.

$* * * \mathrm{p}<0.01, * * \mathrm{p}<0.05, * \mathrm{p}<0.1$

Referenciacsoportokat meghatározó változók: Házas,

Nagyváros, Foglalkoztatott_fehérgalléros.

Forrás: saját számítás European Commission (2012d) alapján

Az eredmények összhangban vannak a korábbiakkal: az eddig rendre szignifikánsnak bizonyuló változók a rendezett logit modellben is azok maradtak, s az előjelük is megfelel mind a várakozásoknak, mind a korábban tapasztaltaknak. Kiemelendö, hogy a különbözö kimeneteket jellemzö konstansok is statisztikailag szignifikánsan különböznek egymástól, ami az itt használt kategóriák megtartásának 
indokoltságát támasztja alá. Noha a regresszió pszeudo R-négyzete az eddigiekhez képest alacsonyabb, az eredményváltozó becsült értékei - a Cameron \& Trivedi (2009) által javasolt modelldiagnosztikai eljárást alkalmazva - összhangban vannak az egyes kimenetek eredeti mintában történő gyakorisági arányaival. Erről az 5.14. melléklet ad áttekintést.

Összességében tehát azt láttuk, hogy a második vizsgálat eredményei igazolták jelentős részben robusztusan - az egyes változókra vonatkozó várakozásainkat, ráadásul az első vizsgálatban tapasztaltakkal is összhangban voltak. Mindezek összevetésére, az azonosságok és az esetleges különbségek áttekintésére a következő alfejezetben kerül sor.

\subsection{Empirikus eredmények összegzése}

Az empirikus vizsgálatok külön-külön történő lefolytatása után jelen alfejezetben ezek eredményeit összegezzük. Ehhez a rendezőelvet a Bevezetésben megfogalmazott hipotéziseink jelentik.

A H1 hipotézis alapján az intézmények minőségük és müködésük révén befolyásolják az egyén migrációs szándékait. Ezt az első vizsgálatban az intézményekbe vetett bizalom, valamint az informális intézményrendszerek között meghúzódó különbségek proxyzásával teszteltük. Az intézményi bizalommal kapcsolatos várakozásaink beigazolódtak: azok, akik bíztak származási országuk intézményeiben, valamennyi specifikációban ceteris paribus kisebb migrációs hajlandóságot mutattak. Az informális intézmények szerepére vonatkozó eredmények is közel ilyen robusztusok, igaz ezek szignifikáns hatását az új tagállamok almintáján, illetve a tisztított migrációs potenciál esetén nem sikerült igazolni. Előbbi esetben ez azzal lehet magyarázható, hogy ezen országcsoport esetén más - a modellben szereplő vagy esetleg a vizsgálaton kívül eső - tényezők dominánsabb alakítói a migrációs szándékoknak. A tisztított migrációs potenciál esetén az vezethetett a szignifikancia elvesztéséhez, hogy ezen eredményváltozó alá a potenciális migránsoknak csak egy szükebb csoportja volt besorolható - olyanok, akik valóban komoly elvándorlási szándékkal rendelkeztek. Így az vélelmezhető, hogy az informális intézmények közötti különbségek a nagy átlagok szintjén valóban elbizonytalaníthatják a migrációt fontolgatókat, a komoly szándékokkal rendelkező egyének esetében azonban már nincs jelentősebb hatásuk a tervekre.

A H2 hipotézis szerint azok, akik a migráció, illetve az azt megelőző keresés során több tranzakciós költséggel szembesülnek, magára az elvándorlásra is kevésbé lesznek hajlamosak. Tekintve, hogy e tranzakciós költségek mértékét a migrációs hálózatok, az 
infokommunikációs technológia adta lehetőségekhez való hozzáférés, illetve a nyelvismeret is befolyásolták, ezekre vonatkozó változókat mindkét vizsgálatban szerepeltettünk. Az eredmények mindhárom változócsoport esetén alátámasztották a hipotézisben foglaltakat, s többségében robusztusnak is mutatkoztak. Mindkét vizsgálat eredményei azt mutatták, hogy a migrációs hálózatok megléte érdemi pozitív irányú hatást gyakorol a kivándorlási kedv alakítására s a közel két tucat specifikáció során csak egy-egy esetben fordult elö, hogy az - összesen hét - erre vonatkozó változó valamelyike elveszítette szignifikanciáját. A nyelvtudás és az internethozzáférés szerepéről, illetve az ezekre vonatkozó empíriáról ugyanez mondható el. Így összességében, bár az említett tényezöket a két vizsgálatban rendre különböző változókkal proxyztuk, az általuk nyert eredmények összhangban vannak, s a tranzakciós költségekre vonatkozó hipotézisünk támogatása felé mutatnak.

Részben a tranzakciós költségek, részben az idioszinkrázia mértékét hivatottak proxyzni a válaszadó lakhelyének típusát jelölő dummyk is, a kapcsolat azonban mindkét esetben csak közvetett. Mindazonáltal modelljeink alapján az egyértelmüen kijelenthetö, hogy a nagyvárosi emberekhez képest falvak és kivárosok lakói szignifikánsan kevésbé hajlamosak az elvándorlásra. A kisebb városok lakóiról azonban ezt jobbára csak az első vizsgálat eredményei támasztották alá. Így a településtípusra vonatkozó eredmények áttételes hatásuk révén is csak részben támogatják a $\mathrm{H} 2$ és $\mathrm{H} 3$ hipotézist.

A specifikus beruházások H3 hipotézisben megfogalmazott szerepével kapcsolatban az empíria árnyalt képet mutat. Ennek egyik jele, hogy a helyspecifikus eszközként definiált saját ingatlan szignifikáns ellenösztönző hatását a migrációra csak a második vizsgálat igazolta, jóllehet, abban robusztusan. Ezzel szemben az első vizsgálat - ugyanúgy megfogalmazott kérdés alapján konstruált - Ingatlan változója csak néhány esetben bizonyult szignifikánsnak, s akkor is csak 90 százalékos konfidencia intervallum mellett. E különbözőség oka az elvégzett vizsgálatokban nem rajzolódott ki egyértelműen, de a szándékok komolyságának foka (ti. az első vizsgálat eredményváltozójának konstruálásához használt kérdés erősebb migrációs szándékra vonatkozott) lehetséges magyarázatként szolgálhat. Ugyanilyen vizsgálatok közötti mintázat volt megfigyelhető a Gyermekszámra vonatkozó változó esetében is. Itt persze magával a változó-választással szemben megfogalmazhatók fenntartások: az, hogy a gyermekekkel szembeni kapcsolat idioszinkratikus jellege elméleti szinten is csak akkor lehet ellenösztönzője a kivándorlásnak, ha előbbiek a származási országban maradnak, vagy ha a kivándorlásnak nem pont a róluk való, hazautalások révén történő gondoskodás 
a célja. Ezen ellenvetések azonban az első vizsgálatban tapasztalt vegyes eredményeket csak az adott vizsgálaton belül képesek magyarázni, a második vizsgálattal való összevetésben - ahol az eredmények abszolút robusztusok - már nem. Így a két vizsgálatban tapasztalt különbözőségekre - a véletlenen túl - e téren is a szándék komolyságában fellelhető eltérések révén tudunk lehetséges magyarázatot adni. A családi állapot kapcsán ugyanakkor nagyobb az összhang a két vizsgálat eredményei között. Modelljeink szinte kivétel nélkül igazolták, hogy a párkapcsolatban, s különösen annak intézményesített, tehát még idioszinkratikusabb formájában élő személyek ceteris paribus kevésbé hajlamosak az elvándorlásra, ami egybeesik a hipotézisben foglaltakkal. Külön említendő még itt is az idegennyelv-tudás szerepe, mivel az is egy indikátora a humántőke országspecifikusságának. Mint azt már jeleztük, az erre vonatkozó eredmények többnyire robusztusan alátámasztották várakozásainkat.

A specifikusság szempontjai ezen felül bizonyos mértékben a munkaerő-piaci státusszal is összefüggésbe hozhatók. Ezek kapcsán többnyire támogató, de vegyes mintázat rajzolódik ki az elvégzett vizsgálatokban. Közös pont, hogy a munkanélküli, illetve a tanulói létre utaló dummyk mindkét vizsgálat specifikációinak zömében pozitív előjellel szignifikánsnak bizonyultak. Ebben pedig a klasszikus jövedelmi ösztönzőn túl a munkahely viszonylatában eszközölt relációspecifikus beruházások visszatartó erejének a hiánya is szerepet játszhat. A további dummyk kapcsán ugyanakkor a két vizsgálat eltérő képet mutat. Az első vizsgálatban jobbára az Önfoglalkoztatók, a másodikban pedig a kékgalléros foglalkoztatottak produkáltak szignifikáns eredményeket. Az értelmezést nehezíti, hogy mindkét csoport nagyobb mobilitási hajlandóságot mutatott a referenciacsoportként használt fehérgalléros foglalkoztatottakkal szemben. Mindez összességében arra enged következtetni, hogy a valódi „,határvonalakat” nem az általunk használt kategorizálás adja, s az érdemi különbségek - például a specifikusság szempontjából is - a munkahellyel rendelkező és nem rendelkező személyek között vannak. Végül megjegyzendő az is, hogy nyugdíjasok kizárólag a második vizsgálatban mutatkoztak szignifikánsan immobilabbnak (igaz, ott szinte minden specifikációban). Ezen szignifikáns hatások azonban nagy valószínüséggel nem a specifikusság valamely aspektusával, hanem a nyugdíjas lét egyéb jellegzetességeivel magyarázhatók.

A H4 hipotézis szerint az altruista attitüdökkel rendelkezők mások jólétével is törődnek, ez pedig egy hűségként manifesztálódó kötődést hoz létre, ami ellenösztönzője lehet a kivándorlásnak. Ezt - különböző formában - mindkét vizsgálatban teszteltük, s a Lelki költség, Hűség_ország, Hűség_település változók eredményei robusztusan 
alátámasztották az állításunkat. Az altruizmus forrásaként is nevesített családi kapcsolatokra utaló változóink - mint azt már összegeztük - vegyes, de a várakozásokkal többnyire egybevágó képet mutattak. A Kisebbségi változó ugyanakkor nem várt eredményt hozott, ám ez inkább a nem megfelelő proxy választás tényére utal. Noha a szakirodalmi és elméleti feltevések alapján e változót is negatív előjellel vártuk a becslésbe, az ezzel ellentétes eredmények arra hívták fel a figyelmet, hogy a kisebbségi léttel számos olyan egyéb tényező jár együtt, amelyek dominálják az altruizmus révén feltételezett ellenösztönző hatást.

A további, az egyén nemére, korára, iskolázottságára és anyagi helyzetére vonatkozó kontrollváltozók mindkét vizsgálatban egységes képet mutatnak: a változók előjelei megegyeznek mind az irodalmi áttekintésben bemutatott eredményekkel, mind az elmélet alapján vártakkal, s egy-egy kivételtől eltekintve rendre szignifikánsnak is bizonyultak. Ezek közül vizsgálatunk szempontjából a Kor változó emelhető ki, méghozzá azért, mert az idősödéssel párhuzamosan az egyén egyre több specifikus beruházást eszközöl. Eredményeink alapján természetesen nem tudjuk azt állítani, hogy ez az általunk felvetett összefüggés dominálja vagy felülírja azon további, a korosodással járó hatásokat, amelyeket a korábbi irodalmak nyomán tárgyaltunk, ugyanakkor az eredmények nem is mondanak ellent e hipotézisünknek. 


\section{KORLÁTOK ÉS KITEKINTÉS}

Disszertációnk célja egy komplex elméleti modellt felépítése és egy körültekintő empirikus vizsgálatot lefolytatása volt, ugyanakkor a kutatás során több korláttal is szembesültünk. Emellett több további kutatásra érdemes szempont és irány is felvetődött munkánk során, kifejtésük azonban meghaladta volna a disszertáció kereteit. Jelen fejezetben ezekről a korlátokról és továbblépési lehetőségekről adunk áttekintést.

Elméleti modellünkkel kapcsolatban kiemelhető az, ami bármilyen modellezés esetén fennáll: egy modell mindig csak egyszerüsített képét adja a valóságnak. Ez a migrációs döntés kapcsán is elmondható, még akkor is, ha modellünkkel igyekeztünk egy relatíve komplex képet adni az elvándorlást befolyásoló tényezőkről. Mindez természetesen nem jelenti azt, hogy modellünket kizárólagosnak gondolnánk: elismerjük, hogy az - szükségszerüen - nem tartalmazhat minden befolyásoló tényezőt, s azt is elfogadjuk, hogy bizonyos aspektusokat más irányzatok akár mélyebben is tárgyalnak. Példaként említhetők erre az érzelmek: noha fontos eredménynek tekintjük, hogy az altruizmus segítségével az érzelmi kötődéseket egy formalizált közgazdasági modellbe sikerült beépítenünk, nem vitatjuk, hogy az érzelmek komplex természete miatt erről az aspektusról bizonyos pszichológiai megközelítések részletesebb képet adnak.

Empirikus vizsgálatunk kapcsán ugyancsak említhetők ilyen szempontok. Amint azt a 3. fejezetben tárgyaltuk, a migrációkutatásban a megfelelő adatbázis megtalálása jelenti az egyik fó kihívást. Noha az ott bemutatott érvek és hivatkozott szakirodalmak alapján a migrációs hajlandóságra vonatkozó adatok használatát megfelelőnek ítéltük jelen vizsgálat lefolytatásához, bizonyos korlátokra érdemes itt is felhívni a figyelmet. Mivel a migráció szándékának megjelenése a tényleges elvándorlás előszobájának, szükséges, de nem elégséges feltételének tekinthető, ezért az általunk szignifikánsnak talált tényezők a tényleges migrációs döntésben is szerepet játszhatnak. Mivel azonban addig több hátráltató tényező is adódhat ${ }^{99}$, ezek némelyike veszíthet súlyábó1 ${ }^{100}$, illetve új szempontok is felmerülhetnek. Különösen igaz ez akkor, ha az időtáv, amelyen az egyén a potenciális migrációról gondolkozik, hosszú. Ennek megfelelően az, hogy az

\footnotetext{
${ }^{99}$ A hátráltató tényezőkről - más megközelítésben - lásd Carling \& Schewel (2018) kétlépcsős modelljét. ${ }^{100}$ Erre lehet példa első vizsgálatunkban, hogy míg az informális intézmények okozta különbségek a nyers migrációs potenciál esetén szignifikáns ellenösztönzöként jelentek meg, addig ilyen szignifikáns hatást a tisztított migrációs potenciállal végzett vizsgálat esetén már nem tapasztalhattunk. Mindez ugyanakkor inkább arra mutat rá, hogy az, amit a korábbi közgazdasági modellek egy „egyszeri” döntésként írtak le, valójában egy gondolkodási folyamat eredménye, $\mathrm{s}$ végül a migráció (vagy a helyben maradás) e folyamat „produktumaként” értelmezhető.
} 
általunk használt kérdőívek kérdései 5, illetve 10 éves horizontra vonatkoztak, némiképp gyengíthette az eredmények érvényességét. Mindezek tükrében különösen fontos, hogy hipotéziseinket szilárd és plauzibilis elméleti modellel támasztottuk alá, ugyanakkor az eredmények validitásának és robusztusságának további ellenőrzésére érdekében célszerü lehet - amennyiben a jövőben erre lehetőség nyílik - a hipotéziseket tényleges migrációra vonatkozó adatokon is tesztelni. Szintén a további vizsgálatok célszerüsége mellett szólhat, hogy adataink a 2008-as, illetve 2010-es évekből származnak, amelyek a válság miatt speciális éveknek tekinthetők. ${ }^{101}$ Amennyiben más adatfelvételekben eltérő migrációs mintázatok figyelhetők meg az országok szintjén (jóllehet, vizsgálatunk fókuszában az egyéni, s nem az országos szint áll), az ugyancsak további vizsgálatok célszerüségét indokolhatja. Más országok mintáján végzett további vizsgálatok figyelembe véve az EU-s intézményi környezet sajátosságait - szintén hozzájárulhatnak az eredmények robusztusságának teszteléséhez.

Bár a disszertáció fókuszában a nemzetközi migráció állt, az irodalmi áttekintésben említettük, hogy ennek tárgyalása a korai szakirodalomban nem vált el élesen a belső migrációtól. Noha a két jelenség közti hasonlóságok és különbségek részletes tárgyalása kívül esik jelen disszertáció fókuszán, az - ismételten megjegyzendő, hogy az alapvető különbséget a vándorlás intézményi környezete adja. Ennek kapcsán nem csak arra az egyszerü tényre gondolhatunk, hogy míg a nemzetközi migráció egy többnyire szabályozott aktus, addig az országon belüli vándorlás kevésbé. Az eltérő intézmények megismerése, a hozzájuk való alkalmazkodás ugyanis költségeket jelent a migráns számára. Ez a formális intézményrendszer (például az országhatárok átlépésével járó szabályoknak, a bevándorláspolitikai és munkavállalási rendelkezéseknek való megfelelés; a fogadó ország jogrendjének a megismerése stb.) és az első vizsgálatunkban külön változóként szerepeltetett informális intézmények (eltérő kulturális normákhoz, konvenciókhoz való igazodás, amelyek olykor még a formális szabályoknál nehezebben is ismerhetők meg vagy „sajátíthatók el) kapcsán egyaránt fennáll. Az intézményi különbségeken túl - amelynek részletes tárgyalása, beleértve a konkrét intézményeket is, külön kutatás tárgya lehet - az általunk használt intézményi közgazdaságtani koncepciókkal megragadható befolyásoló tényezők vonatkozásában is megfogalmazhatók gondolatok. Ezek többsége ugyanis vélhetően eltérő erővel hat a belső

\footnotetext{
101 Ezen szempont kapcsán azonban továbbra is hangsúlyozandó, hogy vizsgálatunk nem egy empirikus problémára kíván reflektálni, hanem általános modellt építettünk, amelynek válság- és válság nélküli években egyaránt alkalmazhatónak kell lennie.
} 
és a nemzetközi migráció esetében. A kereséssel járó tranzakciós költségek általában alacsonyabbak lehetnek az országhatáron belüli mozgás esetén, ám kiemelendő, hogy az infokommunikációs technológiához való hozzáférés mind a külső, mind a belső migráció esetén jelentős költségcsökkentő tényezőként jelentkezhet. Az egyén humántőkéjének országspecifikusságát is mérő nyelvtudás megléte jobbára csak a külföldre vándorlás esetén játszhat szerepet (többek között pont abban, hogy az imént említett tranzakciós költségek mértékét csökkentse). A helyspecifikus eszköznek tekintett ingatlan tulajdonlása sok esetben az országhatárokon belül is immobilissá teheti a polgárokat. ${ }^{102}$ A hüség révén jelentkező lelki költségek alapvetően inkább a távolsággal arányosan növekedhetnek, bár egy országhatár átlépése vonhat maga után olyan - a tökéletes racionalitás talaján kívül eső - érzelmeket, ami így többletteherként jelentkezhet. Ezen feltevések empirikus tesztelése ugyanakkor külön kutatást érdemel (figyelembe véve akár a különböző országok és az eltérő történelmi helyzetek sajátosságait is).

Disszertációnk bevezetésében a migrációt mint tartós letelepedési és/vagy munkavégzési célú, önkéntes, országhatáron átnyúló lakhelyváltoztatást határoztuk meg. Az általános jellegü definiálás oka az volt, hogy a migrációnak nem valamely speciális fajtájáról, hanem a jelenségről általában kívántunk gondolkodni. Mindazonáltal az, hogy az egyes, ezen belül értelmezhető migrációtípusok (például munkavállalási célzatú, nyugdíjaskori letelepedési célú, visszatérő vagy ismételt migráció, családegyesítési célú) között felfedezhetö-e valamilyen különbség az általunk vizsgált befolyásoló tényezők „erősségében”, további kutatás tárgyát képezheti. Ugyanez mondható el a definíción kívül eső mobilitási formák (például menekült vándorlás, ingázás vagy cirkuláris migráció) kapcsán is. Egy ilyen vizsgálat ugyanis - amennyiben érdemi különbségeket tárna fel fontos adalékokkal szolgálna az egyes migrációs és mobilitási formák különbözőségének a megértéséhez.

Elemzésünk ugyanakkor nem csak ebben az irányban mélyíthető. Az általunk használt változók akár egymással, akár ország dumykkal vett interakciói további információkkal szolgálhatnak az egyes hatások természete mellett bizonyos empirikus jelenségek magyarázatára is.

Ahogyan azt a Bevezetésben jeleztük, célunk egy analitikus modell építése volt, s a történeti megközelítést mellőztük disszertációban. Elvitathatatlan azonban, hogy a társadalmi cselekvések nem értelmezhetők tértől és időtől függetlenül. Az országok

102 Jó példa erre Magyarország esete, ahol az ingatlantulajdonlást az alacsony munkaerőmobilitás fő okai között tartják számon (Sebök, 2016). 
migrációs mintázatait többek között a történelmi múltjuk is befolyásolja. Emellett a migrációnak eltérő történelmi helyzetben eltérő mozgatórugói is lehetnek. Noha empirikus vizsgálatainkban az ország dummyk használatával kontrolláltunk bizonyos országonkénti fix hatásokra (ideértve többek között a történelmi helyzetből adódó tényezőket), mindennek a részletes tárgyalása az eltérő kutatási cél okán kívül esett jelen disszertáció fókuszán. Tekintve ugyanakkor, hogy a történeti szemlélet további fontos adalékokkal szolgálhat többek között az intézmények vagy más intézményi közgazdaságtani tényezők alakulásának megértéséhez, ezt a megközelítést is fontos iránynak tartjuk, amely későbbi kutatások tárgya lehet. 


\section{KONKLÚZIÓ}

Jelen disszertáció arra a kérdésre kereste a választ, hogy a migráció neoklasszikus mikroökonómiai modelljében szereplő tényezőkön túl milyen intézményi és viselkedési közgazdaságtani motívumok befolyásolják az egyéni szintű elvándorlási döntéseket. E kérdés megválaszolása, valamint a hozzá megfogalmazott hipotézisek tesztelése érdekében először áttekintettük a vonatkozó szakirodalmat, hogy abban elhelyezzük saját munkánkat. Ezután felépítettük intézményi közgazdaságtani megalapozottságú elméleti modellünket, amit annak empirikus tesztelése követett.

Elvégzett vizsgálatunk eredményei azonos irányba mutatnak a hipotéziseinkben foglaltakkal:

H1 hipotézisünk szerint az országok intézményrendszereinek minösége befolyásolja az egyén kivándorlási hajlandóságát. A származási ország jó intézményrendszere marasztaló, míg a rossz intézményrendszer taszitó hatással bír a potenciális migránsokra. Empirikus elemzésünk alapján elvethetjük azt az ellenhipotézist, hogy a származási ország intézményrendszerének a minősége nincs hatással az egyén kivándorlási hajlandóságának alakulására. Elméleti modellünkben felvázoltuk, hogy az intézmények fó funkciója a bizonytalanság csökkentése, s amennyiben az egyén bízik abban, hogy az intézmények betöltik e funkciójukat, úgy hosszabb távon is kiszámíthatóbbnak érzi jövőjét az adott országban. Az erre vonatkozó eredményeink a várakozásnak megfelelően alakultak, s robusztusnak bizonyultak. Ezen túlmenően azt is megmutattuk, hogy az informális intézményekben meghúzódó különbségek is ellenösztönzői lehetnek a kivándorlásnak: azok, akik az eltérő kultúrához való alkalmazkodást nehézségként élték volna meg, ceteris paribus kisebb elvándorlási hajlandóságot mutattak.

H2 hipotézisünk szerint a tranzakciós költségek mértéke, amellyel az egyén a keresés, illetve a migráció megvalósitása során szembesül, befolyásolja a kivándorlási hajlandóságát. A tranzakciós költségek mértéke és a kivándorlási hajlandóság között negatív irányú kapcsolatot áll fent. Empirikus vizsgálatunk alapján azt az ellenhipotézist is elvethetjük, hogy a tranzakciós költségek mértéke, mellyel az egyén szembesül, nem befolyásolja a migrációs hajlandóságot. Mint azt elméleti modellünkben felvázoltuk, a migrációs első lépése egy keresési folyamat, s az, hogy ennek során az egyén mennyi tranzakciós költséggel szembesül, meghatározhatja, hogy milyen alternatívát tud találni a 
helyben maradással szemben. A kevesebb tranzakciós költség folyománya lehet, hogy a potenciális migráns többet tud keresni, s nagyobb eséllyel lel rá egy jó elvándorlási lehetőségre. Empirikus elemzésünk is ezt mutatta meg: a migrációs hálózattal rendelkezők, az idegennyelveket beszélők, az internethasználók, illetve a nagyvárosok lakói nagyobb migrációs potenciállal bírtak, mint a vonatkozó referenciacsoportok tagjai.

H3 hipotézisünk szerint a specifikus beruházások léte és mértéke befolyásolja az egyén kivándorlási hajlandóságát. A specifikus beruházások mértéke és a kivándorlási hajlandóság között negatív irányú kapcsolat áll fent. Empirikus vizsgálatunk alapján elvethetjük azt az alternatív hipotézist, hogy a specifikus beruházások megléte és mértéke nem befolyásolja a migrációs hajlandóságot. Az idioszinkrázia fontos jellemzője a piaci kapcsolatoknak, befolyásolja azok tartósságát. A kapcsolatba fektetett specifikus beruházások ugyanis annak felszámolásával elsüllyedt költséggé válnának, így a feleknek nem éri meg a partnerváltás. Elméleti modellünkben amellett érveltünk, hogy az egyén származási országa irányába is tehet - bár nem feltétlenül tudatosan - ilyen specifikus beruházásokat. Noha egyes kapcsolatok komplex természete tükrében az eredményeink árnyalása szükséges, több ponton is arra mutatnak rá, hogy az idioszinkrázia jelenléte visszatartó erő lehet a kivándorlástól. Erre utaló eredményeket az ingatlantulajdonlással, az egyén humántőkéjének országspecifikusságával, a településtípusa révén meglévő beágyazottságával, illetve az idioszinkratikus kapcsolatokat teremtő családi vonatkozásaival összefüggésben is tapasztaltunk.

H4 hipotézisünk szerint az egyén altruizmusából fakadó lelki költségek léte és mértéke befolyásolja a kivándorlási hajlandóságát. Az altruista kapcsolatok, illetve az ebböl fakadó lelki költségek mértéke és a kivándorlási hajlandóság között negatív irányú kapcsolat áll fent. Empirikus eredményeink alapján elvethetjük azt az ellenhipotézist, hogy az altruizmuson keresztül jelentkező lelki költségek nem befolyásolják az egyén kivándorlási hajlandóságát. Az elvándorlás révén manifesztálódó lelki költségeket, s az ennek nyomán jelentkező hűséget az altruizmus segítségével vezettünk be elméleti modellünkbe. Amellett érveltünk, hogy a hozzátartozói jólétével is törődő altruista hűségessé válik meglévő közösségei irányába, s tartózkodik a kivándorlástól, ha azzal ront előbbiek jólétén. Az erre vonatkozó empirikus eredményeink robusztusnak mutatkoztak: az országuk, illetve városuk társadalma iránt hűséggel viseltetők ceteris paribus kisebb migrációs hajlandóságot mutattak. Ugyanez mondható el első vizsgálatunk alapján azokról is, akinek a hozzátartozókkal való kapcsolattartás hiánya kihívást jelentett volna a migráció esetén. 
Munkánk mind a gyakorlat, mind a tudomány szempontjából fontos adalékokkal, implikációkkal bír.

Irodalmi áttekintésünk érdemi hozzájárulással szolgál a migrációkutatáshoz. A migrációs elméleteket újszerű struktúrában, széles alapon dolgoztuk fel, úgy, hogy abban napjaink valóban kurrens irányzataira helyeztük a hangsúlyt. Egy ilyen áttekintésre - saját munkánk viszonyítása mellett - a szakirodalomban fellelhető „sablonosság” miatt volt szükség. A migrációs kutatásokban ugyanis rendszeresen visszaköszönő elem, hogy azok jelentős része kizárólag Massey és mtsai (1993) áttekintésére épít. Bár a hivatkozott tanulmány elvitathatatlan erényekkel rendelkezik, egyúttal „gúzsba is köti” a kutatók egy részének a kezét az elméletek struktúrája és irodalmi bázisa tekintetében. Ráadásul a mü több, mint negyedszázaddal ezelőtt keletkezett, amely szükségszerủen nélkülözi az azóta született vívmányokat, illetve arra sem tud reflektálni, hogy bizonyos irányzatok ez idő alatt a partvonalra szorultak a tudományt müvelők körében.

Az elméletek tesztelésére szolgáló empirikus irodalmakról is széleskörü és alapos áttekintést készítettünk. Szisztematikus és jól áttekinthető rendszerezésünknek köszönhetően ez referenciapontot, egyfajta „térképet” adhat a további kutatások számára. Azzal, hogy ezt az elméleti irodalmaktól elkülönítve tárgyaltuk, az elemzési szintek eltérőségében meglévő problematikusságra is hangsúlyt helyeztünk, ami ugyancsak mintaként szolgálhat a jövőbeni kutatások számára.

Az általunk épített intézményi közgazdaságtani megközelítésü modell mind a közgazdaság-tudományi, mind a migrációs szakirodalom szemszögéből fontos implikációkkal bír. Előbbi szempontjából az intézményi közgazdaságtan alkalmazhatóságával kapcsolatban hordoz üzenetet. Ez az irányzat a közgazdaságtudomány egyik legdinamikusabban fejlődő, s a fóáramba is egyre inkább beépülő iskolájának mondható. Jelen disszertációban azt mutattuk meg, hogy az intézményi közgazdaságtan vívmányai az üzleti kapcsolatok, a tranzakciók megszervezési módjának, a politikai berendezkedés hatásainak vagy a gazdasági teljesítmény meghatározottságának magyarázata mellett egy új területen, a migrációs döntést befolyásoló tényezők leírására is sikerrel alkalmazhatók.

A migrációkutatás vonatkozásában ennek újszerüsége abban ragadható meg, hogy egy ebben a kontextusban korábban még nem használt megközelítésmóddal írtuk le az egyén elvándorlási döntését. Ez a fogalomkészlet ráadásul amellett, hogy a korábban szétszórtan, más tudományterületek irodalmában meglévő ismeretanyagot tudott egy 
egységes közgazdasági modellbe integrálni, új tényezőkkel is szolgált a migrációs hajlandóság természetének megértéséhez.

Noha a közgazdaság-tudomány egy jelentős részében ma már közhely, hogy az intézmények számítanak, a migrációkutatás közgazdaságtani ága korábban nem tett kísérletet arra, hogy az intézmények egyéni szintü migrációs döntésre gyakorolt hatását értelmezze. Jelen disszertáció elméleti modelljében erre vállalkoztunk. Az empirikus elemzésben ugyanezt tettük. Szemben a korábban felsejlő példákkal, amelyek a makro elemzési szintü indikátorokkal próbálták vizsgálni az intézmények szerepét, itt újszerü módon ezt egy mikroszintü tényező, az intézményi bizalom segítségével teszteltük. Ezzel az intézmények - egyéni döntésben ténylegesen megjelenő - bizonytalanságcsökkentő funkciójának a migrációs hajlandóságra gyakorolt hatására helyeztük a hangsúlyt.

Az intézményi bizalom migrációs kontextusban történő értelmezése révén Győrffy (2012) modelljét is kibővítettük. Míg utóbbi zárt rendszert feltételezett, amelyben a rossz intézményekre a szabályszegés lehetett az egyén legszélsőségesebb válasza, disszertációnkban arra mutattunk rá, hogy a diszfunkcionális intézményi müködés nyitott kontextusban az elvándorlást, az adott intézményi környezetből való kilépést is maga után vonhatja.

Az intézményi minőség érdemi szerepével kapcsolatos eredményeink közpolitikai implikációkkal is bírnak. Rámutatnak, hogy azon származási országok kormányzatai, melyeket az elvándorlás negatívan érint, nem csak a reálgazdasági tényezők rögös útnak tekinthető javításával (például bérek felzárkózása) védekezhetnek a jelenség ellen. A kiszámíthatóbb jövőt ígérő, s a polgárok által is megbízhatóbbnak ítélt intézményi környezet kialakítása szintén képes lehet fékezni a folyamatot.

Az intézményi közgazdaságtan megközelítésével egy integratív modellt építettünk fel, amely korábban egymással kevéssé kompatibilis, illetve nem a közgazdaság-tudomány nyelvén megfogalmazott állításokat foglalt össze egy egységes keretbe. Modellünk tehát közgazdasági, de más tudományterületröl érkező eredményeket is integrál ebbe a keretbe. A migráció tranzakciós költségeit az intézményi közgazdaságtan által megkövetelt fogalmi pontosság kritériumainak megfelelően, tranzakcióhoz kapcsolva választottuk le az elvándorlás egyéb, standard költségeiröl. Ennek, s az általunk épített kétlépcsős modellnek a segítségével tudtuk kompakt módon operacionalizálni korábban más diszciplinák fogalomkészletével (migrációs hálózatok megléte), vagy egyszerüen kvázi-közhelyszerü evidenciaként (internethasználat, idegennyelv-ismeret) értelmezett hatásokat. 
Hasonló hozzájárulási eredmény fogalmazható meg a specifikusság koncepciójával kapcsolatban is. Segítségével olyan tényezőket tudtunk formalizálni, illetve a közgazdaság-tudomány nyelvén értelmezni (például az ingatlantulajdonlást vagy a családi kötődéseket), amelyek fontosságát a korábbi irodalmak is elismerték, ám Speare (1971) szerint a hagyományos költség-haszon logikában lehetetlen volt hozzáadni őket a közgazdasági modellhez, így jobbára a megmagyarázatlan eltérésekként aposztrofálták őket. Emellett a humántőke országspecifikusságának dimenziójának hozzáadásával az eredeti humántőke elmélet gondolatait is mélyítettük.

Az altruista attitüdön keresztül jelentkező hüség modellbe építésével valódi, újszerü tartalmat adtunk a migrációs irodalomban oly fontosnak tartott, korábban azonban nem formalizált, s nem valódi erőforrás-költségként számontartott lelki költségeknek. Ezek interdependens preferenciák segítségével történő modellezésére eddig nem volt példa az irodalomban, pedig e megközelítés az egyén kötődéseinek a különböző szituációkban történő értelmezésére is lehetőséget ad. Modellünkben ugyanazzal az altruizmus-koncepcióval magyarázható, ha az egyént a hozzátartozóinak okozandó lelki fájdalmak tartják vissza a kivándorlástól, mint ahogy az is, ha valaki éppen azért dönt a migráció mellett, hogy szeretteit többlet forrásokhoz juttassa. Mindezt a Hirschman-féle hüségkoncepcióval is összekötöttük, amelynek ekként történő formalizálása ugyancsak újdonság a migrációs irodalomban.

Mindez egyúttal a helyben maradás rejtvényének megoldásához - s ezáltal a neoklasszikus megközelítés hiányosságainak mérsékléséhez - is adalékokkal szolgált. Az általunk visszatartó tényezőkként azonosított faktorok ugyanis a kivándorlási hajlandóság ceteris paribus csökkentése mellett arra is rávilágítottak, hogy milyen csatornán keresztül tehetnek bizonyos jellemzők irrelevánssá bizonyos társadalmi csoportokat a migráció szempontjából.

Modellünk abban is túllép a hagyományos közgazdaság-tudományi megközelítésen, hogy a migrációt a gondolat felmerülésétől az aktus megvalósulásáig folyamatként, s nem egy időben pontszerü, diszkrét döntésként értelmezi. Noha más diszciplínákban találhatunk példát ilyen kétlépcsős modellekre (Carling \& Schewel, 2018; Speare, 1974), a formalizált mikroökonómiai alapú modellek körében ez újszerünek tekinthető.

Empirikus vizsgálatunk az irodalomban szokásos eljárásokat követte. Becsléseinkben ugyanakkor szerepeltettünk olyan változókat (intézményekbe vetett bizalom; országhoz, illetve városhoz való kötődés, informális intézményi különbégektől, 
valamint a lelki költségek megjelenésétől való félelem), amelyek ebben a formában a korábbi vizsgálatokban nem jelentek meg. Több korábban is használt változót pedig mint azt már jelent fejezetben is részleteztük - újszerü jelentéstartalommal töltöttünk fel.

Végül, de nem utolsó sorban az adatokkal kapcsolatos kihívások és dilemmák rendszerezett bemutatása is fontos hozzájárulásnak tekinthetö. Diszkussziónk kiindulási pontként szolgálhat a migráció kutatásába kezdők számára, hiszen az empirikus elemzés gyakorlatában lépésről lépésre felmerülő kérdésenként vezeti végig az olvasót a kihívásokon és a hozzájuk kapcsolódó válaszlehetőségeken. 


\section{FELHASZNÁLT IRODALOM}

Acemoglu, D., \& Robinson, J. A. (2013). Miért buknak el nemzetek? A hatalom, a jólét és a szegénység eredete. Budapest: HVG Kiadó.

Acemoglu, D., Johnson, S., \& Robinson, J. A. (2001). The colonial origins of comparative development: An empirical investigation. American Economic Review, 91(5), 1369-1401.

Acemoglu, D., Johnson, S., \& Robinson, J. A. (2005). Institutions as a Fundamental Cause of Long-Run Growth. In P. Aghion, \& S. N. Durlauf, Handbook of Economic Growth, Volume 1A (385-472. o.). North Holland.

Ahmad, N., Hussain, Z., Sial, M. H., Hussain, I., \& Akram, W. (2008). Macroeconomic determinants of international migration from Pakistan. Pakistan Economic and Social Review, 46(2), 85-99.

Akerlof, G. A. (1970). The Market for "Lemons": Quality uncertainty and the market mechanism. The Quarterly Journal of Economics, 84(3), 488-500.

Andor László (2014). Munkaerö-mobilitás az EU-bővítés után. Közgazdasági Szemle, 61(4), 363-372.

Arkes, H. R., \& Blumer, C. (1985). The Psychology of Sunk Cost. Organizational Behavior and Human Decision Processes, 35, 124-140.

Arrow, K. J. (1969). The organization of economic activity: issues pertinent to the choice of market versus nonmarket allocation. In The analysis and evaluation of public expenditure: the PPB system (1. kötet, 59-73. o.).

Bach, R. L., \& Smith, J. (1977). Community Satisfaction, Expectations of Moving, and Migration. Demography, 14(2), 147-167.

Banerjee, A. V. (1992). A Simple Model of Herd Behavior. The Quarterly Journal of Economics, 107(3), 797-817.

Bauer, T., \& Zimmermann, K. (1995). Modelling International Migration: Economic and Econometric Issues. In R. van der Erf, \& L. Heering, Causes of International Migration. Proceedings of a workshop. (95-115. o.). Luxembourg: Eurostat.

Bayer József (2019). A migráció globális trendje és politikai dilemmái. Magyar Tudomány, 180(1), 28-36.

Becker, G. S. (1962). Investment in Human Capital: A Theoretical Analysis. Journal of Political Economy, 70(5), 9-49. 
Becker, G. S. (1974). A Theory of Social Interactions. Journal of Political Economy, 82(6), 1063-1093.

Becker, G. S. (1976). Altruism, Egoism, and Genetic Fitness: Economics and Sociobiology. Journal of Economic Literature, 14(3), 817-826.

Ben-Porath, Y. (1980). The F-Connection: Families, Friends, and Firms and the Organization of Exchange. Population and Development Review, 6(1), 1-30.

Bertocchi, G., \& Strozzi, C. (2008). International migration and the role of institutions. Public Choice, 137(1-2), 81-102.

Blanchflower, D. G., Saleheen, J., \& Shadforth, C. (2007). The Impact of the Recent Migration from Eastern Europe on the UK Economy. IZA Discussion Paper No. 2615., Letöltve: http://anon-ftp.iza.org/dp2615.pdf (2017.11.03.).

Blaskó Zsuzsa \& Gödri Irén (2014). Kivándorlás Magyarországról: Szelekció és célország-választás az "új migránsok" körében. Demográfia, 57(4), 271-307.

Blaskó Zsuzsa., Ligeti Anna Sára, \& Sik Endre (2014). Magyarok külföldön - Mennyien? Kik? Hol? In Kolosi Tamás \& Tóth István György, Társadalmi Riport 2014 (351372. o.). Budapest: TÁRKI.

Boda Zsolt (2016). Intézményi bizalom és a közpolitikák eredményessége. In Boda Zsolt, Bizalom és közpolitika. Jobban müködnek-e az intézmények, ha biznak bennük? (7-21. o.). Budapest: Argumentum; MTA Társadalomtudományi Kutatóközpont Politikatudományi Intézet.

Boda Zsolt \& Medve-Bálint Gergő (2012). Intézményi bizalom a régi és az új demokráciákban. Politikatudományi Szemle, 21(2), 27-51.

Bodenhöfer, H.-J. (1967). The Mobility of Labor and the Theory of Human Capital. The Journal of Human Resources, 2(4), 431-448.

Borjas, G. J. (1989). Economic Theory and International Migration. The International Migration Review, 23(3), 457-485.

Borjas, G. J. (1991). Immigration and Self-Selection. In J. M. Abowd, \& R. B. Freeman, Immigration, Trade, and the Labor Market (29-76. o.). Chicago: University of Chicago Press.

Borjas, G. J. (2014). Immigration Economics. Cambridge: Harvard University Press.

Böheim, R., \& Taylor, M. P. (2002). Tied Down or Room to Move? Investigating the Relationships Between Housing Tenure, Employment Status and Residential Mobility in Britain. Scottish Journal of Political Economy, 49(4), 369-392. 
Böhme, M. H., Gröger, A., \& Stöhr, T. (2019). Searching for a better life: Predicting international migration with online search keywords. Journal of Development Economics, Online First, 1-14.

Burda, M. C., Härdle, W., Müller, M., \& Werwatz, A. (1998). Semiparametric Analysis of German East-West Migration Intentions: Facts and Theory. Journal of Applied Econometrics, 13(5), 525-541.

Burgess, K. (2012). Migrants, Remittances, and Politics: Loyalty and Voice after Exit. The Fletcher Forum of World Affairs, 36(1), 43-55.

Cameron, C. A., \& Trivedi, P. K. (2009). Microeconometrics Using Stata. College Station: Stata Press.

Capuano, S., \& Migali, S. (2017). The migration of professionals within the EU: Any barriers left? Review of International Economics, 25(4), 760-773.

Carling, J., \& Collins, F. (2018). Aspiration, desire and drivers of migration. Journal of Ethnic and Migration Studies, 44(6), 909-926.

Carling, J., \& Schewel, K. (2018). Revisiting aspiration and ability in international migration. Journal of Ethnic and Migration Studies, 44(6), 945-963.

Carrington, W. J., Detragiache, E., \& Vishwanath, T. (1996). Migration with Endogenous Moving Costs. The American Economic Review, 86(4), 909-930.

Castro-Martín, T., \& Cortina, C. (2015). Demographic Issues of Intra-European Migration: Destinations, Family and Settlement. European Journal of Population, $31(2), 109-125$.

Choi, Y. B. (1993). Paradigms and Conventions. Uncertainty, Decision Making, and Entrepreneurship. Ann Arbor: The Universitiy of Michigan Press.

Clark, X., Hatton, T. J., \& Williamson, J. G. (2007). Explaining U.S. immigration, 19711998. The Review of Economics and Statistics, 89(2), 359-373.

Coase, R. H. (1937). The Nature of the Firm. Economica, 4(16), 386-405.

Coase, R. H. (1960). The Problem of Social Cost. The Journal of Law \& Economics, 3, $1-44$.

Coleman, J. S. (1988). Social capital in the creation of human capital. American Journal of Sociology, 94, S95-S120.

Collins, F. L. (2018). Desire as a theory for migration studies: temporality, assemblage and becoming in the narratives of migrants. Journal of Ethnic and Migration Studies, 44(6), 964-980. 
Czaika, M. (2015). Migration and Economic Prospects. Journal of Ethnic and Migration Studies, 41(1), 58-82.

Csaba László (2019). Globalizáció, migráció, Európai Unió. Bevezető. Magyar Tudomány, 180(1), 3-9.

Dahlman, C. J. (1979). The Problem of Externality. The Journal of Law \& Economics, 22(1), 141-162.

DaVanzo, J. (1978). Does Unemployment Affect Migration? Evidence from Micro Data. The Review of Economics and Statistics, 60(4), 504-514.

DaVanzo, J. (1981a). Microeconomic Approaches to Studying Migration Decisions. In G. F. De Jong, \& R. W. Gardner, Migration Decision Making. Multidisciplinary Approaches to Microlevel Studies in Developed and Developing Countries (90129. o.). New York: Pergamon Press.

DaVanzo, J. (1981b). Repeat Migration, Information Costs, and Location-Specific Capital. Population and Environment, 4(1), 45-73.

David, P. A. (1974). Fortune, Risk, and the Microeconomics of Migration. In P. A. David, \& M. W. Reder, Nations and Households in Economic Growth. Essays in Honor of Moses Abramovitz (21-88. o.). New York: Academic Press.

De Jong, G. F., \& Fawcett, J. T. (1981). Motivations for Migration: An Assessment and a Value-Expectancy Research Model. In G. F. De Jong, \& R. W. Gardner, Migration Decision Making. Multidisciplinary Approaches to Microlevel Studies in Developed and Developing Countries (13-58. o.). New York: Pergamon Press.

De Jong, G. F., Root, B. D., Gardner, R. W., Fawcett, J. T., \& Abad, R. G. (1986). Migration Intentions and Behavior: Decision Making in a Rural Philippine Province. Population and Environment, 8(1-2), 41-62.

Deaton, B. J., Morgan, L. C., \& Anschel, K. R. (1982). The Influence of Psychic Costs on Rural-Urban Migration. American Journal of Agricultural Economics, 64(2), 177-187.

Denzau, A. T., \& North, D. C. (1994). Shared Mental Models: Ideologies and Institutions. Kyklos, 47(1), 3-31.

Djajic, S., \& Milbourne, R. (1988). A General Equilibrium Model of Guest-Worker Migration. Journal of International Economics, 3-4, 335-351.

Dorigo, G., \& Tobler, W. (1983). Push-Pull Migration Laws. Annals of the Association of American Geographers, 73(1), 1-17. 
Drinkwater, S. (2003). Go West? Assessing the willingness to move from Central and Eastern European Countries. Flowenla Discussion Paper 5. Hamburg Institute of International Economics.

Letöltve: https://www.researchgate.net/profile/Stephen_Drinkwater/publication/24133994 _Go_West_Assessing_the_Willingness_to_Move_from_Central_and_Eastern_E uropean_Countries/links/0c96052f8d97874b7d000000.pdf (2019.07.22.)

Dustmann, C. (2003). Return Migration, Wage Differentials, and the Optimal Migration Duration. European Economic Review, 47(2), 353-369.

Edgeworth, F. Y. (1881). Mathematical Psychics: An Essay on the Application of Mathematics to the Moral Sciences. London: C. Kegan Paul \& Co.

Eggertsson, T. (1990). Economic behavior and institutions. Cambridge: Cambridge University Press.

Epstein, G. S. (2002). Informational Cascades and Decision to Migrate. IZA Discussion Paper No. 445, Letölve: https://www.econstor.eu/bitstream/10419/21511/1/dp445.pdf (2018.11.27.).

Epstein, G. S. (2008). Herd and Network Effects in Migration Decision-Making. Journal of Ethnic and Migration Studies, 34(4), 567-583.

Epstein, G. S., \& Gang, I. N. (2006). The Influence of Others on Migration Plans. Review of Development Economics, 10(4), 652-665.

Eriksson, T. (1989). International Migration and Regional Differentials in Unemployment and Wages: Some Empirical Evidence from Finland. In I. Gordon, \& A. P. Thirlwall, European Factor Mobility. Trends and Consequences (59-73. o.). London: Palgrave Macmillan.

European Commission \& European Parliament, Brussels. (2013). Eurobarometer 75.1 (2011). TNS OPINION \& SOCIAL, Brussels [Producer]. GESIS Data Archive, Cologne, ZA5479 Data file Version 6.0.0. Letöltve: http://dx.doi.org/10.4232/1.11646. (2018.08.20.)

European Commission \& European Parliament, Brussels. (2016). Eurobarometer 85.1OVR (April 2016). TNS opinion [producer]. GESIS Data Archive, Cologne, ZA6696 Data file Version 1.0.0. Letöltve: http://dx.doi.org/10.4232/1.12642 (2018.08.20.).

European Commission. (2012a). Eurobarometer 64.1 (Sep-Oct 2005). TNS OPINION \& SOCIAL, Brussels [Producer]. GESIS Data Archive, Cologne, ZA4413 Data file Version 1.1.0. Letöltve: http://dx.doi.org/10.4232/1.10969 (2018.08.20.). 
European Commission. (2012b). Eurobarometer 67.1 (Feb-Mar 2007). TNS OPINION \& SOCIAL, Brussels [Producer]. GESIS Data Archive, Cologne, ZA4529 Data file Version 3.0.1. Letöltve: http://dx.doi.org/10.4232/1.10983 (2018.08.20.).

European Commission. (2012c). Eurobarometer 70.1 (Oct-Nov 2008). TNS OPINION \& SOCIAL, Brussels [Producer]. GESIS Data Archive, Cologne, ZA4819 Data file Version 3.0.2. Letöltve: http://dx.doi.org/10.4232/1.10989 (2018.08.20.). Kérdőív: https://dbk.gesis.org/dbksearch/download.asp?db=E\&id=15932 (2018.08.20.) Adatbázis:

https://dbk.gesis.org/dbksearch/download.asp?db=E\&id=47571 (2018.08.20.)

European Commission. (2012d). Eurobarometer 73.3 (Mar-Apr 2010). TNS OPINION \& SOCIAL, Brussels [Producer]. GESIS Data Archive, Cologne, ZA5233 Data file Version 3.0.0. Letölve: http://dx.doi.org/10.4232/1.11430 (2018.08.20.. Kérdöív: https://dbk.gesis.org/dbksearch/download.asp?db=E\&id=19170 (2018.08.20.). Adatbázis: $\quad$ https://dbk.gesis.org/dbksearch/download.asp?db=E\&id=47673 (2018.08.20.).

European Commission. (2013). Eurobarometer 72.5 (Nov-Dec 2009). TNS OPINION \& SOCIAL, Brussels [Producer]. GESIS Data Archive, Cologne, ZA4999 Data file Version 5.1.0. Letölve: http://dx.doi.org/10.4232/1.11642 (2018.08.20.).

European Commission. (2016). Eurobarometer 79.2 (2013). TNS opinion, Brussels [producer]. GESIS Data Archive, Cologne, ZA5688 Data file Version 6.0.0. Letöltve: http://dx.doi.org/10.4232/1.12577 (2018.08.20.).

European Parliament \& DG Communication, Brussels. (2014). Flash Eurobarometer 395 (European Youth 2014). TNS Political \& Social [producer]. GESIS Data Archive, Cologne, ZA5908 Data file Version 1.0.0. Letöltve: http://dx.doi.org/10.4232/1.11995 (2018.08.20.).

Faini, R., \& Venturini, A. (2010). Development and Migration: Lessons from Southern Europe. In G. S. Epstein, \& I. N. Gang, Migration and Culture (Frontiers of Economics and Globalization, Volume 8) (105-136.). Emerald Group Publishing Limited. Letöltve: http://www.emeraldinsight.com/doi/book/10.1108/S1574$8715 \% 282010 \% 298$ (2017.12.12.):

Fassmann, H., \& Münz, R. (1997). A keleti nyitás következménye: munkaerő-vándorlás Kelet-Európából Nyugat-Európába. Külgazdaság, 41(10), 39-60.

Fawcett, J. T. (1985). Migration Psychology: New Behavioral Models. Population and Environment, 8(1), 5-14. 
Foster, A. D., \& Rosenzweig, M. R. (2001). Imperfect Commitment, Altruism, and the Family: Evidence from Transfer Behavior inLow-Income Rural Areas. The Review of Economics and Statistics, 83(3), 389-407.

Fouarge, D., \& Ester, P. (2008). How Willing are Europeans to Migrate? A Comparison of Migration Intentions in Western and Eastern Europe. In P. Ester, R. Muffels, J. Schippers, \& T. Wilthagen, Innovating European Labour Markets (49-71. o.). Cheltenham: Edward Elgar Publishing Limited.

Furubotn, E. G., \& Richter, R. (2005). Institutions and Economic Theory. The Contribution of the New Institutional Economics. Ann Arbor: The University of Michigan Press.

Fülöp Gábor, Csáfor Hajnalka, Nagy Levente \& Papanek Gábor (2016). Munkaerőhiány alacsony foglalkoztatás mellett. Versenyképességi kihívások a hevesi munkaerőpiacon és az oktatásban. Polgári Szemle, 12(4-6), 134-149.

Geary, P., \& Ó Gráda, C. (1989). Post-war Migration between Ireland and the United Kingdom: Models and Estimates. In I. Gordon, \& A. P. Thirlwall, European Factor Mobility. Trends and Consequences (53-58. o.). London: Palgrave Macmillan.

Geis, W., Uebelmesser, S., \& Werding, M. (2013). How do migrants choose their destination country? An Analysis of Institutional Determinants. Review of International Economics, 21(5), 825-840.

Golovics József (2015). A hallgatói szerződések közgazdaságtana. Sugo Szemle, 2(1), 104-111.

Golovics József (2015). Agyelszívás: egyensúly európai szinten? In Ferencz Árpád, II. Gazdálkodás és menedzsment tudományos konferencia. I. kötet (456-460. o.). Kecskemét: Kecskeméti Főiskola KIK Nyomda.

Golovics József (2016a). Agyelszívási adó az EU-ban: egy lehetséges megoldás? Külgazdaság, 60(11-12), 44-65.

Golovics József (2016b). Kivándorlás vagy maradás? A hűség szerepe a migrációs döntésekben. Competitio, 15(2), 3-21.

Golovics József (2018). Intézményi bizalom és elvándorlási hajlandóság. Educatio, 27(4), (Megjelenés alatt).

Golovics József (2019a). A nemzetközi migráció mozgatórugói: elmélet és empíria. Áttekintés. Demográfia (Megjelenés alatt) 
Golovics József (2019b). The role of loyalty in migration intentions: theory and evidence from the EU. Society and Economy. Online first, 1-21. Letöltve: http://akademiai.com/doi/pdf/10.1556/204.2019.010 (2019.07.18.).

Goodman, J. L. (1981). Information, Uncertainty, and the Microeconomic Model of Migration Decision Making. In G. F. De Jong, \& R. W. Gardner, Migration Decision Making. Multidisciplinary Approaches to Microlevel Studies in Developed and Developing Countries (130-148. o.). New York: Pergamon Press.

Goss, J., \& Lindquist, B. (1995). Conceptualizing International Labor Migration: A Structuration Perspective. The International Migration Review, 29(2), 317-351.

Gödri Irén (2015). Nemzetközi vándorlás. In Monostori Judit, Öri Péter \& Spéder Zsolt, Demográfiai portré 2015: Jelentés a magyar népesség helyzetéröl (187-211. o.). KSH Népességtudományi Kutatóintézet: Budapest.

Gödri Irén (2016). Elvándorlási szándékok - Álmok és konkrét tervek között. A migrációs potenciál jellemzöi és meghatározó tényezöi a 18-40 évesek körében Magyarországon. Kutatási jelentések 98. Budapest: KSH Népességtudományi Kutatóintézet. Letöltve: http://www.demografia.hu/kiadvanyokonline/index.php/kutatasijelentesek/articl e/download/2699/pdf (2019.07.22.)

Gödri Irén (2018). Nemzetközi vándorlás. In Monostori Judit, Öri Péter \& Spéder Zsolt, Demográfiai Portré 2018 (237-270. o.). Budapest: KSH Népességtudományi Kutatóintézet.

Gödri Irén \& Feleky Gábor Attila (2013). Migrációs tervek megvalósulása egy követéses vizsgálat tükrében. Az előzetes migrációs szándék, a várakozások és a külső elvárások szerepe. Demográfia, 56(4), 281-332.

Granovetter, M. (1985). Economic action and social structure: The problem of embeddedness. American Journal of Sociology, 91(3), 481-510.

Grogger, J., \& Hanson, G. H. (2011). Income maximization and the selection and sorting of international migrants. Journal of Development Economics, 95(1), 42-57.

Gurak, D. T., \& Caces, F. (1992). Migration Networks and the Shaping of Migration Systems. In M. M. Kritz, L. L. Lim, \& H. Zlotnik, International Migration Systems. A Global Approach (150-176. o.). Oxford: Oxford University Press.

Gustavus, S. O., \& Brown, L. A. (1977). Place attributes in a migration decision context. Environment and Planning, 9(5), 529-548. 
Győrffy Dóra (2012). Intézményi bizalom és a döntések időhorizontja. Közgazdasági Szemle, 59(4), 412-425.

Győrffy Dóra (2014). Bizalom és gazdaságpolitika: Fejezetek az euró történetéből. Akadémiai Doktori Értekezés. Budapest.

Győrffy Dóra (2017). Bizalom és pénzügyek. Válság és válságkezelés az Európai Unióban. Budapest: Typotex Kiadó.

Hagen-Zanker, J. (2008). Why do people migrate? A review of the theoretical literature.

MPRA Paper No. 28197, Letöltve: http://mpra.ub.uni-muenchen.de/28197/ (2016.02.24.).

Halász Levente (2018). A magyarok erősödő migrációjának makrogazdasági hatásai. In Siskáné Szilasi Beáta \& Halász Levente, Boldogulni itthon vagy külföldön. Legújabb trendek a magyarországi kivándorlásban (78-85. o.). Miskolc: Miskolci Egyetem Földrajz - Geoinformatika Intézet.

Hámori Balázs (1998). Érzelemgazdaságtan. A közgazdasági elemzés kiterjesztése. Budapest: Kossuth Kiadó.

Hámori Balázs (2013). Új szereplők és magatartásformák az átalakuló tranzakciós térben. Budapest: Akadémiai Doktori Értekezés.

Hardin, R. (1999). Do we want trust in government? In M. E. Warren, Democracy and Trust (22-41. o.). Cambridge: Cambridge University Press.

Harris, J. R., \& Todaro, M. P. (1970). Migration, Unemployment and Development: A Two-Sector Analysis. The American Economic Review, 60(1), 126-142.

Hárs Ágnes (2016). Elvándorlás, bevándorlás és a magyar munkaerőpiac. Jelenségek, hatások, lehetőségek. In Kolosi Tamás \& Tóth István György, Társadalmi Riport 2016 (243-262. o.). Budapest: TÁRKI.

Hárs Ágnes \& Simon Dávid (2016a). Miért mennek el az orvosok - és miért maradnának itthon? - II. rész. A magyarországi orvosmigráció sajátosságairól. Külgazdaság, 60(4), 3-26.

Hárs Ágnes \& Simon Dávid (2016b). Munkaerő-migráció, ingázás, kivándorlás. A magyarok munkavállalási célú emigrációját magyarázó tényezők hatása és változása az uniós csatlakozás óta. In Blaskó Zsuzsa \& Fazekas Károly, Munkaerőpiaci Tükör 2015 (72-85. o.). Budapest: MTA Közgazdaság- és Regionális Tudományi Kutatóközpont Közgazdaságtudományi Intézet.

Hárs Ágnes \& Simon Dávid (2017). A külföldi munkavállalás és a munkaerőhiány. In Fazekas Károly, \& Köllő János, Munkaerőpiaci Tükör 2016 (94-108. o.). 
Budapest: MTA Közgazdaság- és Regionális Tudományi Kutatóközpont Közgazdaság-tudományi Intézet.

Hart, O. (2006). Vállalatok, szerzödések és tökeszerkezet. Budapest: Nemzeti Tankönyvkiadó.

Hart, O. (2009). Hold-up, asset ownership, and reference points. The Quarterly Journal of Economics, 124(1), 267-300.

Hart, R. A. (1975). Interregional economic migration: some theoretical considerations (Part II). Journal of Regional Science, 15(3), 289-300.

Hartog, J., \& Vriend, N. (1989). Post-war International Labour Mobility: The Netherlands. In I. Gordon, \& A. P. Thirlwall, European Factor Mobility. Trends and Consequences (74-94. o.). London: Palgrave Macmillan.

Hatton, T. J. (2005). Explaining trends in UK immigration. Journal of Population Economics, 18(4), 719-740.

Haug, S. (2008). Migration Networks and Migration Decision-Making. Journal of Ethnic and Migration Studies, 34(4), 585-605.

Hayek, F. A. (1945). The use of knowledge in society. The American Economic Review, 35(4), 519-530.

Hayek, F. A. (1991). Út a szolgasághoz. Budapest: Közgazdasági és Jogi Könyvkiadó.

Helmke, G., \& Levitsky, S. (2004). Informal Institutions and Comparative Politics: A Research Agenda. Perspectives on Politics, 2(4), 725-740.

Hicks, J. R. (1963). The Theory of Wages. Second Edition. Palgrave Macmillan UK.

Hirschman, A. O. (1978). Exit, Voice, and the State. World Politics, 31(1), 90-107.

Hirschman, A. O. (1995). Kivonulás, tiltakozás, hüség. Budapest: Osiris Kiadó.

Hodgson, G. M. (2006). What Are Institutions? Journal of Economic Issues, 40(1), 1-25.

Hoffmann, B. (2010). Bringing Hirschman Back In: "Exit", "Voice", and "Loyalty" in the Politics of Transnational Migration. The Latin Americanist, 54(2), 57-73.

Huber, P., \& Nowotny, K. (2013). Moving across Borders: Who is Willing to Migrate or to Commute? Regional Studies, 47(9), 1462-1481.

Hunt, G. L., \& Mueller, R. E. (2004). North American Migration: Returns to Skill, Border Effects, and Mobility Costs. The Review of Economics and Statistics, 86(4), 9881007.

Hurd, I. (1999). Legitimacy and Authority in International Politics. International Organization, 53(2), 379-408. 
Huzdik Katalin (2014). Migrációs potenciál alakulása, és az azt befolyásoló tényezők a XXI. század első évtizedében Magyarországon. Doktori (PhD) értekezés, Szent István Egyetem.

Huzdik, K., Schwang, Z., \& Takács, I. (2010). Analysis of Employees Migration in Hungary. Zarzadzanie Publiczne, 1-2(9-10), 53-64.

Jenkins, J. C. (1977). Push/Pull in Recent Mexican Migration to the U.S. The International Migration Review, 11(2), 178-189.

Jennissen, R. (2003). Economic Determinants of Net International Migration in Western Europe. European Journal of Population, 19(2), 171-198.

Johnson, D. B. (1999). A közösségi döntések elmélete. Budapest: Osiris Kiadó.

Johnston, T. (2011). Voice after Exit? Remittances and Migration Across Authoritarian Regimes. UM Comparative Politics Workshop, January 28, 2011, Letöltve: https://sites.lsa.umich.edu/tsebelis/wpcontent/uploads/sites/223/2015/01/johnston.cpw2011.pdf (2017.11.02.).

Kahneman, D., \& Tversky, A. (1979). Prospect Theory: An Analysis of Decision under Risk. Econometrica, 47(2), 263-291.

Kahneman, D., Knetsch, J. L., \& Thaler, R. H. (1991). The Endowment Effect, Loss Aversion, and Status Quo Bias. The Journal of Economic Perspectives, 5(1), 93206.

Katseli, L. T., \& Glystos, N. P. (1989). Theoretical and Empirical Determinants of International Labour Mobility: A Greek-German Perspective. In I. Gordon, \& A. P. Thirlwall, European Factor Mobility. Trends and Consequences (95-115. o.). London: Palgrave Macmillan.

Katz, E., \& Stark, O. (1987). International Migration Under Asymmetric Information. The Economic Journal, 97(387), 718-726.

Kim, K., \& Cohen, J. E. (2010). Determinants of International Migration Flows to and from Industrialized Countries: A Panel Data Approach Beyond Gravity. International Migration Review, 44(4), 899-932.

Kiss Judit (2019). Tényekkel a migrációs tévhitek ellen: gondolatok Szentes Tamás A nemzetközi migráció ügye a szélsőséges nézetek tükrében című előadása kapcsán. Magyar Tudomány, 180(1), 53-66.

Knight, F. H. (1921). Risk, Uncertainity and Profit. Boston: Houghton Mifflin Company. Kőszegi, B., \& Rabin, M. (2009). Reference-dependent Consumption Plans. American Economic Review, 99(3), 909-936. 
Krugman, P., \& Bhagwati, J. (1976). The decision to migrate. A survey. In J. N. Bhagwati, The Brain Drain and Taxation II. Theory and Empirical Analysis (3151. o.). Amsterdam: North Holland.

Kureková, L. (2013). Welfare systems as emigration factor: Evidence from the new accession states. Journal of Common Market Studies, 51(4), 721-739.

Kutasi, G. (2005). Labour Migration and Competitiveness in the European Union. Transition Studies Review, 12(3), 512-526.

Lakatos Judit (2015). Külföldön dolgozó magyarok, Magyarországon dolgozó külföldiek. Statisztikai Szemle, 93(2), 93-112.

Landale, N. S., \& Guest, A. M. (1985). Constraints, Satisfaction and Residential Mobility: Speare's Model Reconsidered. Demography, 199-222.

Lee, E. S. (1966). A Theory of Migration. Demography, 3(1), 47-57.

Leventhal, G. S. (1980). What Should Be Done with Equity Theory? New Approaches to the Study of Fairness in Social Relationships. In K. J. Gergen, M. S. Greenberg, \& R. H. Willis, Social Exchange (27-55. o.). New York: Plenum Press.

Lewis, W. A. (1954). Economic development with unlimited supplies of labour. Manchester School of Economic and Social Studies, 22(2), 139-191.

Lowe, R., \& Ritchey, G. (1973). Relation of altruism to age, social class, and ethnic identity. Psychological Reports, 33(2), 567-572.

Lucas, R. E. (1977). Understanding business cycles. In K. Brunner, \& A. Meltzer, Stabilization of The Domestic International Economy, Vol. 5 (7-29. o.). NorthHolland.

Lundborg, P. (1991). Determinants of Migration in the Nordic Labor Market. The Scandinavian Journal of Economics, 93(3), 363-375.

Machina, M. J. (1987). Choice Under Uncertainty: Problems Solved and Unsolved. Journal of Economic Perspectives, 1(1), 121-154.

Maier, G. (1985). Cumulative causation and selectivity in labour market oriented migration. Regional Studies, 19(3), 231-241.

Massey, D. S. (1990a). The social and economic origins of immigration. Annals of the American Academy of Political and Social Scien, 510, 60-72.

Massey, D. S. (1990b). Social structure, household strategies, and the cumulative causation of migration. Population Index, 56(1), 3-26. 
Massey, D. S., Arango, J., Hugo, G., Kouaouci, A., Pellegrino, A., \& Taylor, E. J. (1993). Theories of International Migration: A Review and Appraisal. Population and Development Review, 19(3), 431-466.

Massey, D. S., Arango, J., Hugo, G., Kouaouci, A., Pellegrino, A., \& Taylor, J. E. (1998). Worlds in Motion. Understanding International Migration at the End of the Millenium. Oxford: Clarendon Press.

Masten, S. E., Meehan, J. W., \& Snyder, E. A. (1991). The Costs of Organization. Journal of Law, Economics, \& Organization, 7(1), 1-25.

Mayda, A. M. (2010). International migration: a panel data analysis of the determinants of bilateral flows. Journal of Population Economics, 23(4), 1249-1274.

Mike Károly (2008). Kivonulás, tiltakozás és hűség az Európai Unióban. A specifikus beruházások jelentősége. Századvég, 13(50), 79-106.

Mike Károly (2009). Adalékok a föderalizmus gazdaságtanához - Alkalmazásokkal az európai integrációra. Budapest: Ph.D. értekezés. Budapesti Corvinus Egyetem.

Mike, K. (2012). Hirschman Meets Williamson: Relationship-Specific Investment and Loyalty. Corvinus Journal of Sociology and Social Policy, 3(2), 55-81.

Milgrom, P., \& Roberts, J. (2005). Közgazdaságtan, szervezetelmélet és vállalatirányitás. Budapest: Nemzeti Tankönyvkiadó.

Mincer, J. (1958). Investment in Human Capital and Personal Income Distribution. Journal of Political Economy, 66(4), 281-302.

Mincer, J. (1978). Family Migration Decisions. Journal of Political Economy, 86(5), 749773.

Molho, I. (1986). Theories of Migration: A Review. Scottish Journal of Political Economy, 33(4), 396-419.

Molho, I. (2013). Theories of Migration: A Review. Scottish Journal of Political Economy, 60(5), 526-556.

Molle, W., \& van Mourik, A. (1989). A Static Explanatory Model of International Labour Migration to and in Western Europe. In I. Gordon, \& A. P. Thirlwall, European Factor Mobility. Trends and Consequences (13-29. o.). London: Palgrave Macmillan.

Morgan, L. C., \& Deaton, L. J. (1975). Psychic Cost and Factor Price Equalization. Southern Journal of Agricultural Economics, 7(1), 233-238.

Mulder, C. H., \& Wagner, M. (2012). Moving after Separation: The Role of Locationspecific Capital. Housing Studies, 27(6), 839-852. 
Musgrave, R. A. (1959). The Theory of Public Finance. New York: McGraw Hill.

Neszveda Gábor (2018). A kiszámíthatatlanság fokozatainak szerepe a közgazdaságtanban. Köz-Gazdaság, 13(4), 103-111.

Neumayer, E. (2004). Asylum Destination Choice. What Makes Some West European Countries More Attractive Than Others? European Union Politics, 5(2), 155-180.

Neyman, J. (2018). Logistic Regression. BIOSTAT 640. Letöltve: https://people.umass.edu/biep640w/pdf/5.\%20\%20Logistic\%20Regression\%202 018.pdf (2018.09.05).

Niehans, J. (1987). Transaction Costs. In P. Macmillan, The New Palgrave Dictionary of Economics. London: Palgrave Macmillan. Letöltve: https://link.springer.com/referenceworkentry/10.1057/978-1-349-95121-5_16821 (2018.07.01.).

North, D. C. (1987). Institutions, Transaction Costs and Economic Growth. Economic Inquiry, 25(3), 419-428.

North, D. C. (1990). A Transaction Cost Theory of Politics. Journal of Theoretical Politics, 2(4), 355-367.

North, D. C. (1991). Institutions. Journal of Economic Perspectives, 5(1), 97-112.

North, D. C. (2010). Intézmények, intézményi változás és gazdasági teljesitmény. Budapest: Helikon Kiadó.

North, D. C., Wallis, J. J., \& Weingast, B. R. (2009). Violence and Social Orders. A Conceptual Framework for Interpreting Recorded Human History. Cambridge: Cambridge University Press.

Örkény Antal (2003a). A migrációs potenciál szociodemográfiai okai a Kárpát-medencei magyarok körében. In Örkény Antal, Menni vagy maradni? Kedvezménytörvény és migrációs várakozások (150-187. o.). Budapest: MTA Kisebbségkutató Intézet.

Örkény Antal (2003b). A roma migrációs potenciál szociodemográfiai és etnikai okai. In Örkény Antal, Menni vagy maradni? Kedvezménytörvény és migrációs várakozások (223-229. o.). Budapest: MTA Kisebbségkutató Intézet.

Palmer, J., \& Pytlikova, M. (2015). Labor Market Laws and Intra-European Migration: The Role of the State in Shaping Destination Choices. European Journal of Population, 31(2), 127-153.

Pânzaru, C. (2013). The Determinants of International Migration. A Panel Data Analysis. Journal of Politics and Law, 6(1), 142-148. 
Pedace, R. (2013). Econometrics for Dummies. Hoboken: John Wiley \& Sons, Inc.

Pedersen, P. J., Plytlikova, M., \& Smith, N. (2008). Selection and network effectsMigration flows into OECD countries 1990-2000. European Economic Review, 52(7), 1160-1186.

Pejovich, S. (1992). A tulajdonjogok közgazdaságtana. Budapest: Közgazdasági és Jogi Könyvkiadó.

Piliavin, J. A., \& Charng, H.-W. (1990). Altruism: A Review of Recent Theory and Research. Annual Review of Sociology, 16, 27-65.

Polanyi, M. (1962). Personal Knowledge: Towards a Post-Critical Philosophy. New York: Harper \& Row.

Polgreen, L. A., \& Simpson, N. B. (2011). Happiness and International Migration. Journal of Happiness Studies, 12(5), 819-840.

Pollak, R. A. (1976). Interdependent Preferences. The American Economic Review, 66(3), 309-320.

Poot, J. (1996). Information, communication and networks in international migration systems. The annals of regional science, 30(1), 55-73.

Portes, A., \& Böröcz, J. (1989). Contemporary Immigration: Theoretical Perspectives on Its Determinants and Modes of Incorporation. The International Migration Review, 23(3), 606-630.

Portes, A., \& Sensenbrenner, J. (2007). Beágyazottság és bevándorlás: megjegyzések a gazdasági cselekvés társadalmi meghatározóiról. In Sik Endre, A migráció szociológiája (57-78. o.). Budapest: ELTE TáTK.

Ramanathat, R. (2003). Bevezetés az ökonometriába alkalmazásokkal. Budapest: Panem.

Rapoport, H. (1995). Coordination, Altruism and Under-Development. Kyklos, 48(3), 389-407.

Ravenstein, E. G. (1885). The Laws of Migration. Journal of the Statistical Society of London, 48(2), 167-235.

Ravenstein, E. G. (1889). The Laws of Migration. Journal of the Royal Statistical Society, 52(2), 241-305.

Riordan, M. H., \& Williamson, O. E. (1985). Asset Specificity and Economic Organization. International Journal of Industrial Organization, 3(4), 365-378.

Rossi, P. H. (1955). Why Families Move. Glencoe: The Free Press.

Roy, A. D. (1951). Some Thoughts on the Distribution of Earnings. Oxford Economic Papers, 3(2), 135-146. 
Ruget, V., \& Usmanalieva, B. (2008). Citizenship, migration and loyalty towards the state: a case study of the Kyrgyzstani migrants working in Russia and Kazakhstan. Central Asian Survey, 2, 129-141.

Sandell, S. H. (1977). Women and the Economics of Family Migration. The Review of Economics and Statistics, 59(4), 406-414.

Schewel, K. (2015). Understanding the Aspiration to Stay: A Case Study of Young Adults in Senegal. International Migration Institute Working Paper, No. 107., 1-37. Letöltve: https://www.imi-n.org/publications/wp-107-15/@@ download/file. (2019.06.20.)

Schultz, T. W. (1983). Beruházás az emberi tőkébe. Budapest: Közgazdasági és Jogi Könyvkiadó.

Sebők Marianna (2016). Munkaerö-piaci mobilitás Magyarországon. Budapest: Edge 2000 Kiadó.

Shaw, P. R. (1974). A Note on Cost-Return Calculations and Decisions to Migrate. Population Studies, 28(1), 167-169.

Sik Endre (2001, szerk.). A migráció szociológiája. Budapest: Szociális és Családügyi Minisztérium.

Sik Endre (2003). A migrációs potenciál kutatásának alapfogalmai. In Örkény Antal, Menni vagy maradni? Kedvezménytörvény és migrációs várakozások (15-18. o.). Budapest: MTA Kisebbségkutató Intézet.

Sik Endre (2012). A migrációs burok. In E. Sik, A migráció szociológiája 2. E-tankönyv (133-158. o.). Budapest: ELTE-TáTK.

Sik Endre (2018). Migrációs burok és migrációs potenciál. In Siskáné Szilasi Beáta \& Halász Levente, Boldogulni itthon vagy külföldön. Legújabb trendek a magyarországi kivándorlásban (106-127. o.). Miskolc: Miskolci Egyetem, Földrajz - Geoinformatika Intézet.

Sik Endre \& Örkény Antal (2003). A migrációs potenciál kialakulásának mechanizmusa. In Örkény Antal, Menni vagy maradni? Kedvezménytörvény és migrációs várakozások (188-200. o.). Budapest: MTA Kisebbségkutató Intézet.

Sik Endre \& Szeitl Blanka (2016a). Migrációs szándékok a mai Magyarországon. In Blaskó Zsuza \& Fazekas Károly, Munkaerőpiaci Tükör 2015 (54-58. o.). Budapest: MTA Közgazdaság- és Regionális Tudományi Kutatóközpont Közgazdaság-tudományi Intézet. 
Sik Endre \& Szeitl Blanka (2016b). Migráció a mai Magyarországról. Educatio, 25(4), 546-557.

Simon, H. A. (1959). Theories of Decision-Making in Economics and Behavioral Science. The American Economic Review, 49(3), 253-283.

Simon, H. A. (1972). Theories of bounded rationality. In C. B. McGuire, \& R. Radner, Decision and Organization (161-176. o.). Amsterdam: North-Holland Publishing Company.

Simon, H. A. (1982). Racionális döntés gazdasági szervezetekben. In H. A. Simon, Korlátozott racionalitás (21-58. o.). Budapest: Közgazdasági és Jogi Könyvkiadó.

Simon, H. A. (1987). Bounded Rationality. In Palgrave Macmillan, The New Palgrave Dictionary of Economics. London: Palgrave Macmillan. Letöltve: https://link.springer.com/referenceworkentry/10.1057\%2F978-1-349-951215_472-1 (2018.06.29.).

Simon, H. A. (1990). A Mechanism for Social Selection and Successful Altruism. Science, 250, 1665-1668.

Simon, H. A. (1993). Altruism and Economics. The American Economic Review, 83(2), 156-161.

Simon, H. A. (1997). Administrative Behavior. A Study of Decision-Making Processes in Administrative Organizations. Fourth Edition. New York: The Free Press.

Simon, H. A. (2008). Satisficing. In Palgrave Macmillan, The New Palgrave Dictionary of Economics. London: Palgrave Macmillan. Letöltve: https://link.springer.com/referenceworkentry/10.1057/978-1-349-95121-5_17672 (2018.06.29.).

Siposné Nándori Eszter, Dabasi-Halász Zsuzsanna \& Illyés Csaba (2017). „Hatás és ellenhatás” - A fiatalok európai mobilitásának hatása a gazdaságra és a munkaerőpiacra. Tér és Társadalom, 31(4), 9-26.

Sjaastad, L. A. (1962). The Costs and Returns of Human Migration. Journal of Political Economy, 70(5), 80-93.

Spaan, E., \& van Naerssen, T. (2017). Migration decision-making and migration industry in the Indonesia-Malaysia corridor. Journal of Ethnic and Migration Studies, 116.

Speare, A. J. (1971). A Cost-Benefit Model of Rural to Urban Migration in Taiwan. Population Studies, 25(1), 117-130. 
Speare, A. J. (1974). Residential satisfaction as an intervening variable in residential mobility. Demography, 11(2), 173-188.

Sprenger, E. (2013). The Determinants of International Migration in the European Union: An Empirical Analysis. IOS Working Papers, 325, Letöltve: http://www.dokumente.ios-regensburg.de/publikationen/wp/wp_ios_325.pdf (2014.01.23.).

Stahl, C. W. (1995). Theories of International Labor Migration: An Overview. Asian and Pacific Migration Journal, 4(2-3), 211-232.

Stark, O. (1991). The Migration of Labor. Cambridge: Basil Blackwell.

Stark, O., \& Bloom, D. E. (1985). The New Economics of Labor Migration. American Economic Review, 75(2), 173-178.

Stark, O., \& Taylor, E. J. (1989). Relative Deprivation and International Migration. Demography, 26(1), 1-14.

Stark, O., \& Taylor, E. J. (1991). Migration Incentives, Migration Types: The Role of Relative Deprivation. The Economic Journal, 101(408), 1163-1178.

Stark, O., Micevska, M., \& Mycielski, J. (2009). Relative poverty as a determinant of migration: Evidence from Poland. Economics Letters, 103(3), 119-122.

Stigler, G. J. (1989). Az információszerzés közgazdaságtana. In G. J. Stigler, Piac és állami szabályozás (232-253. o.). Budapest: Közgazdasági és Jogi Könyvkiadó.

Stiglitz, J. E. (1991). The Invisible Hand and Modern Welfare Economics. Working Paper No. 3641 .

Stone, D. (1997). Policy Paradox. The Art of Political Decision Making. New York: W. W. Norton \& Co.

Szentes Tamás (2019). A nemzetközi migráció ügye a szélsőséges nézetek tükrében. Magyar Tudomány, 180(1), 10-27.

Tálas Péter (2019). A migráció mint biztonságpolitikai probléma. Magyar Tudomány, 180(1), 67-78.

Tétényi, A., Barczikay, T., \& Szent-Iványi, B. (2018). Refugees, not Economic Migrants - Why do Asylum-Seekers Register in Hungary? International Migration(Special Issue), 1-18.

Thaler, R. H. (1999). Mental accounting matters. Journal of Behavioral Decision Making, 12(3), 183-206.

Thaler, R. H. (2016). Rendbontók: A viselkedési közgazdaságtan térnyerése. Budapest: HVG Zrt. 
Tiebout, C. M. (1956). A pure theory of local expenditures. Journal of political economy, 64(5), 416-424.

Tirole, J. (1986). Procurement and Renegotiation. Journal of Political Economy, 94(2), 235-259.

Tobler, W. (1995). Migration: Ravenstein, Thorntwaite, and Beyond. Urban Geography, 16(4), 327-343.

Todaro, M. P. (1969). A Model of Labor Migration and Urban Unemployment in Less Developed Countries. The American Economic Review, 59(1), 138-148.

Todaro, M. P., \& Maruszko, L. (1987). Illegal Migration and US Immigration Reform: A Conceptual Framework. Population and Development Review, 13(1), 101-114.

Tóth László (2018). Korlátozott racionalitás. Kézirat (Intézményi közgazdaságtan tanköny fejezete, 2018.02. 04. szerinti változat).

Tóth Pál Péter (2012, szerk.). A migrációs statisztika fejlesztésének lehetőségei. Megvalósithatósági tanulmány. Budapest: Európai Integrációs Alap.

Tőkés László (2017). Bevezetés a Stata használatába. Budapest: Akadémiai Kiadó.

Tullock, G. (2005). The Theory of Public Choice. In G. Tullock, A. Seldon, \& G. L. Brady, Government Failure. A Primer in Public Choice (3-79. o.). Washington: Cato Institute.

Tyler, T. R. (2001). Public Trust and Confi dence in Legal Authorities: What Do Majority and Minority Group Members Want from the Law and Legal Institutions? Behaviroal Sciences and the Law, 19(2), 215-235.

van Dalen, H. P., \& Henkens, K. (2013). Explaining emigration intentions and behaviour in the Netherlands, 2005-10. Population Studies, 67(2), 225-241.

Van Est, J. (1981). An Inter-Regional Migration Model: A Disaggregate Approach. Paper presented at the 20th European Congress of the Regional Science Association, Letöltve: https://repository.tudelft.nl/islandora/object/uuid:c5d9cd01-c77e-4032882f-0070ba880ce8/datastream/OBJ (2017.08.03.).

Van Hear, N., Bakewell, O., \& Long, K. (2018). Push-pull plus: reconsidering the drivers of migration. Journal of Ethnic and Migration Studies, 44(6), 927-944.

Waldorf, B. S., \& Esparza, A. (1988). Labor migration to Western Europe: a commentary on O'Loughlin, 1986. Environment and Planning A, 20(8), 1121-1124.

Walsh, B. M. (1974). Expectations, information, and human migration: specifying an econometric model of Irish migration to Britain. Journal of Regional Science, 14(1), 107-120. 
Wang, Z., de Graaf, T., \& Nijkamp, P. (2018). Barriers of Culture, Networks, and Language in International Migration: A Review. Region, 5(1), 73-89.

Williamson, O. E. (1985). The Economic Institutions of Capitalism. Firms, Market, Relational Contracting. New York: Free Press.

Williamson, O. E. (1991). Comparative Economic Organization: The Analysis of Discrete Structural Alternatives. Administrative Science Quarterly, 36(2), 269296.

Williamson, O. E. (2000). The New Institutional Economics: Taking Stock, Looking Ahead. Journal of Economic Literature, 38(3), 595-613.

Williamson, O. E. (2007). A tranzakciós költségek gazdaságtana: a szerződéses kapcsolatok irányítása. Kormányzás, Közpénzügyek, Szabályozás, 2(2), 235-255.

Williamson, O. E. (2010). Transaction Cost Economics: The Natural Progression. The American Economic Review, 100(3), 673-690.

Wolpert, J. (1966). Migration as an Adjustment to Environmental Stress. Journal of Social Issues, 22(4), 92-102.

Wooldridge, J. W. (2016). Introductory Econometrics. A Modern Approach. Sixth Edition. Boston: Cengage Learning.

Zaiceva, A., \& Zimmermann, K. F. (2008a). Scale, diversity, and determinants of labour migration in Europe. Oxford Review of Economic Policy, 24(3), 428-452.

Zaiceva, A., \& Zimmermann, K. F. (2008b). Scale, Diversity, and Determinants of Labour Migration in Europe. IZA Discussion Paper No. 3595, Letöltve: https://www.econstor.eu/bitstream/10419/35035/1/573772967.pdf (2017.11.03.).

Zimmermann, K. F. (1994). European migration: Push and pull. The World Bank Economic Review, 8(suppl 1), 313-342. 


\title{
MELLÉKLETEK
}

\author{
3.1. melléklet
}

\section{A 2004 és 2016 közötti Eurobarometerek migrációs potenciálra vonatkozó kérdései}

Felmérés

64.1 (2005)

$67.1(2007)$

$70.1(2008)$

$72.5(2009)$

73.3 (2010)

$75.1(2011)$

$79.2(2013)$

Flash Eurobarometer 395

(European Youth 2014)

85.1OVR (2016)

(16-30 év közöttiek)

Migrációs potenciálra vonatkozó kérdés

Mennyire valószínű, hogy a következő öt évben Ön elköltözik?

- az Európai Unió egy másik tagországába

- az Európai Unión kívül egy másik országba

Szándékozik egyáltalán elköltözni a következö öt évben?

- Másik, EU-n belüli országba költözni

- Másik, EU-n kívüli országba költözni

Szándékozik egyáltalán elköltözni a következö öt évben?

- Másik, EU-n belüli országba költözni

- Másik, EU-n kívüli országba költözni

Ön elképzelhetőnek tartja azt, hogy Magyarországon kívüli országba megy dolgozni valamikor a jövőben?

Mit gondol, mennyire valószínü, hogy az elkövetkező tíz évben egy másik országba költözik?

Fontolóra venné-e azt, hogy egy másik EU tagállamban dolgozzon, nem Magyarországon?

Megfontolná, hogy Magyarországon kívül egy másik EU tagállamban dolgozzon (újra) a következő 10 évben?

Ön akar tanulni, képzést kapni vagy dolgozni más EU országban, mint Magyarország?

Ön akar tanulni, képzést kapni vagy dolgozni más EU országban, mint Magyarország?

Megjegyzés: mint azt ellenőriztük, a kérdések megfogalmazásának változatosságáért nem a kérdőívek magyar fordítása volt a felelős. Az angol nyelvü kérdésekben ugyanilyen változatossággal találkoztunk.

Forrás: European Commission (2012a; 2012b; 2012c; 2012d), European Commission \& European Parliament, Brussels (2013; 2016), European Parliament \& DG Communication, Brussels (2014) 
A 2008-as és 2010-es Eurobarometer felmérésben résztvevők országonkénti száma

\begin{tabular}{lrr}
\multicolumn{1}{c}{ Ország } & \multicolumn{2}{c}{ Válaszadók száma } \\
& 2008-as felmérés & 2010-es felmérés \\
\hline Ausztria & 1003 & 1000 \\
Belgium & 1002 & 1030 \\
Bulgária & 1006 & 1001 \\
Ciprus & 503 & 507 \\
Csehország & 1026 & 1000 \\
Dánia & 1029 & 1026 \\
Észak-Írország & 301 & 303 \\
Észtország & 1000 & 1000 \\
Finnország & 1004 & 1001 \\
Franciaország & 1027 & 1008 \\
Görögország & 1000 & 1000 \\
Hollandia & 1041 & 1000 \\
Írország & 1000 & 1000 \\
Lengyelország & 1000 & 1000 \\
Lettország & 1002 & 1005 \\
Litvánia & 1011 & 1016 \\
Luxembourg & 500 & 520 \\
Magyarország & 1002 & 1030 \\
Málta & 500 & 500 \\
Nagy-Britannia & 1007 & 1026 \\
Németország & 1526 & 1481 \\
Olaszország & 1061 & 1038 \\
Portugália & 1000 & 1024 \\
Románia & 1053 & 1022 \\
Spanyolország & 1000 & 1004 \\
Svédország & 1002 & 1015 \\
Szlovákia & 1006 & 1030 \\
Szlovénia & 1006 & 1015 \\
San Com & & \\
\hline & &
\end{tabular}

Forrás: European Commission (2012c, 2012d) 


\section{1. melléklet}

A potenciális migránsok aránya az EU-tagállamokban (2008)

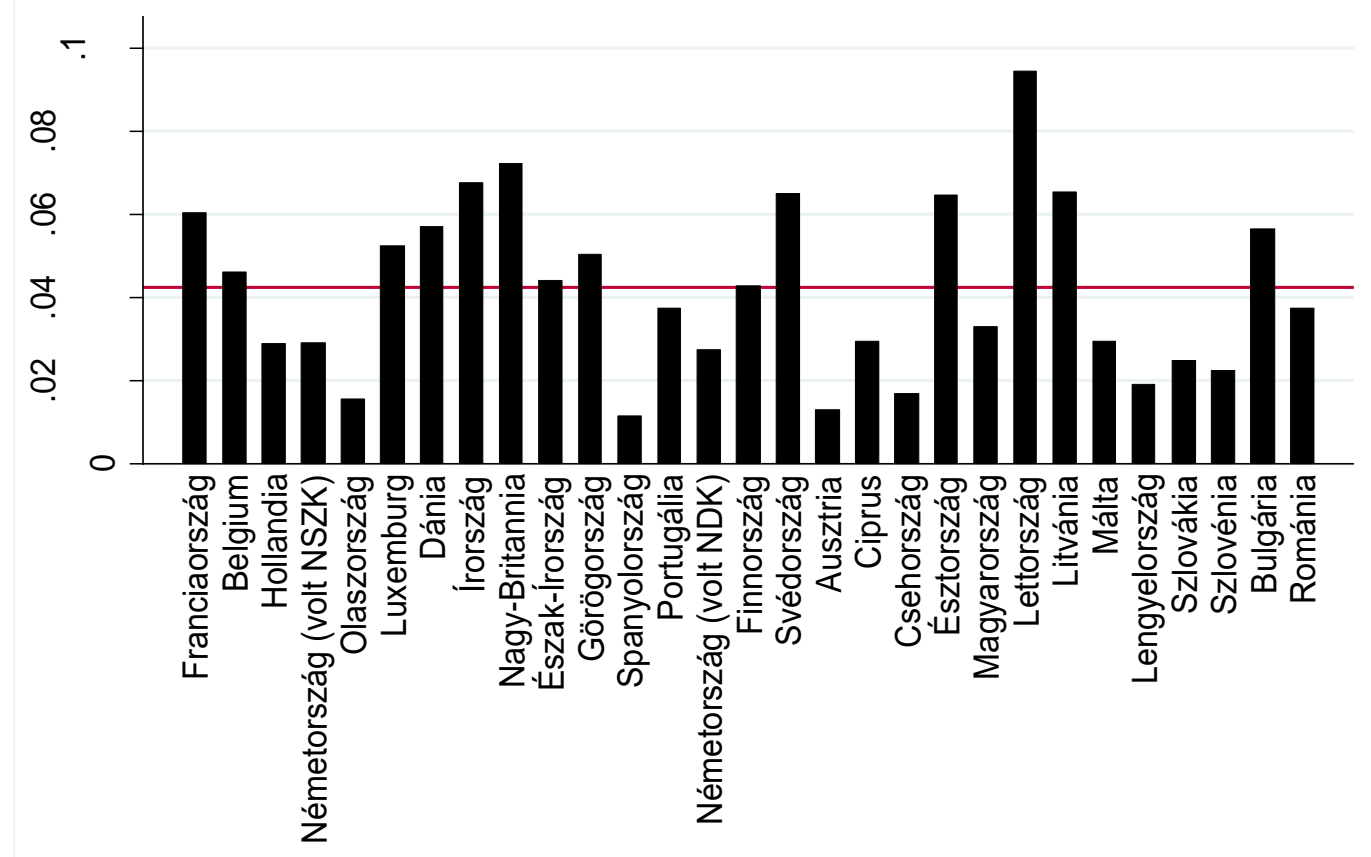

Forrás: European Commission (2012c)

\section{2. melléklet}

A tisztított migrációs potenciállal rendelkezők aránya az EU-tagállamokban (2008)

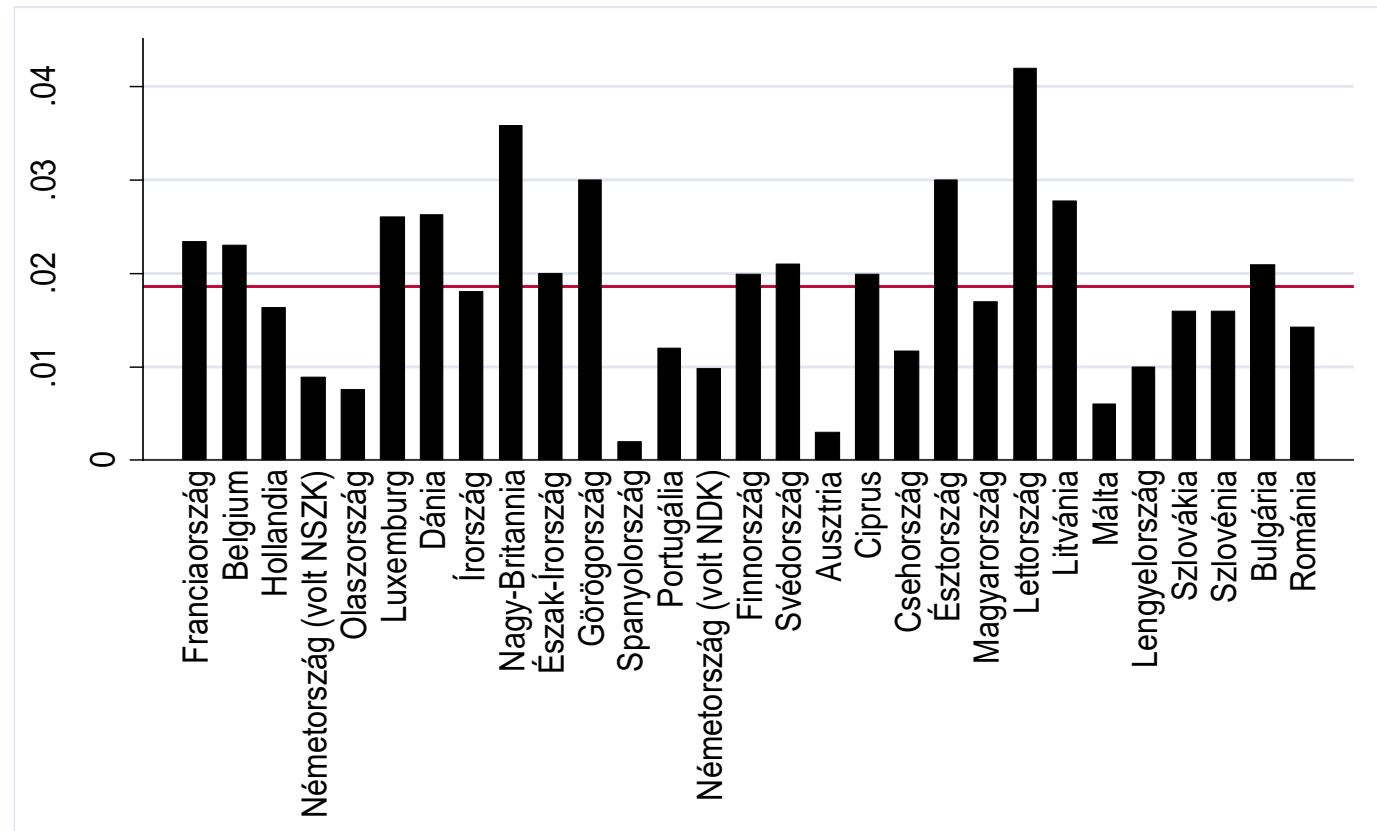

Forrás: European Commission (2012c) 


\section{3. melléklet}

A potenciális migránsok aránya az EU-tagállamokban (2010)

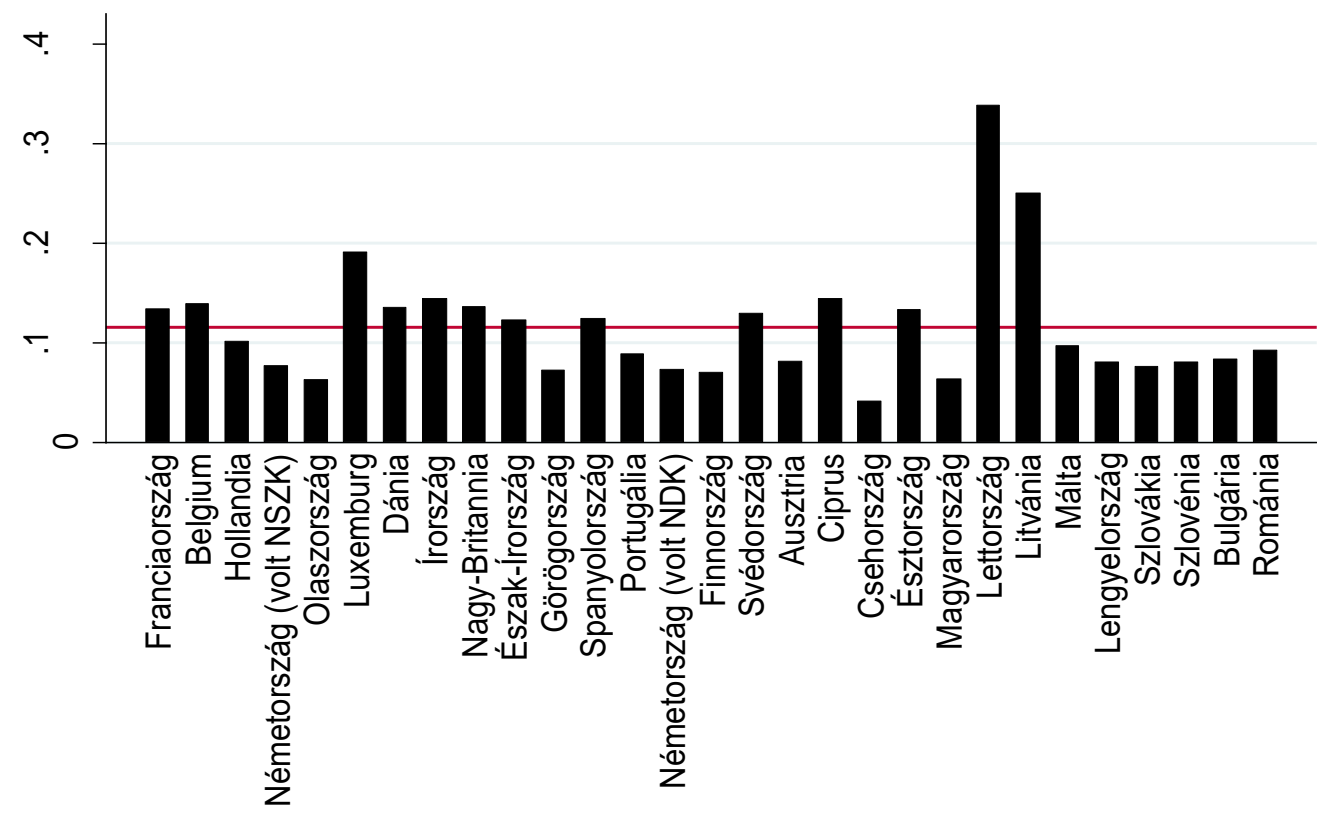

Forrás: European Commission (2012d)

\section{4. melléklet}

A tisztított migrációs potenciállal rendelkezők aránya az EU-tagállamokban (2008)

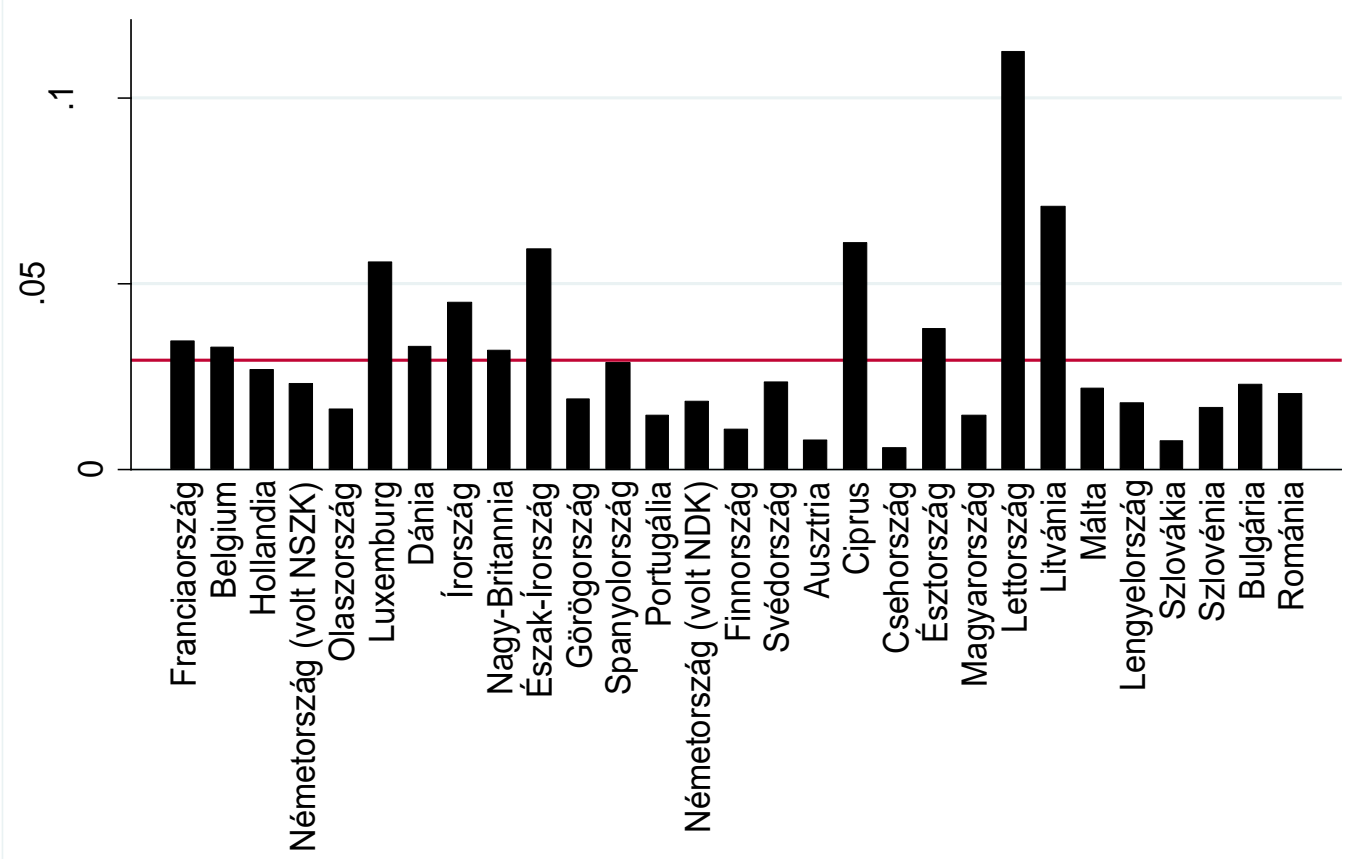

Forrás: European Commission (2012d) 


\section{5. melléklet}

A potenciális migránsok aránya az EU-tagállamokban a migráció vélt valószínűsége szerinti bontásban (2010)

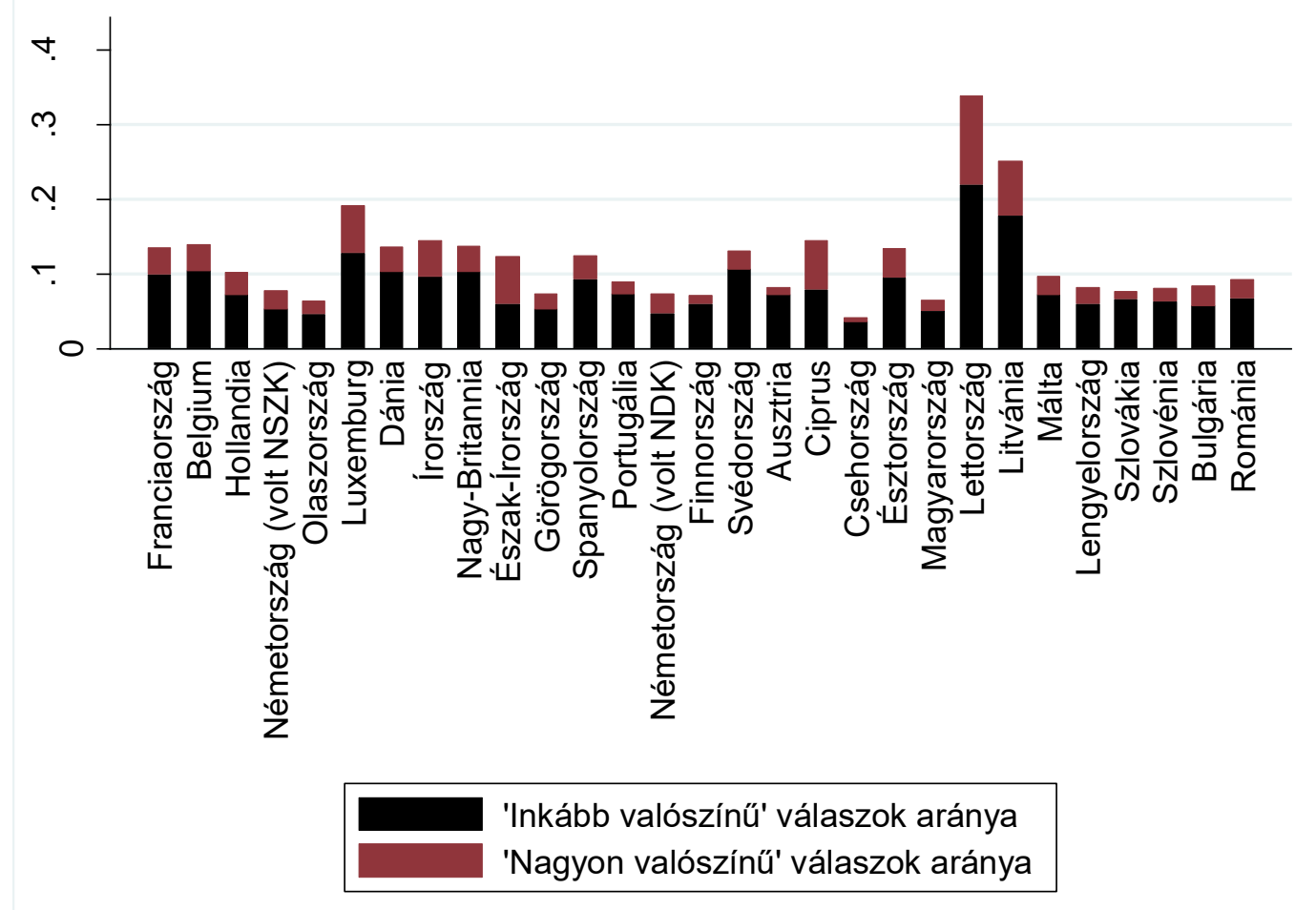

Forrás: European Commission (2012d) 


\section{1. melléklet}

\section{Likelihood ratio tesztek eredményei az első vizsgálatban}

\begin{tabular}{|c|c|c|c|c|c|}
\hline $\begin{array}{l}\begin{array}{l}\text { Korlátozott } \\
\text { modell }\end{array} \\
\text { Teljes modell }\end{array}$ & $\begin{array}{l}\text { (I) specifikáció } \\
\text { (II) specifikáció }\end{array}$ & $\begin{array}{l}\text { (I) specifikáció } \\
\text { (II.1) specifikáció }\end{array}$ & $\begin{array}{l}\text { (II.1) specifikáció } \\
\text { (II.1.1) specifikáció }\end{array}$ & $\begin{array}{l}\text { (II.1) specifikáció } \\
\text { (II.1.2) specifikáció }\end{array}$ & $\begin{array}{l}\text { (II.1) specifikáció } \\
\text { (II.1.3) } \\
\text { specifikáció }\end{array}$ \\
\hline LR chi2(2) & 270,13 & 963,10 & 171,95 & 22,53 & 58,18 \\
\hline Prob > chi 2 & 0,0000 & 0,0000 & 0,0000 & 0,0000 & 0,0000 \\
\hline
\end{tabular}

Forrás: saját számitás European Commission (2012c) alapján

\section{2. melléklet}

A likelihood ratio khí négyzet próbák (G teszt) eredményei az első vizsgálatban

\begin{tabular}{lrrrrr} 
& \multicolumn{1}{c}{ (I) } & \multicolumn{1}{c}{ (II) } & \multicolumn{1}{c}{ (I.1) } & \multicolumn{1}{c}{ (I.2) } & \multicolumn{1}{c}{ (II.1) } \\
\hline Log-Lik Intercept Only: & $-4208,589$ & $-4041,757$ & $-4208,589$ & $-4208,589$ & $-3608,424$ \\
Log-Lik Full Model: & $-3322,636$ & $-3187,572$ & $-3330,555$ & $-3330,815$ & $-2841,087$ \\
D(24162): & 6645,272 & 6375,144 & 6661,111 & 6661,629 & 5682,174 \\
LR(20): & 1771,906 & 1708,369 & 1756,068 & 1755,549 & 1534,674 \\
Prob > LR: & 0,000 & 0,000 & 0,000 & 0,000 & 0,000
\end{tabular}

\begin{tabular}{|c|c|c|c|c|c|c|}
\hline & $\begin{array}{l}\text { (II.1) } \\
\text { régi tagállamok } \\
\text { almintája }\end{array}$ & $\begin{array}{c}\text { (II.1) } \\
\text { új } \\
\text { tagállamok } \\
\text { almintája }\end{array}$ & $\begin{array}{c}\text { (II.1) } \\
\text { tisztított } \\
\text { migrációs } \\
\text { potenciálon }\end{array}$ & (II.1.1) & (II.1.2) & (II.1.3) \\
\hline Log-Lik Intercept Only: & $-2140,646$ & $-1467,656$ & $-1994,315$ & $-3608,424$ & $-3608,424$ & -3596.384 \\
\hline Log-Lik Full Model: & $-1721,468$ & $-1078,406$ & $-1637,391$ & $-2755,112$ & $-2829,822$ & -2811.997 \\
\hline $\mathrm{D}(24162):$ & 3442,936 & 2156,811 & 3274,782 & 5510,224 & 5659,645 & 5623.994 \\
\hline $\operatorname{LR}(20)$ : & 838,357 & 778,502 & 713,848 & 1706,623 & 1557,202 & 1568.774 \\
\hline Prob > LR: & 0,000 & 0,000 & 0,000 & 0,000 & 0,000 & 0.000 \\
\hline
\end{tabular}

Forrás: saját számitás European Commission (2012c) alapján 


\section{3. melléklet}

\section{A Hosmer-Lemeshow tesztek eredményei az első vizsgálatban}

\begin{tabular}{lrrrrr} 
& \multicolumn{1}{c}{ (I) } & \multicolumn{1}{c}{ (II) } & \multicolumn{1}{c}{ (I.1) } & \multicolumn{1}{c}{ (I.2) } & \multicolumn{1}{c}{ (II.1) } \\
\hline Hosmer-Lemeshow chi2(2) & 1,21 & 1,17 & 0,63 & 2,26 & 1,45 \\
Prob $>$ chi2 & 0,5454 & 0,5578 & 0,7305 & 0,3227 & 0,4849
\end{tabular}

$\begin{array}{rrrrr}\begin{array}{c}\text { (II.1) } \\ \text { régi } \\ \begin{array}{c}\text { tagállamok } \\ \text { almintája }\end{array}\end{array} & \begin{array}{c}\text { (II.1) } \\ \text { tagállamok } \\ \text { almintája }\end{array} & \begin{array}{c}\text { (II.1) } \\ \text { tisztított } \\ \text { migrációs } \\ \text { potenciálon }\end{array} & \text { (II.1.1) } & \text { (II.1.2) } \\ 1,01 & 3,31 & 1,10 & 11,55 & 1,46 \\ 0,6034 & 0,1911 & 0,5757 & 0,0031 & 0,4815\end{array}$

Forrás: saját számítás European Commission (2012c) alapján

\section{4. melléklet}

\section{A VIF mutatók értékei az első vizsgálat specifikációiban ${ }^{103}$}

\begin{tabular}{|c|c|c|c|c|c|c|c|c|}
\hline \multicolumn{3}{|c|}{ (I) } & \multicolumn{3}{|c|}{ (II) } & \multicolumn{3}{|c|}{ (I.1) } \\
\hline Variable & VIF & $1 / \mathrm{VIF}$ & Variable & VIF & $1 / \mathrm{VIF}$ & Variable & VIF & $1 / \mathrm{VIF}$ \\
\hline kor & 18.03 & 0.055451 & kor & 18.29 & 0.054676 & kor & 18.00 & 0.055545 \\
\hline iskola & 12.55 & 0.079664 & iskola & 12.87 & 0.077729 & iskola & 12.49 & 0.080055 \\
\hline nyelv1 & 5.96 & 0.167712 & nyelv1 & 6.01 & 0.166478 & nyelv1 & 5.60 & 0.178595 \\
\hline ingatlan_ & 4.66 & 0.214751 & ingatlan_ & 4.69 & 0.213018 & ingatlan_ & 4.66 & 0.214802 \\
\hline nyugdijas & 4.24 & 0.236110 & nyugdijas & 4.16 & 0.240462 & nyugdijas & 4.23 & 0.236246 \\
\hline internet & 2.79 & 0.358189 & internet & 2.86 & 0.349146 & internet & 2.78 & 0.359732 \\
\hline falu & 2.39 & 0.418984 & falu & 2.38 & 0.419457 & falu & 2.39 & 0.419213 \\
\hline kisvaros & 2.32 & 0.431883 & kisvaros & 2.32 & 0.430491 & kisvaros & 2.31 & 0.432035 \\
\hline nyelv2 & 2.03 & 0.491764 & biz_jog & 2.12 & 0.471376 & nem & 1.98 & 0.506324 \\
\hline nem & 1.98 & 0.506238 & nyelv2 & 2.03 & 0.492016 & foglalkoz $\sim \mathrm{kg}$ & 1.87 & 0.533700 \\
\hline foglalkoz kg & 1.88 & 0.532105 & nem & 2.00 & 0.500746 & csalad3 & 1.83 & 0.545112 \\
\hline csalad3 & 1.84 & 0.544468 & foglalkoz $\sim \mathrm{kg}$ & 1.87 & 0.534268 & munkanelkuli & 1.69 & 0.590626 \\
\hline munkanelkuli & 1.69 & 0.590451 & csalad3 & 1.85 & 0.540472 & tanulo & 1.64 & 0.609323 \\
\hline tanulo & 1.64 & 0.608973 & munkanelkuli & 1.67 & 0.597838 & csalad5 & 1.52 & 0.657178 \\
\hline csalad5 & 1.52 & 0.656972 & tanulo & 1.64 & 0.609329 & gyerek & 1.49 & 0.669634 \\
\hline gyerek & 1.49 & 0.669633 & gyerek & 1.51 & 0.662599 & onfoglalko o & 1.33 & 0.749075 \\
\hline onfoglalko o & 1.34 & 0.748949 & csalad5 & 1.50 & 0.665494 & csalad2 & 1.24 & 0.807825 \\
\hline csalad2 & 1.24 & 0.807296 & onfoglalko o & 1.34 & 0.748710 & csalad4 & 1.18 & 0.846306 \\
\hline csalad4 & 1.18 & 0.846306 & int_inf & 1.28 & 0.784259 & halo_tap & 1.08 & 0.922228 \\
\hline halo_tap & 1.09 & 0.916885 & csalad2 & 1.24 & 0.804368 & & & \\
\hline & & & csalad4 & 1.19 & 0.843232 & Mean VIF & 3.65 & \\
\hline Mean VIF & 3.59 & & halo_tap & 1.09 & 0.913423 & & & \\
\hline & & & Mean VIF & 3.45 & & & & \\
\hline
\end{tabular}

\footnotetext{
${ }^{103}$ A táblázatban szereplő $01,02, \ldots, o 29$ ország dummyk rendre a következő országokra utalnak: Belgium, Hollandia, Németország (volt NSZK), Olaszország, Luxemburg, Dánia, Írország, Nagy-Britannia, ÉszakÍrország, Görögország, Spanyolország, Portugália, Németország (volt NDK), Finnország, Svédország, Ausztria, Ciprus, Csehország, Észtország, Magyarország, Lettország, Litvánia, Málta, Lengyelország, Szlovákia, Szlovénia, Bulgária, Románia.
} 
(I.2)

\begin{tabular}{lll} 
Variable & VIF & $1 / \mathrm{VIF}$ \\
\hline & & \\
kor & 17.30 & 0.057799 \\
iskola & 12.06 & 0.082910 \\
ingatlan_ & 4.65 & 0.215064 \\
nyugdijas & 4.23 & 0.236378 \\
internet & 2.77 & 0.360929 \\
falu & 2.38 & 0.419773 \\
kisvaros & 2.31 & 0.432629 \\
nem & 1.98 & 0.506278 \\
nyelv2 & 1.91 & 0.523674 \\
foglalkoz kg & 1.87 & 0.534183 \\
csalad3 & 1.82 & 0.549383 \\
munkanelkuli & 1.69 & 0.592435 \\
tanulo & 1.63 & 0.612255 \\
csalad5 & 1.52 & 0.657001 \\
gyerek & 1.48 & 0.674730 \\
onfoglalko 0 & 1.33 & 0.749440 \\
csalad2 & 1.23 & 0.813205 \\
csalad4 & 1.18 & 0.846414 \\
halo_tap & 1.09 & 0.918629
\end{tabular}

Mean VIF 3.39
(II.1)

\begin{tabular}{lll} 
Variable & VIF & $1 / \mathrm{VIF}$ \\
\hline kor & 18.50 & 0.054064 \\
iskola & 13.13 & 0.076135 \\
nyelv1 & 5.96 & 0.167905 \\
ingatlan_ & 4.76 & 0.210201 \\
nyugdijas & 4.13 & 0.241849 \\
internet & 2.89 & 0.346016 \\
biz_ALT & 2.39 & 0.417676 \\
falu & 2.39 & 0.418298 \\
kisvaros & 2.35 & 0.426011 \\
nem & 2.03 & 0.492375 \\
nyelv2 & 2.03 & 0.492661 \\
foglalkoz kg & 1.86 & 0.536456 \\
csalad3 & 1.85 & 0.541774 \\
munkanelkuli & 1.64 & 0.608391 \\
tanulo & 1.63 & 0.613183 \\
gyerek & 1.52 & 0.658034 \\
csalad5 & 1.48 & 0.673473 \\
onfoglalko o & 1.35 & 0.743141 \\
int_inf & 1.28 & 0.782381 \\
csalad2 & 1.24 & 0.804462 \\
csalad4 & 1.19 & 0.843422 \\
halo_tap & 1.09 & 0.915511 \\
& & \\
Mean VIF & 3.49 & \\
& &
\end{tabular}

(II.1.2)

\begin{tabular}{lll} 
Variable & VIF & 1/VIF \\
\hline kor & 18.59 & 0.053782 \\
iskola & 13.31 & 0.075108 \\
nyelv1 & 5.97 & 0.167502 \\
ingatlan_ & 4.77 & 0.209559 \\
nyugdijas & 4.14 & 0.241817 \\
internet & 2.90 & 0.345277 \\
biz_ALT & 2.40 & 0.417346 \\
falu & 2.39 & 0.418084 \\
kisvaros & 2.35 & 0.425663 \\
nyelv2 & 2.07 & 0.483974 \\
lelki & 2.05 & 0.488678 \\
nem & 2.03 & 0.491816 \\
foglalkoz kg & 1.86 & 0.536356 \\
csalad3 & 1.85 & 0.541255 \\
munkanelkuli & 1.64 & 0.608087 \\
tanulo & 1.63 & 0.612156 \\
gyerek & 1.52 & 0.657515 \\
csalad5 & 1.49 & 0.673129 \\
onfoglalko o & 1.35 & 0.743081 \\
int_inf & 1.29 & 0.772968 \\
csalad2 & 1.24 & 0.803901 \\
csalad4 & 1.19 & 0.843412 \\
halo_tap & 1.09 & 0.914436 \\
& &
\end{tabular}

(II.1.1)

Variable VIF 1/VIF

$\begin{array}{lll}\text { kor } & 22.05 & 0.045359\end{array}$

iskola $\quad 15.58 \quad 0.064185$

$\begin{array}{lll}\text { nyelv1 } & 6.24 & 0.160323\end{array}$

ingatlan_ $\quad 5.26 \quad 0.189965$

nyugdijas $\quad 4.22 \quad 0.237008$

$\begin{array}{lll}\text { internet } & 3.21 & 0.311161\end{array}$

biz_ALT $\quad 2.79 \quad 0.357943$

kisvaros $\quad 2.49 \quad 0.401076$

$\begin{array}{lll}\text { falu } & 2.48 & 0.403605\end{array}$

$\begin{array}{lll}\text { nyelv2 } & 2.09 & 0.478540\end{array}$

nem $\quad 2.05 \quad 0.487850$

$\begin{array}{lll}07 & 2.04 & 0.490380\end{array}$

$\begin{array}{lll}03 & 1.96 & 0.511218\end{array}$

$\begin{array}{lll}015 & 1.95 & 0.512852\end{array}$

$\begin{array}{lll}016 & 1.95 & 0.513439\end{array}$

foglalkoz kg $\quad 1.95 \quad 0.513839$

$\begin{array}{lll}\text { csalad3 } & 1.94 & 0.514573\end{array}$

$\begin{array}{lll}\mathrm{o} 11 & 1.88 & 0.531359\end{array}$

$\begin{array}{lll}\text { o2 } & 1.86 & 0.536367\end{array}$

$\begin{array}{lll}\text { o20 } & 1.76 & 0.568015\end{array}$

munkanelkuli $\quad 1.75 \quad 0.569918$

$\begin{array}{lll}\mathrm{o} 4 & 1.72 & 0.580559\end{array}$

$\begin{array}{lll}019 & 1.72 & 0.580601\end{array}$

$\begin{array}{lll}027 & 1.72 & 0.582407\end{array}$

$\begin{array}{lll}026 & 1.71 & 0.583337\end{array}$

tanulo $\quad 1.71 \quad 0.585179$

$\begin{array}{lll}09 & 1.68 & 0.594416\end{array}$

$\begin{array}{lll}08 & 1.67 & 0.599901\end{array}$

$\begin{array}{lll}012 & 1.66 & 0.601396\end{array}$

$\begin{array}{lll}\text { o22 } & 1.66 & 0.601786\end{array}$

$\begin{array}{lll}028 & 1.63 & 0.613370\end{array}$

$\begin{array}{lll}05 & 1.63 & 0.614235\end{array}$

$\begin{array}{lll}\text { o21 } & 1.61 & 0.621544\end{array}$

$\begin{array}{lll}\mathrm{o} 25 & 1.61 & 0.622415\end{array}$

$\begin{array}{lll}023 & 1.60 & 0.623917\end{array}$

$\begin{array}{lll}017 & 1.60 & 0.625247\end{array}$

$\begin{array}{lll}013 & 1.58 & 0.631139\end{array}$

$\begin{array}{lll}\mathrm{o} 29 & 1.58 & 0.633675\end{array}$

$\begin{array}{lll}\text { gyerek } & 1.56 & 0.639857\end{array}$

$\begin{array}{lll}\text { csalad5 } & 1.49 & 0.668969\end{array}$

$\begin{array}{lll}\text { o18 } & 1.38 & 0.725457\end{array}$

onfoglalko o $\quad 1.38 \quad 0.726571$

$\begin{array}{lll}\text { o14 } & 1.35 & 0.741064\end{array}$

$\begin{array}{lll}\text { o6 } & 1.35 & 0.742034\end{array}$

$\begin{array}{lll}\text { o24 } & 1.31 & 0.765697\end{array}$

int_inf $\quad 1.30 \quad 0.768560$

$\begin{array}{lll}\text { csalad2 } & 1.27 & 0.787149\end{array}$

$\begin{array}{lll}\text { csalad4 } & 1.21 & 0.824801\end{array}$

$\begin{array}{lll}\text { o10 } & 1.20 & 0.830701\end{array}$

halo_tap $\quad 1.11 \quad 0.901089$ 
(II.1) Régi tagállamok

\section{kor}

Variable

iskola

nyelv1

ingatlan_

nyugdijas

internet

biz_ALT

kisvaros

falu

nem

nyelv2

foglalkoz kg

csalad3

munkanelkuli 1.68

tanulo $\quad 1.53$

gyerek $\quad 1.52$

csalad5 $\quad 1.45$

onfoglalko o 1.36

int_inf

csalad2

csalad4

halo_tap

Mean VIF $\quad 3.44$
(II.1) Új tagállamok

\begin{tabular}{lll} 
Variable & VIF & 1/VIF \\
\hline & & \\
kor & 21.26 & 0.047034 \\
iskola & 18.42 & 0.054279 \\
ingatlan_ & 6.26 & 0.159846 \\
nyelv1 & 5.30 & 0.188587 \\
nyugdijas & 4.52 & 0.221011 \\
falu & 2.52 & 0.396189 \\
internet & 2.44 & 0.409354 \\
kisvaros & 2.37 & 0.422243 \\
csalad3 & 1.99 & 0.501851 \\
foglalkoz kg & 1.99 & 0.503103 \\
nyelv2 & 1.94 & 0.515085 \\
biz_ALT & 1.94 & 0.515618 \\
nem & 1.92 & 0.522076 \\
tanulo & 1.85 & 0.540427 \\
munkanelkuli & 1.62 & 0.618111 \\
csalad5 & 1.55 & 0.646549 \\
gyerek & 1.53 & 0.652578 \\
onfoglalko o & 1.33 & 0.751993 \\
int_inf & 1.26 & 0.796605 \\
csalad2 & 1.24 & 0.806802 \\
csalad4 & 1.17 & 0.852571 \\
halo_tap & 1.06 & 0.941631 \\
& & \\
Mean VIF & 3.89 & \\
& &
\end{tabular}

(II.1) Tisztított migrációs potenciál

\begin{tabular}{lll} 
Variable & VIF $1 / \mathrm{VIF}$ \\
\hline
\end{tabular}

kor

$18.29 \quad 0.054665$

iskola $\quad 13.23 \quad 0.075584$

nyelv1 $\quad 6.00 \quad 0.166568$

ingatlan_ $\quad 4.65 \quad 0.215283$

nyugdijas $\quad 4.05 \quad 0.246869$

internet $\quad 2.91 \quad 0.343543$

biz_ALT $\quad 2.38 \quad 0.420695$

$\begin{array}{lll}\text { falu } & 2.36 & 0.423111\end{array}$

$\begin{array}{lll}\text { kisvaros } & 2.33 & 0.429509\end{array}$

nyelv2 $\quad 2.05 \quad 0.488718$

$\begin{array}{lll}\text { nem } & 2.03 & 0.492404\end{array}$

$\begin{array}{lll}\text { csalad3 } & 1.90 \quad 0.525807\end{array}$

foglalkoz $\sim \mathrm{kg} \quad 1.86 \quad 0.537851$

tanulo $\quad 1.66 \quad 0.601670$

munkanelkuli $1.64 \quad 0.610543$

$\begin{array}{lll}\text { gyerek } & 1.52 & 0.660007\end{array}$

csalad5 $\quad 1.48 \quad 0.676573$

onfoglalko o $\quad 1.34 \quad 0.745690$

int_inf $\quad 1.28 \quad 0.783379$

csalad2 $\quad 1.25 \quad 0.800322$

csalad4 $\quad 1.18 \quad 0.843893$

halo_tap $\quad 1.10 \quad 0.911271$

Mean VIF $\quad 3.48$

Forrás: saját számitás European Commission (2012c) alapján

\section{5. melléklet}

\section{A link teszt eredményei az első vizsgálatban}

\begin{tabular}{|c|c|c|c|c|c|c|c|c|c|c|}
\hline & (I) & (II) & (I.1) & (I.2) & (II.1) & $\begin{array}{l}\text { (II.1) } \\
\text { régi } \\
\text { tagállamok } \\
\text { almintája } \\
\end{array}$ & $\begin{array}{c}\text { (II.1) } \\
\text { új } \\
\text { tagállamok } \\
\text { almintája } \\
\end{array}$ & $\begin{array}{c}\text { (II.1) } \\
\text { tisztított } \\
\text { migrációs } \\
\text { potenciálon }\end{array}$ & (II.1.1) & (II.1.2) \\
\hline \multirow[t]{3}{*}{ _hat } & .8307704 & .8238732 & .8412481 & .8201894 & .8577548 & .8906688 & .9316717 & .7675827 & .8728828 & .8346433 \\
\hline & $(0.000)$ & $(0.000)$ & $(0.000)$ & $(0.000)$ & $(0.000)$ & $(0.000)$ & $(0.000)$ & $(0.000)$ & $(0.000)$ & $(0.000)$ \\
\hline & - & - & - & - & - & & & & - & - \\
\hline \multirow[t]{2}{*}{ _hatsq } & .0326594 & .0343865 & .0306066 & .0347055 & .0278007 & -.0212765 & -.013806 & -.0338271 & .0254741 & .0325116 \\
\hline & $(0.055)$ & $(0.047)$ & $(0.072)$ & $(0.043)$ & 0.120 & 0.379 & 0.544 & 0.220 & 0.122 & 0.067 \\
\hline
\end{tabular}

zárójelben

Forrás: saját számitás European Commission (2012c) alapján 
5.6. melléklet

A migrációs hajlandóságot meghatározó tényezők az EU állampolgárai körében

(2008). Az (II.1.1) specifikációjú logit modell marginális hatásai

\begin{tabular}{|c|c|c|}
\hline & \multicolumn{2}{|c|}{ (II.1.1) } \\
\hline Hálózat_tapasztalat & $0.0514 * * *$ & $(0.00621)$ \\
\hline Internet & $0.00417 * * *$ & $(0.00145)$ \\
\hline Nyelv1 & $0.00651 * * *$ & $(0.00159)$ \\
\hline Nyelv2 & $0.00518 * * *$ & $(0.00130)$ \\
\hline Ingatlan & -0.000892 & $(0.00138)$ \\
\hline Parnerrel & $0.00819 * * *$ & $(0.00289)$ \\
\hline Egyedülálló & $0.0115^{* * *}$ & $(0.00301)$ \\
\hline Elvált & $0.0148 * * *$ & $(0.00391)$ \\
\hline Özvegy & 0.00426 & $(0.00525)$ \\
\hline Gyermek & $-0.00152 * *$ & $(0.000751)$ \\
\hline Nem & $0.00533 * * *$ & $(0.00127)$ \\
\hline Kor & $-0.000705 * * *$ & $(7.34 \mathrm{e}-05)$ \\
\hline Falu & $-0.00768 * * *$ & $(0.00142)$ \\
\hline Kisváros & $-0.00294 * *$ & $(0.00133)$ \\
\hline Iskola & $0.000372 * * *$ & $(0.000116)$ \\
\hline Önfoglalkoztató & $0.0119 * * *$ & $(0.00381)$ \\
\hline Foglalkoztatott_kékgalléros & 0.00228 & $(0.00194)$ \\
\hline Munkanélküli & $0.0115 * * *$ & $(0.00321)$ \\
\hline Nyugdíjas & -0.00243 & $(0.00302)$ \\
\hline Tanuló & $0.0157 * * *$ & $(0.00379)$ \\
\hline Bizalom_általános & $-0.0118 * * *$ & $(0.00190)$ \\
\hline Intézmény_informális & $-0.00519 * * *$ & $(0.00126)$ \\
\hline Belgium & $-0.00651 * * *$ & $(0.00219)$ \\
\hline Hollandia & $-0.00619 * *$ & $(0.00261)$ \\
\hline Németország (volt NSZK) & $-0.0101 * * *$ & $(0.00180)$ \\
\hline Olaszország & $-0.0130 * * *$ & $(0.00148)$ \\
\hline Luxemburg & $-0.00657 * *$ & $(0.00292)$ \\
\hline Dánia & $-0.00565 * *$ & $(0.00235)$ \\
\hline Írország & $-0.00502 * *$ & $(0.00256)$ \\
\hline Nagy-Britannia & -0.000822 & $(0.00343)$ \\
\hline Észak-Írország & -0.00487 & $(0.00409)$ \\
\hline Görögország & $-0.00816^{* * *}$ & $(0.00193)$ \\
\hline Spanyolország & $-0.0143 * * *$ & $(0.00126)$ \\
\hline Portugália & $-0.00668 * * *$ & $(0.00239)$ \\
\hline Németország (volt NDK) & $-0.0120 * * *$ & $(0.00171)$ \\
\hline Finnország & -0.00418 & $(0.00280)$ \\
\hline Svédország & 0.000394 & $(0.00354)$ \\
\hline Ausztria & $-0.0127 * * *$ & $(0.00156)$ \\
\hline Ciprus & $-0.00797 * * *$ & $(0.00302)$ \\
\hline Csehország & $-0.0129 * * *$ & $(0.00152)$ \\
\hline Észtország & -0.00240 & $(0.00297)$ \\
\hline Magyarország & -0.00455 & $(0.00298)$ \\
\hline Lettország & 0.000412 & $(0.00325)$ \\
\hline Litvánia & $-0.00502 * *$ & $(0.00249)$ \\
\hline Málta & -0.00491 & $(0.00404)$ \\
\hline Lengyelország & $-0.0117 * * *$ & $(0.00156)$ \\
\hline Szlovákia & $-0.00915 * * *$ & $(0.00213)$ \\
\hline Szlovénia & $-0.0119 * * *$ & $(0.00156)$ \\
\hline
\end{tabular}




$$
\begin{array}{lcc}
\text { Bulgária } & -0.00429 & (0.00280) \\
\text { Románia } & -0.00775 * * * & (0.00218) \\
\mathrm{N} & 20,618 \\
\text { Pszeudo R-négyzet } & 0.236 \\
\hline \text { Robusztus standard hibák zárójelben. } \\
\text { *** } \mathrm{p}<0.01, * * \mathrm{p}<0.05, * \mathrm{p}<0.1 \\
\text { Referenciacsoportokat meghatározó változók: Házas, Nagyváros, } \\
\text { Foglalkoztatott_fehérgalléros, Franciaország. }
\end{array}
$$

\begin{tabular}{|c|c|c|c|}
\hline $\begin{array}{l}\text { Korlátozott modell } \\
\text { Teljes modell }\end{array}$ & $\begin{array}{l}\text { (III) } \\
\text { specifikáció } \\
\text { (IV) } \\
\text { specifikáció }\end{array}$ & $\begin{array}{l}\text { (III) specifikáció } \\
\text { (IV.3) } \\
\text { specifikáció }\end{array}$ & $\begin{array}{l}\text { (IV) specifikáció } \\
\text { (IV.4) } \\
\text { specifikáció }\end{array}$ \\
\hline LR & 404,86 & 2778,41 & 468,63 \\
\hline Prob $>$ chi 2 & 0,0000 & 0,0000 & 0,0000 \\
\hline
\end{tabular}

Forrás: saját számítás European Commission (2012c) alapján

5.7. melléklet

\section{Likelihood ratio tesztek eredményei a második vizsgálatban}

Forrás: saját számitás European Commission (2012d) alapján

\section{8. melléklet}

\section{A likelihood ratio khí négyzet próbák (G teszt) eredményei a második vizsgálatban}

\begin{tabular}{lrrrrrrr} 
& \multicolumn{1}{c}{ (III) } & \multicolumn{1}{c}{ (IV) } & \multicolumn{1}{c}{ (III.1) } & \multicolumn{1}{c}{ (III.2) } & \multicolumn{1}{c}{ (IV.1) } & \multicolumn{1}{c}{ (IV.2) } & \multicolumn{1}{c}{ (IV.3) } \\
\hline Log-Lik Intercept Only: & $-8530,854$ & $-8492,243$ & $-8495,926$ & $-8338,51$ & $-8455,28$ & $-8300,614$ & $-6850,168$ \\
Log-Lik Full Model: & $-6316,341$ & $-6113,909$ & $-6357,66$ & $-6196,098$ & $-6151,159$ & $-5998,444$ & $-4927,137$ \\
D(24162): & 12632,682 & 12227,819 & 12715,32 & 12392,195 & 12302,319 & 11996,888 & 9854,275 \\
LR(20): & 4429,026 & 4756,668 & 4276,532 & 4284,826 & 4608,241 & 4604,34 & 3846,061 \\
Prob > LR: & 0,000 & 0,000 & 0,000 & 0,000 & 0,000 & 0,000 & 0,000
\end{tabular}

Forrás: saját számitás European Commission (2012d) alapján

\section{9. melléklet}

\section{A Hosmer-Lemeshow tesztek eredményei a második vizsgálatban}

\begin{tabular}{lrrrrrrrr} 
& (III) & \multicolumn{1}{c}{ (IV) } & (III.1) & (III.2) & (IV.1) & (IV.2) & (IV.3) & (IV.4) \\
\hline Hosmer-Lemeshow chi2(2) & 2,63 & 4,18 & 4,12 & 1,83 & 7,89 & 5,08 & 3,09 & 5,39 \\
Prob > chi2 & 0,2688 & 0,1238 & 0,1277 & 0,4009 & 0,0194 & 0,0789 & 0,2137 & 0,0675
\end{tabular}

Forrás: saját számítás European Commission (2012d) alapján 


\subsection{0. mellékletben}

\section{A link teszt eredményei a második vizsgálatban}

\begin{tabular}{lllllllll} 
& \multicolumn{1}{c}{$(\mathrm{III})$} & \multicolumn{1}{c}{$(\mathrm{IV})$} & \multicolumn{1}{c}{$(\mathrm{III} .1)$} & \multicolumn{1}{c}{$(\mathrm{III} .2)$} & \multicolumn{1}{c}{$(\mathrm{IV} .1)$} & \multicolumn{1}{c}{ (IV.2) } & \multicolumn{1}{c}{$(\mathrm{IV} .3)$} & \multicolumn{1}{c}{$(\mathrm{IV} .4)$} \\
\hline \multirow{2}{*}{ hat } & .9632047 & .9541524 & .9450829 & .9571471 & .9370503 & .9482883 & .9321647 & 1.003957 \\
& $(0.000)$ & $(0.000)$ & $(0.000)$ & $(0.000)$ & $(0.000)$ & $(0.000)$ & $(0.000)$ & $(0.000)$ \\
& - & - & - & - & - & & - & \\
_hatsq & .0109567 & .0140434 & .0162866 & .0127592 & .0192196 & -.01584 & .0210839 & .0012328 \\
& $(0.314)$ & $(0.169)$ & $(0.151)$ & $(0.251)$ & $(0.070)$ & $(0.129)$ & $(0.065)$ & $(0.894)$
\end{tabular}

p értékek zárójelben

Forrás: saját számítás European Commission (2012d) alapján

\subsection{1. melléklet}

\section{A VIF mutatók értékei a második vizsgálat specifikációiban ${ }^{104}$}

\begin{tabular}{|c|c|c|c|c|c|c|c|c|}
\hline \multicolumn{3}{|c|}{ (III) } & \multicolumn{3}{|c|}{ (IV) } & \multicolumn{3}{|c|}{ (III.1) } \\
\hline Variable & VIF & $1 / \mathrm{VIF}$ & Variable & VIF & $1 / \mathrm{VIF}$ & Variable & VIF & $1 / \mathrm{VIF}$ \\
\hline kor & 16.78 & 0.059598 & hüség & 36.51 & 0.027390 & kor & 18.75 & 0.053340 \\
\hline iskola & 14.42 & 0.069362 & település & 25.64 & 0.039005 & iskola & 15.65 & 0.063914 \\
\hline internet 2 & 4.56 & 0.219323 & kor & 22.66 & 0.044133 & státusz & 13.03 & 0.076731 \\
\hline ingatlan & 4.49 & 0.222576 & iskola & 16.03 & 0.062386 & internet 2 & 4.83 & 0.206985 \\
\hline nyugdijas & 4.21 & 0.237588 & ingatlan & 4.66 & 0.214414 & ingatlan & 4.59 & 0.218002 \\
\hline nyelv & 2.40 & 0.417527 & internet 2 & 4.64 & 0.215383 & nyugdijas & 4.22 & 0.237021 \\
\hline hálób & 2.37 & 0.422693 & nyugdijas & 4.21 & 0.237512 & nyelv & 2.39 & 0.417999 \\
\hline város 1 & 2.35 & 0.425214 & nyelv & 2.40 & 0.416763 & város 1 & 2.36 & 0.424061 \\
\hline város2 & 2.25 & 0.443701 & város1 & 2.37 & 0.421436 & hálób & 2.35 & 0.424843 \\
\hline nem & 1.98 & 0.504253 & hálób & 2.37 & 0.422258 & város2 & 2.26 & 0.442795 \\
\hline munkanelkuli & 1.87 & 0.533716 & város2 & 2.27 & 0.440797 & nem & 1.98 & 0.504094 \\
\hline foglalkoz kg & 1.85 & 0.539218 & nem & 1.99 & 0.502989 & csalad3 & 1.83 & 0.546541 \\
\hline csalad3 & 1.80 & 0.554624 & munkanelkuli & 1.92 & 0.520541 & foglalkoz $\sim \mathrm{kg}$ & 1.83 & 0.547891 \\
\hline hálór & 1.79 & 0.559773 & foglalkoz $\sim \mathrm{kg}$ & 1.91 & 0.523385 & munkanelkuli & 1.78 & 0.560460 \\
\hline hálóé & 1.74 & 0.573200 & csalad3 & 1.86 & 0.537090 & hálór & 1.77 & 0.563612 \\
\hline anyagi_ & 1.65 & 0.605865 & hálór & 1.79 & 0.558672 & hálóé & 1.74 & 0.574236 \\
\hline hálót & 1.63 & 0.614012 & hálóé & 1.75 & 0.572786 & tanulo & 1.66 & 0.603758 \\
\hline hálód & 1.62 & 0.615561 & anyagi_ & 1.70 & 0.589921 & hálót & 1.62 & 0.616434 \\
\hline tanulo & 1.61 & 0.620877 & tanulo & 1.68 & 0.596468 & hálód & 1.62 & 0.618597 \\
\hline gyerek & 1.50 & 0.665838 & hálót & 1.63 & 0.613679 & gyerek & 1.50 & 0.668165 \\
\hline hálój & 1.49 & 0.671733 & hálód & 1.62 & 0.615535 & hálój & 1.48 & 0.677113 \\
\hline csalad5 & 1.42 & 0.704794 & gyerek & 1.54 & 0.648684 & csalad5 & 1.41 & 0.707766 \\
\hline onfoglalko o & 1.36 & 0.736196 & hálój & 1.49 & 0.670204 & onfoglalko o & 1.36 & 0.737159 \\
\hline csalad2 & 1.24 & 0.807105 & csalad5 & 1.42 & 0.704609 & csalad2 & 1.24 & 0.805697 \\
\hline csalad4 & 1.18 & 0.848466 & onfoglalko o & 1.37 & 0.729991 & csalad4 & 1.16 & 0.859357 \\
\hline & & & csalad 2 & 1.26 & 0.794879 & & & \\
\hline Mean VIF & 3.18 & & csalad4 & 1.18 & 0.847189 & Mean VIF & 3.78 & \\
\hline & & & Mean VIF & 5.55 & & & & \\
\hline
\end{tabular}

\footnotetext{
${ }^{104}$ A táblázatban szereplő o1,02,..,o29 ország dummyk rendre a következő országokra utalnak: Belgium, Hollandia, Németország (volt NSZK), Olaszország, Luxemburg, Dánia, Írország, Nagy-Britannia, ÉszakÍrország, Görögország, Spanyolország, Portugália, Németország (volt NDK), Finnország, Svédország, Ausztria, Ciprus, Csehország, Észtország, Magyarország, Lettország, Litvánia, Málta, Lengyelország, Szlovákia, Szlovénia, Bulgária, Románia.
} 


\begin{tabular}{|c|c|c|c|c|c|c|c|c|}
\hline \multicolumn{3}{|c|}{ (III.2) } & \multicolumn{3}{|c|}{ (IV.1) } & \multicolumn{3}{|c|}{ (IV.2) } \\
\hline Variable & VIF & $1 / \mathrm{VIF}$ & Variable & VIF & $1 / \mathrm{VIF}$ & Variable & VIF & $1 / \mathrm{VIF}$ \\
\hline kor & 19.07 & 0.052440 & hüség & 36.81 & 0.027168 & hüség & 37.07 & 0.026979 \\
\hline iskola & 15.75 & 0.063495 & település & 25.64 & 0.039001 & település & 25.82 & 0.038725 \\
\hline státusz & 13.52 & 0.073992 & kor & 23.45 & 0.042644 & kor & 23.51 & 0.042531 \\
\hline internet 2 & 4.84 & 0.206571 & iskola & 16.82 & 0.059465 & iskola & 16.80 & 0.059507 \\
\hline ingatlan & 4.61 & 0.216695 & státusz & 13.67 & 0.073151 & státusz & 14.44 & 0.069271 \\
\hline nyugdijas & 4.22 & 0.236798 & internet 2 & 4.86 & 0.205756 & internet 2 & 4.88 & 0.205075 \\
\hline nyelv & 2.40 & 0.416873 & ingatlan & 4.72 & 0.212042 & ingatlan & 4.74 & 0.210846 \\
\hline város 1 & 2.37 & 0.422100 & nyugdijas & 4.22 & 0.237046 & nyugdijas & 4.22 & 0.236894 \\
\hline hálób & 2.36 & 0.423506 & nyelv & 2.40 & 0.416978 & nyelv & 2.40 & 0.415801 \\
\hline város2 & 2.27 & 0.441161 & város1 & 2.37 & 0.421272 & város1 & 2.38 & 0.419580 \\
\hline nem & 1.99 & 0.503225 & hálób & 2.36 & 0.424320 & hálób & 2.36 & 0.423253 \\
\hline munkanelkuli & 1.87 & 0.534334 & város2 & 2.27 & 0.440211 & város2 & 2.28 & 0.438914 \\
\hline foglalkoz kg & 1.86 & 0.538131 & nem & 1.99 & 0.502998 & nem & 1.99 & 0.502402 \\
\hline csalad3 & 1.83 & 0.547044 & foglalkoz $\sim \mathrm{kg}$ & 1.89 & 0.528268 & munkanelkuli & 1.91 & 0.522457 \\
\hline hálór & 1.78 & 0.561197 & csalad3 & 1.89 & 0.529874 & foglalkoz $\sim \mathrm{kg}$ & 1.91 & 0.523831 \\
\hline hálóé & 1.75 & 0.573057 & munkanelkuli & 1.86 & 0.538285 & csalad3 & 1.87 & 0.534175 \\
\hline anyagi_ & 1.70 & 0.587000 & hálór & 1.78 & 0.561717 & hálór & 1.79 & 0.560018 \\
\hline tanulo & 1.64 & 0.611066 & hálóé & 1.74 & 0.573830 & anyagi_ & 1.78 & 0.561610 \\
\hline hálót & 1.63 & 0.615029 & tanulo & 1.72 & 0.582230 & hálóé & 1.75 & 0.572745 \\
\hline hálód & 1.62 & 0.616727 & hálót & 1.62 & 0.616117 & tanulo & 1.69 & 0.593109 \\
\hline gyerek & 1.52 & 0.657317 & hálód & 1.62 & 0.618405 & hálót & 1.63 & 0.614722 \\
\hline hálój & 1.49 & 0.670416 & gyerek & 1.54 & 0.650956 & hálód & 1.62 & 0.616678 \\
\hline csalad5 & 1.42 & 0.706700 & hálój & 1.49 & 0.673247 & gyerek & 1.55 & 0.644735 \\
\hline onfoglalko o & 1.37 & 0.732354 & csalad5 & 1.41 & 0.707339 & hálój & 1.50 & 0.668035 \\
\hline csalad2 & 1.25 & 0.801448 & onfoglalko o & 1.37 & 0.731573 & csalad5 & 1.42 & 0.706461 \\
\hline csalad4 & 1.18 & 0.848534 & csalad2 & 1.26 & 0.793465 & onfoglalko o & 1.37 & 0.728549 \\
\hline & & & csalad4 & 1.17 & 0.856383 & csalad2 & 1.26 & 0.791839 \\
\hline Mean VIF & 3.74 & & & & & csalad4 & 1.18 & 0.847258 \\
\hline & & & Mean VIF & 6.07 & & & & \\
\hline & & & & & & Mean VIF & 5.97 & \\
\hline
\end{tabular}

\begin{tabular}{|c|c|c|c|c|c|}
\hline \multicolumn{3}{|c|}{ (IV.3) } & \multicolumn{3}{|c|}{ (IV.4) } \\
\hline Variable & VIF & 1/VIF & Variable & VIF & $1 / \mathrm{VIF}$ \\
\hline hüség & 36.95 & 0.027067 & hüség & 39.37 & 0.025400 \\
\hline település & 25.29 & 0.039535 & település & 27.78 & 0.035997 \\
\hline kor & 23.13 & 0.043236 & kor & 25.17 & 0.039725 \\
\hline iskola & 15.92 & 0.062818 & iskola & 17.94 & 0.055749 \\
\hline internet 2 & 4.92 & 0.203363 & ingatlan & 5.08 & 0.196896 \\
\hline ingatlan & 4.79 & 0.208551 & internet 2 & 4.98 & 0.200842 \\
\hline nyugdijas & 4.16 & 0.240122 & nyugdijas & 4.30 & 0.232406 \\
\hline nyelv & 2.44 & 0.409346 & nyelv & 2.98 & 0.336054 \\
\hline hálób & 2.36 & 0.423231 & város1 & 2.48 & 0.402901 \\
\hline város1 & 2.34 & 0.427390 & hálób & 2.43 & 0.411404 \\
\hline város2 & 2.28 & 0.438739 & város2 & 2.39 & 0.418795 \\
\hline nem & 2.01 & 0.498704 & o7 & 2.07 & 0.482368 \\
\hline foglalkoz kg & 1.87 & 0.533352 & o16 & 2.06 & 0.485047 \\
\hline csalad3 & 1.87 & 0.533805 & nem & 2.00 & 0.499634 \\
\hline munkanelkuli & 1.85 & 0.540159 & munkanelkuli & 1.99 & 0.502716 \\
\hline hálór & 1.77 & 0.565109 & o23 & 1.96 & 0.510199 \\
\hline
\end{tabular}




\begin{tabular}{|c|c|c|c|c|c|}
\hline hálóé & 1.72 & 0.580388 & o11 & 1.96 & 0.510341 \\
\hline tanulo & 1.70 & 0.587744 & anyagi_ & 1.95 & 0.511965 \\
\hline anyagi_ & 1.67 & 0.599953 & o15 & 1.95 & 0.513041 \\
\hline hálód & 1.61 & 0.621000 & foglalkoz $\sim \mathrm{kg}$ & 1.94 & 0.514224 \\
\hline hálót & 1.60 & 0.624406 & o20 & 1.94 & 0.515055 \\
\hline gyerek & 1.54 & 0.648300 & csalad3 & 1.93 & 0.518867 \\
\hline hálój & 1.50 & 0.667367 & o22 & 1.92 & 0.521817 \\
\hline csalad5 & 1.41 & 0.709535 & o27 & 1.91 & 0.522237 \\
\hline onfoglalko o & 1.35 & 0.738389 & o21 & 1.90 & 0.525295 \\
\hline csalad2 & 1.27 & 0.790274 & o3 & 1.90 & 0.526668 \\
\hline kisebbség & 1.19 & 0.840988 & o8 & 1.90 & 0.527495 \\
\hline \multirow[t]{2}{*}{ csalad4 } & 1.18 & 0.850550 & hálór & 1.87 & 0.533632 \\
\hline & & & o26 & 1.87 & 0.534532 \\
\hline \multirow[t]{27}{*}{ Mean VIF } & 5.42 & & o12 & 1.85 & 0.539823 \\
\hline & & & o9 & 1.84 & 0.542029 \\
\hline & & & o5 & 1.84 & 0.543239 \\
\hline & & & o25 & 1.82 & 0.548558 \\
\hline & & & o17 & 1.82 & 0.549289 \\
\hline & & & o4 & 1.81 & 0.552185 \\
\hline & & & o28 & 1.80 & 0.554693 \\
\hline & & & o2 & 1.78 & 0.562869 \\
\hline & & & hálóé & 1.75 & 0.570032 \\
\hline & & & o13 & 1.75 & 0.570228 \\
\hline & & & o19 & 1.75 & 0.570722 \\
\hline & & & hálój & 1.73 & 0.576569 \\
\hline & & & o29 & 1.72 & 0.581444 \\
\hline & & & tanulo & 1.71 & 0.585627 \\
\hline & & & hálót & 1.69 & 0.590573 \\
\hline & & & hálód & 1.64 & 0.608181 \\
\hline & & & gyerek & 1.57 & 0.638057 \\
\hline & & & 06 & 1.56 & 0.641062 \\
\hline & & & o18 & 1.51 & 0.663894 \\
\hline & & & o24 & 1.50 & 0.665128 \\
\hline & & & csalad5 & 1.43 & 0.699138 \\
\hline & & & o14 & 1.40 & 0.713579 \\
\hline & & & onfoglalko o & 1.39 & 0.717266 \\
\hline & & & csalad2 & 1.29 & 0.775637 \\
\hline & & & o10 & 1.25 & 0.800555 \\
\hline & & & csalad4 & 1.20 & 0.836517 \\
\hline & & & Mean VIF & 3.86 & \\
\hline
\end{tabular}

Forrás: saját számitás European Commission (2012d) alapján 
A migrációs hajlandóságot meghatározó tényezők az EU állampolgárai körében (2010). A (IV.4) specifikációjú logit modell marginális hatásai

\begin{tabular}{|c|c|c|}
\hline & \multicolumn{2}{|c|}{ (IV.4) } \\
\hline Hálózat_rokon & $0.0148 * * *$ & $(0.00254)$ \\
\hline Hálózat_barát & $0.0344 * * *$ & $(0.00274)$ \\
\hline Hálózat_munka & $0.0321 * * *$ & $(0.00429)$ \\
\hline Hálózat_iskola & $0.0140 * * *$ & $(0.00436)$ \\
\hline Hálózat_élet & $0.0235 * * *$ & $(0.00452)$ \\
\hline Hálózat_szabadság & $0.0241 * * *$ & $(0.00352)$ \\
\hline Internet & $0.00295 * * *$ & $(0.000558)$ \\
\hline Nyelv & $0.00910 * * *$ & $(0.00264)$ \\
\hline Ingatlan & $-0.0108 * * *$ & $(0.00263)$ \\
\hline Partnerrel & $0.0109 * * *$ & $(0.00401)$ \\
\hline Egyedülálló & $0.0210 * * *$ & $(0.00394)$ \\
\hline Elvált & $0.0133 * *$ & $(0.00518)$ \\
\hline Özvegy & 0.00613 & $(0.00755)$ \\
\hline Gyermek & $-0.00689 * * *$ & $(0.00125)$ \\
\hline Nem & $0.00683 * * *$ & $(0.00213)$ \\
\hline Kor & $-0.00166 * * *$ & $(0.000118)$ \\
\hline Falu & $-0.00923 * * *$ & $(0.00254)$ \\
\hline Kisváros & -0.00217 & $(0.00244)$ \\
\hline Iskola & $0.000512 * *$ & $(0.000233)$ \\
\hline Önfoglalkoztató & 0.00711 & $(0.00470)$ \\
\hline Foglalkoztatott & $0.00624 *$ & $(0.00336)$ \\
\hline Munkanélküli & $0.0121 * * *$ & $(0.00384)$ \\
\hline Nyugdíjas & $-0.0146 * * *$ & $(0.00426)$ \\
\hline Tanuló & $0.0467 * * *$ & $(0.00721)$ \\
\hline Anyagi & $0.0114 * * *$ & $(0.00170)$ \\
\hline Hüség_ország & $-0.0217 * * *$ & $(0.00172)$ \\
\hline Hüség_település & $-0.0111 * * *$ & $(0.00144)$ \\
\hline Belgium & $-0.0129 * *$ & $(0.00524)$ \\
\hline Hollandia & $-0.0297 * * *$ & $(0.00296)$ \\
\hline Németország (volt NSZK) & $-0.0251 * * *$ & $(0.00374)$ \\
\hline Olaszország & $-0.0162 * * *$ & $(0.00539)$ \\
\hline Luxemburg & $-0.0132 * *$ & $(0.00575)$ \\
\hline Dánia & 0.00509 & $(0.00714)$ \\
\hline Írország & -0.00520 & $(0.00592)$ \\
\hline Nagy-Britannia & 0.00302 & $(0.00724)$ \\
\hline Észak-Írország & -0.0114 & $(0.00741)$ \\
\hline Görögország & $-0.0183 * * *$ & $(0.00493)$ \\
\hline Spanyolország & -0.00613 & $(0.00608)$ \\
\hline Portugália & $-0.0112 * *$ & $(0.00566)$ \\
\hline Németország (volt NDK) & $-0.0271 * * *$ & $(0.00428)$ \\
\hline Finnország & $-0.0132 * *$ & $(0.00566)$ \\
\hline Svédország & -0.00617 & $(0.00595)$ \\
\hline Ausztria & $-0.0252 * * *$ & $(0.00387)$ \\
\hline Ciprus & 0.000628 & $(0.00827)$ \\
\hline Csehország & $-0.0335 * * *$ & $(0.00286)$ \\
\hline Észtország & -0.00128 & $(0.00650)$ \\
\hline Magyarország & $-0.0137 * *$ & $(0.00540)$ \\
\hline
\end{tabular}




\begin{tabular}{|c|c|c|}
\hline Lettország & $0.0828 * * *$ & $(0.0158)$ \\
\hline Litvánia & $0.0312 * * *$ & $(0.0100)$ \\
\hline Málta & $-0.0121 *$ & $(0.00660)$ \\
\hline Lengyelország & -0.00834 & $(0.00642)$ \\
\hline Szlovákia & $-0.0222 * * *$ & $(0.00408)$ \\
\hline Szlovénia & $-0.0246 * * *$ & $(0.00384)$ \\
\hline Bulgária & -0.00789 & $(0.00660)$ \\
\hline Románia & $-0.0103^{*}$ & $(0.00626)$ \\
\hline $\mathrm{N}$ & \multicolumn{2}{|c|}{24,239} \\
\hline Pszeudo R-négyzet & \multicolumn{2}{|c|}{0.308} \\
\hline $\begin{array}{l}\text { Robusztus standard hibák zárójelben. } \\
* * * \mathrm{p}<0.01, * * \mathrm{p}<0.05, * \mathrm{p}<0.1\end{array}$ & & \\
\hline Referenciacsoportokat meghatározó & változók: & Házas, \\
\hline
\end{tabular}

Forrás: saját számítás European Commission (2012d) alapján

\subsection{3. melléklet}

A migrációs hajlandóságot meghatározó tényezők az EU állampolgárai körében (2010). A (IV) specifikációjú rendezett (ordered) logit modell marginális hatásai az eredményváltozó különböző kimenetei szerint

\begin{tabular}{|c|c|c|c|c|}
\hline & $\begin{array}{c}\operatorname{mmigr}^{\wedge} 2010= \\
0\end{array}$ & $\begin{array}{c}\operatorname{mmigr}^{\wedge} 2010= \\
1\end{array}$ & $\begin{array}{c}\operatorname{mmigr}^{\wedge} 2010= \\
2\end{array}$ & $\begin{array}{c}\operatorname{mmigr}^{\wedge} 2010= \\
3\end{array}$ \\
\hline \multirow[t]{2}{*}{ Hálózat_rokon } & $-0.0569 * * *$ & $0.0417 * * *$ & $0.0120 * * *$ & $0.00315 * * *$ \\
\hline & $(0.00666)$ & $(0.00485)$ & $(0.00147)$ & $(0.000401)$ \\
\hline \multirow[t]{2}{*}{ Hálózat_barát } & $-0.117 * * *$ & $0.0856^{* * *}$ & $0.0248 * * *$ & $0.00650 * * *$ \\
\hline & $(0.00626)$ & $(0.00459)$ & $(0.00148)$ & $(0.000443)$ \\
\hline \multirow[t]{2}{*}{ Hálózat_munka } & $-0.0893 * * *$ & $0.0642 * * *$ & $0.0198 * * *$ & $0.00525 * * *$ \\
\hline & $(0.00981)$ & $(0.00688)$ & $(0.00237)$ & $(0.000657)$ \\
\hline \multirow[t]{2}{*}{ Hálózat_iskola } & $-0.0337 * * *$ & $0.0246 * * *$ & $0.00717 * * *$ & $0.00188 * * *$ \\
\hline & $(0.0114)$ & $(0.00822)$ & $(0.00249)$ & $(0.000661)$ \\
\hline \multirow[t]{2}{*}{ Hálózat_élet } & $-0.0822 * * *$ & $0.0592 * * *$ & $0.0182 * * *$ & $0.00484 * * *$ \\
\hline & $(0.0117)$ & $(0.00819)$ & $(0.00280)$ & $(0.000772)$ \\
\hline \multirow[t]{2}{*}{ Hálózat_szabadság } & $-0.0571 * * *$ & $0.0416 * * *$ & $0.0122 * * *$ & $0.00321 * * *$ \\
\hline & $(0.00740)$ & $(0.00533)$ & $(0.00167)$ & $(0.000455)$ \\
\hline \multirow[t]{2}{*}{ Internet } & $-0.0157 * * *$ & $0.0116^{* * *}$ & $0.00324 * * *$ & $0.000843 * * *$ \\
\hline & $(0.00148)$ & $(0.00110)$ & $(0.000312)$ & $(8.65 \mathrm{e}-05)$ \\
\hline \multirow[t]{2}{*}{ Nyelv } & $-0.0763 * * *$ & $0.0561 * * *$ & $0.0160 * * *$ & $0.00418 * * *$ \\
\hline & $(0.00634)$ & $(0.00467)$ & $(0.00138)$ & $(0.000390)$ \\
\hline \multirow[t]{2}{*}{ Ingatlan } & $0.0318^{* * *}$ & $-0.0233 * * *$ & $-0.00669 * * *$ & $-0.00175^{* * *}$ \\
\hline & $(0.00694)$ & $(0.00506)$ & $(0.00150)$ & $(0.000398)$ \\
\hline \multirow[t]{2}{*}{ Partnerrel } & $-0.0476 * * *$ & $0.0346^{* * *}$ & $0.0102 * * *$ & $0.00270 * * *$ \\
\hline & $(0.00992)$ & $(0.00712)$ & $(0.00223)$ & $(0.000599)$ \\
\hline \multirow[t]{2}{*}{ Egyedülálló } & $-0.0610 * * *$ & $0.0444 * * *$ & $0.0131 * * *$ & $0.00346 * * *$ \\
\hline & $(0.00943)$ & $(0.00676)$ & $(0.00214)$ & $(0.000579)$ \\
\hline \multirow[t]{2}{*}{ Elvátl } & $-0.0755^{* * *} *$ & $0.0544 * * *$ & $0.0167 * * *$ & $0.00443 * * *$ \\
\hline & $(0.0129)$ & $(0.00905)$ & $(0.00306)$ & $(0.000843)$ \\
\hline \multirow[t]{2}{*}{ Özvegy } & -0.00490 & 0.00362 & 0.00102 & 0.000266 \\
\hline & $(0.0180)$ & $(0.0133)$ & $(0.00376)$ & $(0.000981)$ \\
\hline Gyermek & $0.0201 * * *$ & $-0.0149 * * *$ & $-0.00417 * * *$ & $-0.00108 * * *$ \\
\hline
\end{tabular}




\begin{tabular}{|c|c|c|c|c|}
\hline & $(0.00329)$ & $(0.00243)$ & $(0.000686)$ & $(0.000182)$ \\
\hline \multirow[t]{2}{*}{ Nem } & $-0.0439 * * *$ & $0.0324 * * *$ & $0.00914 * * *$ & $0.00238 * * *$ \\
\hline & $(0.00582)$ & $(0.00429)$ & $(0.00123)$ & $(0.000331)$ \\
\hline \multirow[t]{2}{*}{ Kor } & $0.00788 * * *$ & $-0.00583 * * *$ & $-0.00163 * * *$ & $-0.000425 * * *$ \\
\hline & $(0.000306)$ & $(0.000235)$ & $(7.09 \mathrm{e}-05)$ & $(2.28 \mathrm{e}-05)$ \\
\hline \multirow[t]{2}{*}{ Falu } & $0.0413 * * *$ & $-0.0306 * * *$ & $-0.00847 * * *$ & $-0.00220 * * *$ \\
\hline & $(0.00691)$ & $(0.00515)$ & $(0.00141)$ & $(0.000374)$ \\
\hline \multirow[t]{2}{*}{ Kisváros } & 0.00469 & -0.00347 & -0.000970 & -0.000252 \\
\hline & $(0.00678)$ & $(0.00501)$ & $(0.00140)$ & $(0.000364)$ \\
\hline \multirow[t]{2}{*}{ Iskola } & $-0.00509 * * *$ & $0.00376 * * *$ & $0.00105 * * *$ & $0.000274 * * *$ \\
\hline & $(0.000613)$ & $(0.000456)$ & $(0.000128)$ & $(3.43 \mathrm{e}-05)$ \\
\hline \multirow{2}{*}{ Önfoglalkoztató } & -0.0168 & 0.0123 & 0.00352 & 0.000919 \\
\hline & $(0.0112)$ & $(0.00816)$ & $(0.00238)$ & $(0.000625)$ \\
\hline \multirow[t]{2}{*}{ Foglalkoztatott_kékgalléros } & -0.00439 & 0.00324 & 0.000912 & 0.000237 \\
\hline & $(0.00821)$ & $(0.00606)$ & $(0.00171)$ & $(0.000446)$ \\
\hline \multirow[t]{2}{*}{ Munkanélküli } & $-0.0187 * *$ & $0.0137 * *$ & $0.00392 *$ & $0.00102 *$ \\
\hline & $(0.00946)$ & $(0.00692)$ & $(0.00201)$ & $(0.000529)$ \\
\hline \multirow[t]{2}{*}{ Nyugdíjas } & $0.0759 * * *$ & $-0.0566 * * *$ & $-0.0153 * * *$ & $-0.00396 * * *$ \\
\hline & $(0.0107)$ & $(0.00806)$ & $(0.00213)$ & $(0.000565)$ \\
\hline \multirow[t]{2}{*}{ Tanuló } & $-0.0979 * * *$ & $0.0699 * * *$ & $0.0221 * * *$ & $0.00592 * * *$ \\
\hline & $(0.0138)$ & $(0.00944)$ & $(0.00345)$ & $(0.000955)$ \\
\hline \multirow[t]{2}{*}{ Anyagi } & $-0.0469 * * *$ & $0.0347 * * *$ & $0.00972 * * *$ & $0.00253 * * *$ \\
\hline & $(0.00468)$ & $(0.00347)$ & $(0.000992)$ & $(0.000272)$ \\
\hline \multirow[t]{2}{*}{ Hüség_ország } & $0.0693^{* * *}$ & $-0.0512 * * *$ & $-0.0143 * * *$ & $-0.00373 * * *$ \\
\hline & $(0.00479)$ & $(0.00358)$ & $(0.00104)$ & $(0.000291)$ \\
\hline \multirow[t]{2}{*}{ Hüség_település } & $0.0384 * * *$ & $-0.0284 * * *$ & $-0.00795 * * *$ & $-0.00207 * * *$ \\
\hline & $(0.00407)$ & $(0.00303)$ & $(0.000862)$ & $(0.000232)$ \\
\hline $\mathrm{N}$ & 24,239 & 24,239 & 24,239 & 24,239 \\
\hline Pszeudo R-négyzet & 0.217 & 0.217 & 0.217 & 0.217 \\
\hline
\end{tabular}

Robusztus standard hibák zárójelben.

$* * * \mathrm{p}<0.01, * * \mathrm{p}<0.05, * \mathrm{p}<0.1$

Referenciacsoportokat meghatározó változók: Házas, Nagyváros, Foglalkoztatott_fehérgalléros.

Forrás: saját számitás European Commission (2012d) alapján

\subsection{4. melléklet}

\section{A (IV) specifikációjú rendezett logit modell becsült eredményváltozóinak}

\section{átlagainak összevetése az eredményváltozó valódi értékeinek gyakoriságaival}

\begin{tabular}{lcccrl}
\multicolumn{1}{c}{$\begin{array}{c}\text { Becsült } \\
\text { eredményváltozó }\end{array}$} & Átlag & & $\begin{array}{c}\text { mmigr^2010 } \\
\text { értékei }\end{array}$ & Gyakoriság & Részarány \\
\cline { 2 - 2 } \cline { 4 - 5 } p0ologit & .6836156 & & & 17,786 & 68.46 \\
p1ologit & .2017277 & & 1 & 5,188 & 19.97 \\
p2ologit & .0834076 & & 2 & 2,179 & 8.39 \\
p3ologit & .0312491 & & 3 & 826 & 3.18
\end{tabular}

Forrás: saját számitás European Commission (2012d) alapján 


\section{PUBLIKÁCIÓS LISTA}

\section{A témakörrel kapcsolatos saját publikációk}

Tudományos könyv, könyvfejezet (magyar nyelven):

Golovics József (2015). Agyelszívás: egyensúly európai szinten? In Ferencz Árpád, II. Gazdálkodás és menedzsment tudományos konferencia. I. kötet (456-460. o.). Kecskemét: Kecskeméti Főiskola KIK Nyomda.

Golovics József (2015). Az agyelszívási adó relevanciája a XXI. században. In Keresztes Gábor, Tavaszi Szél 2015 Konferenciakötett II. (387-397. o.). Eger: Líceum Kiadó.

Golovics, J. (2018). Elvándorlás a felsőoktatás szemszögéből. Helyzetkép és kormányzati válasz. In Kováts Gergely \& Temesi József, A magyar felsőoktatás egy évtizede. 2008 - 2017 (171-182. o.). Budapest: BCE Nemzetközi Felsőoktatási Kutatások Központja.

Referált szakmai folyóiratcikk (magyar nyelven):

Golovics József (2014). Az európai brain drain és a racionális állam válasza. Polgári Szemle, 10(1-2), 484-499.

Golovics József (2015). A hallgatói szerződések közgazdaságtana. Sugo Szemle, 2(1), 104-111.

Golovics József (2015). Korlátozott racionalitás és altruizmus. Behaviorizmus a közgazdaság-tudományban. Hitelintézeti Szemle, 14(2), 158-172.

Golovics József (2016). Agyelszívási adó az EU-ban: egy lehetséges megoldás? Külgazdaság, 60(11-12), 44-65.

Golovics József (2016). Kivándorlás vagy maradás? A hủség szerepe a migrációs döntésekben. Competitio, 15(2), 3-21.

Golovics József (2018). Intézményi bizalom és elvándorlási hajlandóság. Educatio, 27(4), 660-671. (Megjelenés alatt).

Golovics József (2019). A nemzetközi migráció mozgatórugói: elmélet és empíria. Áttekintés. Demográfia (Megjelenés alatt). 
Referált szakmai folyóiratcikk (angol nyelven):

Golovics, J. (2015). Bounded rationality and altruism: behaviourism in economics. Financial and Economic Review, 14(2), 158-172.

Golovics, J. (2019). Addressing the EU's East-West Brain Drain: Why a Tax Solution Would Be in Vain. New Perspectives, 27(2), 63-85.

Golovics, J. (2019). The role of loyalty in migration intentions: theory and evidence from the EU. Society and Economy. Online first, 1-21. Elérhetö: http://akademiai.com/doi/pdf/10.1556/204.2019.010 (2019.07.18.).

\section{További, nem a témakörrel kapcsolatos publikációk}

Golovics József (2012). Sarkozy elnökségének összefoglalása a kampányban tett ígéretei tükrében: A francia elnök mérlege. EUVI Elemzések, 1-8.

Golovics József (2014). Pénzügyi tudatosság, mint a fenntartható gazdasági fejlődés alapja. Polgári Szemle, 10(3-6.), 455-458.

Golovics József (2014). Ünnepi konferencia Szabó Katalin születésnapja alkalmából. Közgazdasági Szemle, 61(12), 1463-1466.

Golovics József (2015). Hatékony árvízvédelem: központosítás vagy decentralizáció? Economica, 8(3), 105-114.

Golovics József (2015). Szükség van-e államra az árvízvédelemben? Egy jóléti gazdaságtani megközelítés. Köz-Gazdaság, 10(3), 113-125.

Golovics József (2016). Gazdaságpolitikai ütközetek: Nicholas Wapshott: Keynes és Hayek. Az összecsapás, amely meghatározta a modern közgazdaságtant. A nagy válságtól a nagy recesszióig c. könyvéről. Köz-Gazdaság, 11(1), 223-230.

Golovics József (2016). Méltó tisztelgés egy páratlan munkásság előtt: Hámori BalázsRosta Miklós (szerk.): Constraints and Driving Forces in Economic Systems: Studies in Honour of János Kornai. Közgazdasági Szemle, 63(10), 1142-1144.

Golovics, J. (2017). Contemporary Realism in Theory and Practice. The Case of the Ukrainian Crisis. Polgári Szemle, 13(1-3), 362-369.

Golovics József (2017). Horvát euró: vágyakhoz passzoló realitás vagy realitáshoz igazított vágyak? Köz-Gazdaság, 12(1), 163-174. 
Golovics, J. (2018). Market versus Government: A Review. In Földi Péter et al., Közgazdász Doktoranduszok és KutatókIV. Téli Konferenciája : Konferenciakötet (564-572. o.). Budapest: Doktoranduszok Országos Szövetsége.

Veres Pál \& Golovics József (2012). Az állam felsőoktatási szerepvállalása. Ezredvég, 22(5), 99-119.

Veres Pál \& Golovics József (2013). Az állami tulajdon hatékonysága és a tulajdonosi jogosítványok érvényesíthetősége a felsőoktatásban. Felsőoktatási Mühely, 8(1), 99-116.

Veres Pál \& Golovics József (2013). Az állami tulajdon hatékonysága és szükségessége a felsőoktatásban. Polgári Szemle, 9(1-3), 118-139.

Veres Pál \& Golovics József (2015). Kancellári rendszer a magyar felsőoktatásban: Célok, funkciók és szerepek. Polgári Szemle, 11(1-3), 209-221.

Veres Pál \& Golovics József (2016). Új szereplők a magyar felsőoktatásban: Kancellári rendszer és konzisztórium. In Kováts Gergely, A kancellári rendszer bevezetése a magyar felsőoktatásban. Tapasztalatok és várakozások (7-22. o.). Budapest: BCE NFKK. 